University of Louisville

ThinkIR: The University of Louisville's Institutional Repository

Electronic Theses and Dissertations

$5-2009$

\title{
From vice to nice : A case study of Newport, Kentucky's HOPE VI program.
}

Matthew Jude Hanka 1980-

University of Louisville

Follow this and additional works at: https://ir.library.louisville.edu/etd

\section{Recommended Citation}

Hanka, Matthew Jude 1980-, "From vice to nice : A case study of Newport, Kentucky's HOPE VI program." (2009). Electronic Theses and Dissertations. Paper 570.

https://doi.org/10.18297/etd/570

This Doctoral Dissertation is brought to you for free and open access by ThinkIR: The University of Louisville's Institutional Repository. It has been accepted for inclusion in Electronic Theses and Dissertations by an authorized administrator of ThinkIR: The University of Louisville's Institutional Repository. This title appears here courtesy of the author, who has retained all other copyrights. For more information, please contact thinkir@louisville.edu. 


\title{
FROM VICE TO NICE: A CASE STUDY OF NEWPORT, KENTUCKY'S
} HOPE VI PROGRAM

\author{
By \\ Matthew Jude Hanka \\ B.A., The Catholic University of America, 2002 \\ M.A., University of Louisville, 2004 \\ A Dissertation \\ Submitted to the Faculty of the \\ Graduate School of the University of Louisville \\ in Partial Fulfillment of the Requirements \\ for the Degree of
}

Doctor of Philosophy

School of Urban and Public Affairs

University of Louisville

Louisville, Kentucky

May 2009 
Copyright 2009 by Matthew Jude Hanka

All rights reserved 
FROM VICE TO NICE: A CASE STUDY OF NEWPORT, KENTUCKY'S HOPE VI PROGRAM

\author{
By \\ Matthew Jude Hanka \\ B.A., The Catholic University of America, 2002 \\ M.A., University of Louisville, 2004
}

A Dissertation Approved on

April 3, 2009

by the following Dissertation Committee:

Dissertation Director 


\section{DEDICATION}

To Annie, my best friend and partner in life 


\section{ACKNOWLEDGMENTS}

There are many people I would like to thank in writing this dissertation. First, I would like to thank Dr. John Gilderbloom, my committee chair, whose guidance, encouragement, advice, camaraderie, and friendship were invaluable. I also want to thank my other committee members, Dr. Hank Savitch, Dr. Steve Koven, Dr. Dewey Clayton, and Professor Carrie Donald, J.D. for their encouragement, ideas, expertise, guidance, edits, and revisions throughout this whole process. I also want to thank Dr. Dennis Keating, professor and former associate dean of the Maxine Goodman Levin College of Urban Affairs at Cleveland State University, for later joining the committee and providing his ideas, suggestions, and valuable insight. All of their input and contributions were invaluable and I will forever owe them a debt of gratitude.

I would also like to thank former Mayor Tom Guidugli of Newport, Steve Pendrey, Campbell County Judge/Executive, Denise Govan, Mary Kitts, and Sharon Stantzell of Brighton Center, Inc. in Newport; Joseph Condit, Linda Fields, and George Darnell of the Housing Authority of Newport (HAN), Benjamin Campbell of the Campbell County Property Valuation Administrator; Captain Howard Niemeier and Lieutenant Jane Poynter of the Newport Police Department, and Karen Majors of Corporex, Inc. for their assistance. Their comments, expertise, and perspectives are a true asset of this dissertation.

I also want to thank Bob Yoder, Main Street Coordinator for the City of Newport and Michael Whitehead, Licensing and Occupation Administrator for their consultation 
and valuable data for business startups in Newport and for access to archived photographs and postcards of Newport. Special thanks goes to Robin Anderson of the mayor's office, and Emily Jarzen, the city's historic preservation officer, for their information on the East Row Historic District and historic preservation efforts in the city. I also would like to thank Vernon Smith of the Kentucky State Data Center at the University of Louisville for his assistance in data collection for this dissertation, and Michael Price and Martye Scobee of Kentucky Population Research at UofL for their assistance in providing the data for Louisville's 170 census tracts for the regression analysis.

Some of the sections in this dissertation were taken from evaluation reports I worked on (Volume IX and the Final Report) from August 2006 to September 2008 through a HOPE VI evaluation grant from HUD received by Dr. Gilderbloom and the Center for Sustainable Urban Neighborhoods (SUN). Special thanks go to Carrie Beth Lasley, Elizabeth McConnell, and Amy Fox, who worked tirelessly to help me collect and gather data for this dissertation, especially Carrie Beth for her GIS and mapping skills, Erin House for the assistance on the research on historic preservation of Newport, and Josh Ambrosius for his help in the statistical analysis and collaboration on other research projects. I also want to thank Dr. Allan Dittmer for reviewing the manuscript, Dr. Bill Friedlander and Dave Simcox for their advice and wisdom, and Virginia Callan for her excellent edits and assistance with the formatting.

Special thanks goes to my dear friends Tom Quisenberry, Amy Tiu, Prasad Cherian, Sarah Smith, Josh and Jenny Bourgeois, Todd Quire, Marcia CarmichaelMurphy, Amy Fox, Matt Evans, Matt and Shaun McKiernan, Ned Berghausen, Colleen 
English, Mario D’Sa, Lindsay Carter, Jamie Gordon, Charlie Hudson, Kevin Johnson, Kareem Usher, Jerry Reynolds, Cara Stewart, Terry Taylor, Maria Wimsatt, and Gerry Williger for all of their support, and all the helpful graduate students in the School of Urban and Public Affairs at the University of Louisville, including Jeff Osgood, Matin Katirai, Yani Vozos, Jennifer Habig, and Courtney Celasun.

I would like to thank my parents Marvin and Martha Hanka, who have provided me enormous love and support throughout my life in the pursuit of my academic goals and dreams. Many thanks goes to my wife, Annie, whose support, love, caring, and understanding have been priceless in completing this life goal for me. 


\section{ABSTRACT \\ FROM VICE TO NICE: A CASE STUDY OF NEWPORT, KENTUCKY'S HOPE VI PROGRAM}

\section{Matthew Jude Hanka}

April 3, 2009

This dissertation examines the outcomes of the Housing Opportunities for People Everywhere (HOPE VI) program in one American city, Newport, Kentucky. HOPE VI also improved the quality of life and satisfaction of former public housing residents who participated in the Community and Supportive Services (CSS) program, the case management program of HOPE VI. HOPE VI neighborhoods in Newport have experienced higher increases in property values. The site of the old public housing in Newport has been cleared to make way for an $\$ 800$ million- $\$ 1$ billion investment over the next 10-15 years. The development will offer a first-class, mixed use development, including retail, office, condominiums, a hotel, and additional amenities in close proximity to downtown Newport.

The reduction of HOPE VI funding has made this dissertation timely and important in documenting the impact of a federal program like HOPE VI on a small sized city. An increased commitment by the Obama administration and increased funding for HOPE VI is necessary to ensure that homeownership is the best way to ensure livable and sustainable communities and revitalize distressed communities throughout the United States. 


\section{TABLE OF CONTENTS}

PAGE

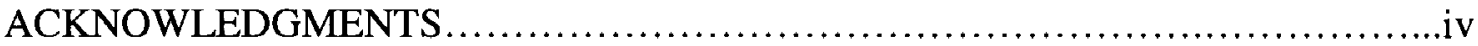

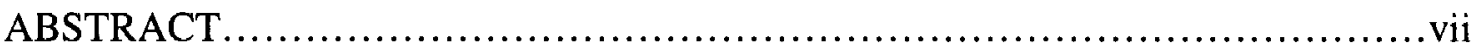

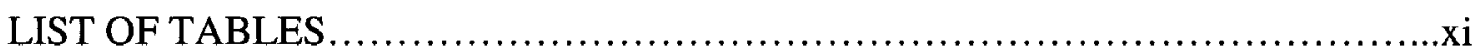

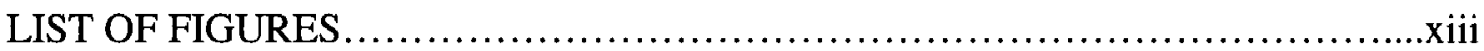

\section{CHAPTER}

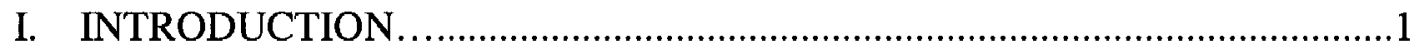

II. REVIEW OF THE LITERATURE.........................................

HOPE VI Impacts..............................................16

Scattered-Site Public Housing ........................................20

Residential Satisfaction...........................................26

HOPE VI Self-Sufficiency Program...............................28

Urban Economic Development.......................................29

III. RESEARCH QUESTION AND METHODOLOGY ...............................

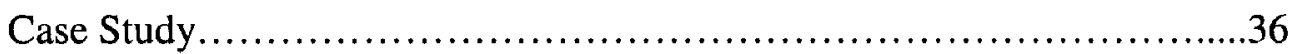

Survey Instrument...........................................

Quantitative Statistical Analysis....................................40

Qualitative Analysis..........................................42

IV. NEWPORT: HOUSING FROM PAST TO PRESENT $\ldots \ldots \ldots \ldots \ldots \ldots \ldots \ldots . . \ldots 44$

Historic Preservation in Newport.................................58

Overview of Newport HOPE VI................................64 


\section{TABLE OF CONTENTS --Continued}

CHAPTER

PAGE

Corpus Christi Apartments................................................70

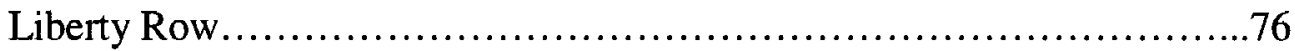

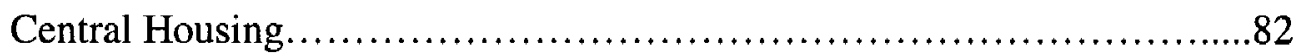

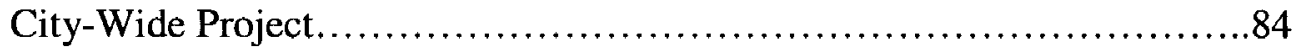

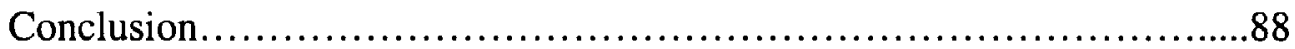

V. ANALYSIS OF COMMUNITY SUPPORTIVE SERVICES (CSS) PROGRAMS AND RESIDENTIAL SATISFACTION SURVEY ........................................91

Ongoing Outreach Efforts................................................97

Overall Project Effectiveness......................................98

Survey Instrument Measuring Residential Satisfaction...................101

Analysis to Survey Responses.....................................106

VI. ANALYSIS OF PROPERTY VALUE IN NEWPORT, KENTUCKY ........111

Property Value Data Analysis........................................111

Saratoga: HOPE VI Neighborhood...................................112

Liberty Housing: A HOPE VI Neighborhood.........................113

East Row: No HOPE VI, Historic District.............................115

Southwest Downtown: No HOPE VI and No Historic Preservation.......117

Comparing the Study Areas........................................119

Future Development Plans.........................................123 
TABLE OF CONTENTS-Continued

CHAPTER

PAGE

VII. A COMPARATIVE STUDY OF PROPERTY VALUES IN HOPE VI NEIGHBORHOODS IN NEWPORT AND LOUISVILLE'S PARK

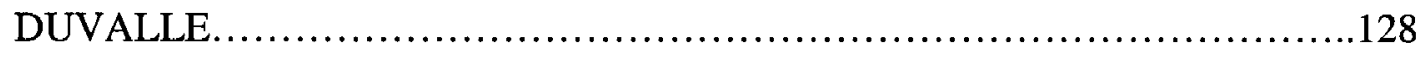

VIII. POLICY IMPLICATIONS AND CONCLUSIONS....................138

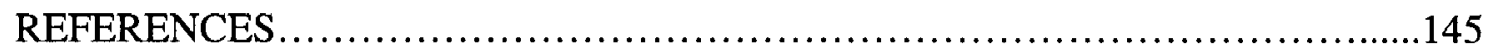

APPENDIX A: SURVEY OF HOPE VI RESIDENTIAL SATISFACTION..............156

APPENDIX B: RESULTS OF HOPE VI RESIDENTIAL SATISFACTION

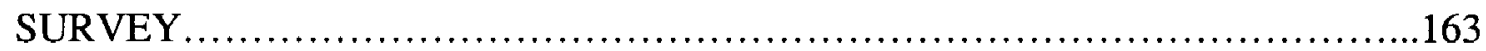

APPENDIX C: ANALYSIS OF CRIME IN NEWPORT ...........................171

APPENDIX D: BUSINESS STARTUPS IN NEWPORT .........................185

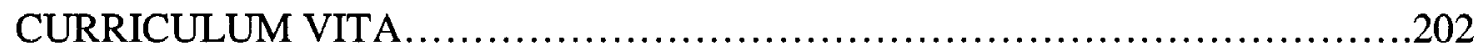




\section{LIST OF TABLES}

$\begin{array}{lll}\text { TABLE } & \text { PAGE }\end{array}$

4.1 Demographics of Newport and Campbell County $\ldots \ldots \ldots \ldots \ldots \ldots \ldots \ldots \ldots \ldots 45$

$5.1 \quad$ CSS Workplan Processes_June 30, 2007 ..............................99

5.2 Demographic Table of HOPE VI Residents.................................104

6.1 Ranges in Property Values between HOPE VI \& non-HOPE VI

Neighborhoods............................................................

6.2 Changes in Property Values in Cincinnati Metropolitan Area from

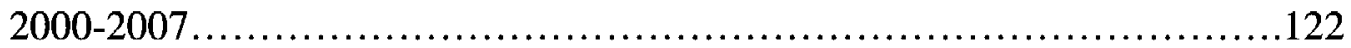

7.1 Property Value Appreciations by Census Tract in Louisville.................130

7.2 List of Independent Variables and their Predicted Directions.................132

$7.3 \quad$ Descriptive Statistics................................................. 133

7.4 Comparison of OLS Regression Results with Three Dependent Variables:

Median Housing Value, Dollar Change, and Percent Change...............135

C.1 Percent Change in Crime in Four Police Districts in Newport 2000-2007....181

C.2 Comparison of Crime in Covington, Newport, Cincinnati, Northern Kentucky and the United States................................................. 183

D.1 Main Street Façade Improvements in Downtown Newport..................199 


\section{LIST OF FIGURES}

FIGURE

PAGE

4.1 Map of the Cincinnati/Northern Kentucky Metropolitan Region...............45

4.2 Map of Newport's Neighborhoods....................................51

4.3 An advertisement about Newport as the Burlesque Capital of the Nation........52

4.4 Historic Home in East Row Historic District, Newport, KY ...................60

4.5 New headquarters of the Housing Authority of Newport.............................66

4.6 HOPE VI Developments as of August 14, 2008............................67

4.7 Housing Authority of Newport old public housing site......................68

4.8 Housing Authority of Newport old public housing site $\ldots \ldots \ldots \ldots \ldots \ldots \ldots \ldots . \ldots 6$

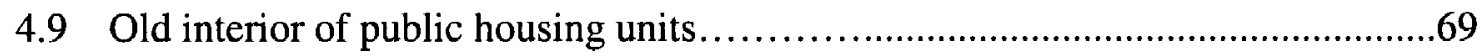

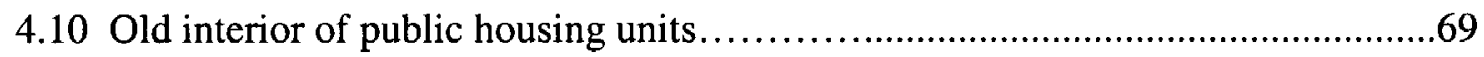

4.11 Corpus Christi Apartments............................................... 71

4.12 First floor plan, Corpus Christi apartments............................. 72

4.13 Corpus Christi second floor plan......................................... 73

4.14 Corpus Christi floor plan-third floor classroom unit...................... 74

4.15 Interior of Corpus Christi foyer.......................................... 75

4.16 Interior of apartment kitchen, Corpus Christi apartments...................75

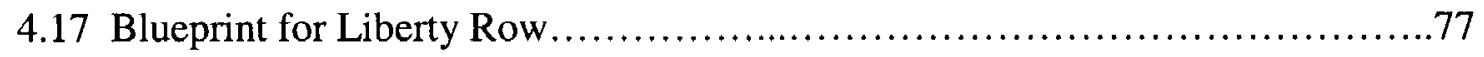

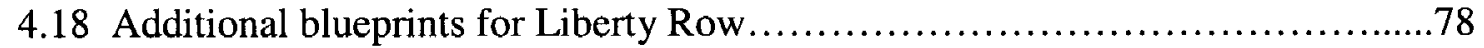

4.19 Photo of Liberty Housing, Phase II, under construction......................79 


\section{LIST OF FIGURES--Continued}

FIGURE

PAGE

4.20 Additional photo of Liberty Housing, Phase II, under construction..................79

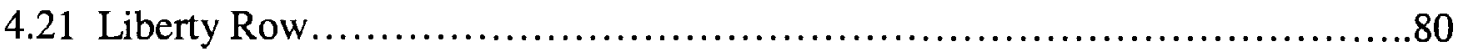

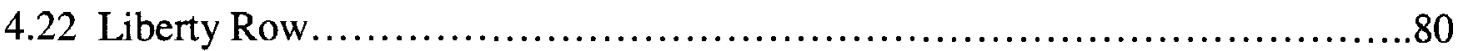

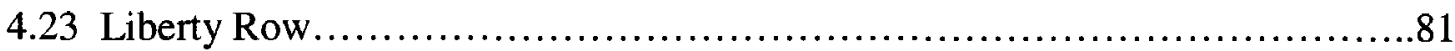

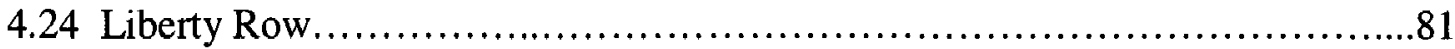

4.25 HOPE VI central housing rehabilitation, 316 Keturah St.......................82

4.26712 Isabella Street after rehabilitation....................................... 83

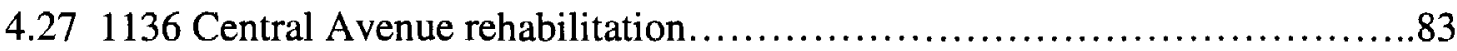

4.28 HOPE VI homes on Saratoga Street....................................... 86

4.29 HOPE VI homes on Saratoga Street...................................... 86

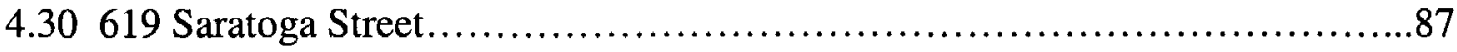

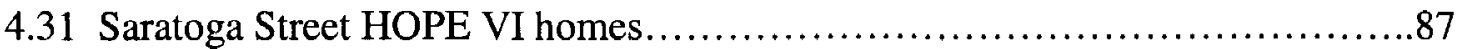

5.1 Newport CSS participants employed ...................................93

6.1. Changes in property values on Saratoga Street, $2000-2007 \ldots \ldots \ldots \ldots \ldots \ldots 113$

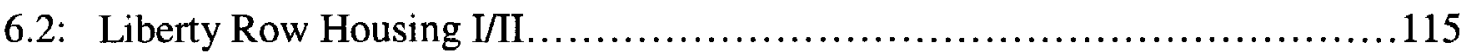

6.3 East Row Historic District............................................116

6.4 Change in property values in Southwest Downtown..........................118

6.12 Ovation development along Newport's Riverfront........................123

6.13. Ovation development along Newport's Riverfront..........................124

6.14 Ovation development along Newport's Riverfront.......................124 


\section{LIST OF FIGURES--Continued}

FIGURE

PAGE

C.1 Map of Newport police precincts.................................. 172

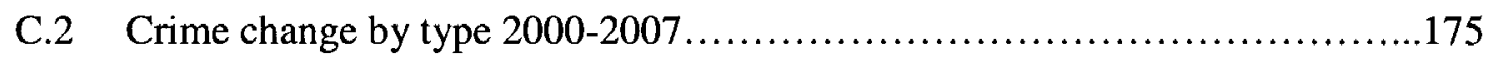

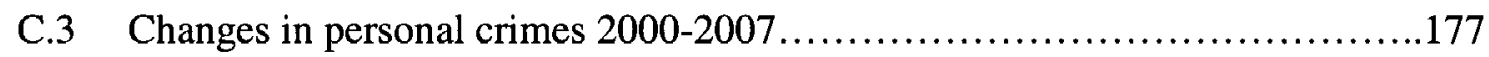

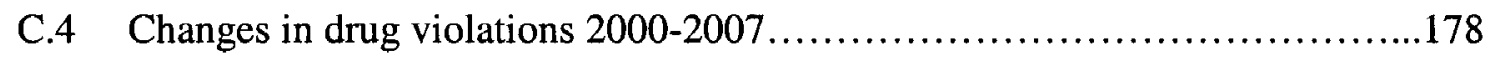

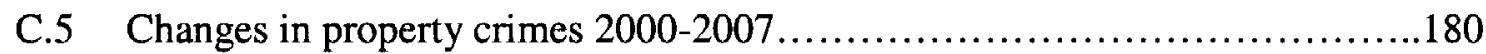

D.1. New Downtown businesses by category and percent growth by category......191

D.2 New business by category and percent growth by category........................191

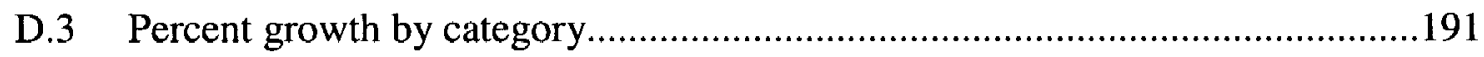

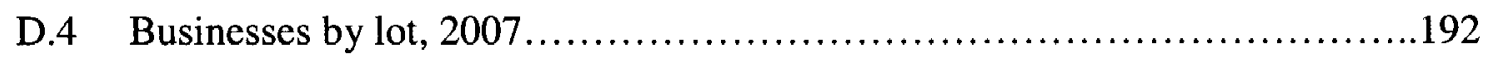

D.5. Business and streetscapes along Monmouth Street......................... 194

D.6. Marx-Cromer Building at $9^{\text {th }}$ and Monmouth Street..................... 195

D.7. Newport Central Business District by tenure, type, and lot, $2007 \ldots \ldots \ldots \ldots \ldots . . .198$ 


\section{CHAPTER 1}

\section{INTRODUCTION}

The purpose of this dissertation is to understand the impact of federal housing policy (HOPE VI) on the economic revitalization of cities. This dissertation aims to examine the impact of federal intervention programs like the Housing Opportunities for People Everywhere (HOPE VI) program on distressed neighborhoods. This dissertation's focus is on Newport, Kentucky, the smallest city in the United States to receive a HOPE VI grant. This city, located along the Ohio River across from downtown Cincinnati and situated within the greater Cincinnati and Northern Kentucky metropolitan region, has a population of 17,048 , according to the 2000 U.S. Census. This dissertation seeks to understand how Newport used local, state, and federal resources from the public and private sector in order to renew and revitalize its city and its downtown.

This dissertation will examine whether the HOPE VI program in Newport, Kentucky has played a role, if any, in improving the quality of life and satisfaction of the former public housing residents who participated in the HOPE VI program and Community and Supportive Services (CSS) case management program, and contributing to the increase in property values among HOPE VI and non-HOPE VI neighborhoods. This study uses a variety of methodologies that suggest a link between HOPE VI and the renewal of distressed neighborhoods that has sparked revitalization throughout the city. 
HOPE VI is an urban revitalization program created in 1992 by the U.S.

Department of Housing and Urban Development (HUD) that eliminates inadequate public housing that are products of the urban renewal style of the 1940s and 1950s, and replaces the old public housing with homes in mixed-income communities through providing self-sufficiency services to the residents of the community through local government and non-profit agencies (Schwartz, 2006; Popkin, Levy, Harris, Comey, Cunningham, \& Buron, 2004; U.S. Department of Housing and Urban Development [HUD], 1999; HUD, 2000).

Jack Kemp, the Secretary for Housing and Urban Development during the administration of the senior George Bush, passionately pushed for a federal program aimed toward homeownership for public housing residents by using a combination of public and private dollars and the market to encourage homeownership, as well as the creation of tenant management organizations in public housing developments, where tenants can have control over their own households (Marcuse \& Keating, 2006, 152). Homeownership fits into the conservative, Republican Party philosophy of promoting personal responsibility and taking government out of the housing business (Marcuse \& Keating, 2006, 152-153).

Attempts by the recent George W. Bush administration to reduce and eliminate funding for HOPE VI have made this dissertation timely and important in documenting the impact of a federal program like HOPE VI. The best way to ensure livable and sustainable communities and revitalize distressed communities is through homeownership, partly because homeownership symbolizes a family's social status, and is also seen as an alternative to renting or living in public housing (Hayden, 2002). Good 
housing is seen as the key to sustainable neighborhoods. Homeownership is more advantageous than renting because homeowners can build equity and enjoy certain tax exemptions from paying capital gains taxes (Bogart, 1998, 286).

Purchasing and owning a home, as evidenced by the work of the University of Louisville's Housing and Neighborhood Development Strategies (HANDS) and the Sustainable Urban Neighborhoods (SUN) programs in Louisville's Russell neighborhood, not only improves one's credit and helps build equity, but owning a home can boost a person's confidence and create a sense of self and self-identity (Gilderbloom \& Mullins, 2005; Marcus, 2006). The symbolic role of the home is an expression of the social identity that we communicate and display to our neighbors, community, and the world at-large (Marcus, 2006, 8). Having a place to call "home" is crucial in the personal development of the individual. Owning a home is a rite of passage symbolizing that a person has achieved a certain economic status, which increases an individual's satisfaction (Rohe, Van Zandt, \& McCarthy, 2001). More importantly, owning a home is a crucial factor in increasing the economic and financial health, livability, and sustainability of a neighborhood, community, and city.

HOPE VI was developed out of the Department of Housing and Urban Development Reform Act and through the establishment of the National Commission on Severely Distressed Public Housing in 1989, which estimated that six percent of the total housing stock, approximately 86,000 total units, in the United States were severely distressed and uninhabitable (HUD, 1992; HUD, 2000; Popkin \& Cunningham, 2000; Popkin, Katz, Cunningham, Brown, Gustafson \& Turner, 2004; Schwartz, 2006, 116; Brazley \& Gilderbloom, 2007; Gilderbloom, 2008). 
The HOPE VI program has five important objectives: change the physical shape of public housing, reduce the concentration of poverty, provide support services, establish and maintain high standards of community and personal responsibility, and develop partnerships between public and private agencies and organizations (HUD, 1992; HUD, 1999; HUD, 2000; Schwartz, 2006; Popkin, et al., 2000; 2004; Popkin, 2002;

Subcommittee on Housing and Transportation, Committee on Banking, Housing, and Urban Affairs, U.S. Senate [GAO], 2002; Gilderbloom \& Hanka, 2006; Brazley \& Gilderbloom, 2007; Gilderbloom, 2008).

From the inception of HOPE VI in 1992, which provided an initial appropriation of $\$ 300$ million planning and implementation grants to public housing authorities, through 2004,558 grants have been administered and 224 public housing projects have been demolished and redeveloped, resulting in over $\$ 6$ billion in total investment (Turner, Woolley, Kingsley, Popkin, Levy, \& Cove, 2007). HOPE VI projects have occurred in larger metropolitan areas like New York, Chicago, and Los Angeles, but also in medium and smaller cities like Newport. HOPE VI is more than the physical demolition and redevelopment of distressed properties; it also provides social services to residents through Community and Supportive Services (CSS), the case management program of HOPE VI (HUD, 1992; HUD, 1999; HUD, 2000; Popkin, et al., 2000; Varady \& Preiser, 1998; Popkin, 2002; Turner et al., 2007).

This initiative supports the development of local strategies and programs to help public housing residents obtain employment, and provide training assistance through education, employment counseling, job training, household skills training, childcare services, transportation, substance abuse treatment and counseling. Also included is 
homeownership counseling that will lead towards self-sufficiency and economic independence (HUD, 1999; Brazley \& Gilderbloom, 2007; Gilderbloom, 2008;

Gilderbloom \& Hanka, 2006; Popkin, et al., 2004).

Besides changing the physical shape of the housing and providing support services, HOPE VI emphasizes personal and community responsibility through "community sweat equity" by instilling in residents that economic independence and selfsufficiency comes with an obligation and responsibility to give back to one's community (Popkin, et al., 2004; HUD, 2000; Thompson, 2006). The HOPE VI program provides underserved communities with access to the social and economic capital necessary to create and revitalize neighborhood and community institutions, such as strong schools, businesses, and community organizations, which are the necessary building blocks for sustainable, stable, attractive, and livable communities (Gilderbloom, 2008, 139).

The HOPE VI project in Newport attempts to deconcentrate poverty through the development of scattered-site housing, which is defined by Varady and Preiser (1998, $190)$ as the number of units on a site, anywhere between two and 300 , the kinds of structures, which could be single-family homes, duplexes, and townhouses, as well as the extent of deconcentration away from "concentrations of low-income, minority populations." The Housing Authority of Newport (HAN) has purchased sites in neighborhoods throughout the city of Newport and has constructed single family homes, duplexes, and apartment units scattered throughout the city to rent to former residents of the public housing area or sell to potential homebuyers.

For much of the early to mid- $20^{\text {th }}$ century, Newport was a center of prostitution, gambling, and vice, and a city controlled by corrupt elected officials and organized crime. 
The same mafia that controlled the casinos, drugs, and prostitution in Las Vegas and Havana did the same in Newport, turning it into the "Vice Capital of the South," or also known as the "Gomorrah of America" (Goldfarb, 1995, 84). Monmouth Street, the major thoroughfare in Newport's Central Business District, was littered with nightclubs and 23 adult-entertainment establishments and 80 bars and casinos. Like world famous cities such as Las Vegas and Havana, Newport was also home to the famous Tropicana Club.

In the 1960 s, gambling and prostitution dominated the town and had become the largest center of national betting syndicates, with estimates that $\$ 30$ million was gambled in Newport every year (Goldfarb, 1995, 83-84). Using the unfair arrest of Newport reformer and Campbell County Sherriff Candidate George Ratterman in 1961, Attorney General Robert F. Kennedy led a public crusade to remove the gamblers and vice from the city. This crusade brought national attention to Newport and stigmatized the city for years. However, in the years after the crackdown, vice and prostitution still lingered, the city deteriorated, and little business and economic activity occurred in the city.

This dissertation traces how Newport transitioned from "vice" to "nice," from casinos to aquariums, from strip clubs to sports bars and restaurants, from "hips" to "hip" and from poverty and hopelessness to self-sufficiency. Despite its checkered past, Newport has the potential to become a place of economic growth and renewal through creating opportunities for homeownership and economic investment to improve communities, and make the transition from "vice" to "nice." We discuss this transformation in the upcoming chapters. The next chapter will provide a review of the literature on housing policy from the New Deal era to today, followed by a literature 
overview of the impact of modern era federal housing policy through homeownership, which became known as HOPE VI. 


\section{CHAPTER II}

\section{REVIEW OF THE LITERATURE}

The intervention of the federal government in public housing began through the federal works program of President Franklin D. Roosevelt's New Deal in the 1930s through the passage of the National Housing Act of 1934. This landmark housing legislation established the Federal Housing Administration (FHA) to improve housing conditions and standards, which later led to the formation of the Department of Housing and Urban Development (HUD). The practice of redlining, which targets specific areas and neighborhoods based on racial and ethnic groupings and was prevalent through the 1960s, was an indirect consequence of the National Housing Act of 1934. Redlining established four categories of neighborhood quality. The lowest category, category one, was coded red and consisted of all-white, all-Protestant American business and professional men. Racially and ethnically-mixed and Jewish neighborhoods were placed in categories two or three, depending on economic status, while black segregated neighborhoods were placed in category four (Massey \& Denton, 1993, 51-52; Rohe \& Watson, 2007, 36-37; Hayden, 2004, 124-125).

Since private banks relied heavily on the Home Owners Loan Corporation (HOLC) to make loan decisions, this further institutionalized the process of redlining and discrimination in housing (Massey \& Denton, 1993, 52). The discriminatory practices of 
the 1934 Housing Act led to the Federal Housing Act of 1937, which was a permanent government program that provided loans and subsidies to municipal housing authorities to eliminate slums and provide low-income housing. The federal government provided the loans while local governments exempted the housing costs from personal and property taxes (Schwartz, 2006; Marcuse, 2001). This act was designed to develop housing for poor residents of urban areas. This act also required cities to target specific areas and neighborhoods for different racial groups who were not eligible to receive loans. Ethnic minorities could only receive loans in certain areas, which resulted in a large increase in residential racial segregation in the United States.

The Housing Act of 1949, which began the era of urban renewal, was a compromise between the liberal and conservative housing policy approaches and served as the federal government's framework for urban redevelopment over the next two decades (Kleinberg, 1995). This act resulted in a city housing authority selecting a renewal site, purchasing the given site at fair market value, clearing the site, and selling the land to a private developer at a lower price than the private developers would have paid for on the private market. The federal government subsidized two-thirds of the "write down" costs associated with purchasing and clearing the property, while the local authority pays one-third of the cost (Kleinberg, 1995, 142-143: Schwartz, 2006; Marcuse, 2001).

Questions of housing affordability are important in liberal housing policy because there is no attempt to influence the cost-structure of our market-dominated housing system (Hartman, 1983, 4). Housing affordability is becoming more of an issue because 
many homeowners are increasingly spending a higher percentage of their incomes on housing (Marcuse, 2001; Gilderbloom, 2008).

Conservative housing policy, on the other hand, favors the free market over government intervention. Conservatives favor local versus federal decision-making, no zoning regulations for development, and an ideology that stresses private property rights, efficiency, and individual effort (Marcuse, 2001, 720-723; Gilderbloom \& Appelbaum, 1988). According to conservatives, solving the housing crisis comes from creating more housing through the market. If enough housing is created and brought to the market, vacancy rates will increase, the price of rent will drop, and there will be ample affordable housing. The greater the housing supply, the lower the rents, and the larger the market of available housing, the more competitive the urban area will be in attracting new growth (Gilderbloom, Ye, Hanka, \& Usher, 2009). Critics of free market, conservative housing policy suggest that the free market does not help provide affordable housing to the poor. Harloe (1985: 380) argues that "the problem is that the free market has, historically, been unable to provide housing at socially acceptable standards at a cost which is affordable by low-income households."

Urban renewal and slum clearing programs of the 1950s helped label public housing as lower-class and substandard. The architectural nature of early and relatively recent public housing developments, both low-rise "barracks" style housing and high rise buildings, were highly dense structures that isolated residents from the surrounding streetscape with no access to transportation and social services, and lacked any outdoor exterior amenities and features (Schwartz, 2006, 108-111). The creation of LeCorbusier style high-rise concrete apartment units instead of single-unit housing (i.e., Robert Taylor 
Homes and Cabrini Green in Chicago), and the lack of "defensible space" (Newman, 1973) caused public housing to become a target of crime, vandalism, and drugs, which helped contribute to creating and perpetuating the culture of poverty (Wilson, 1987).

The design of these simple no-frill housing units stigmatized residents as poor and not deserving of any better designed housing. Moreover, no frills housing was rooted in socialist ideology that no person should have a better designed house than the other. The one notable break from cheap and "simple is better" design housing comes from the Amsterdam School, an extension of modern Expressionism and art-deco that separates form from function and is characterized by organic features, and non-functional, decorative and aesthetic elements (Musterd \& Salet, 2003).

Traditional public housing after urban renewal alienated residents from their homes, which gave them little control of its uses, such as interior design, living space, and entertaining guests (Gilderbloom, Brazley, Alam, Ashan, \& Ramsey, 2002, 22). More importantly, the plain ordinary, prison-like quality of public housing creates a sense of stigmatization for the poor and marginalized who are confined to live in these dwellings. This stigmatization is prevalent in the public housing in numerous cities such as St. Louis, New York, London, Paris, Chicago, Havana, Louisville, and Newport. Wilson $(1987,137)$ argues that the stigmatization and the traits of the culture of poverty "assume 'a life of their own' and continue to influence behavior even if opportunities for social mobility improve."

A major contributor to the destruction of urban communities was the result of the Federal Highway Act of 1956. This legislation began the proliferation of moving people away from downtown and into the suburbs and was seen as conservative response to 
federal policies on the future development of central cities with respect to the Housing Act of 1949 (Walker, Kulash, \& McHugh, 2007, F2/2; Kleinberg, 1995, 129). During this time, a person's life, including one's home, office, school, and recreation activities, was located in the suburbs. The growth of the suburbs helped "smooth the route home from work" where all the jobs and entertainment in the downtown moved out to the suburbs (Eversley, 2006).

This movement to the suburbs is the context in which downtown one-way streets developed, where LeCorbusier envisioned "great arterial roads for express one-way traffic" (Jacobs, 1961: 31). A grid of one-way streets has facilitated "the speedy entrance and exodus of commuters" back to the suburbs, an ideal that stems from the $1950 \mathrm{~s}$ (Walker et al., 2007). Now, city planners and engineers are reevaluating the practicality of one-way streets in urban life. Several neighborhoods in Louisville are redoing their one-way streets to two-way streets (Hanka and Gilderbloom, 2008).

The interstate federal highway system and movement to the suburbs destroyed minority and working-class neighborhoods and communities to make way for the multilane highway systems (Kleinberg, 1995, 130). The placement of the highways further segregated blacks and poor whites from access to jobs and services located in the suburbs (Kleinberg, 1995, 130). These populations do not have the money or resources to move out to the suburbs. They were trapped in substandard housing and lacked the transportation or the wherewithal to move to the suburbs.

The late 1960s and early 1970s were seen as a favorable climate for liberal housing policy (Marcuse, 2001). In 1961 Jane Jacobs provided a strong critique of urban renewal in The Death and Life of Great American Cities by arguing that extensive slum 
clearance and renewal only added to the existing problems. She adds: "At best it merely shifts slums from here to there, adding its own tincture of extra hardship and disruption. At worst it destroys neighborhoods where constructive and improving communities exist and where the situation calls for encouragement rather than destruction" $(1961,353)$. Jacobs identifies the problems of urban renewal as paternalistic and only being solved superficially. She describes the notion of "perpetual slums" that show no sign of improving and often regress after a little improvement (Jacobs, 1961, 346). To overcome this slum mentality, Jacobs argues that

we must regard slum dwellers as people capable of understanding and acting upon their own self-interests, which they certainly are. We need to discern, respect and build upon the forces for regeneration that exist in slums themselves, and that demonstrably work in real cities. This is far from trying to patronize people into a better life, and it is far from what is done today. $(1961,354)$

The Civil Rights Act of 1964 was important for housing policy by removing racial deed restrictions and restrictive covenants, which were legally enforceable provisions of deeds that prohibited owners from selling or leasing their properties to specific racial groups (Plotkin, 2001). The Supreme Court successfully overturned the constitutionality of race restrictive covenants in the 1948 ruling of Shelley v. Kraemer (Schwartz, 2006, 239).

The Civil Rights Act of 1964, however, did not end the use of restrictive covenants nor did it end the practice redlining. The Fair Housing Act of 1968 prohibited discrimination in housing and the real estate market by making it unlawful to refuse to rent or sell a home on the basis of race and barred discrimination in real estate advertising (Schwartz, 2006, 239-240; Massey and Denton, 1993, 195). The Fair Housing Act of 1968 had difficulty with the limited resources and provisions to enforce the law, relying 
on individuals to identify housing discrimination themselves (Briggs, 2005; Massey \& Denton, 1993; Schwartz, 2006).

Much of the growth of public housing, from urban renewal through the 1980s through direct government opposition to integration and deliberate de jure segregation, occurred as a result of opposition by neighborhood, community, and NIMBY (Not in My Back Yard) groups to keep public housing out of their neighborhoods (Wilson, 1987, 38; Calhoun, 1994). This opposition was mostly from the government and not from the private sector. Redlining, exclusionary zoning, and the creation of massive public housing projects in low-income areas, helped to intensify racial segregation in public housing. This racial segregation in public housing has contributed to high concentrated poverty, violent crime, lack of employment, racial and institutional discrimination, and social isolation, which are the "social and institutional mechanisms that enhance patterns of social dislocation" caused by racial subjugation, class transformation, and decline of the social organization of the inner city (Wilson, 1987, 137-138).

Massey and Denton $(1993,87)$ argue that de facto segregation and discrimination on the basis of race continues to exist in larger metropolitan areas, which affects the ability for blacks and minorities to be treated fairly on the open housing market and has perpetuated the growth of the urban underclass and further intensifies discrimination and racism. The literature also addresses the importance of HOPE VI in eliminating the culture of poverty and racial segregation that has plagued the older model of public housing projects, where many poor minority populations were concentrated in these developments (Wilson, 1987; Massey \& Denton, 1993; Briggs, 2005; Lees, Slater, \& Wyly, 2008). 
The policies implemented under urban renewal shifted towards developing new communities in the late 1960s and 1970s. The Housing Act of 1968 focused on specific targets aimed at the expansion of building low-income housing, low-interest loans and rental subsidies for low and moderate-income households (Marcuse, 2001, 727-728; Schwartz, 2006, 113). The Experimental Housing Allowance program launched in 1973 provided allowances for families to choose their own housing. The Housing Act of 1974 created Community Development Block Grants (CDBG), which provided allowances to low-income households in the form of rental subsidies for residents to pay for the cost of a private rental unit or an apartment. These rental subsidies were followed by the introduction of vouchers in the 1980s by HUD that allowed families to choose any kind of housing as long as it followed the program requirements of Section 8 , and if the landlord participated in the program (Varady \& Walker, 2003, 18; Varady, Walker, \& Wang, 2001).

The remedy to end redlining practices and disinvestment in low and moderate income and minority neighborhoods occurred through the passage of the Community Reinvestment Act of 1977, which required giving credit to banks and financial institutions in order to finance low-income housing in specific geographic places, including high poverty, underserved neighborhoods (Briggs, 2005, 198-204). This legislation outlawed the practice of redlining, although it did not stop it altogether. This legislation acted as an incentive to encourage home mortgages loans, small business and banking services in these low-income and minority communities (Briggs, 2005, 204; Rohe \& Watson, 2007, 272). 
In addition to liberal and governmental interventionist policies like rental subsidies and Section 8 vouchers, the literature criticizes the liberal policy of rent control. Rent control refers to laws passed by cities that set price controls (or price ceilings) on rents, which protects tenants from extreme rent increases and unjust evictions, and enables tenants to organize unions and organizations to protect themselves against landlords (Gilderbloom, 1988, 128). Much of the literature opposes rent control because it interferes with the landlord's ability to respond to the market, which reduces profitability, discourages new construction, resulting in a deteriorating housing stock (Gilderbloom, 2008, 69; Gilderbloom \& Appelbaum, 1988). Conservatives such as Milton Friedman argued that high rent ceilings caused "haphazard and arbitrary allocation of space, inefficient use of space, and retardation of new construction" (Friedman \& Sigler, 1946). Gilderbloom and Ye (2007) found rent control to be more a symbolic gesture than distributional.

\section{HOPE VI Impacts}

Much of the literature suggests that the impact of HOPE VI across the country has been mixed. Residents who relocate into HOPE VI neighborhoods are living in better and safer communities (Thompson, 2006). Before HOPE VI, the Supreme Court decision in 1976 found the Chicago Housing Authority (CHA) guilty of racial discrimination forcing the CHA to create the Gautreaux project named after Chicago housing activist Dorothy Gautreaux. This program called for the creation of new public housing in scattered sites through deconcentrating poverty and dispersing the poor into the private rental market through initially providing 7,100 Section 8 certificates to current and former CHA 
residents in neighborhoods that were less than 30 percent black (Brazley, 2002; Popkin, Buron, Levy, \& Cunningham, 2000, 912).

Over the next twenty years, the Gautreaux program positioned the city of Chicago and the Chicago Housing Authority (CHA) to receive four HOPE VI grants for developments in Robert Taylor Homes, Rockwell Gardens, Stateway Gardens, and Henry Horner Homes (Chicago Housing Authority, 2008). In 1999 the CHA announced its "Plan for Transformation," which calls for the demolition of 51 high-rise public housing and several hundred middle and low rise units, including the high crime and high poverty Robert Taylor Homes and Cabrini Green, eliminating 14,000 units and relocating 6,000 families, and replacing them with 6,100 mixed income units and 9,500 senior citizens rehabilitated units at a cost of $\$ 1.5$ billion (Popkin, et al., 2000, 918-919; Thompson, 2006).

Popkin et al. (2000), Rosenbaum (1991), Rosenbaum, Popkin, Kaufman, and Rusin (1991), Kaufman and Rosenbaum (1992), and Rubinowitz and Rosenbaum (2000) studied the effects of the Gautreaux program by comparing residents who moved to suburban neighborhoods and residents who stayed within the city of Chicago and observed enormous benefits, such as increased employment and educational opportunities, and greater social and economic integration by the residents into their new neighborhoods (Rosenbaum et al., 1991).

In 2000, the U.S. Department of Housing and Urban Development published its first evaluation report of HOPE VI, which examines the accomplishments of HOPE VI development in eight U.S. cities, including Atlanta, Baltimore, Columbus, El Paso, Milwaukee, Oakland, San Francisco, and Seattle (HUD, 2000). According to this report, 
HOPE VI has fulfilled its main goals and objectives of community building, helping residents achieve self-sufficiency through improving education, job training, and homeownership through the case management programs, Community and Supportive Services (CSS) program, increasing employment opportunities and income, dramatically reducing crime and violence, improving the physical shape of the housing, community policing and improving crime prevention programs.

Also HOPE VI has eliminated the isolating of public housing through scattered site development, and also leveraged more public investments in community development and neighborhood revitalization (HUD, 2000; Popkin et al., 2004; GAO Report, 2002). Wyly and Hamel (1999), Byrne (2003), and Lees, Slater and Wyly (2008) have shown that redevelopment of public housing in HOPE VI programs has opened up areas for investment and has integrated residential neighborhoods by income. This is a "startling contrast to the patterns that have typified metropolitan development for 100 years" (Byrne, 2003, 429).

However, critics have complained that HOPE VI has removed and demolished more affordable housing units than what has been put back in its place, resulting in hundreds and thousands of displaced public housing residents. The literature cites that more units have been replaced than the number of units that have been demolished under HOPE VI (between 88,500 and 94,500), and only half (approximately 48,000) of these units will receive the subsidies necessary to support low-income households (Popkin \& Cunningham, 2005; Schwartz, 2006, 118-119; Turner et al., 2007, 4). However, Gilderbloom $(2008,116)$ states that out of the 115,000 units that will be demolished 
under HOPE VI, only 60,000 new or rehabilitated units will replace the old units, resulting in a shortage of 55,000 public housing units.

The HOPE VI program repealed the "one-for one" public housing replacement requirement for public housing demolitions, because this replacement was viewed as an obstacle towards demolishing these communities. Section 24 of the Quality Housing and Work Responsibility Act of 1998 (QHWRA) excused the HOPE VI program from the requirements of replacing the units one by one, which has resulted in the replacement of only about one affordable unit for every five destroyed (Williams, 2003). According to Philip Tegeler, the repeal of this requirement also has eliminated many scattered site developments outside of minority areas, resulting in the rebuilding of highly concentrated segregated low income neighborhoods that lacked adequate replacement housing to accommodate tenants who were displaced voluntarily by the HOPE VI redevelopment (Briggs, 2005, 206-207; Popkin, et al., 2004, 29).

The General Accounting Office (GAO) estimated in 1999 that 61 percent of the original public housing residents would return to the new HOPE VI developments (Schwartz, 2006, 121). However, Popkin, et al. (2004, 28-30) found that only 19 percent of the public housing residents will return to live in a HOPE VI development. Out of the 1,273 households who lived in the Cotter and Lang public housing projects in Park DuValle in Louisville, only 150 households planned to live in the new HOPE VI development (Brazley, 2002; Brazley \& Gilderbloom, 2007, 439; Gilderbloom, 2008, 124).

Critics of Moving To Opportunity (MTO) housing programs, such as Section 8 and HOPE VI, argue that the crime would increase in the areas where residents moved 
and would bring the crime with them (Rosin, 2007). Due to lack of funding, HOPE VI had reduced its ability and capacity to serve the "hard to house" residents, which are residents that are at-risk of losing their homes, the elderly and the disabled, one-strike families with ex-offenders and convicted criminals, grandparents who are the primary caregivers for their grandchildren, and large families with a high number of occupants in the housing dwelling (Cunningham, Popkin, \& Burt, 2005, 2-6; Popkin, Theodos, Roman, Guernsey, \& Getsigner, 2008, 9).

Studies by Popkin (2000) and Popkin and Cunningham $(1999,2000)$ reveal the problems that Section 8 participants have faced and discovered that many of the residents were not prepared and ill-equipped and faced extraordinary challenges in making a successful transition to the private housing market. This difficulty in transitioning was due to many problems, such as violent conditions in public housing, residents with criminal records, residents lacking the skills and knowledge to make the transition, as well as personal problems (Popkin et al., 2000, 925-927). Studies by Cunningham (2001) have revealed that the presence of HOPE VI in gentrifying neighborhoods does not aid but reduces affordable housing in distressed neighborhoods, especially in neighborhoods with rents and home prices spiraling upward (Lees, Slater, \& Wyly, 2008, 205).

\section{Scattered-site Public Housing}

Robert Taylor Homes and Cabrini Green in Chicago and the Pruitt Igoe Housing Development in St. Louis are examples of the failure of public high rise housing projects. Pruitt-Igoe housed 10,000 people in 33 eleven story buildings covering 57 acres, and closed in 1976 because of high levels of despair, vandalism, and crime (Von Hoffman, n.d). Robert Taylor Homes housed 20,000 residents in twenty-eight sixteen story 
buildings covering 92 acres. Out of a population of three million people, Robert Taylor Homes represented 11 percent of Chicago's murders, 9 percent of the rapes, and 10 percent of the aggravated assaults in 1980 (Wilson, 1987, 25). The highly-dense, highrise physical shape of the public housing and its location in relation to basic services, schools, and employment opportunities produced an isolating and segregating effect from the rest of the community, including residents who want to keep poor public housing residents out of their neighborhoods and communities.

Place and geography have enormous impacts on where people live and whether people become homeowners (Dreier, Mollenkopf, \& Swanstrom, 2001; Galster \& Killen, 1995; Galster \& Mikelsons, 1995; Reid, 2007). According to Dreier et al. (2001, 21), place matters, because where you live has a powerful effect on the choices and opportunities and the quality of life of the citizenry of the area. In order to deconcentrate poverty, people must move from areas of high concentrations of poverty into more affluent areas, and that moving the poor to more affluent areas would reduce the gap between rich and poor and increase the likelihood of economic integration (Dreier et al., 2001, 224-225). Through government intervention, creating new localities that would deconcentrate poverty, promote economic integration, and empower the underclass will improve the lives of the poor and marginalized.

Scattered site housing, as seen in HOPE VI and other public housing initiatives, has come from the geography of opportunity hypothesis, which argues that where an individual lives has an affect on his or her opportunities and life outcomes (Rosenbaum, 1995, 231). Briggs (2005) describes an "uneven geography of opportunity" where the location of housing restricts access to economic and social opportunities, and increases a 
resident's exposure to air pollution and highway congestion. Even though the uneven geography of opportunity hurts suburban residents as much as inner city residents, especially through the increase of urban sprawl, suburban residents still have greater economic advantages (Briggs, 2005, x-xii). The Gautreaux study in Chicago looked at how escaping concentrated poverty and the uneven geography of opportunity and integrating low income individuals into middle class areas will lead to improvements in employment, education and social integration (Rosenbaum, 1995, 265-266; Galster \& Killen, 1995; Wilson, 1987; Brazley, 2002; Briggs, 2005; Gilderbloom, 2008).

Imbroscio (2008) challenges advocates of the Moving to Opportunity (MTO) and assisted mobility programs like Gautreaux, otherwise known as the dispersal consensus. He argues that the decisions of low income residents to move to middle and upper class areas do not take into account the context of their decisions and their choice to move. Their decisions become nothing more than "a desperate response to a desperate set of conditions with little to do with any real notion of freedom of choice" (Imbroscio, 2004; Imbroscio, 2008, 115).

Galster and Mikelsons (1995) Galster (1996), and Reid (2007) extrapolate the geography of opportunity hypothesis and the linkages between geography and opportunity into the metropolitan opportunity structure, which is the set of institutions, markets, social and administrative systems and networks, and the individual's perception of the structures available to them, influenced by geography, that impacts an individual's socioeconomic mobility. Where a person buys a home will affect their opportunities, because it may provide greater home equity through increased property values, as well as 
increased opportunities in education and employment, reduced exposure to crime, and an increase in self-esteem, satisfaction and well-being (Rohe \& Watson, 2007, 234-235).

Place and geography have enormous impacts on where people live and whether people become homeowners (Dreier et al., 2001; Galster \& Killen, 1995; Galster \& Mikelsons, 1995; Reid, 2007). Removing public housing residents from their place and location through scattered-site housing not only deconcentrates poverty, but it removes the sense of identity the residents have toward the public housing in which they live and the opportunities and life outcomes they receive from their place and geographic location. Residents have used identity as a way to affirm their attachment to a particular place, such as the public housing. Thus, the demolition of the public housing through HOPE VI can be seen as an attack on their identity and the potential displacement from their public housing dwellings would ultimately disrupt friendship ties and social networks (Gotham, 2003, 730).

Scattered-site housing has produced high levels of neighborhood satisfaction among former public housing residents, has reduced fears of crime, provided better employment opportunities for adults, increased educational opportunities for children, increased neighborhood social interaction, and reduced the cost burden of housing (Burby \& Rohe, 1989; Rosenbaum \& Popkin, 1990; Rosenbaum, 1993, 1995; Galster \& Killen, 1995; Goetz, 2000; Varady \& Preiser, 1998; Brazley, 2002; Popkin, et al., 2000b; Brazley, 2002; Gilderbloom, 2008).

Varady and Walker (2003) argue that the use of housing vouchers (tenant-based subsidies) has helped deconcentrate poverty in some areas by improving the quality of life of former public housing residents by moving them into neighborhoods that have 
higher mobility, better schools, and safer neighborhoods. However, in large urban areas like Chicago, recipients who used vouchers lived in neighborhoods with less drugs and crime and lower poverty rates than their old public housing (Varady \& Walker, 2003).

Also, residents relocating to deconcentrated minority areas have experienced difficulty in making the transition to their new housing, either by adjusting to a new housing environment, overcoming fears of discrimination in predominantly white areas, the lack of affordable housing, the lack of public transportation in the suburban areas, and landlords unwilling to accept vouchers (Varady \& Walker, 2003; Popkin, 1999; 2000). Also, the most vulnerable public housing residents that experience the greatest social problems, such as substance abuse and domestic violence, may not qualify for assistance from HOPE VI and Section 8 vouchers, or receive any assistance on the private market (Popkin et al., 2000, 933-934).

Although studies have shown that HOPE VI has significantly eliminated concentration of poverty, little has been done to reduce the large racial concentrations in many of these new developments (Brazley, 2002; Kingsley, Johnson, \& Petit, 2003;

Gilderbloom, 2008). Many of the HOPE VI projects are built on the old public housing sites, which reinforces the residential segregation in these public housing developments by failing to integrate in the larger community, as is the case with the HOPE program in Park DuValle in Louisville (Brazley, 2002; Gilderbloom, 2008, 119). Today, only two white residents live in Park DuValle among the 1,273 households. A more promising approach is with the Liberty Green HOPE VI project, also in Louisville, which is more integrated into the downtown area and surrounding neighborhoods. In the relocation of residents in Chicago's public housing projects, many of these residents relocated to 
neighborhoods that were 90 percent African-American (Popkin et al., 2002; Popkin et al., 2004, 29).

The literature also focuses on the costs associated with HOPE VI developments. The average median cost per development is $\$ 160,400$, which encompasses the total cost of the home, including construction and labor costs, of which 37 percent of the cost is covered by HUD funds and 25 percent of the costs comes from private sources (Turner et al., 2007, 16). The average costs of a mixed construction and rehabilitation development is $\$ 165,800$, and the median rehabilitation development cost is $\$ 131,800$, while the median costs for medium size metropolitan areas is $\$ 172,800$ (Turner et al., 2007, 16-18). The total cost of each development also includes the costs associated with the Community and Supportive Services (CSS), the case management program of HOPE VI. In the HOPE VI development in Louisville's Park DuValle neighborhood, the average cost per housing unit is $\$ 169,000$, but will drop to $\$ 139,000$ when all 1,273 units will be built (Brazley \& Gilderbloom, 2007, 440; Gilderbloom, 2008). Compared to Park DuValle, the development in Louisville's Russell neighborhood, through the Louisville Central Development Corporation, built units for two or three times less than the HOPE VI units, including three bedroom, one bathroom units for $\$ 49,500$ (Gilderbloom \& Mullins, 2005; Brazley \& Gilderbloom, 2007, 439-440; Gilderbloom, 2008, 126). Also, HOPE VI funding has an economic multiplier and leveraging effect. According to a 2001 General Accountability Office (GAO) Report, for every $\$ 1$ of federal funds spent on HOPE VI, \$1.85 more comes from local housing authorities (GAO Report, 2002; Popkin et al., 2004, 24). With the approximately $\$ 6$ billion spent on HOPE VI since 1993 , approximately $\$ 11.1$ billion in funds ( $\$ 9$ billion of that non-HUD funds) 
has been leveraged primarily through other federal sources, as opposed to other private sources (GAO Report, 2002; Popkin et al., 2004, 24).

\section{Residential Satisfaction}

The literature shows several studies on whether public housing residents benefit from scattered-site housing like HOPE VI and experience greater residential satisfaction and improved the quality of life (Burby \& Rohe, 1989; Rosenbaum \& Popkin, 1990;

Rohe \& Stegman, 1994; Popkin et al., 2000; Rosenbaum \& Harris, 2001; Varady \& Preiser, 1998; Varady, Walker, \& Wang, 2001; Popkin, 2002; Popkin, et al., 2004).

Susan Popkin et al. (2000) studies the impact of the Gautreaux housing project in Chicago and Michael Brazley's (2002) study of the HOPE VI project in Park DuValle in Louisville's west end measures the neighborhood and residential satisfaction of the residents, and shows that the majority of the lives of the residents of the Cotter and Lang housing projects in the Park DuValle neighborhood were improved as a result of HOPE VI (see also Brazley and Gilderbloom, 2007; Gilderbloom, 2008). In Chicago, 63 percent of the residents report that their new housing is in good or excellent condition, and most say that their new neighborhoods have less poverty than their previous neighborhood (Popkin, 2002, 3).

Varady and Preiser $(1998,202)$ found that three-fourths of the Cincinnati Metropolitan Housing Authority (CMHA) residents surveyed living in single-family, scattered-site units, and three-fifths in clustered scattered-site units are satisfied, while only a third of the residents in traditional developments were satisfied. 
These high levels of satisfaction, according to Varady and Preiser $(1998,200-$ 203) were analyzed according to (1) demographic characteristics, such as age, income, education employment status; (2) locational characteristics, such as traditional, clustered scatted-site or single-family scattered site, and whether one lives in the city or suburbs; (3) housing characteristics, such as the quality of the home and the maintenance of the home or unit; and (4) housing attitudes, such as the presence of crime, whether the resident felt safe or not, civic and neighborhood involvement by residents in their neighborhoods, and their involvement in the decision-making process in their neighborhood or community. Varady, Walker, and Wang $(2001,1298)$ also examined the relationship between relocation and housing satisfaction, and found that residents who moved to a nearby housing development were just as likely to be satisfied as those who moved much farther away. Also receiving moderate relocation counseling helped improve housing choice and housing satisfaction.

Homeownership initiatives like HOPE VI are more likely to provide enormous stability in a neighborhood, higher levels of self-esteem and personal freedom, improved quality of life for children, and homeowners are more likely to participate in civic activities and experience greater physical and psychological health and satisfaction from owning a home (Rohe, Van Zandt, \& McCarthy, 2001). According to Varady, Walker and Wang (2001) and Rohe and Stegman (1994), homeowners expressed greater residential satisfaction than those renting and living in apartments. These attitudes of satisfaction among residents come from the personal attitudes of the residents themselves, the characteristics of their own dwelling units, and the physical, geographic, and socioeconomic status of the area. 


\section{HOPE VI Self-Sufficiency Program}

Another part of the HOPE VI program is the case management program known as the Community and Supportive Services (CSS). CSS was formed in response to the Personal Responsibility and Work Opportunity Reconciliation Act of 1996, which helped residents find jobs and transition to better jobs as a means to self-sufficiency through proper counseling and providing information about relocation opportunities, which is a mandatory component of the HOPE VI CSS program (Kingsley \& Corvington, 2000, 4-6; Gilderbloom \& Hanka, 2006).

Much of the literature on self-sufficiency services in HOPE VI has targeted case studies of self-sufficiency programs in HOPE VI and homeownership-related programs around the country in places such as Denver, the state of North Carolina, Louisville and New York City (Rohe \& Kleit, 1997; Ryzin, Ronda, \& Muzzio, 2001; Brazley, 2002; Santiago \& Galster, 2004; Kleit \& Rohe, 2005; Brazley \& Gilderbloom, 2007).

Self-sufficiency services like CSS are an important holistic and comprehensive approach that not only helps residents find and maintain employment and relocate to another housing development, but also address the needs of residents with physical and mental disabilities, older adults and senior citizens, as well as individuals who experienced domestic violence, substance abuse, and those with criminal records and poor credit records (Popkin, 2002; Popkin et al. 2004). Approximately $\$ 714$ million has been budgeted by HUD to CSS programs, which has provided direct services to 45,000 residents, resulting in a median cost of $\$ 7,620$ per resident (Popkin, et al., 2004, 38; Turner et al., 2007, 16). 


\section{Urban Economic Development}

Cities have an important function in our economic system as important agents of economic development. Cities, for the most part, are pivoted on an economic logic that emphasizes that a city must maximize its economic advantage and maximize its wealth by being competitive (Savitch \& Kantor, 2002). Because of a city's structural constraints with capitalism and federalism, cities must be competitive with other cities for economic development (Kantor, 1996). Since cities must compete in the economic marketplace to enhance their bargaining position and maximize their advantage, cities, large or small, must engage in developmental policies aimed toward promoting economic growth (Peterson, 1981; Molotch, 1976; Logan \& Molotch, 1987).

These policies are pursued by the growth machine, particularly by business and political elites, in developing the right political and economic conditions for the success of the city's growth machine (Logan \& Molotch, 1987). Much of the growth pursued by the business and political elites, according to Logan and Molotch $(1987,84)$, are by local circumstance, where "declining cities experience problems that might be erased by replacement investments."

Cities such as Chicago, New York, and Los Angeles, and smaller or medium-size cities like Newport are all guided by the principles of the growth machine (Peterson, 1981; Kantor, 1996; Logan \& Molotch, 1987). Different cities have different resources to bargain for certain developmental outcomes. New York will compete with London and Tokyo and use its bargaining position to bring about development, while cities like Louisville, Raleigh, Memphis or Newport have fewer local resources and must do more to be competitive to bring business and economic development. Through its leadership, a 
city can use its local autonomy and its economic resources to push these development policies in a strategic manner that are consistent with the resources they have at its disposal (Savitch \& Kantor, 2002, 167-168).

Florida $(2002 ; 2005)$ argues that the most effective development strategy in the post-industrial world is developing cities and localities that have a high creative class. In order to entice economic development and urban growth and attract this creative class, cities must develop amenities, which are non-produced public goods and non-market transactions that do not have an explicit price and are restricted to a specific territory that distinguishes it from other territories (Clark, 2002, 497; Green, 2001, 65-66). Florida's analysis measures a positive significant relationship between amenities and the skill level and educational attainment of the workforce $(2005,77)$. If cities commit resources to bring highly-skilled and knowledge-intensive jobs, then those who are employed by these industries are more likely to live in areas with high levels of amenities (Florida, 2005, 77).

Certain cultural and social amenities, such as arts, professional sports franchises, shops and restaurants, will attract a highly diverse group of people, such as minorities, gays, and bohemians, and a highly educated, highly skilled workforce in information technology, the arts, theaters, and music that will bring a critical mass of people into a city or neighborhood to promote growth (Florida, 2002; 2005; Clark, 2002, 497-498). Also, many civic leaders believe that having these amenities will bring middle-class "free-spending visitors" that will help generate investment, increase local tax revenues, and have a multiplier effect in the retail and hospitality sectors (Eisinger, 2000, 317). These amenities can attract businesses in the downtown, and bring tourists and patrons 
with the disposable income to spend at the shops, entertainment, and dining establishments in and around the downtown area.

Amenities such as historic preservation also have contributed to an increase in capital and economic development in cities. Richard Florida (2002) and Donovan Rypkema (2006) have argued on the powerful relationship which exists between historic preservation and economic development. Historic preservation allows for adaptive reuse of buildings, reduces vacancy rates, increases property values, and spawns future rehabilitation (Rypkema, 1994, 63-70). Historic preservation creates jobs and serves as an incubator for small business development and private investment, promotes active community participation through "public/private partnerships" or the main street programs, which can occur at the neighborhood, local, regional, or national level (Rypkema, 1994, 51).

Local, state, and federal resources can be used to preserve historic structures and neighborhoods, such as federal and state tax credits, historic zoning overlays, soft second loans, grants for façade restoration, and the presence of historic preservation offices for towns and cities. These offices have a regulatory design review process for alterations to buildings located within historic districts, and providing educational opportunities to historic property owners (Gilderbloom, House, \& Hanka, 2008).

Ambrosius, Gilderbloom and Hanka (2008) assert that green urbanism is an important trend towards achieving sustainable urban neighborhoods, which is motivated by rising fuel costs, longer commute times, changes in the urban core, and increased ecological awareness. Restoring old historic buildings and homes is an important 
component of green urbanism and living, because according to Donovan Rypkema (2006), "the best green house is an old house."

Much of the literature emphasizes the success of urban economic development strategies and federal housing policies such as HOPE VI. However, little research has focused on the impact of HOPE VI on the overall economic development strategy of a city, and much of the literature has focused, including U.S. Department of Housing and Urban Development (HUD) studies, on many of the successes in the larger metropolitan areas, such as Chicago, Atlanta, San Antonio, New York, Seattle, Columbus, Ohio, and Baltimore (Salama, 1999; Popkin et al., 2004b: Schwartz, 2006; HUD, 1999; HUD, 2000), and less on the medium-sized and smaller cities, such as Newport.

Smaller cities should not be ignored or go unnoticed, because a city, large or small, must maximize their competitive advantage to bring business and economic development to transform city into an economic engine. Too often, studies look at a narrow set of indicators, instead of looking at a broad set of indicators that measure crime, property value increases, the impact on residential quality of life and satisfaction, and business and economic development. This dissertation examines the impact of HOPE VI over an eight-year period, while other studies observe HOPE VI programs for only half the time.

This chapter provides an extensive overview of the prevailing literature in HOPE VI and its key issues, including its impacts and its criticisms, such the satisfaction of former public housing residents who live in HOPE VI neighborhoods and participate in the Community and Support Services program. The next chapter establishes this dissertation's research question, and outlines the hypotheses tested and the different sets 
of methodologies utilized, followed by an analysis in Chapters V, VI and VII that determine whether my variables under study either confirms or refutes each of my hypotheses. 


\section{CHAPTER III \\ RESEARCH QUESTION AND METHODOLOGY}

The last chapter reviewed the current literature on HOPE VI and its impacts on the satisfaction of residents, the impact of scattered-site housing development, and the effects of HOPE VI's Community and Supportive Services and its goals of helping residents become self-sufficient. This chapter outlines the dissertation's research question followed by a set of hypotheses and a section on the different sets of methodologies used in this dissertation.

For this dissertation, my overarching research question is "Has the existence of the HOPE VI program contributed to improving the quality of life and the economic revitalization of the City of Newport?" From this question, I propose four hypotheses:

(1) $\mathrm{H}_{0}$ : The existence of the HOPE VI program contributed to improving residential satisfaction and quality of life of the former public housing residents. $H_{1}$ : The existence of the HOPE VI program did not contribute to improving residential satisfaction of the former public housing residents.

(2) $H_{0}$ : The HOPE VI's Community and Supportive Services (CSS) program led to greater self-sufficiency as measured by education and vocational training. 
$\mathrm{H}_{1}$ : The HOPE VI's Community and Supportive Services (CSS) program did not lead to greater self-sufficiency as measured by education and vocational training.

(3) $\mathrm{H}_{0}$ : The HOPE VI program contributed to an increase in property values throughout the city in HOPE VI and non-HOPE VI neighborhoods. $\mathrm{H}_{1}$ : The HOPE VI program did not contribute to an increase in property values throughout the city in HOPE VI and non-HOPE VI neighborhoods.

(4) $\mathrm{H}_{0}$ : The presence of scattered-site developments in Newport's HOPE VI neighborhoods indicates success compared to the Louisville's HOPE VI neighborhood in Park DuValle.

$H_{1}$ : The presence of scattered-site developments in Newport's HOPE VI neighborhoods does not indicate success compared to the Louisville's HOPE VI neighborhood in Park DuValle.

This dissertation employs a variety of quantitative and qualitative research techniques that uses multiple sources of data to measure the impact of HOPE VI. Many studies in the social sciences have used a variety of qualitative and quantitative research techniques (Molotch, 1976; Wilson, 1987; Logan \& Molotch, 1987; Florida, 2002, 2005; Gilderbloom \& Appelbaum, 1988; Savitch \& Kantor, 2002). 


\section{Case Study}

This dissertation will consist of a case study on the impact of the HOPE VI program on the economic revitalization of Newport. A case study, according to Feagin, Orum, and Sjoberg, relies on "the examination of a single instance of a phenomenon to explore the hows and whys of a problem" $(1991,121)$. The case study is an effective qualitative research method that employs the use of research questions and several data sources to understand a particular entity or social phenomena, such as an organization, community, or social group in its entirety (Schutt, 2004, 420; Savitch \& Kantor, 2002). The case study improves external validity and permits the observer to "assemble complementary and overlapping measures" of a wide variety of data, such as diaries, newspaper reports, correspondences, and personal interviews that can be used to cross check and validate observations as well as claims based on a particular observation (Feagin et al., 1991, 19).

The case study has many advantages because observations of social phenomena can be done by studying them close at hand, and this method also provides multiple sources of information studied over a prolonged period of time. This use of a case study provides a richness and depth of the HOPE VI community that can illuminate and address the broader social context by analyzing the interrelationship of all participants and stakeholders in the community (Schutt, 2004; Babbie, 2004).

\section{Survey Instrument}

I used a survey research instrument that will measure the resident's overall satisfaction with the program services provided to them through the HOPE VI case management services from Brighton Center, Incorporated in Newport. Denise Govan, 
the Family Center Director of Brighton Center, and Mary Kitts, the Brighton Center Community and Supportive Services (CSS) caseworker, provided me a list of 100 CSS families, which represents the number of families active in the CSS program as of June 4, 2007. The list consisted of names of all CSS families with and without telephone numbers and mailing addresses.

The survey's six-point scale ranges from strongly agree, agree, neutral (neither agree nor disagree), disagree, strongly disagree, and no answer. The first section consists of questions aimed at understanding the overall neighborhood and residential satisfaction of the HOPE VI residents with respect to the programs and services offered by Brighton Center's Community and Supportive Services (CSS) and the Housing Authority of Newport (HAN), and whether these programs and services have improved the quality of life for the individuals and families who participated.

This section also measures the changes in the residents' satisfaction of their neighborhood, and the overall health of the neighborhood over the last seven years from the inception of the HOPE VI program in 2000 through 2007 at the end of the CSS program. This section includes questions on whether there are more recreation activities for adults and children, more public transportation opportunities available and better educational and employment opportunities in my new neighborhood as a result of CSS.

The survey also asked questions on community residents and safety and community activity, including social capital, which Putnam $(2000,19)$ defined as "connections among individuals, social networks, and the norms of reciprocity and trustworthiness that arise from them." For Putnam, social capital is important for a 
community because individuals and groups benefit from their contact and involvement in social networks, which includes higher levels of involvement and participation in groups.

The survey also asks questions on safe and affordable housing, including questions on whether residents felt their community is clean and the houses in the neighborhoods are well-maintained, whether there is a presence of crime and drugs in the /neighborhood, and whether the residents felt there were enough opportunities for safe and affordable housing, such as subsidized, Section 8 , and market-rate housing. Questions pertaining to training and vocational opportunities, level of education, presence of drugs, lack of affordable child care, and the confidence in the local housing market are important factors towards measuring and predicting the success of self sufficiency programs (Ryzin, Ronda, \& Muzzio, 2001; Brazley, 2002; Santiago \& Galster, 2004; Kleit \& Rohe, 2005; Brazley \& Gilderbloom, 2007).

The surveys were administered throughout the month of June 2007. In addition, I submitted a study amendment request form to the Human Subjects Protection Program office at the University of Louisville on June 4, 2007 to update and amend our initial approval of our HOPE VI study in 2002. I received approval from their office the following week on June 11, 2007.

The majority of our interviews were conducted over the telephone, through the assistance of Carrie Beth Lasley and Elizabeth McConnell, research assistants who worked on the HOPE VI evaluation grant team. Surveys not administered over the telephone or with residents who did not have a phone number were done in-person or by going door-to-door or to their home, even if that resident had moved outside of Newport. The survey instrument was approved by the Institutional Review Board (IRB) at the 
University of Louisville, which contained a statement, guaranteeing each respondent's anonymity and confidentiality.

In-person interviews with CSS participants were conducted at the offices of Brighton Center, Inc. at 799 Ann Street in Newport. All CSS participants, regardless of having a working telephone number or current mailing address, were notified by Brighton Center staff to stop by Brighton Center's offices to complete the questionnaire. Door-to-door interviews were conducted in Newport on June 25, 2007 with families who live in the south site of the Housing Authority of Newport (HAN) public housing project. The north-site of the public housing projects towards the Ohio River and floodwall were demolished. All the families had moved out and relocated to the south site or to other neighborhoods in Newport or other communities in Northern Kentucky as of September 30, 2006.

The door-to-door interviews were conducted by me, Carrie Beth Lasley and Elizabeth McConnell. Our list of CSS participants provide to us by Brighton Center included the residents who had an address and/or telephone number. Out of these residents we could not reach door-to-door and in-person, we did telephone follow-up calls and returned to Newport two weeks later to complete the interviews.

My survey was approximately six pages in length and was divided into six sections consisting of 55 questions using a six-point scale and five open-ended questions in the demographic section of the survey, which asked the respondents their age, race, level of education, number of persons living in the household, and monthly household income. The results of the survey were manually entered using an internet software survey program (See Appendix A for Survey Instrument). 


\section{Quantitative Statistical Analysis}

Because we do not assume or project that the HOPE VI program exclusively caused the economic rise of Newport, I measured the impact of HOPE VI on other factors of the city's economic revitalization. I collected data between 2000 and 2007 from the beginning to the end of the program from the U.S. Census Bureau, U.S. Department of Housing and Urban Development (HUD), Brighton Center, Inc., and the Housing Authority of Newport (HAN). Property valuation data was collected from the Campbell County Property Valuation Administrator (PVA) that measures the impact of the HOPE VI on the increase in median property values in the HOPE VI neighborhoods of the city, and non-HOPE VI neighborhoods in the city.

In order to measure the impact of property values, this dissertation uses a quasiexperimental design, which assigns subjects to a treatment condition without random assignment of the experimental and control group (Sylvia, et al., 1997; Campbell and Stanley, 1963; Rossi and Freeman, 1985).Whereas non-experimental designs do not have control groups or have a treatment, quasi-experimental designs may use either the treatment or the control group, but do not use random assignment or selection like a pure experimental design (Sylvia, et al.,1997; Campbell and Stanley, 1963; Rossi and Freeman, 1985).

Quasi-experimental designs can show the effects of treatment over a long period of time, which improves its external validity more than with a non-experimental design, but there are less assurances of internal validity than with a pure experimental design (Campbell and Stanley, 1963). Quasi-experimental designs do not deal with causal inferences or relationships and has less control or manipulation over the experiment, and 
can provide a study that can be explained in other situations (Sylvia, et al., 1997, 133134).

This dissertation uses a quasi-experimental design with treatments in two neighborhoods (Liberty Row and Saratoga Street that have HOPE VI developments, and two neighborhoods (East Row Historic District and a neighborhood to the southwest of Downtown Newport) with no treatment and no HOPE VI developments.

Also, I collected data by Kentucky Population Research of the Kentucky State Data Center and the Jefferson County Property Valuation Administrator to analyze changes in median property values from 2000-2006 between the HOPE VI neighborhoods in Newport and the Park DuValle neighborhood, Louisville's HOPE VI neighborhood. I will show the 10 highest and 10 lowest performing neighborhoods in Louisville in terms of property value changes, including the performance of the HOPE VI neighborhood, Park DuValle.

This dissertation includes a regression analysis using three different operationalizations of the dependent variable measuring changes in property values (median neighborhood housing value, raw dollar change, and percentage change), and measure traditional independent variables. I run a standard hedonic neighborhood housing regression with traditional neighborhood predictors (rental percent, percent nonwhite, median housing age, crime rate) and added HOPE VI as a dummy variable to better understand its impact by looking at both standardized and unstandardized coefficients and their significance levels. 


\section{Qualitative Analysis}

In the qualitative portion of the analysis, I conducted a series of qualitative faceto-face interviews with the old public housing project residents through door-to-door and telephone interviews. I conducted individual interviews with key stakeholders and Newport community leaders, including interviews with then Mayor of Newport, Thomas Guidugli; Denise Govan, Director of the Family Center at Brighton Center; Captain Howard Niemeier, Administration Services Division Director for the Newport Police Department; Joseph Condit, Executive Director of the Housing Authority of Newport (HAN); George Darnell, the Housing Authority of Newport's HOPE VI coordinator; Ryan Wyrick, Emily Jarzen, and Bob Yoder with the City of Newport; and Karen Gross Majors, Senior Project Manager for Corporex, the developer of the Ovation project in Newport.

In addition to the original interviews, other qualitative research methods used include public and private document research, which included the original HOPE VI Proposal to HUD, the previous HOPE VI Evaluation Reports (8 volumes), tax and property data from the Campbell County Property Valuation Administrator (PVA), Monthly Business Startup Reports from City of Newport, construction update reports from the Housing Authority of Newport (previously known as Newport Housing Authority), biannual crime reports from Newport Police Department, reports from the developer of the old public housing site, Corporex, as well as photographs to document the before and after effects of the HOPE VI program in Newport.

The next chapter provides an overview of the history of housing in Newport from past to present, including an overview of Newport's history, from its foundation to the 
periods of vice, corruption, and economic stagnation, followed by the history of rebirth, renewal, and revitalization of this small city on the Ohio River. 


\section{CHAPTER IV}

\section{NEWPORT: HOUSING FROM PAST TO PRESENT}

The last chapter established the research question concerning whether the existence of the HOPE VI has contributed to an overall economic revitalization, followed by a set of hypothesis designed to establish the validity of the research question, followed by an outline of the set of methodologies used in the study.

Newport, Kentucky, located in Northern Kentucky at the confluences of the Ohio and Licking Rivers south of Cincinnati, is an important part of the greater Cincinnati metropolitan area, which has an approximate population of two million residents in the metropolitan statistical area (MSA) (See Figure 4.1). According to the 2000 U.S. Census, the population of Newport is 17,048 , a decrease from 18,871 in 1990 , but the July 2006 population estimate for Newport is 15,721 (Gilderbloom \& Brazley, 2003; Kentucky State Data Center, 2006). Newport is the county seat of Campbell County, which has a population of 88,616 , according to the 2000 Census, and has decreased to 86,858 .

Campbell County is the only county to experience a population decrease in Northern Kentucky. Fifty-two percent of the population is female and forty-eight percent is male.

The white population is 92 percent white, six percent black, and two percent Hispanic (U.S. Census, 2000; Kentucky State Data Center, 2007). 
Table 4.1

Demographics of Newport and Campbell County

\begin{tabular}{|c|c|c|c|c|c|c|c|c|c|}
\hline & 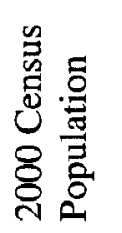 & 总高总言 & 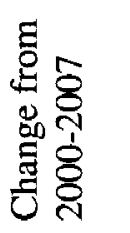 & 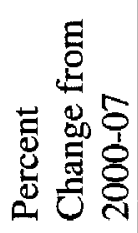 & $\begin{array}{l}8 \\
\frac{9}{3}\end{array}$ & $\frac{\widehat{Q}}{\stackrel{0}{0}}$ & 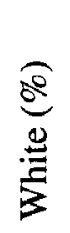 & $\begin{array}{l}\frac{\widehat{Q}}{\underline{u}} \\
\frac{d}{m}\end{array}$ & 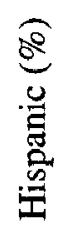 \\
\hline $\begin{array}{l}\text { City of } \\
\text { Newport }\end{array}$ & 17,048 & 15,580 & $-1,468$ & -9.0 & 48 & 52 & 92 & 6 & 2 \\
\hline $\begin{array}{l}\text { Campbell } \\
\text { County }\end{array}$ & 88,616 & 86.858 & $-1,758$ & -2.0 & 49 & 51 & 96 & 2 & 2 \\
\hline
\end{tabular}

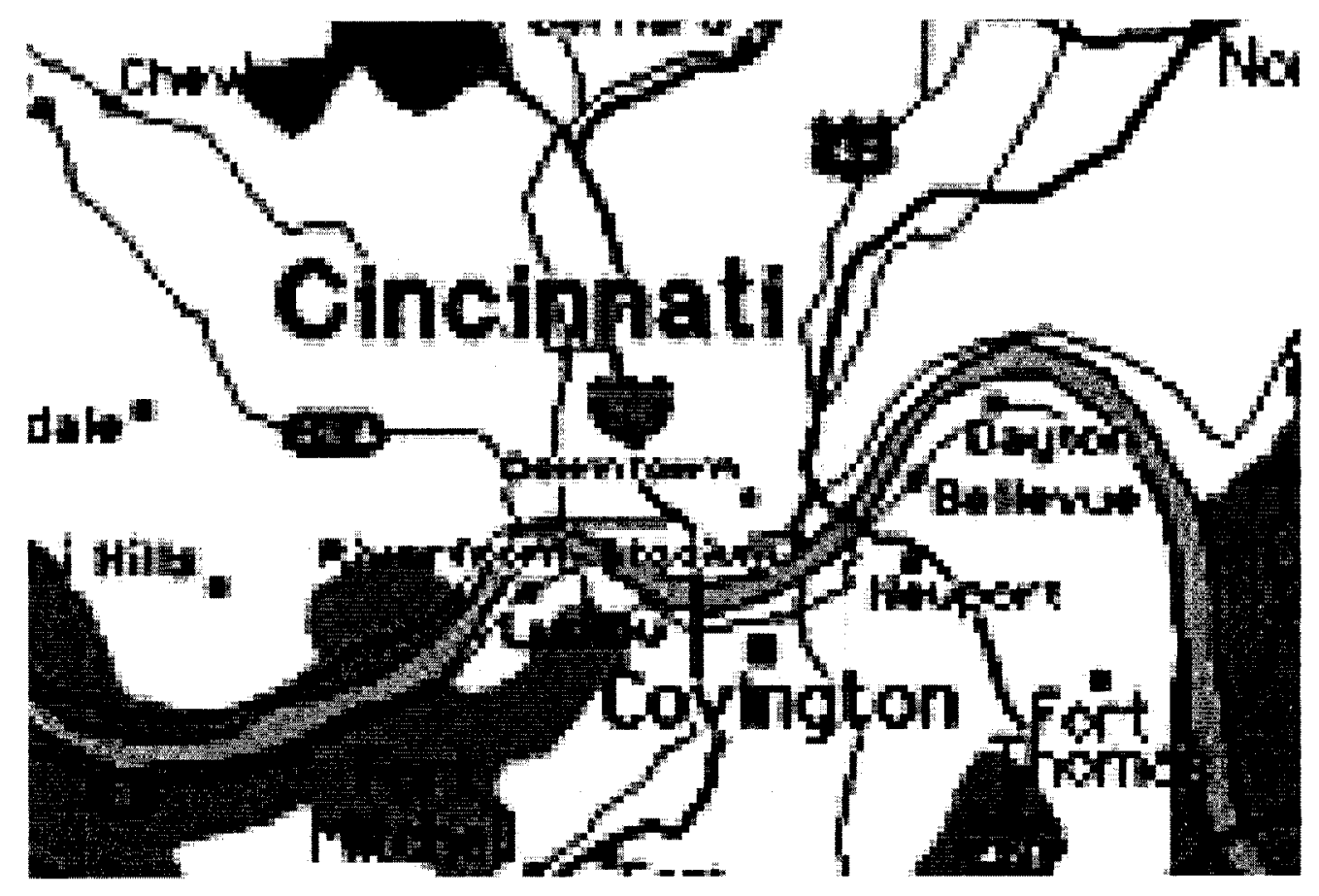

Figure 4.1. Map of the Cincinnati/Northern Kentucky Metropolitan Region.

(Source: City of Cincinnati, OH, http://www.cincinnati-oh.gov/entsrv/pages/-4943-/) 
Newport's history can be traced back to Colonel James Taylor in 1785 and his son, Hubbard, who claimed approximately 1,500 acres on tracts of land comprised of the present day areas of Newport, Bellevue, and Dayton (Clift, Daniels, Fennel, \& Whitehead, 1995, 7-9). This location was chosen because of the Taylor family's vision of a flourishing economic and commercial center at the mouth of the Ohio and Licking Rivers. As Thomas Purvis, editor of Newport, Kentucky: A Bicentennial History $(1995,9)$ noted:

... it would have seemed common sense in 1785 that larger cities would develop along the mouth of the Licking than at modern Cincinnati. The economic future then loomed more promising for the southern shore.... Without a rural hinterland to its north, Cincinnati would lack the economic base needed to sustain a major community. Kentucky's population was expanding rapidly, however, so a city at the mouth of the Licking could be expected to mature into a major transshipment point by handling a heavy volume of agricultural goods headed down the Ohio and Mississippi for sale.

In 1789, pioneer Jacob Fowler was the first permanent settler of Newport with his family, but in 1791, Hubbard Taylor returned to settle and establish the community that would become Newport, named after Captain Christopher Newport, the commander of the first English ship to settle Jamestown, Virginia (Clift et al., 1995, 11-13). The name Newport comes from Newport, Wales, which is located on a river in a coal region. Many of the buildings in Newport, Wales are similar to Newport, Kentucky, but Newport, Wales is more prone to flooding.

The settlement of the city grew at a rapid pace, through the work of Colonel James Taylor's son, James, Jr., who was responsible for surveying the city grid from the Licking River to the West to one block east of Saratoga Street and down to modern day Eighth Street (Clift et al., 1995, 20; Tenkotte, 1989, 32-33). Taylor, along with Jacob Fowler and his wife, helped mark out the first road from Newport to Lexington 
(Tenkotte, 1989, 31). During that time, Taylor applied to the Kentucky legislature to incorporate Newport and Campbell County, and in 1795, Newport's charter was approved and became the seat of Campbell County (Newport History, 2002; Clift et al., $1995,20)$.

Newport expanded rapidly in the 1800 s, along with Cincinnati, known as the Queen City of the West, into a center of trade, industry, and culture through the assistance of the advent of steam-powered riverboats. In its first few decades, Newport had grown into a prosperous town that outgrew its pioneer roots. The new riverboats helped propel Cincinnati to become one of the major premier cities in the United States at the time (www.eastrow.org/history.html). Newport quickly became a military outpost in the nineteenth century, through the establishment of the Newport Barracks, which acted as the chief recruiting center for the upper Ohio Valley. Many prominent officers of the wars of the first half of the nineteenth century, such as the War of 1812 and the Mexican War, spent time at the Newport Barracks (Tenkotte, 1989, 43).

During the 1820 s, the Erie Canal was built to connect Lake Erie and the Ohio River. At the same time, Northern Kentuckians campaigned to have a bridge built across the Ohio River, which would "stabilize the prices of necessities in Cincinnati and would increase trade between the Queen City and Northern Kentucky" and would permit continuous traffic between Cincinnati and Northern Kentucky day and night (Tenkotte, $1989,64-65)$

By 1850 , Newport and its neighbor Covington had conceded defeat to Cincinnati as the "Queen City of the West" (Tenkotte, 1989,2). This is an important acknowledgment to show that Cincinnati had outdistanced Newport and had been 
relegated to the status as a suburb of Cincinnati. This realization enabled Newport to reexamine its capabilities and adopt a new growth and development strategy that would capitalize on its proximity to Cincinnati, while maintaining a distinctive, individual identity (Tenkotte, 1989, 2-3). The economies of Newport and its Kentucky neighbors allied itself to Cincinnati and catered to its residents, which enabled Newport to enjoy its place as a suburban city and an important member of the Cincinnati metropolitan community that was "subordinate to Cincinnati but still retentive of their own statewide urban ambitions" (Tenkotte, 1989, 10).

By the 1890s, Newport had positioned itself to achieve home rule, mostly as a potent weapon against annexation, resulting in the fragmentation of the suburbs through the Cincinnati metropolitan area (Tenkotte, 1989, 9-10). This changed the relationship between the suburban cities and Cincinnati, where Cincinnati embraced its Northern Kentucky neighbors to form a metropolitan identity. However, cities like Newport that enjoyed home rule in the late nineteenth century were not immune to corruption. Vice and gambling ensued in the early twentieth century and became a major part of Newport's quality of life for the next half-century (Tenkotte, 1989).

The Victorian era was Newport's most prosperous period, as shown by the large number of Victorian historic houses that remain in the city today through the establishment of the East Row Historic District. In addition, the city of Newport was home to many German and southern Italian immigrants who relocated from New York and settled in the Newport neighborhoods of Cote Brillante and Clifton in South Newport, otherwise known as Spaghetti Knob (Casebolt \& Ciafardini, 2007, 9). 
Spaghetti Knob was incorporated into Newport in 1935 after 29 years of residents fighting its annexation. The migrants into Spaghetti Knob were the last ethnic migrants to move to the area (Casebolt \& Ciafardini, 2007, 29). St. Vincent de Paul Catholic Church in South Newport was founded in 1916 and catered to the mostly Italian Catholic population of the city. There are many different Italian families that have made up Newport's unique and rich heritage, such as the Pellilo, Peluso, Ciafardini and Guidugli, including Newport's recent mayor, Thomas Guidugli.

In addition to the immigrants, many of the rural migrants from eastern Kentucky in the mid- $20^{\text {th }}$ century experienced massive unemployment and hardship. The cultural differences and the economic realities intensified urban/rural tensions and class warfare between the migrants and Newport residents, many of them initially settling in the city's West end, but eventually moving to other Northern Kentucky suburbs, such as Ft. Thomas, Highland Heights, and the rest of Campbell County (Clift et al., 1995, 247248).

However the sagging economy and erosion of the industrial and manufacturing employment sector, and the stagnating population from 1910 through the Depression era gravitated people towards gambling and vice as an attractive alternative to work (Clift et al., 1995, 248) For much of the early and mid- $20^{\text {th }}$ century, organized crime syndicate bosses such as Pete Schmidt, Albert Masterson, and Ernest A. "Buck" Brady initiated large-scale gambling and prostitution enterprises in Newport, which proliferated during the Prohibition Era (1919-1933) as the best substitute for bootlegging during this period (Clift et al., 1995, 250; DeMichele \& Potter, 2009). 
These gambling and prostitution rings institutionalized corruption and "added a veneer of respectability" to organized crime (DeMichele \& Potter, 2009). Gambling and prostitution had been an important part of the way of life of the people of Newport during this period, including upper class high rollers and middle class average patrons who wanted to be a part of the action (Clift et al., 1995, 248). Newport was becoming the "Sin City of the South" and the Burlesque Capital of the Nation, where many of the same organized crime mafia that controlled the casinos in Havana and Las Vegas controlled the casinos in Newport. As many as 23 adult-entertainment establishments and 80 bars populated Newport's downtown during this period.

One of the early pioneers of the gambling scene in Newport was Pete Schmidt, who ran the Glenn Hotel and Rendezvous at 928 Monmouth Street in Newport, which would later became the Tropicana Club. In 1935, Schmidt bought the Old Kaintuck Castle and reopened it as the Beverly Hills Country Club in Southgate located south of the city. It was a massive and lavish venue that included dancing, vaudeville, theater, big band orchestras, and expansive gambling areas (Clift et al., 1995, 247-248; Yoder, 2005, 119).

The following year, the club burned to the ground, killing the five-year-old daughter of the caretaker. It was rebuilt and reopened in 1937 to much fanfare and visits from local and regional dignitaries and politicians (Clift et al., 1995, 250; Yoder, 2005, 119). Ironically, the rebuilt Beverly Hills Country Club would be burned to the ground again on May 28, 1977, due to overcrowding and faulty electrical wiring (Yoder, 2005, 120). 


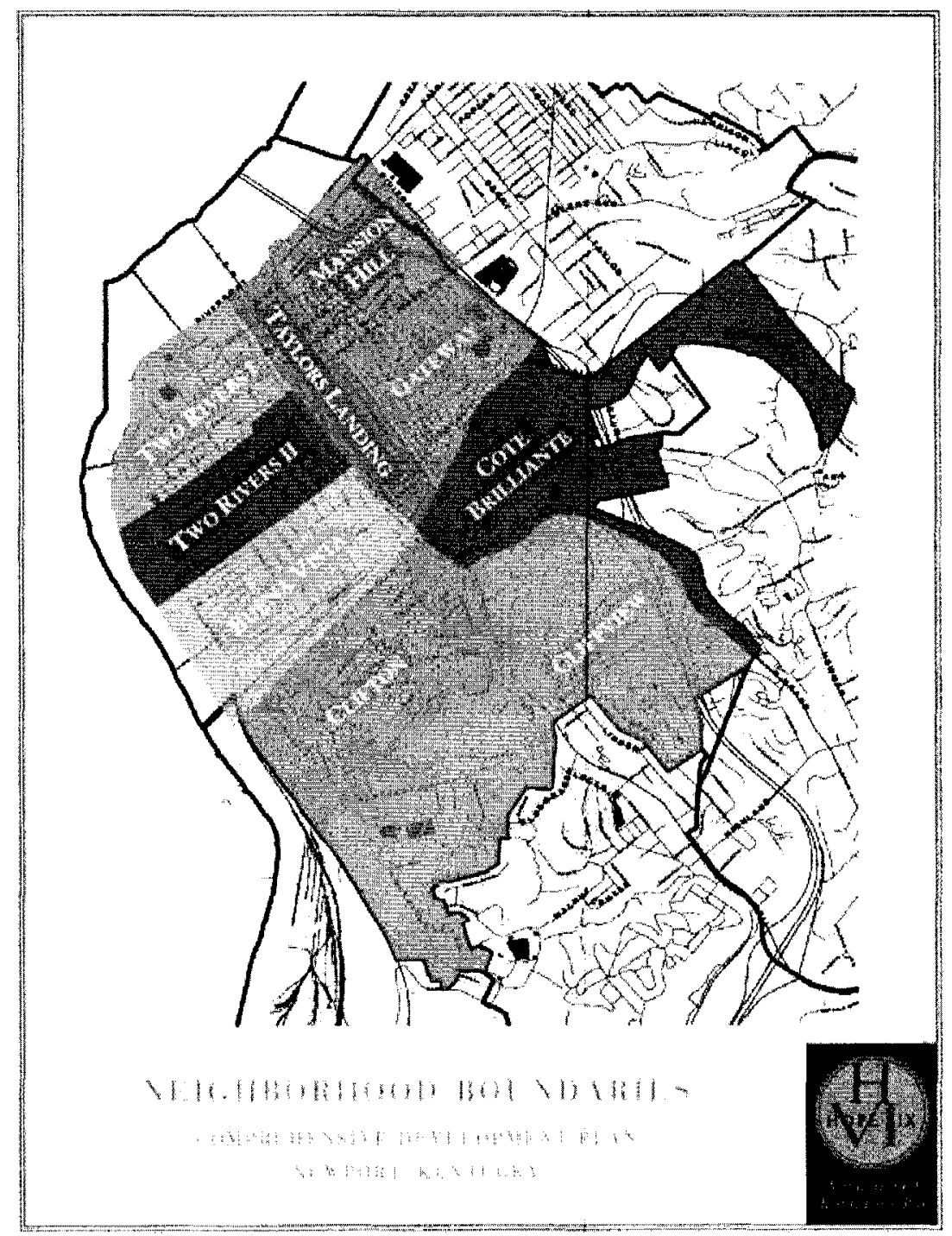

Figure 4.2. Map of Newport's Neighborhoods. 


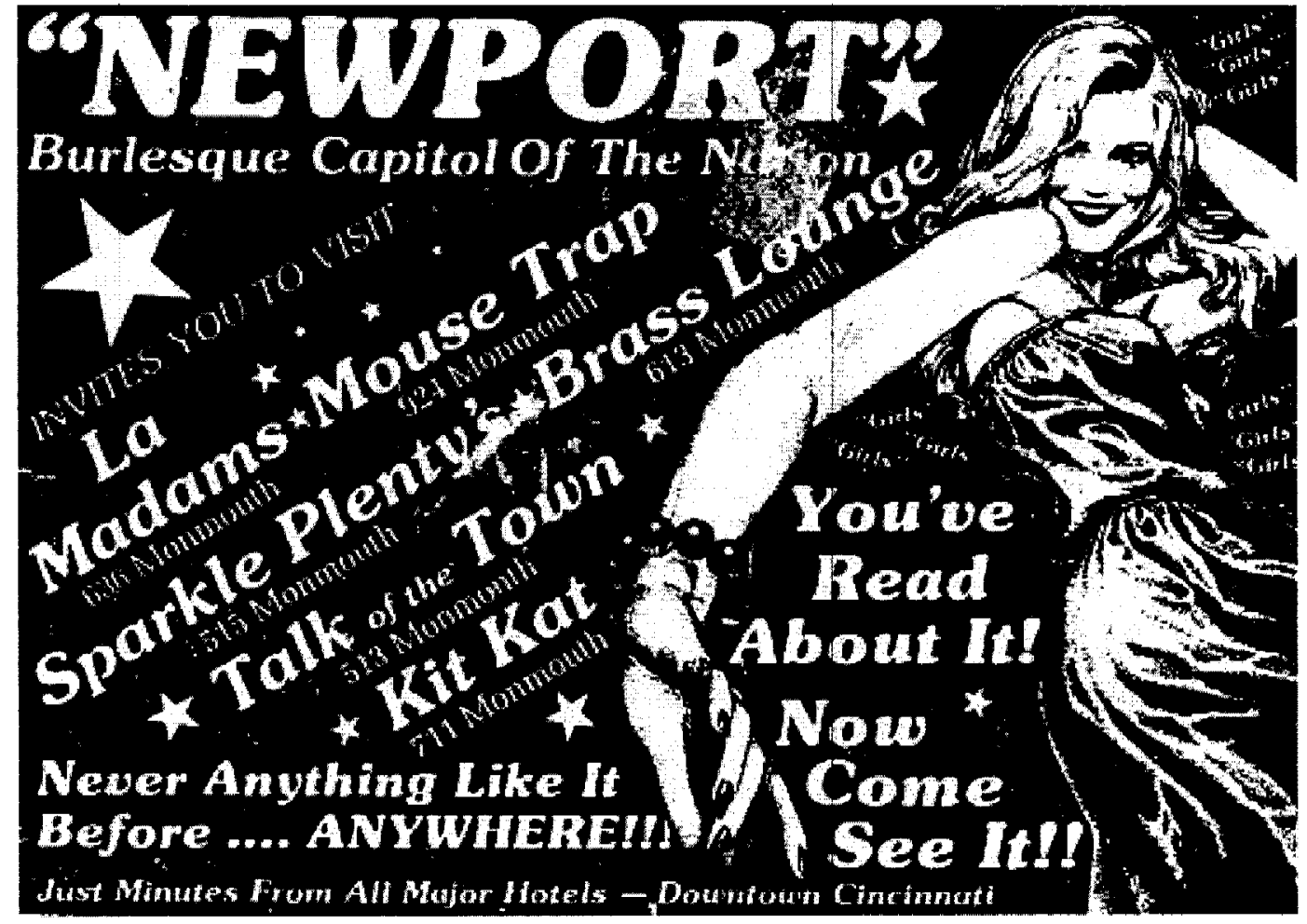

Figure 4.3. An advertisement about Newport as the Burlesque Capital of the Nation.

Today, there are still doubts on the exact causes of the fire, including speculation that it was arson involving members of organized crime. There is enough doubt that survivors of the fire have called on Governor Steve Beshear to reopen the investigation into the causes of what happened at the Supper Club that night. As of early March 2009, Governor Beshear has decided not to reopen the case.

Prostitution has a long history in Newport dating back to the Civil War in the 1860 s, but prostitution was organized by the 1930s and influenced by the city's one-way streets. According to DeMichele and Potter $(2009,12)$, "many residents of Northern 
Kentucky worked across the river in Cincinnati. When residents were going to work, they crossed the Ohio via Monmouth Street. When they returned, they used York Street, a one-way thoroughfare leading back through Newport."1

Other establishments were set up for casino patrons, which included bar-girls, dancers, waitresses, or entertainers at the Frolic, the Silver Slipper, the Merchants Club, operated by Albert "Red" Masterson, the Stardust, and most notably, the famous Tropicana Club at the former Glenn Rendezvous Hotel. In addition to gambling, Newport became a center for bookmaking activity, through "layoff" banks, where bookies would sell some of their betting action to larger and better financed layoff banks, including a layoff bank at Fourth and York Streets. These banks, in turn, would receive reciprocal rights, including a cooperative sheriff and chief of police that would often look the other way in enforcing the law (Goldfarb, 1995, 84; DeMichele \& Potter, 2009).

Some of the most notorious organized criminals in American history have had connections with police, business leaders, and politicians in Newport (DeMichele \& Potter, 2009). Most of the law enforcement officials in Newport received secret payments totaling one million dollars per year for overlooking the illegal activities. Many of these places, including gambling and prostitution houses, were no more than two blocks away in any direction from the Newport police station at Fourth and Columbia Streets (Clift et al., 1995, 255). These organized crime leaders could circumvent the law by being respectable businessmen who served as an integral part of stimulating the city's economy. Clift et al. $(1995,256)$ said: "They were careful to

\footnotetext{
${ }^{1}$ As Hanka and Gilderbloom (2008) argue, the presence of one-way streets hurt downtown businesses, reduce property values, threaten the safety of pedestrians and motorists, make city streets unsafe, and have a disproportionate impact on poor and minority neighborhoods. The presence of crime and vice along with one-way streets only exacerbated the problems plaguing Newport during this time.
} 
spread their orders for liquor, food, flowers, linen, and interior decor around many Newport stores so numerous merchants would see gambling as vital to their economic interests."

While organized crime, vice, prostitution, gambling flourished into the $1950 \mathrm{~s}$, attempts were made to reform and get rid of gambling and prostitution. Ironically, one of Newport's initiators of reform came from The Cleveland Four syndicate led by Red Masterson. This led to the creation of the Newport Civic Association to deal with these issues and field candidates for mayor and city commission under the slogan "Clean Up, Not Close Up" (DeMichele \& Potter, 2009, 13-14). As the decade progressed, little public support was given towards removing organized crime in Newport, which resulted in the diminished credibility of the NCA, especially with the control of the Cleveland Four.

In the late 1950s, local clergy in Newport formed the Social Action Committee (SAC) for the purpose of indicting organized crime leaders and gambling syndicates, but proved to be ineffective (DeMichele \& Potter, 2009, 15). The failure of the Newport Civic Association and the Social Action Committee led to the establishment of the Committee of 500, which consisted of a group of businessmen, ministers and civic leaders who wanted to clean up gambling and political corruption, including bribery and payoffs that were plaguing Newport (Neff \& Harris, 2004, 106).

More specifically, the Committee of 500 called on Kentucky's governor to remove corrupt elected officials who violated the law and failed to enforce the law, and the committee worked to nominate candidates in local political positions (Clift et al., 1995, 261). Despite this move, George Ratterman, a member of the Committee of 500 
and retired professional football player, ran for Campbell County Sherriff and vowed to clean up the "invisible government" and conquer the "forces of evil" in Newport. According to Ratterman, Newport had become a place where "syndicate gambling finds a home, where prostitution flourishes, where officials are known to be corrupt, where alcohol is sold to minors at all hours, and where the illegal narcotics industry has also found a home"(Goldfarb, 1995, 92-93).

However, Ratterman was arrested outside the Glenn Rendezvous Hotel on May 9, 1961, for drug possession and soliciting prostitution. The arrest attacked Ratterman's integrity and credibility by framing and blackmailing him during his campaign to reform and clean up Newport (Clift et al., 1995, 93-94, 98). In his trial on May 17, 1961, Ratterman's defense argued that he was drugged with chloral hydrate by Tito Carinci, the manager at the Glenn Hotel, who would set him up with a prostitute named April Flowers and frame him by hiring freelance photographer Frank Withrow to catch them in the act (Goldfarb, 1995, 90-98). Fortunately, the charges were dismissed after conflicting testimony from the photographer regarding his whereabouts the night of the setup.

After Ratterman's arrest, trial, and dismissal of the charges brought forth against him, Robert F. Kennedy, Attorney General during the John F. Kennedy administration, began a grand jury investigation of organized crime by targeting organized crime's gambling operations and payoffs in Newport (Goldfarb, 1995, 87). Although Kennedy was wary of interfering in local politics and knew little about the case, he pursued the investigation to clean up Newport, a town he said in the Saturday Evening Post in 1963 "long known nationally for wide-open gambling and prostitution ... where a lack of public interest had allowed the cash register of organized crime to clang loudly" (John, 
2004). Robert Kennedy's active involvement in cleaning up Newport's organized crime problem "was critical in allowing the community's embattled reforms to prevail in the early 1960s" (Clift et al., 1995, 259).

After the political shenanigans and maneuvering by organized crime to frame him and after being cleared on all charges during his much-publicized trial, George Ratterman was elected Campbell County Sherriff in the 1961 elections (Goldfarb, 1995, 122). However, all the other reform candidates were defeated by the corrupt pro-vice, progambling incumbents in the city commission (DeMichele \& Potter, 2009, 18).

Nevertheless, he is credited with the beginning of the exodus of organized crime activity, gambling and corruption in Newport in the coming decade (Neff \& Harris, 2004, 109).

Despite the crackdown and public crusade by Robert Kennedy to dismantle the organized crime operations in Newport, the vice and prostitution still lingered further stigmatizing the city for years as a center of sin and vice. This continuing problem resulted in the further deterioration of the central business district, particularly Monmouth Street, which was populated by dozens of strip clubs, pornographic theaters, and go-go clubs (Clift et al., 1995, 265, 271). During the 1960s and 1970s, little business and economic activity occurred in Newport. The deteriorating economy of the city caused a shrinking of the middle and professional class, resulting in the third highest white underclass among cities in the United States (Clift et al., 1995).

For the most part, the Newport city government was ill-equipped and overwhelmed to handle the city's mounting problems, such as curbing unemployment and poverty. The liberals who dominated city politics since the 1950 s continued to operate in the old patronage political system that was outdated and lacked the vision, 
competence, and wherewithal to rebuild and revitalize the city, and took little action to remove the adult entertainment industry from Newport (Clift et al., 1995, 284). Many of these politicians, including former mayor Johnny Peluso, and other Newport city commissioners were found guilty of corruption, perjury, conspiracy, extortion, bribery, forgery and theft (Clift et al., 1995, 283).

Irene Deaton was elected Mayor on a reform platform in 1979 , after serving two terms on the Newport City Commission. The old guard eventually lost in 1981 to the slate of candidates from the Newport Political Action Committee (NEWPAC), an organization created to finance, endorse, and campaign for a reform ticket. The NEWPAC slate of candidates was elected in the following election in 1983 (Clift et al., $1995,284-286)$.

The reform minded NEWPAC officials passed several ordinances, including an ordinance outlawing nudity in places selling alcohol, and stricter zoning regulations to block additional strip clubs, as well as enforcement of vice and prostitution laws. This included an ordinance in 1991 that imposed a $\$ 5,000$ adult entertainment fee for establishments with a liquor license, as well as a comprehensive ban on total nudity (Clift et al., 1995, 287). Despite these reforms against adult entertainment and vice in the city, little progress was made in the 1980 s and early 1990 s to clean up the city and its image until the election of Thomas Guidugli, who was mayor of Newport for 16 years, from 1992 to 2008 .

As this dissertation presents, former Mayor Guidugli's determined leadership as mayor for the past 16 years, and his willingness to seek out federal grants through HOPE 
VI, and the vision towards cleaning up Newport's checkered past have been key in the renewal, restoration, and revitalization of Newport.

\section{Historic Preservation in Newport}

Newport, Kentucky, contains a wealth of significant historic structures and local preservation efforts have been successful for a variety of reasons. The city of Newport has embraced historic preservation through an active historic preservation office that offers resources for historic property owners, and administrates a design review process for any alterations to historic sites. The Newport Historic Preservation Office also has a preservation reference library available for public use, as does the Newport Public Library. The city of Newport's website also contains links to various preservation journal articles and other websites.

The success of preservation efforts in Newport also can be attributed to redevelopment efforts on the riverfront, local incentive programs for historic preservation efforts, and state tax credits. Historic preservation practices have been a contributing factor to new capital flowing into this 200-year-old city. Richard Florida (2002) and Donovan Rypkema (2006) both focus on the powerful relationship between preservation and economic development. One such development is the $\$ 1$ billion dollar Ovation retail and condominium complex that overlooks the Ohio River next to Newport on the Levee.

In addition, the HOPE VI program has introduced housing with historic elements that imitate the brick row housing of yesterday and are positioned alongside recently restored historic housing, particularly on Saratoga Street near the East Row Historic

District. Fifty-four percent of Newport's housing stock was built before 1939, and 78 
percent was built before 1959 (U.S. Bureau of the Census, 2000). There are five historic districts listed on the National Register of Historic Places in Newport, the largest of which is the East Row Historic District. This district's boundaries are $11^{\text {th }}$ Street to the south, Third Street to the North, Oak Street to the east, and Saratoga Street to the west.

The East Row District is significant for its quality and quantity of late 19th century/early 20th century residences, encompassing approximately 1150 acres and 984 buildings. It is the second largest historic district in Kentucky, second only to the Old Louisville neighborhood. This neighborhood currently is undergoing considerable revitalization, where twenty years ago it was in a state of severe decline.

Newport has a number of local incentive projects that benefit historic preservation, including sales tax exemptions for building materials, a property assessment moratorium, and local paint partnership programs. Businesses and properties located in the historic core are exempt from state sales tax on building materials and supplies used in the rehabilitation of the property. In addition, business owners are able to defer the added value of improvements of structures twenty-five years or older from the taxable assessment of their property for a period of five years (Gilderbloom, House, \& Hanka, 2008).

Properties located within the East Row and Monmouth Street historic districts are subject to design review guidelines, which include rules about recommended paint colors, fencing, alternative materials, demolition, and new construction. Property owners are required to obtain a certificate of appropriateness for any exterior updates or additions to their buildings (Gilderbloom, House, \& Hanka, 2008). 


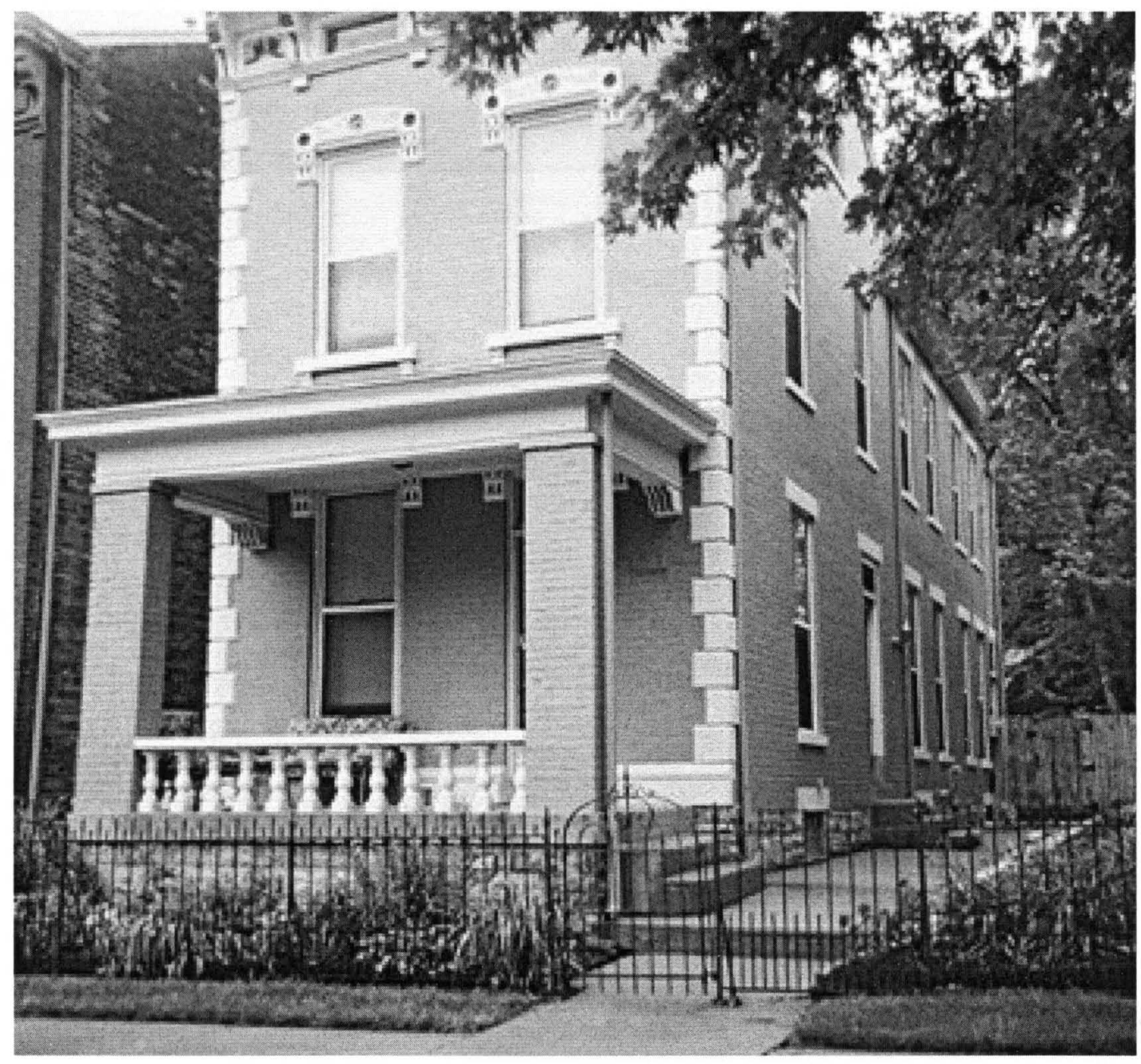

Figure 4.4. Historic Home in East Row Historic District, Newport, KY. 
Changes to historic properties are not enforced as strictly as Louisville or Lexington. The East Row District and the Main Street corridor are protected primarily by zoning restrictions. The only building with National Landmark status (and therefore increased restrictions) is the Carnegie Library located on Monmouth Street.

Main street businesses in Newport do not rely heavily on tourism dollars. Most of them are small businesses that primarily serve local community members. The majority of these businesses have been in operation for almost 100 years and sells high quality and unique goods. Although many of these local businesses close around 5 p.m., the main objective in the revitalization of Monmouth Street is to bring in more nightlife to the area.

Part of Newport's success in preservation is due to its willingness to allow adaptive reuse of historic buildings within appropriate guidelines. This includes the opening of an ice cream shop at Fourth and Monmouth Streets, and the opening of the Hannaford Suites Hotel, a $19^{\text {th }}$-century building which was originally the old Notre Dame Academy, which has been converted into condominiums.

Local architecture firm Brandstetter Carroll, Inc. has performed a master plan for streetscape development of eight blocks of Monmouth Street, which includes improvements to sidewalks, curbs, curb ramps, lighting and related street amenities. Newport city leaders have been looking at various ways to respond to increased traffic and revitalization of the main street, including the conversion of Monmouth Street from a one-way north traffic flow to a two-way street.

State tax credits also have benefited the preservation community of Newport. Since its inception in 2005 , over 89 projects have been completed statewide. Eligible historic properties receive a 20 percent tax credit for improvements to income-producing 
properties and 10 percent for residential buildings built before 1936 ( 73 years or older). Newport's historic preservation officer, Emily Jarzen, believes that there has not been a dramatic increase in preservation efforts since the state tax credit program was enacted. She states that the three million dollar cap is far too little, and the problem is that there is no assurance of receiving funds when applying to the program (Emily Jarzen, personal communication, August 1, 2007). Funds are not accessible enough and the cap should be raised substantially in order to make the program available to a wider population.

One successful state tax credit project in downtown Newport is the Marx-Cromer property, a three-to-four story former furniture warehouse building being rehabilitated to provide 50 market rate rental units and approximately 20,000 square feet of office and retail space. Although Marx-Cromer was initially planned to be a HOPE VI development, a private developer took over the project. Without historic preservation tax credits, the building's purchase price would not have been unreasonable, and the building would have been slated for demolition. Leases were scheduled starting in September 2007 for about $\$ 1$ per square foot, or about $\$ 800$ per month rent. The reuse of historical properties like Marx-Cromer will bring character back into the urban area while preserving the historic landmarks of the city, and provide an incubator for businesses through mixed-use with residential and office space (Gilderbloom, House, and Hanka, 2008).

There are several historic districts in Newport on the National Register of Historic Places. In order to be considered for placement on National Register of Historic Places, the State Historic Preservation Office must nominate the neighborhood or district and must meet the National Register Criteria for Evaluation, which examines the property's 
age and integrity (is it old enough to be considered historic and does it look the way it did in the past), and whether the property is significant, through its association with important events, and activities, and developments, or lives of people in the past (National Register of Historic Places, 2009). The York Street Historic District is located west of Monmouth Street, while the East Row Historic District in Eastern Newport is approximately three to four times the size of Monmouth Street shopping district, encompassing businesses and several HOPE VI developments.

According to Emily Jarzen, businesses located in historic districts provide more social and economic cohesion, stabilize property values and create great selling points for prospective historic district business owners, while taking advantage of tax credits offered in historic districts (Emily Jarzen, personal communication, August 1, 2007). Businesses and developers have an array of choices in the building stock within historic districts. These historic districts make urban areas unique and attract diverse businesses such as funeral homes, restaurants, shops, bars and boutiques. Jarzen also emphasized the need to protect more areas of historical significance in the city. One or two additional historic districts are likely to be created in Newport within the next five to ten years. Jarzen believes that HOPE VI residential developments located in historic districts have the potential to be properly maintained because of the strict codes and enforcement in place for preserving the historic districts of Newport (Gilderbloom, House, \& Hanka, 2008; Gilderbloom, Hanka, \& Lasley, 2008).

Through the HOPE VI program, the richness of Newport's historic preservation district has provided the city and the Housing Authority of Newport the opportunity to introduce historic style housing that imitate the brick row housing of the past and 
positioned alongside recently restored historic housing throughout the city. The following section provides an overview of the HOPE VI program in Newport over the last eight years, from its inception to the development of its various phases, including a progress report on the project.

\section{Overview of Newport HOPE VI}

The Housing Authority of Newport (HAN), formerly the Newport Housing Authority, received a grant of $\$ 28.4$ million from the U.S. Department of Housing and Urban Development in 2001 to undertake the HOPE VI program. The initial agreement required HAN to convert and replace 202 severely distressed public housing units with 325 mixed-income units throughout Newport, Liberty Row, Saratoga Street, Corpus Christi, City Wide, and Central Housing. A major goal of the Newport HOPE VI program was to use the "tightly-knit, historic fabric of the city to its advantage by planning for infill housing, rehabbing of historically notable structures and converting formerly industrial sites into attractive, affordable housing" (Gilderbloom et al., 2002, 96-97).

The developers, Pennrose Properties, Inc., from Philadelphia signed the development agreement with the Newport Housing Authority on September 30, 2002 (Gilderbloom et al., 2004). In its application to HUD for the HOPE VI grant, the Housing Authority of Newport established several principles for management of the HOPE VI developments, including:

- The encouragement of active resident councils that communicate regularly with management;

- Strict enforcement of lease provisions, especially the one-strike provision; 
- Requirements that HOPE VI public housing residents be employed or participating in the CSS programs;

- Excellent standards of property and housing maintenance and provisions of opportunities for residents to learn home maintenance and repairs; and

- Specific commitment to helping motivate public housing residents to become homeowners (Housing Authority of Newport, 2000).

The revised program schedule submitted to HUD for approval on August 1, 2003 (Planning Schedule, revision 3a) was the result of changes in the development of the existing sites (Gilderbloom \& Roosa, 2004). The new agreement required 325 units, 192 rental units and 133 homeownership units, to be completed by June 30, 2009. The 192 rental units are more than the 150 agreed upon between the housing authority and HUD after HAN submitted a revised revitalization plan (The Housing Authority of Newport Planning Schedule, revision 3a) to change the total in August 2003. Of the 133 homeownership units, 65 of them are the Soft Second Mortgage (Community Investment Partnership Program) units, and the remaining 68 homeownerships units (new construction and historic rehabilitation) are being developed by HAN. Many of these designs in Liberty Row, Saratoga Street and Corpus Christi will consist of single-family dwellings, townhouses, clustered duplexes, and multi-unit apartments, which will be available for rental and use of Section 8 vouchers. New housing units will be available on the open housing market and to housing authority residents who participate in the CSS program (Gilderbloom et al., 2002, 96-97; Gilderbloom \& Brazley, 2003, 57).

All of the 201 families that lived at the old Newport Housing Authority north-site were relocated as of June 30,2006 . The demolition of the north-site housing units was completed on November 30, 2006. The offices of the Housing Authority, once located at the north-site of the public housing at the river and floodwall, have been relocated to a newly-renovated historic building on 30 East Eighth Street near Monmouth Street. 
According to George Darnell, HOPE VI Coordinator for the Housing Authority of Newport (HAN), and Linda Fields, Deputy Director for HAN, approximately $75 \%$ of the populations living in both the HOPE VI developments and Newport's total public housing are stock are white, and $25 \%$ of the HOPE VI and total public housing population is African-American and minority (George Darnell, personal communication, April 7, 2009; Linda Fields, personal communication, April 8, 2009).

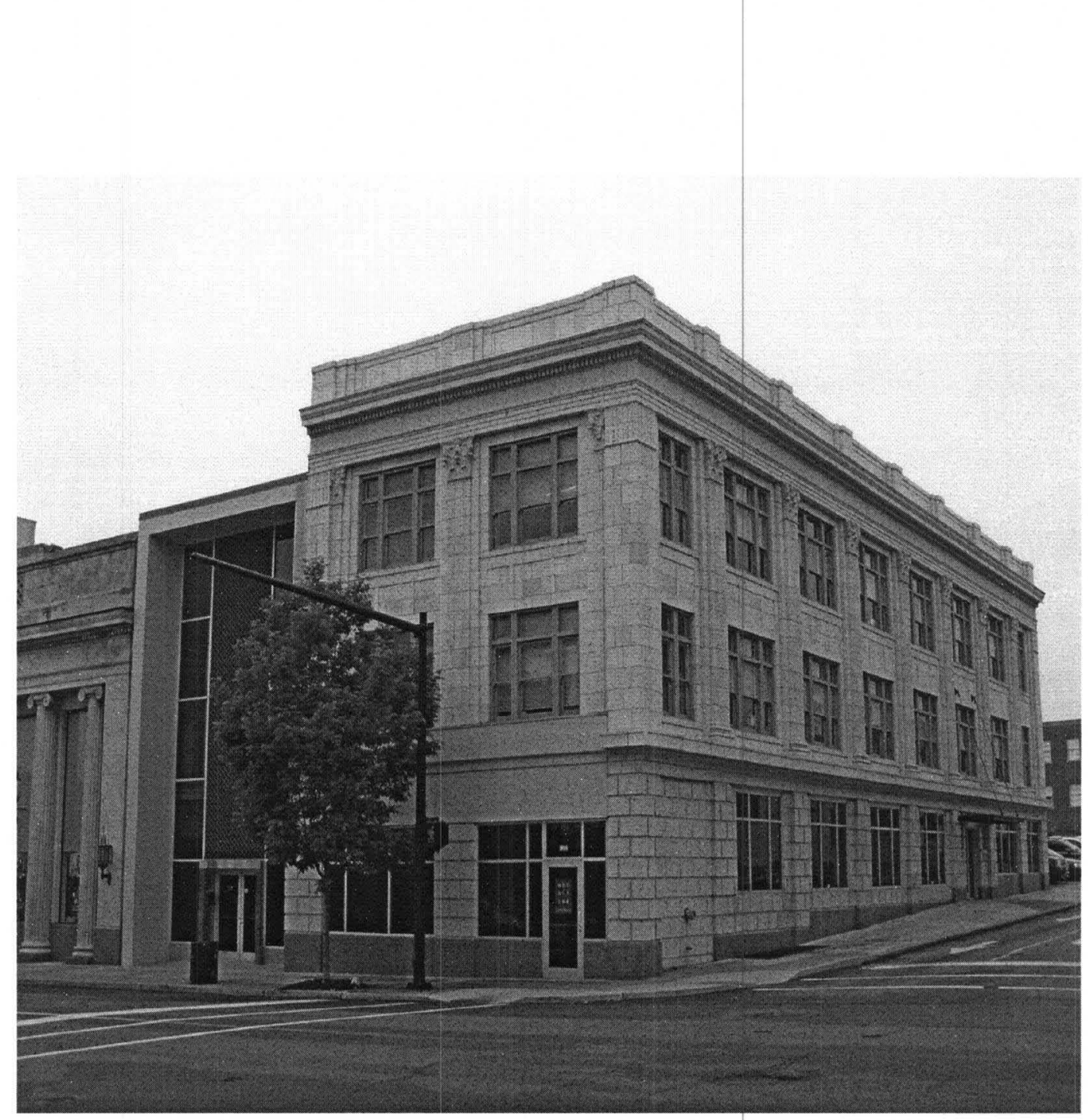

Figure 4.5. New Headquarters of the Housing Authority of Newport. 


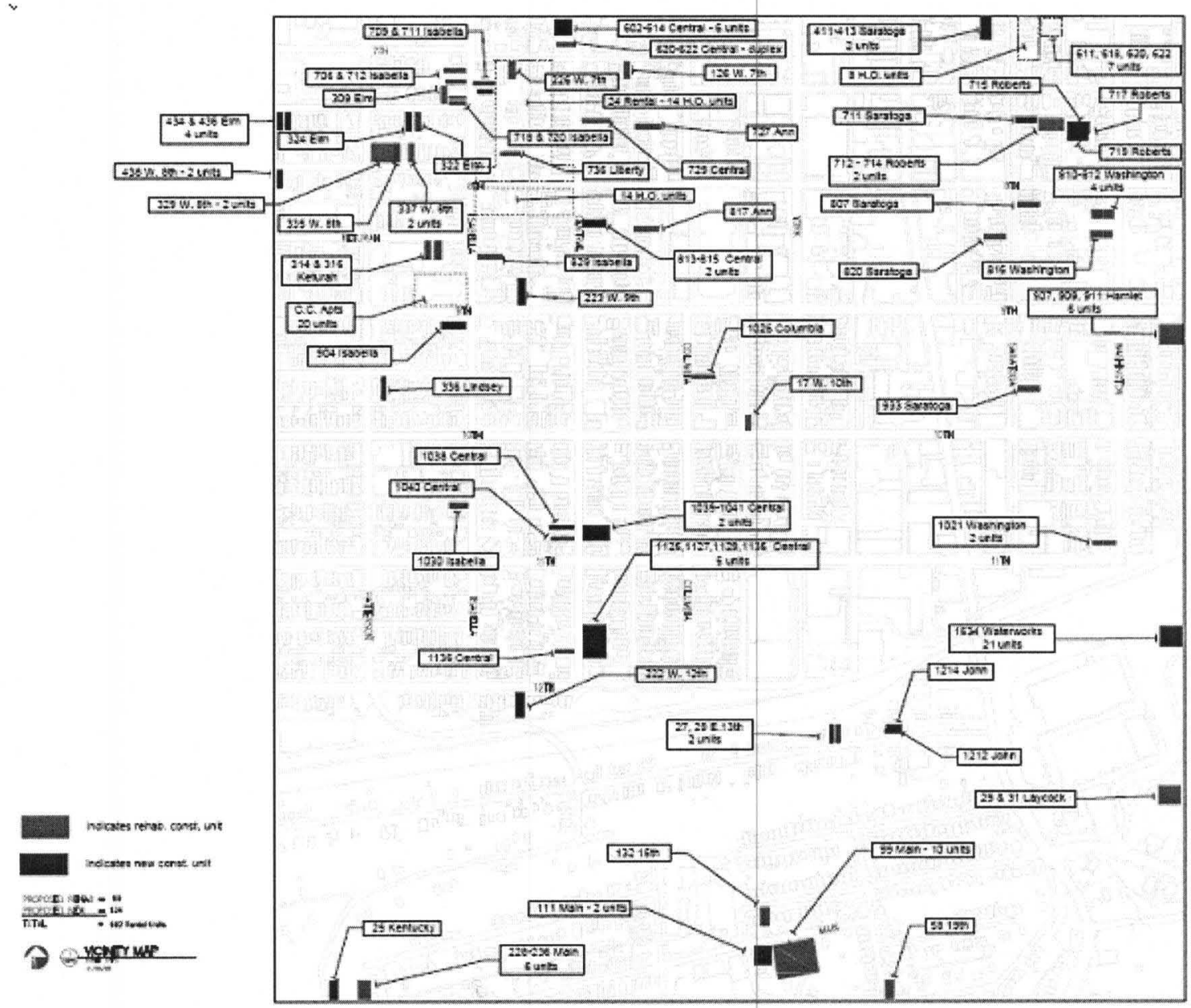

Figure 4.6. HOPE VI Developments as of August 14, 2008. (Source: Housing Authority of Newport) 


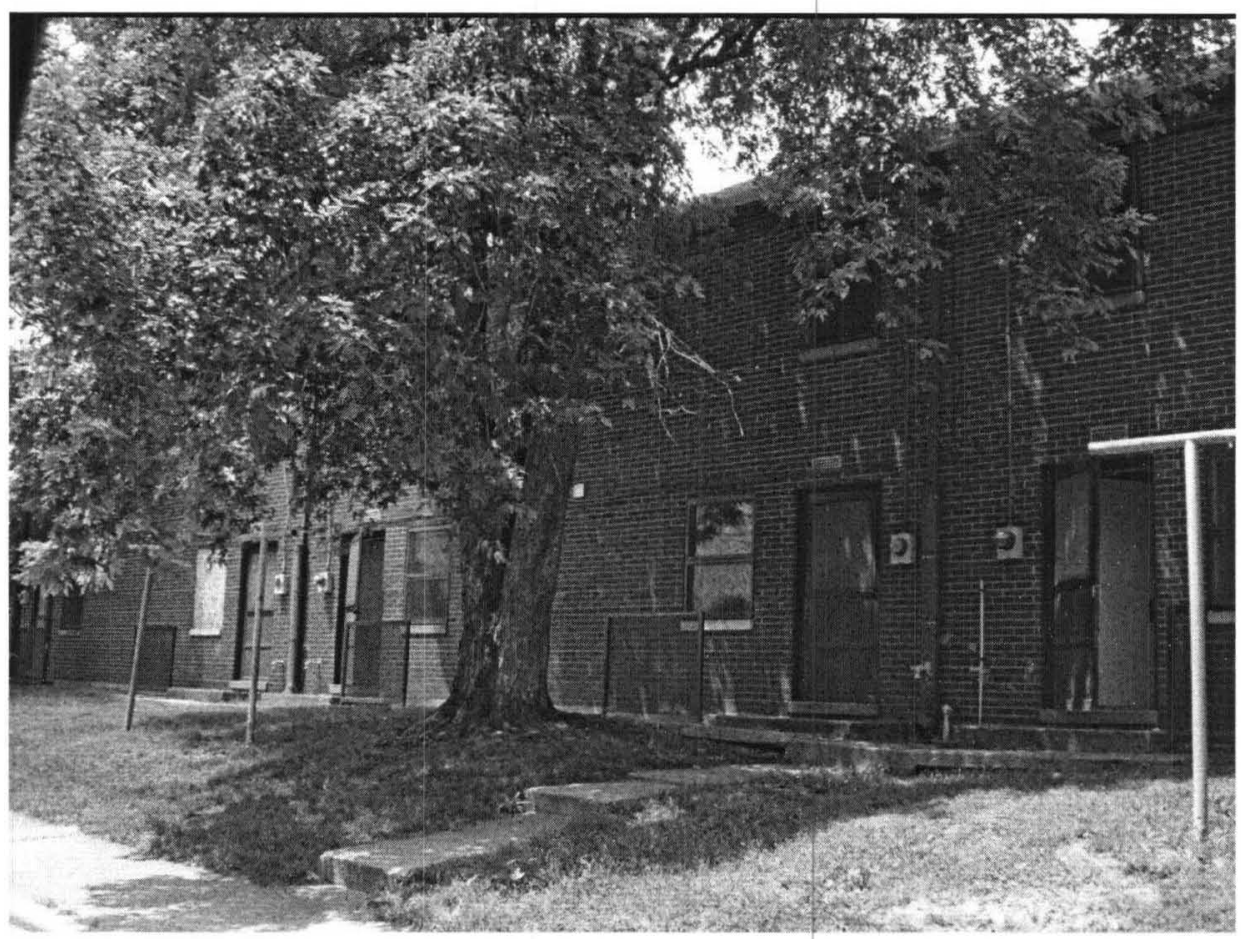

Figure 4.7. Housing Authority of Newport Old Public Housing Site.

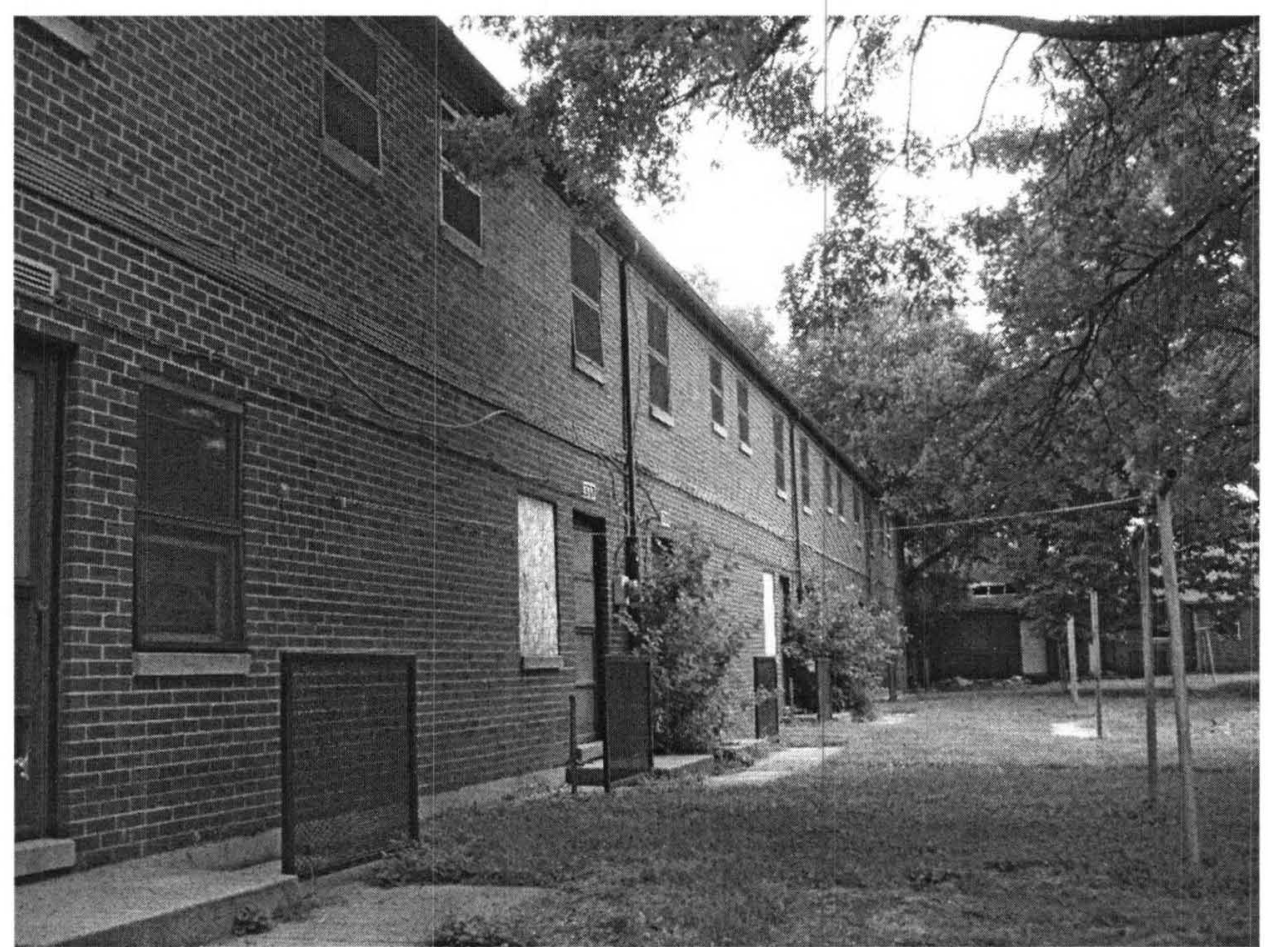

Figure 4.8. Housing Authority of Newport Old Public Housing Site. 


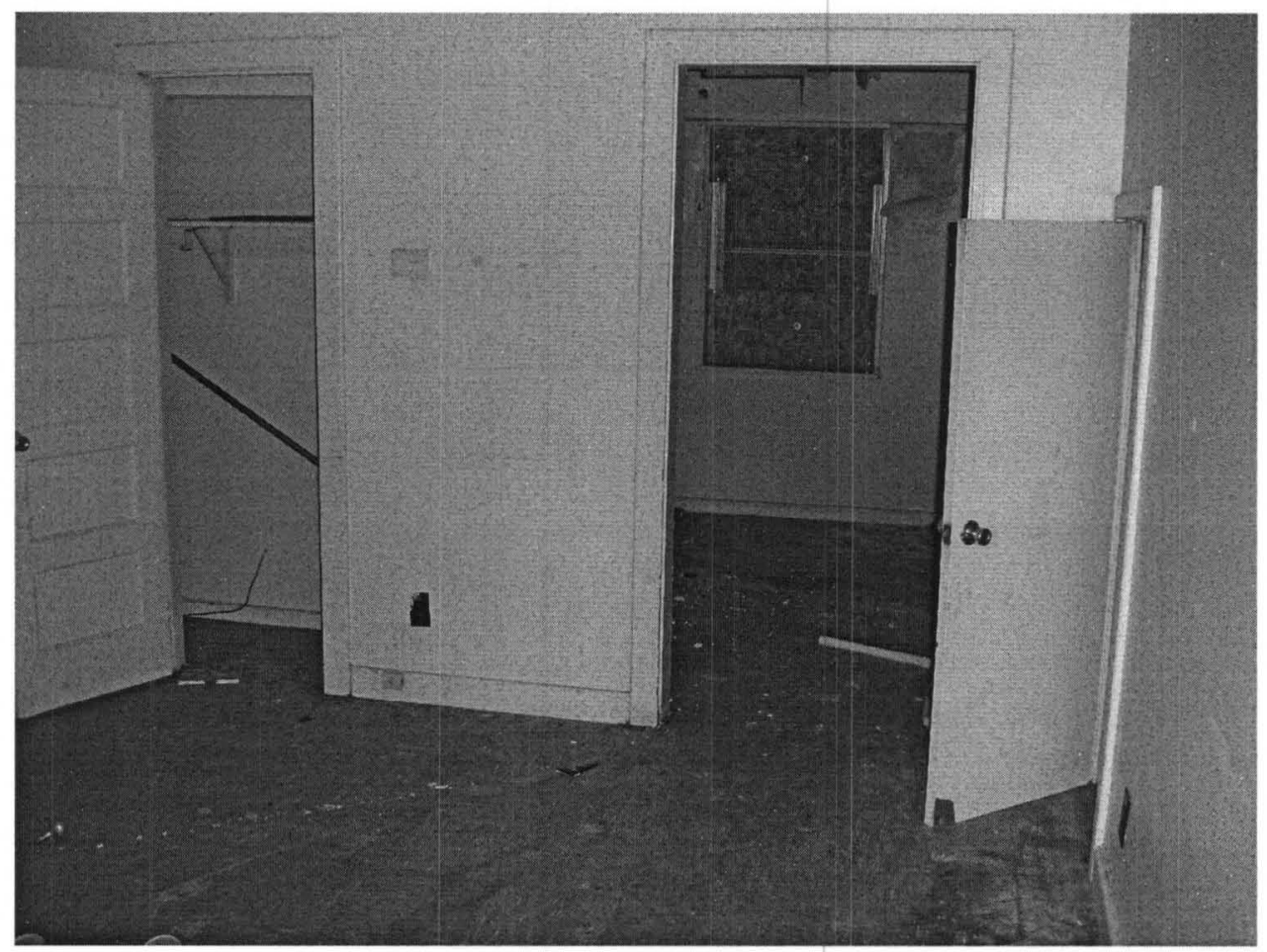

Figure 4.9. Old interior of Public Housing Units.

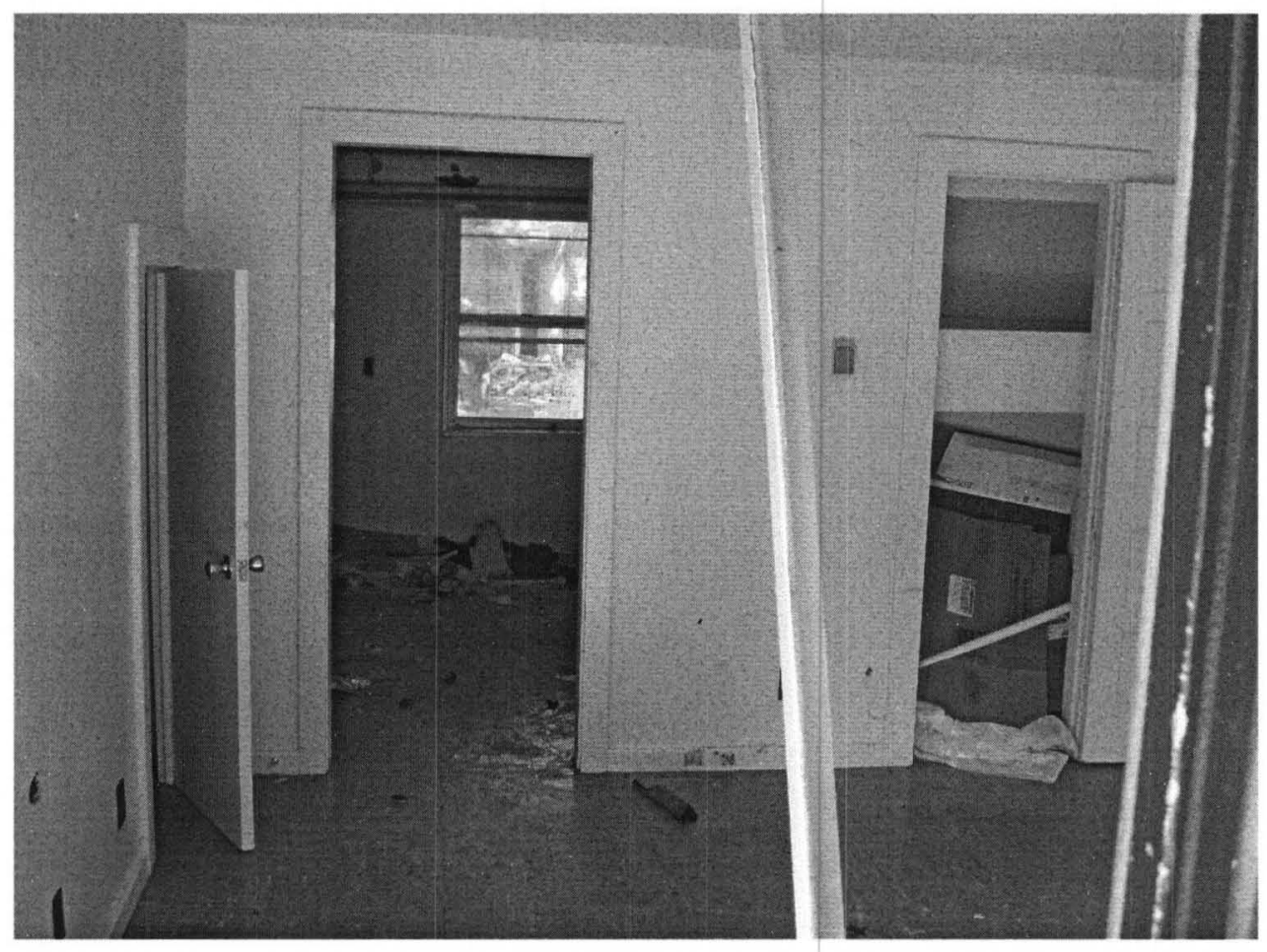

Figure 4.10. Old interior of Public Housing Units. 


\section{Corpus Christi Apartments}

Corpus Christi Apartments project is a 20-unit, nine percent Low Income Housing Tax Credit (LIHTC) project completed on January 15, 2006. Developers qualify for the LIHTC, good or 10 years, if a specific proportion of units are for lower income households and these rents are at least 30 percent of the adjusted median income (AMI) for the household (HUD User, 2003). The twenty units in Corpus Christi are tax credit units (50 percent of AMI) designed for senior living. The units range from 628 to 767 square feet and have remained at 100 percent occupancy since they opened thanks to a marketing plan instituted by the Housing Authority of Newport (HAN), which acts as the property manager (Figures 4.11-4.16).

HAN received an award from the Newport Historic Preservation Committee on the Corpus Christi project. According to George Darnell, the HOPE VI coordinator for HAN, Corpus Christi was submitted in a national historic renovation competition by Cole and Russell Architects, the architectural firm who designed Corpus Christi. 


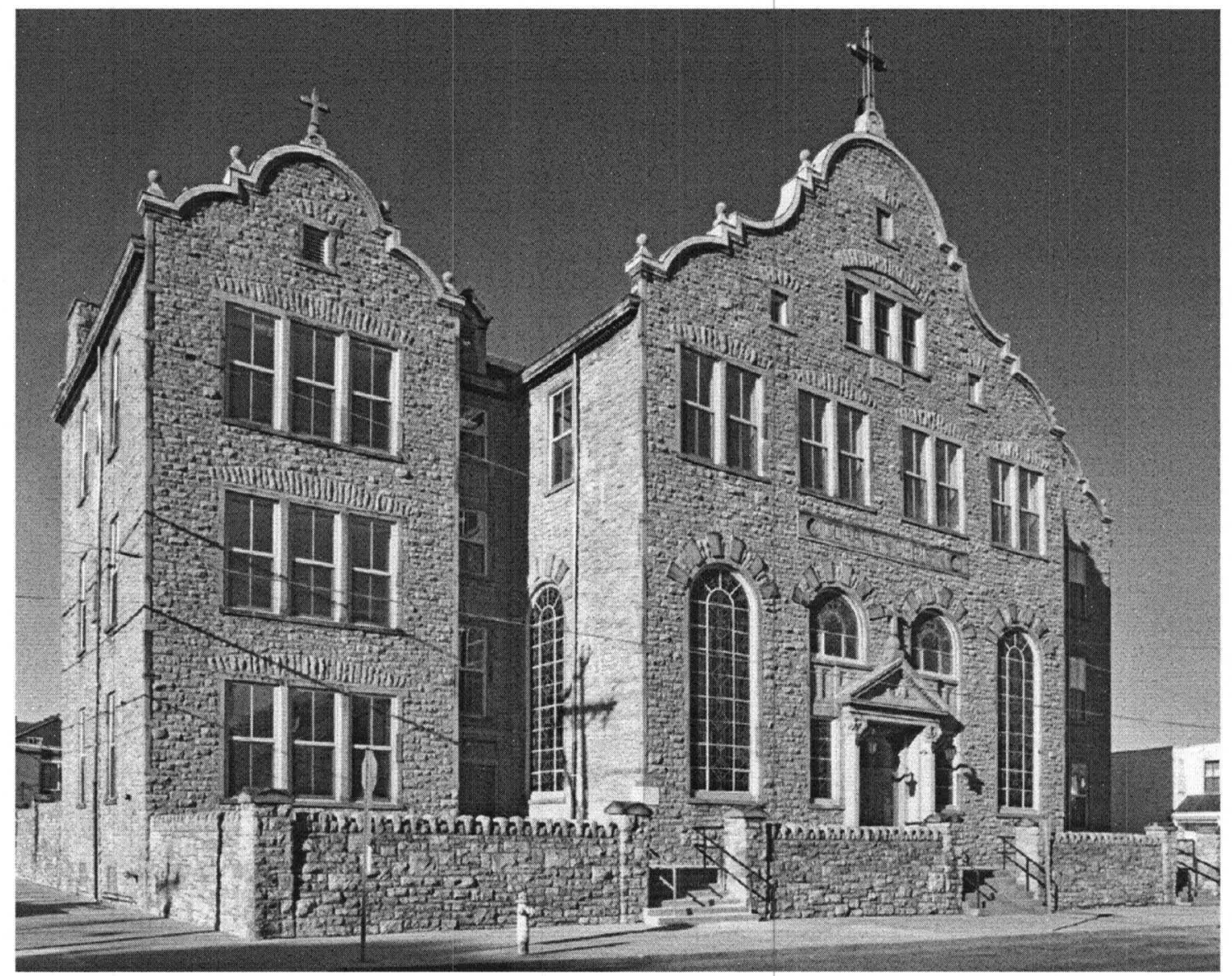

Figure 4.11. Corpus Christi Apartments. 

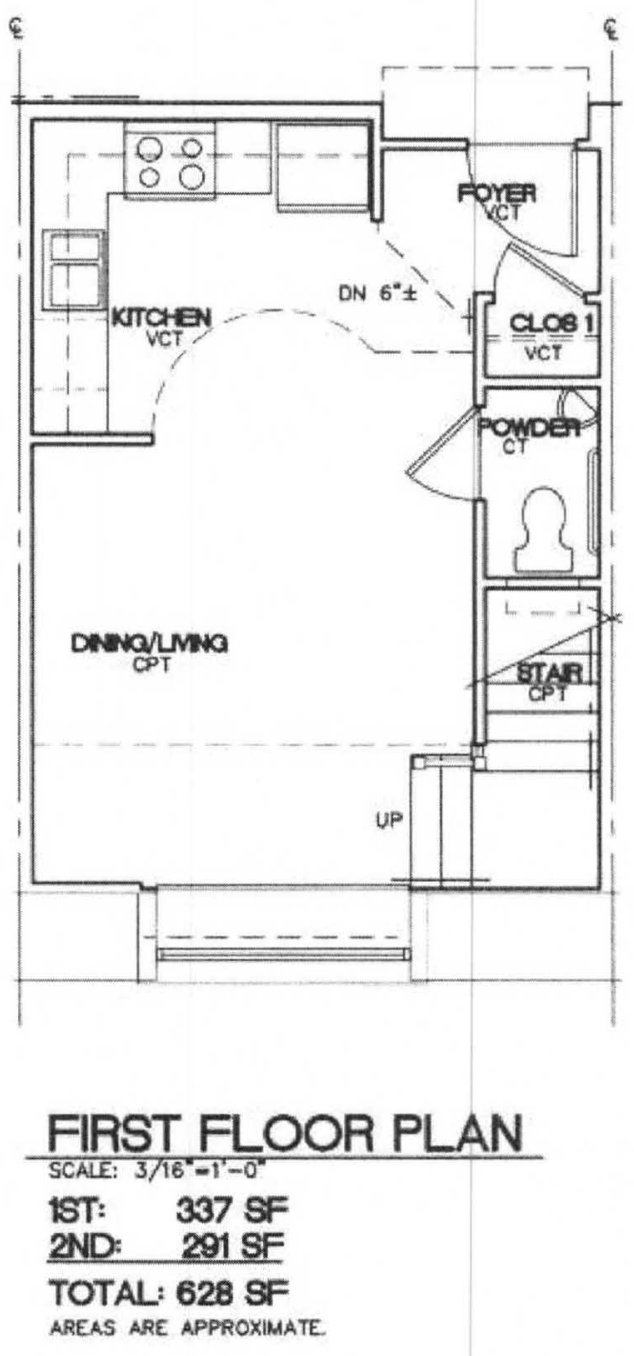

\section{CORPUS CHRISTI APARTMENTS NEWPORT, KY}

\section{TYPICAL NAVE TOWNHOUSE UNIT UNIT A - FIRST FLOOR}

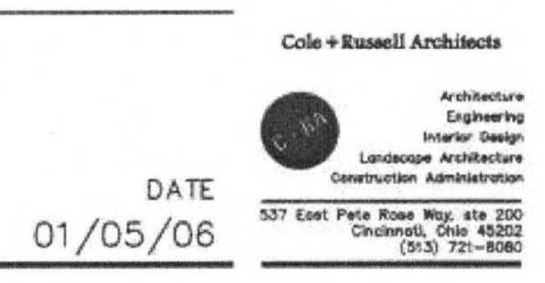

Figure 4.12. First Floor Plan, Corpus Christi Apartments. 

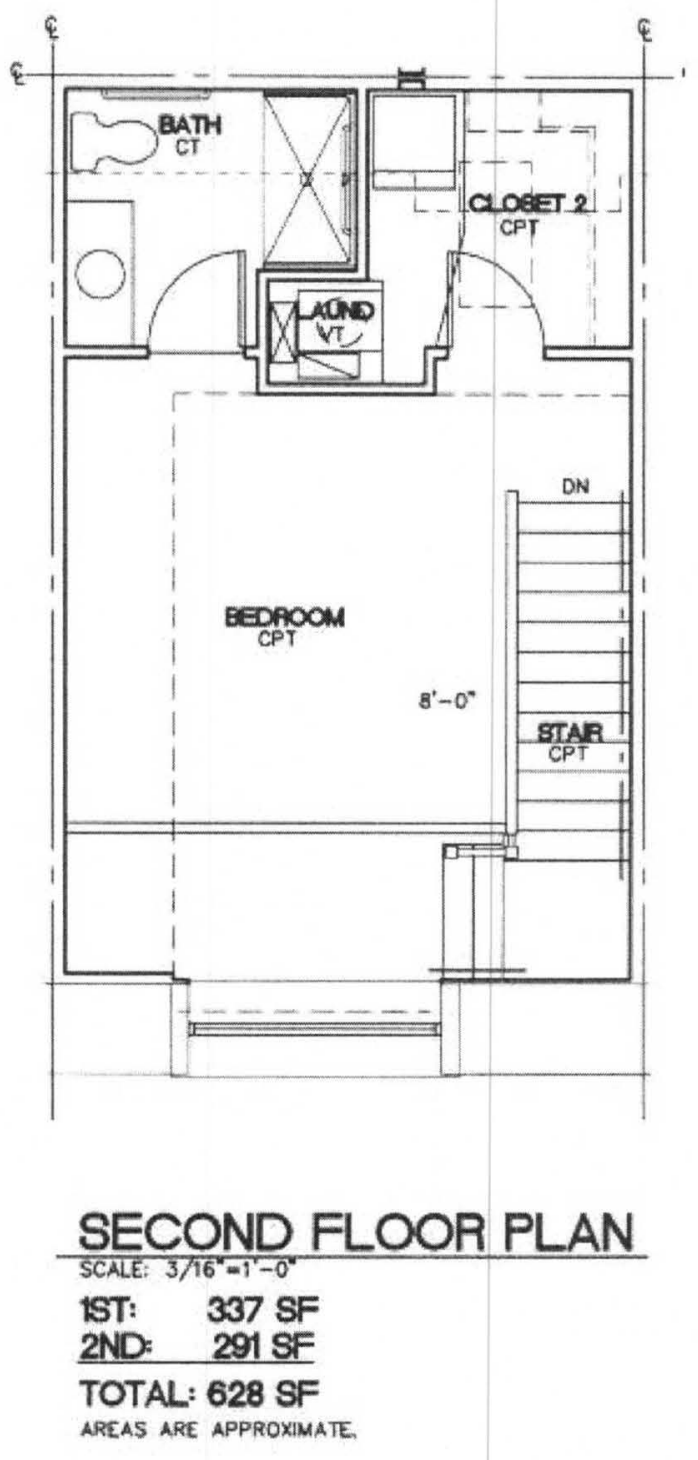

\section{CORPUS CHRISTI APARTMENTS NEWPORT, KY \\ TYPICAL NAVE TOWNHOUSE UNIT UNIT A - SECOND FLOOR}

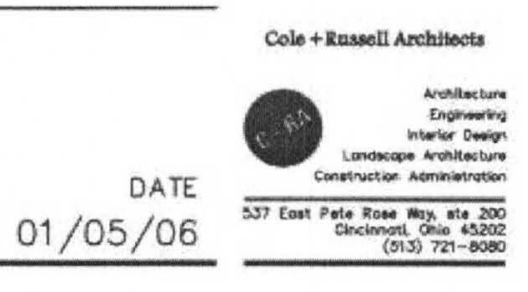

Figure 4.13. Corpus Christi Second Floor Plan. 


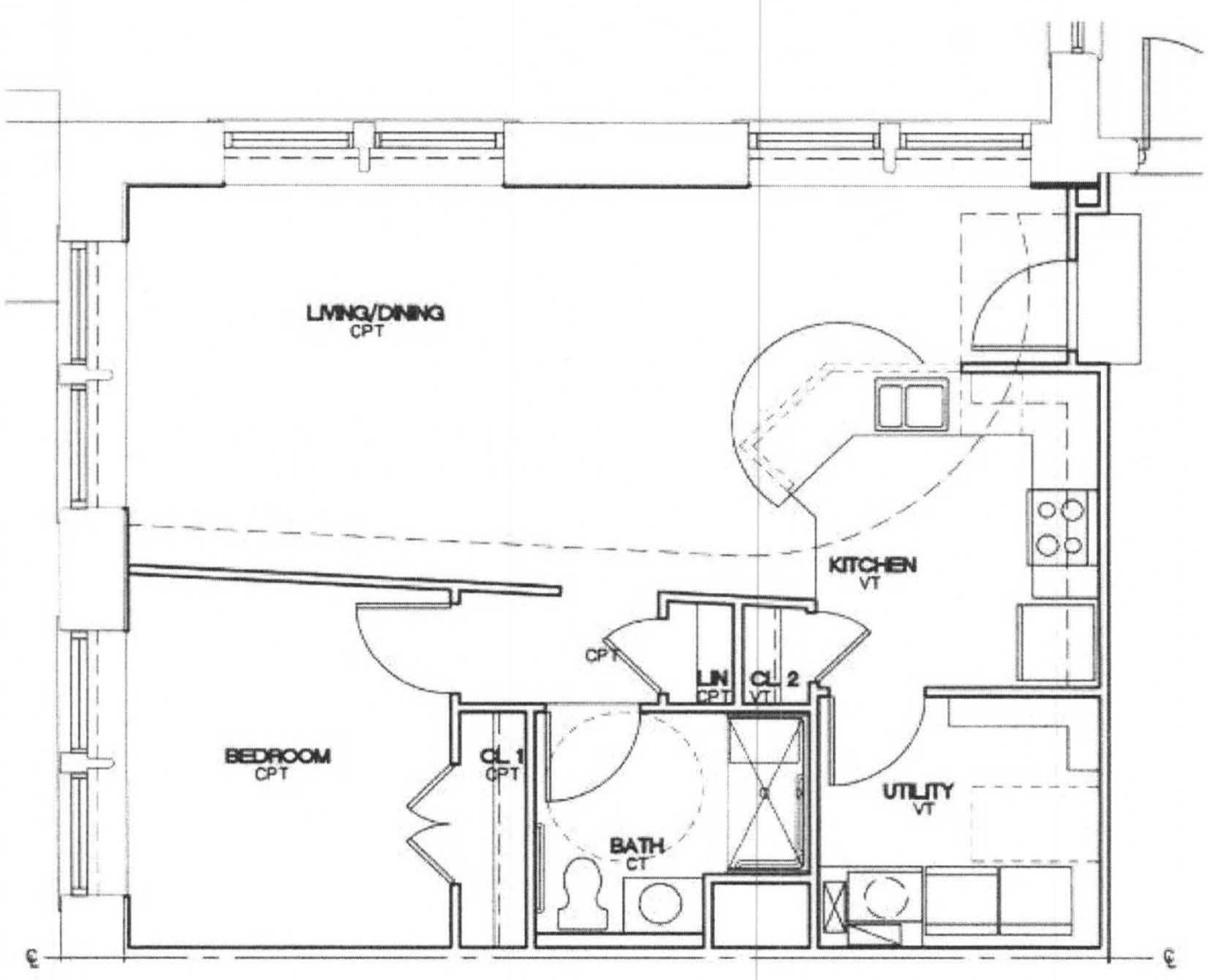

FIRST FLOOR PLAN

AREA: 767 SF

AREA IS APPROXIMATE.

CORPUS CHRISTI APARTMENTS

NEWPORT, KY

TYPICAL THIRD FLOOR CLASSROOM UNIT DATE UNIT F - FLOOR PLAN $01 / 05 / 06$

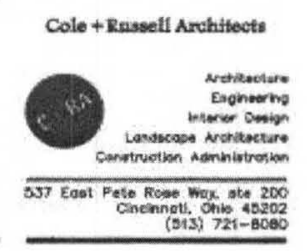

Figure 4.14. Corpus Christi Floor Plan-Third Floor Classroom Unit. 


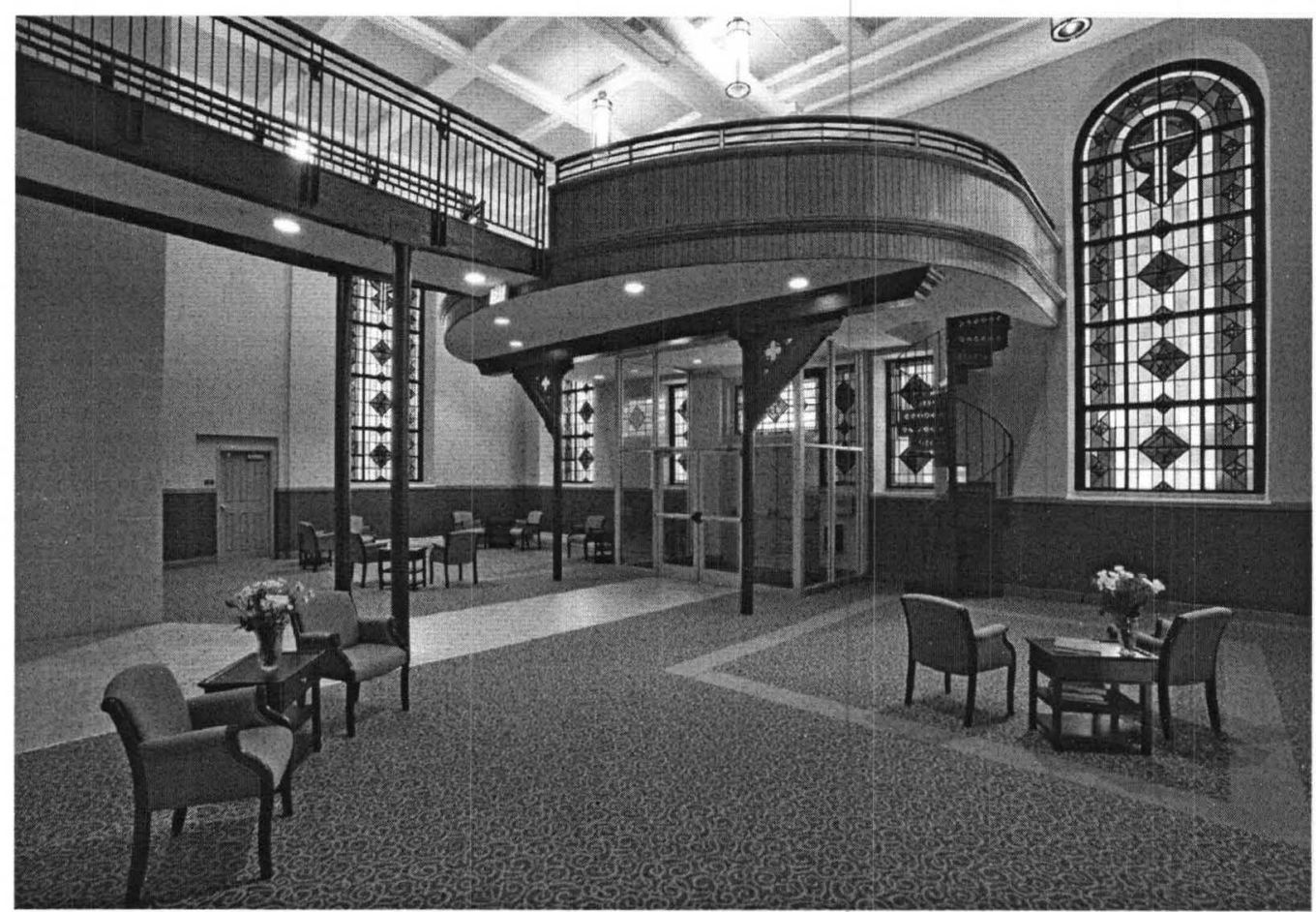

Figure 4.15. Interior of Corpus Christi Foyer.

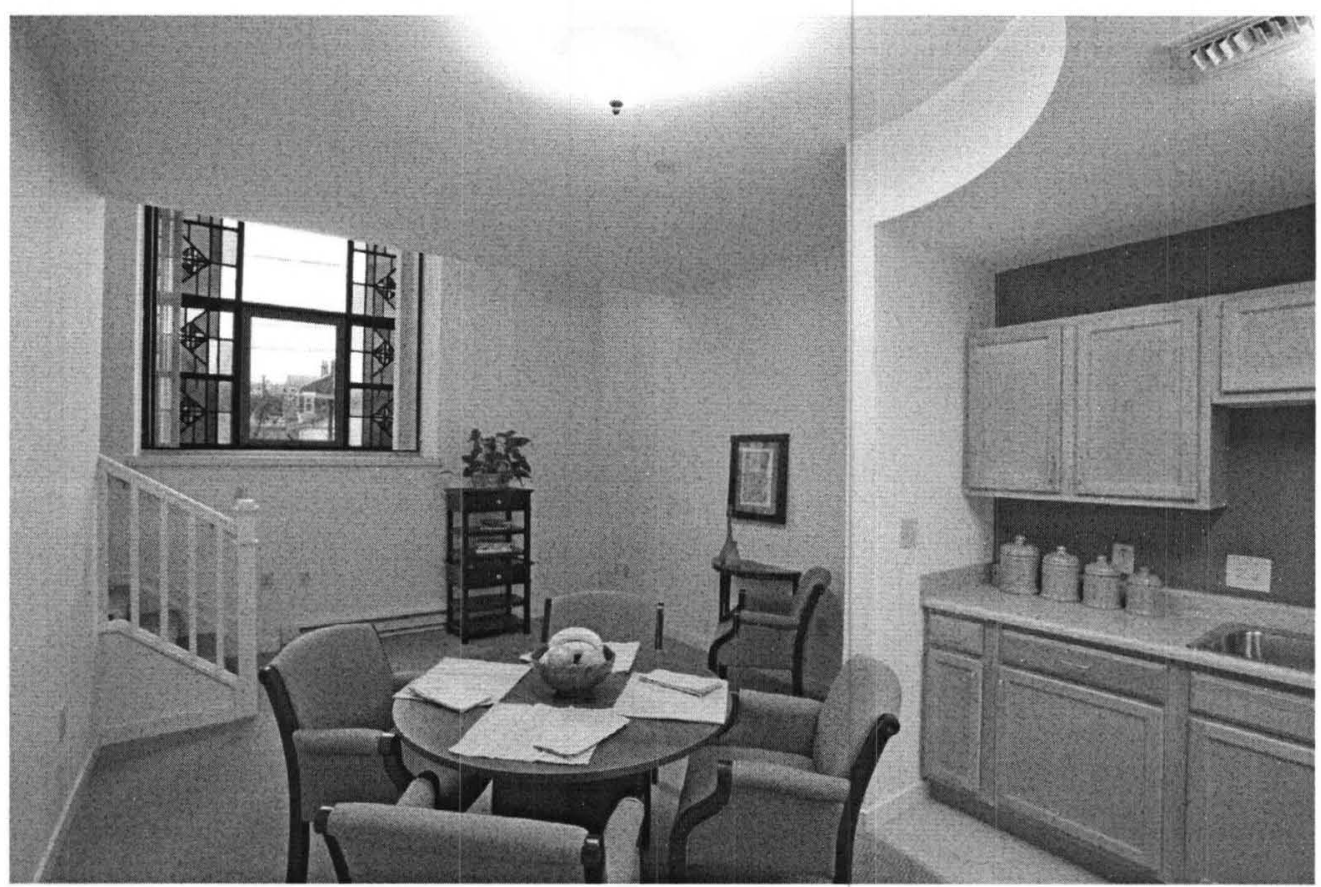

Figure 4.16. Interior of Apartment Kitchen, Corpus Christi Apartments.

(Source: Housing Authority of Newport) 


\section{Liberty Row}

As of 2007, all of the homes in Liberty Row, owned by the Newport New Millennium Housing Corporation have been completed. All 14 homes have been built (13 newly constructed and one rehabilitated). Construction on the Liberty Row Housing project (39 rental units) began in January 2007. HAN has completed seven of the rental units on Roberts Street with full occupancy since going online in September 2007. In

Phase II, 15 of these units are located on West Eighth Street and Liberty Street, and eight homes on Saratoga Street, with the average price rage between $\$ 123,000-130,000$. Unlike the inefficient old public housing built on cinderblocks, where residents of these units paid as much as $\$ 400$ per month on utilities for a 400 square foot unit, many of these units will incorporate energy efficient methods, including Energy Star appliances (Go to Newport, 2008).

HAN acts as the developer and property manager on the Phase II project. Like Corpus Christi, this development is a nine percent LIHTC development, and was completed in August 2008. Also, HAN and Brighton Center received an 811 Grant for the development of housing for persons with disabilities, which they used to develop twelve units. The housing for persons with disabilities is developed for families that have a disabled member, and not solely for those families that have a disabled head of household. 


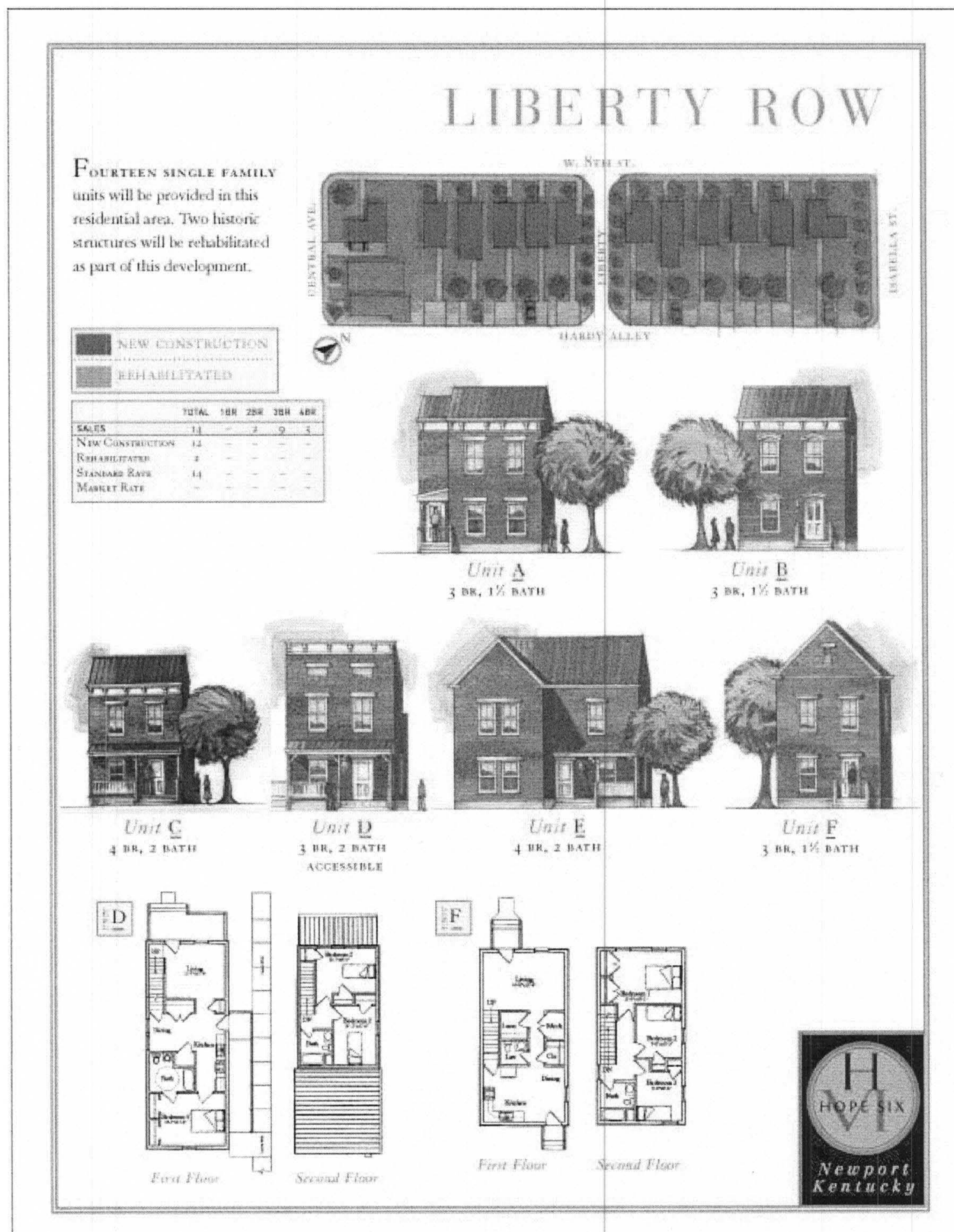

Figure 4.17. Blueprint for Liberty Row. 


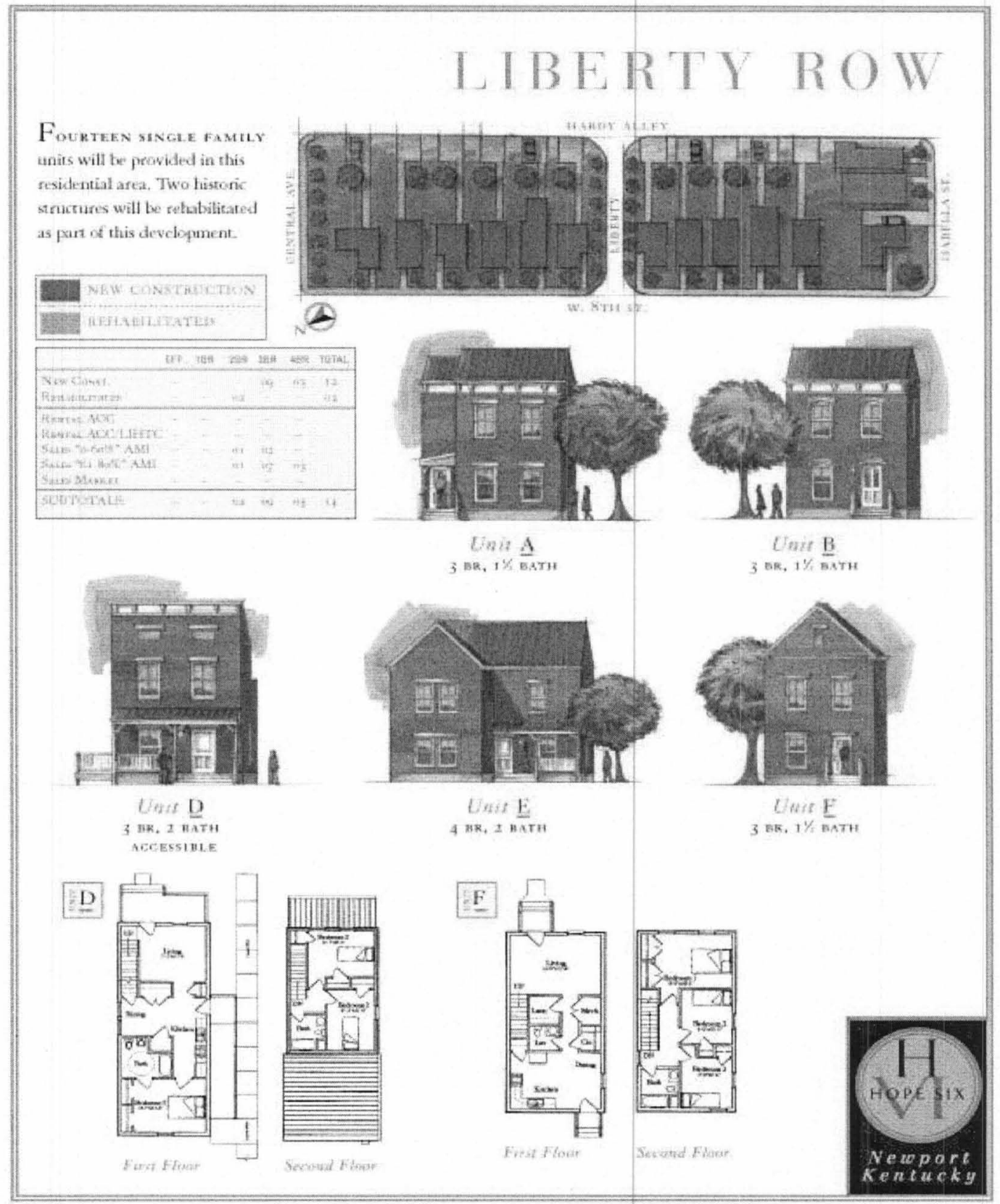

Figure 4.18. Additional blueprint for Liberty Row. 


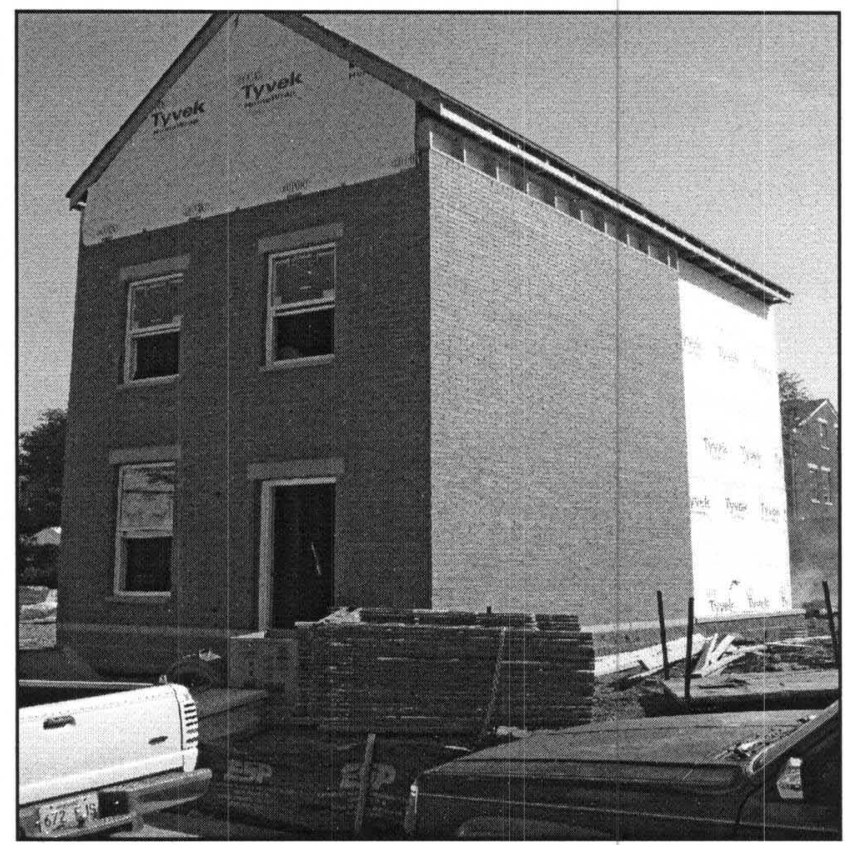

Figure 4.19. Photo of Liberty Housing, Phase II, under construction.

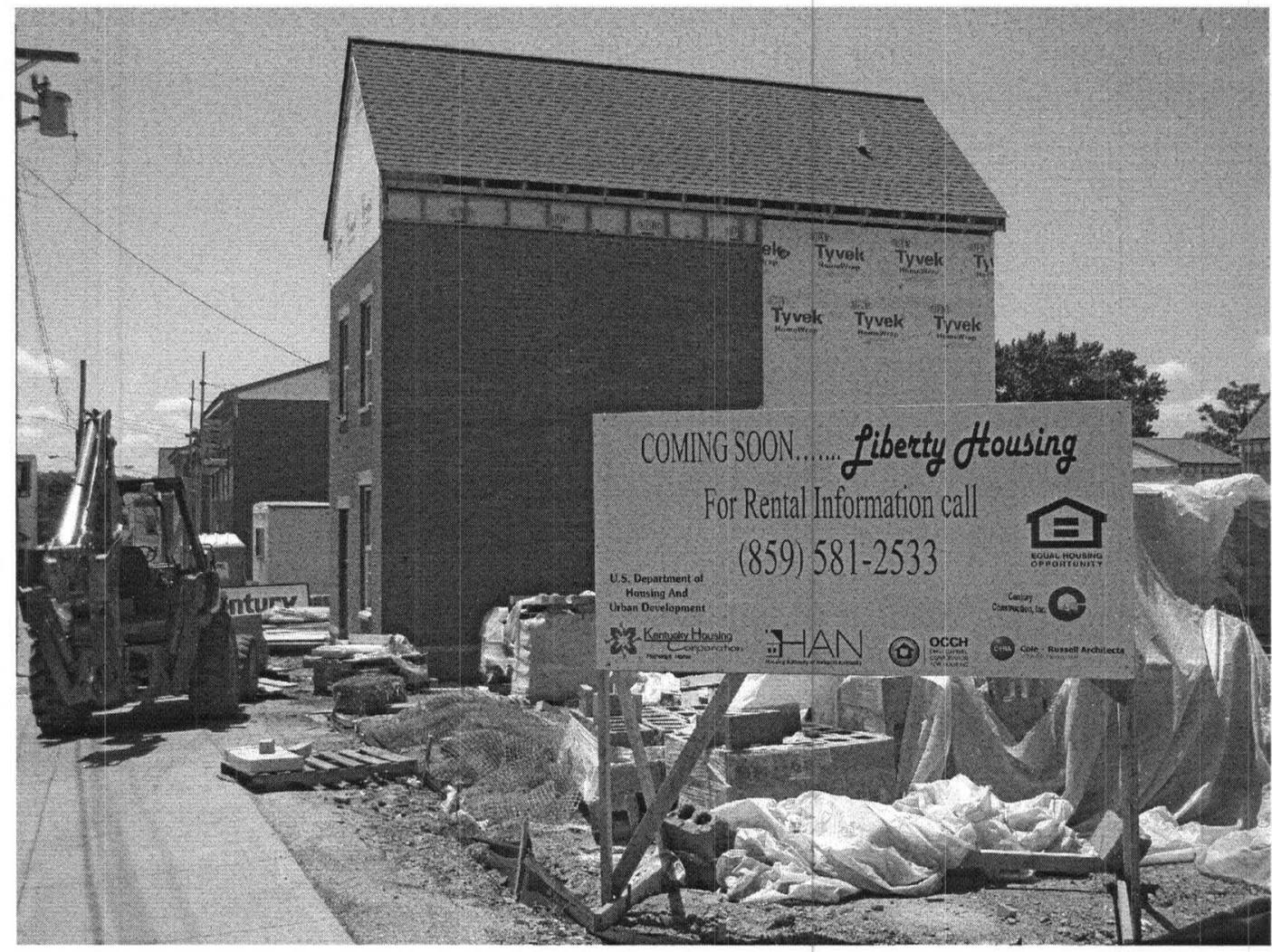

Figure 4.20. Additional photo of Liberty Housing, Phase II, under construction. 


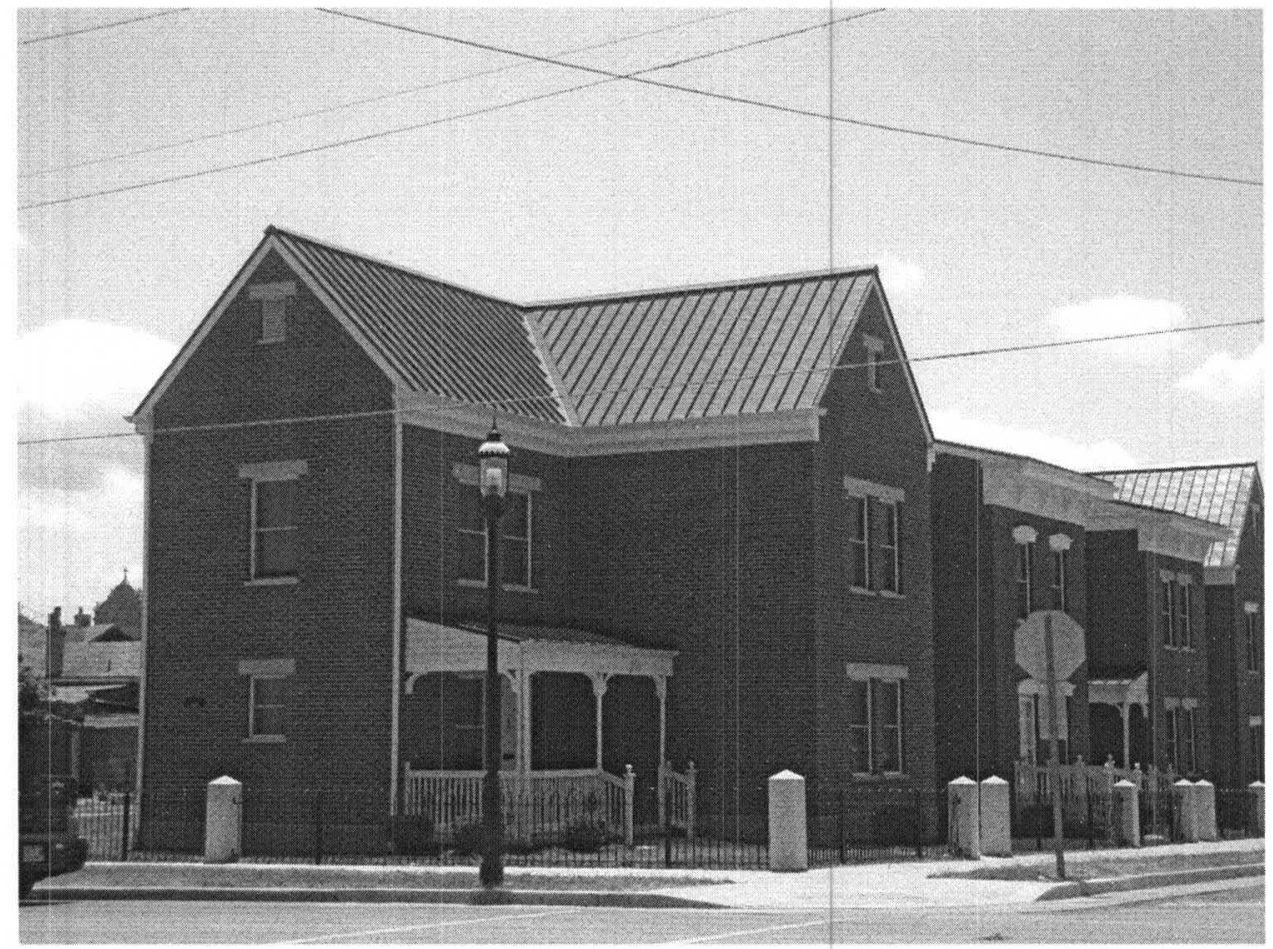

Figure 4.21. Liberty Row.

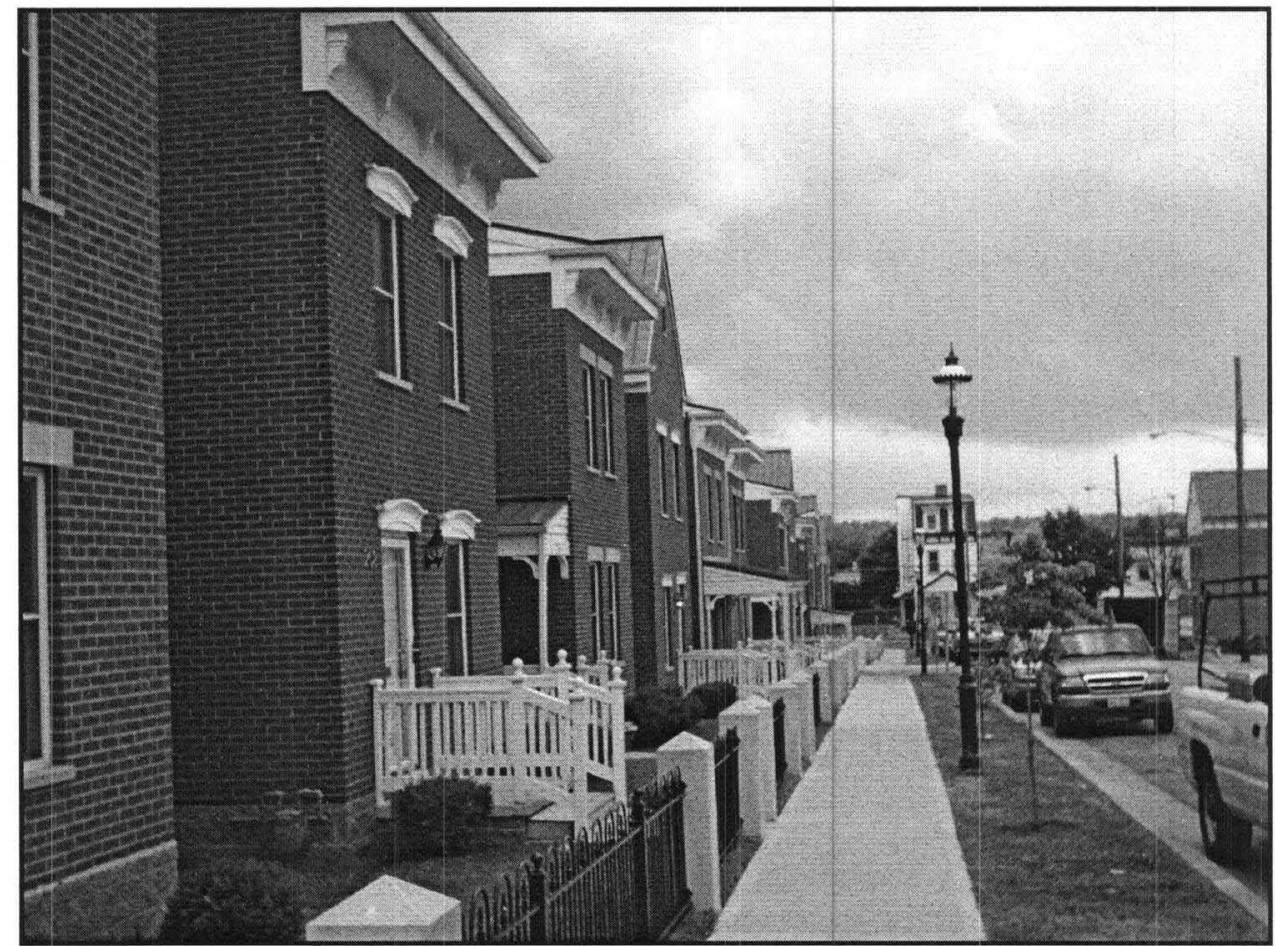

Figure 4.22. Liberty Row. 


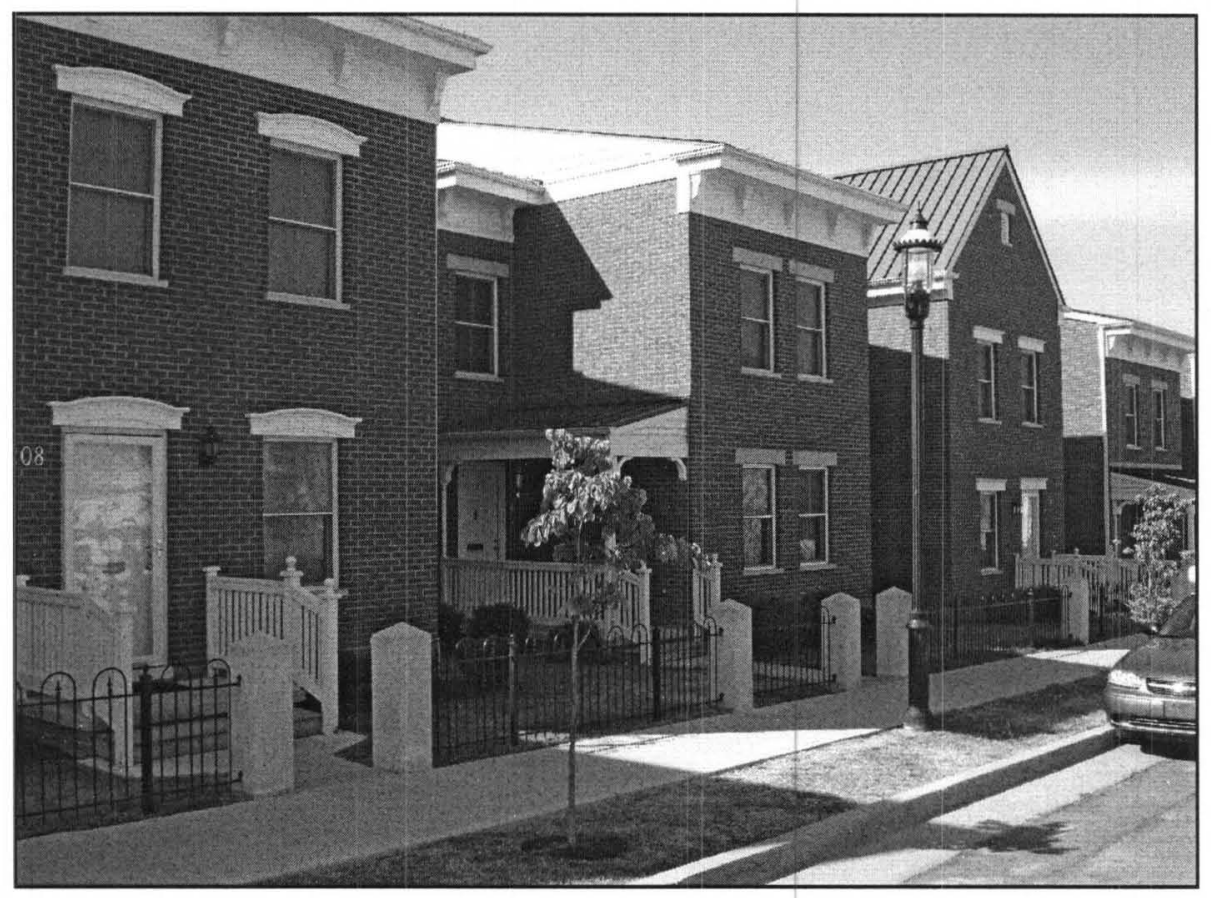

Figure 4.23. Liberty Row.

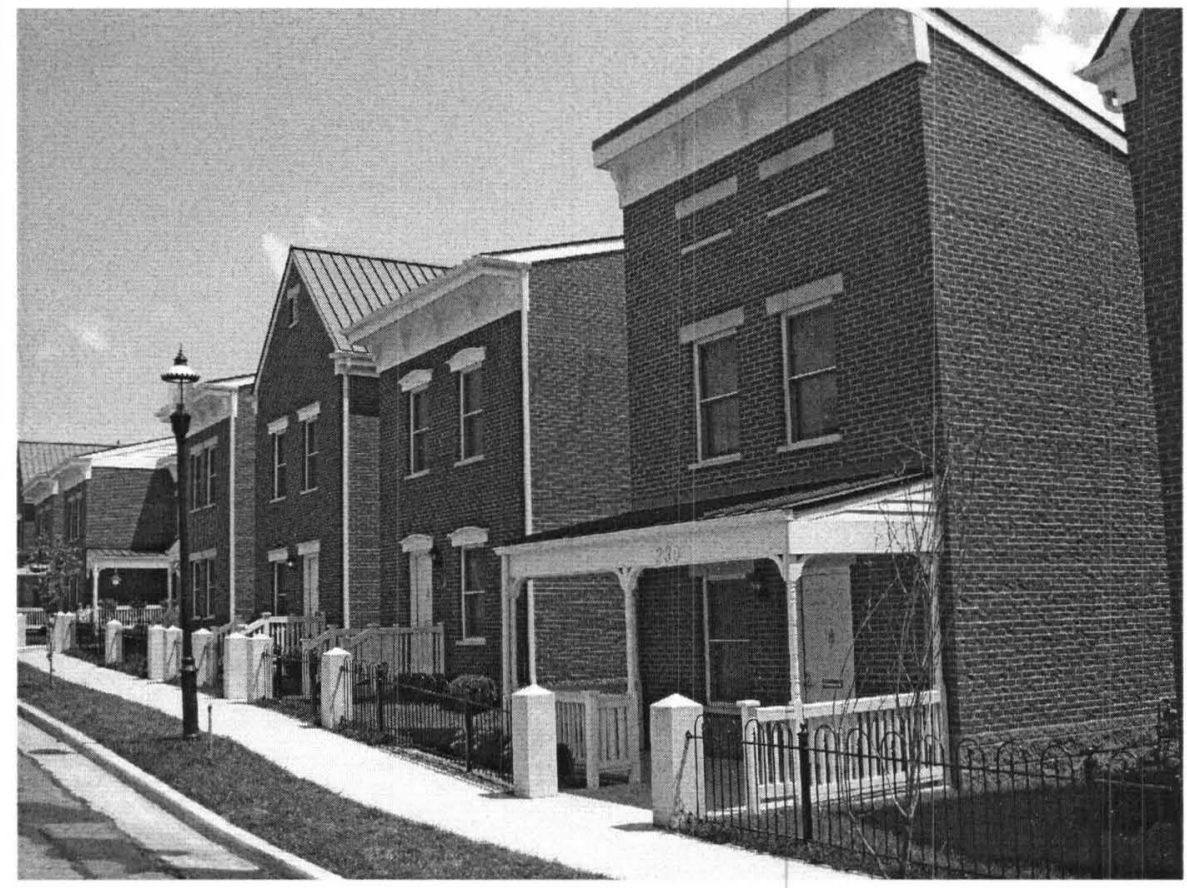

Figure 4.24. Liberty Row. 


\section{Central Housing}

The Housing Authority of Newport has developed an 18-unit, non-tax credit funded scattered-site project called Central Housing. Construction on the twelve historical rehabilitation units began on May 14, 2007, of which six either have been put online, rented, or assigned to prospective tenants, while the six new construction units (the three duplex units) completed the bidding process and began construction in June 2008. Many of the old cottage units served as overflow housing during the early phases of HOPE VI construction. Once again, HAN acted as its own developer and property manager on this project. The new construction units in Central Housing are slated to be completed in May 2009. Darnell added that six row houses have been added to Central Housing above and beyond the commitment HAN made with HUD in the HOPE VI program (George Darnell, personal communication, April 7, 2009).

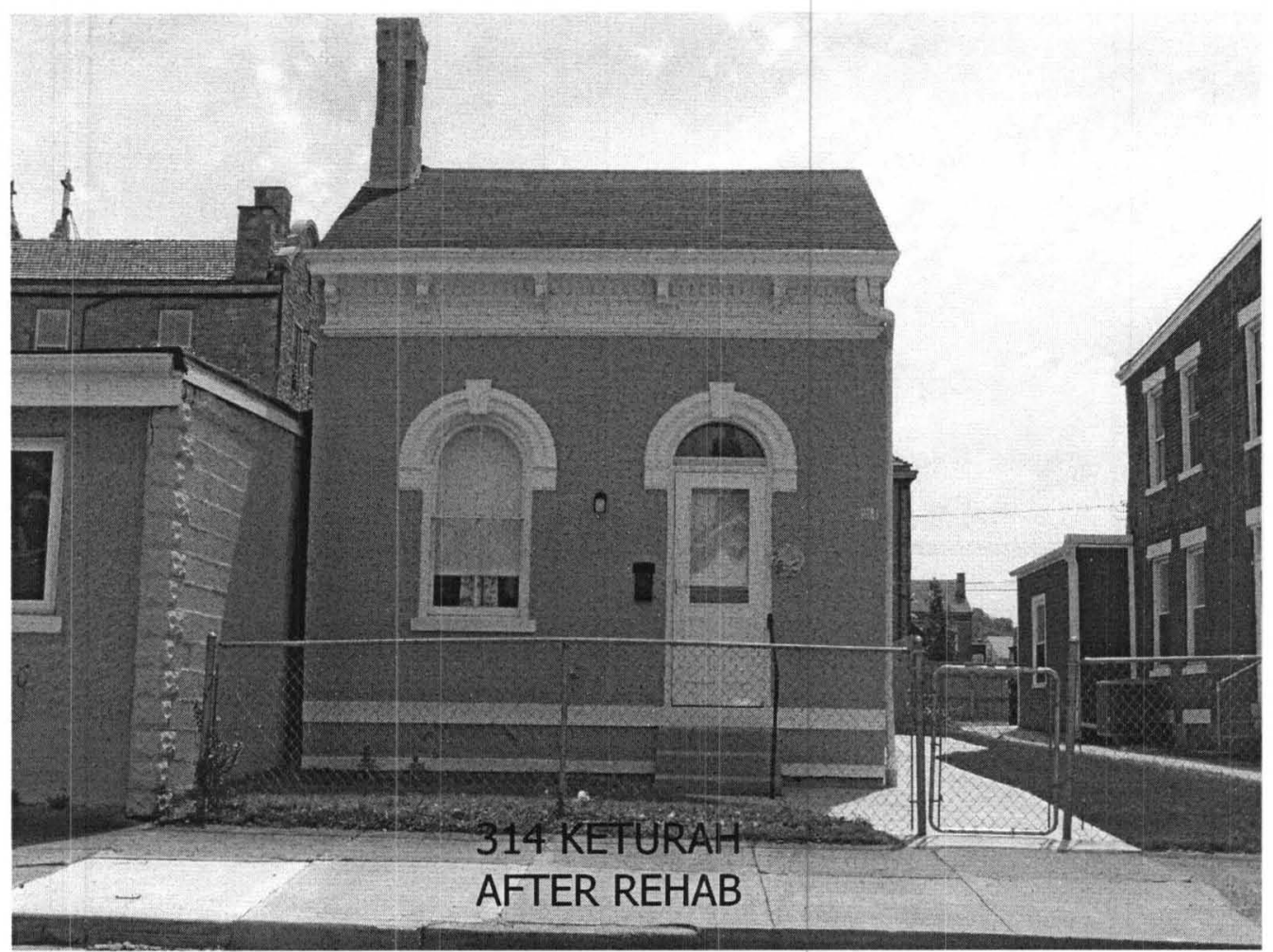

Figure 4.25. HOPE VI Central Housing Rehabilitation, 316 Keturah Street 


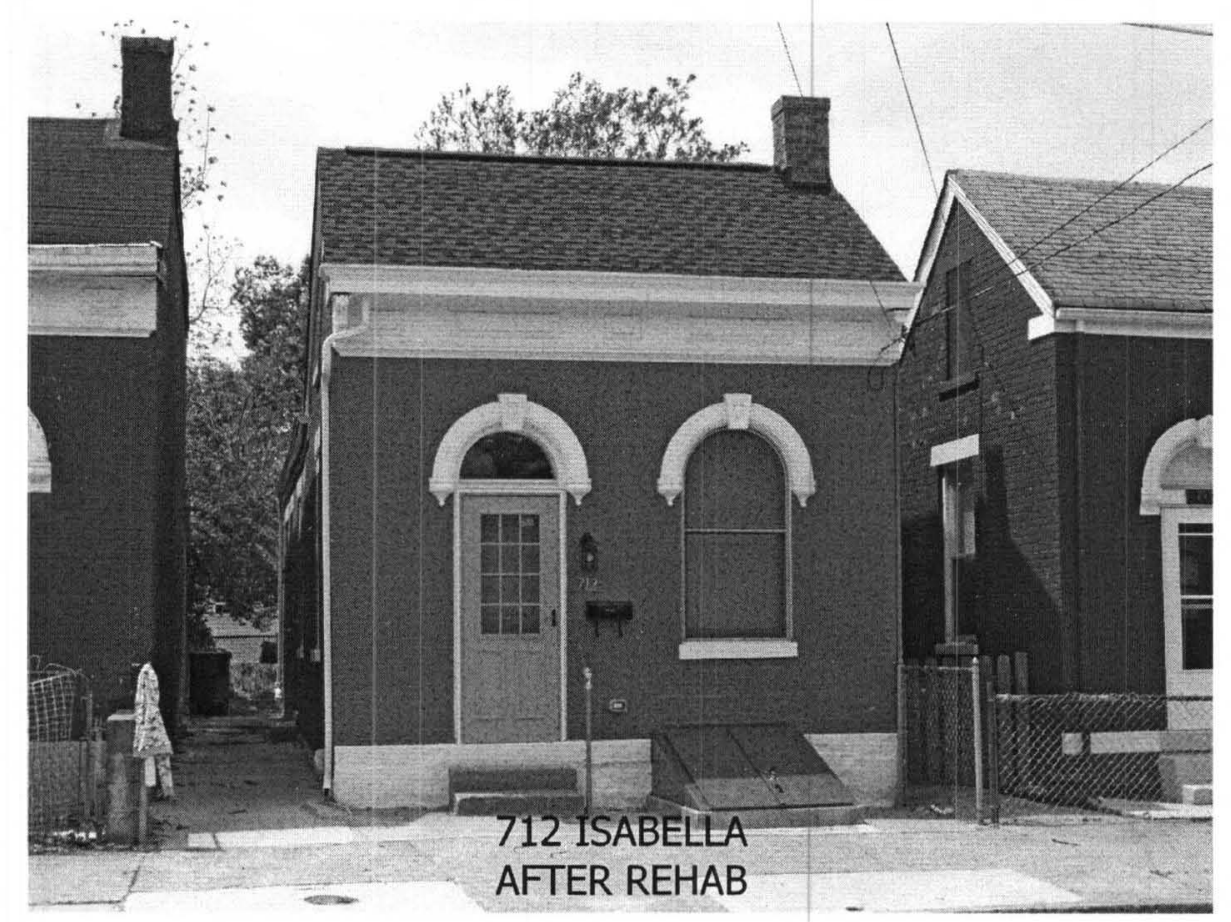

Figure 4.26. 712 Isabella Street after Rehabilitation.

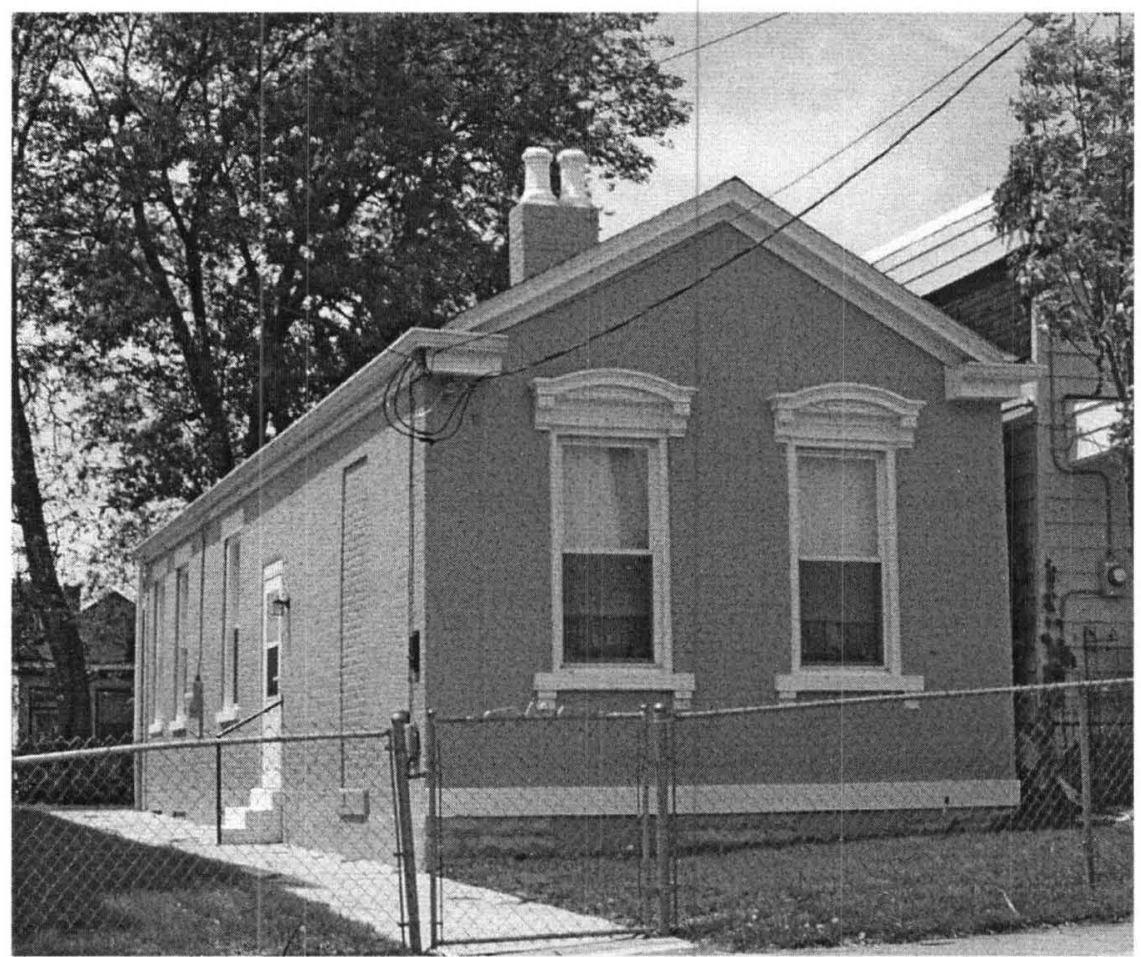

Figure 4.27. 1136 Central Avenue Rehabilitation. 
Many of these rehabbed homes in the HOPE VI program follow principles of green urbanism and sustainability, and provide potential homeowners with reduced energy costs, compared to the old public housing units. These historic homes are in close proximity to many amenities, stores, churches, schools, jobs, and recreation, resulting in no need for automobiles, which is especially attractive during a period of high fuel costs. These homes are designed with high ceilings, transoms, and operable windows, which now provide contemporary residents with an energy conscious alternative to modern heating and cooling systems (Gilderbloom, House, \& Hanka, 2008; Gilderbloom, 2008;

With new advances in energy conservation, preservationists can create new spaces out of unused spaces, such as an attic or basement, into a second office or another rental unit. Energy costs from these conversions are lower through the use of passive solar design, fans, insulation, and proper ventilation (Gilderbloom, House, \& Hanka, 2008). The cost of rehabilitating old buildings is not only more environmentally friendly, but costs less than constructing new buildings with the same amount of space (Gilderbloom, House, \& Hanka, 2008). More importantly, preserving, rehabbing and restoring older historic homes are more affordable for renters and homeowners than building new housing.

\section{City-Wide Project}

As of April 3, 2009, HAN will have sales on the 103-unit, scattered-site, CityWide development and currently acts as developer and property manager of this project. The Housing Authority recently procured Ohio Capital Corporation, a nonprofit affiliate of Ohio's State Financing Agency, as financial advisor. Ohio Capital will assist HAN 
with the development using a four percent LIHTC which also entails a four percent bond financing deal. Construction on this development began in March 2008 and is scheduled to be completed in the summer of 2009 .

HAN received approval from HUD for the HCRH (HOPE VI Constructed or Rehabilitated Homes) Homeownership project; it is a 54-unit project that will construct new and rehabilitate existing homes within the city limits of Newport. Twenty new construction units are located in the Southern Hills area, and 23 new construction and 11 rehabilitated units are located in the City Basin area. These newly constructed and rehabilitated homes will be sold to families that can qualify for the HCRH soft second mortgage loan, earn up to 80 percent of the average median income (AMI), and satisfy all other criteria per HCRH program guidelines. Families that are recipients of Housing Choice Voucher (Section 8) certificates also are eligible to purchase one of these homes, according to George Darnell, HOPE VI Coordinator for the Housing Authority of Newport (Housing Authority of Newport, 2007).

As of April 3, 2009, 14 homes have been built and are owned and occupied at Liberty Row I site; 15 homes at the Liberty Housing site were completed in the summer of 2008, with all of these units completed and rented. The eight units at the Saratoga Street site were completed in October 2008 and the 11 rehabilitation units at the Hamlet Street site begun in September 2008 will be completed by July 2009. This brings the total to $68 \mathrm{HRCH}$ homeownership units in addition to the $65 \mathrm{CIPP}$ homes. 


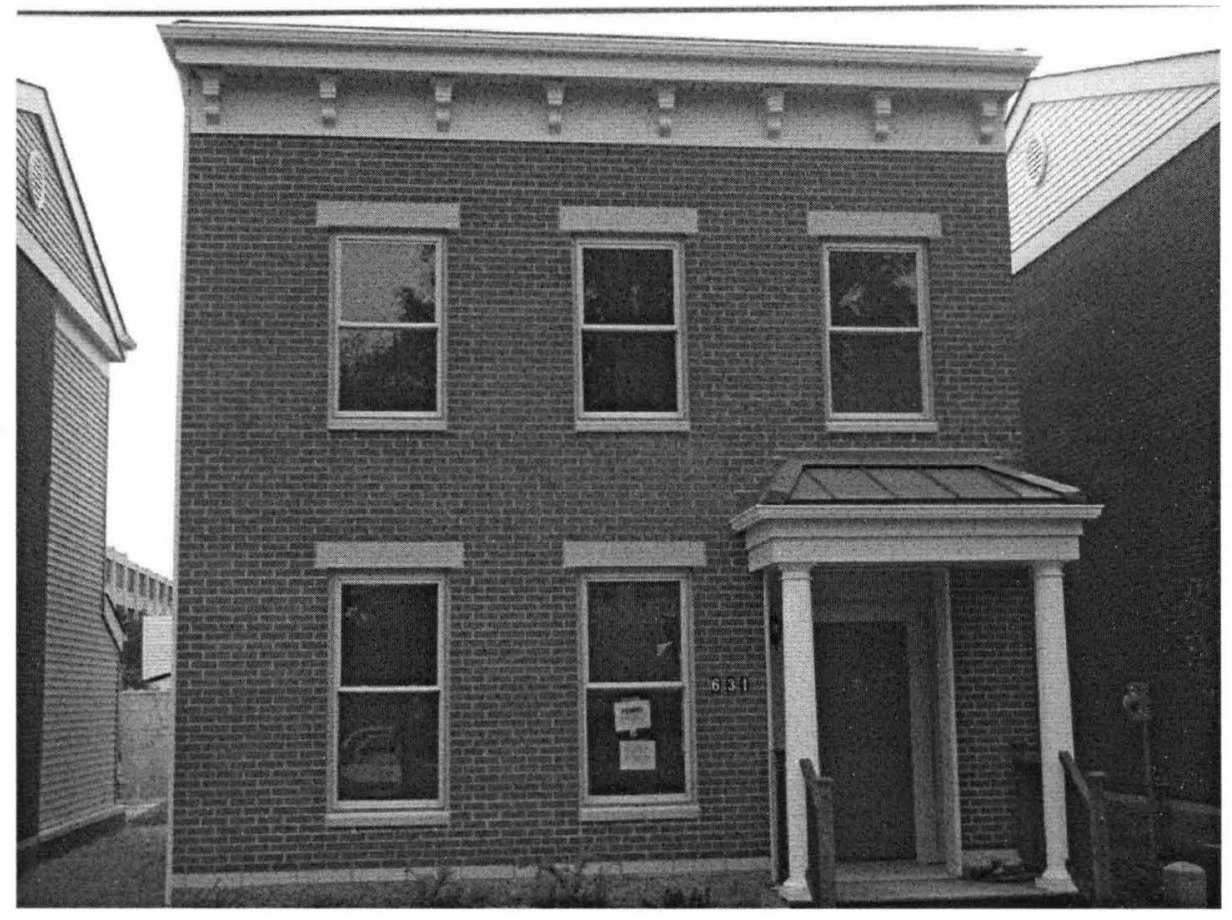

Figures 4.28 HOPE VI Homes on Saratoga Street.

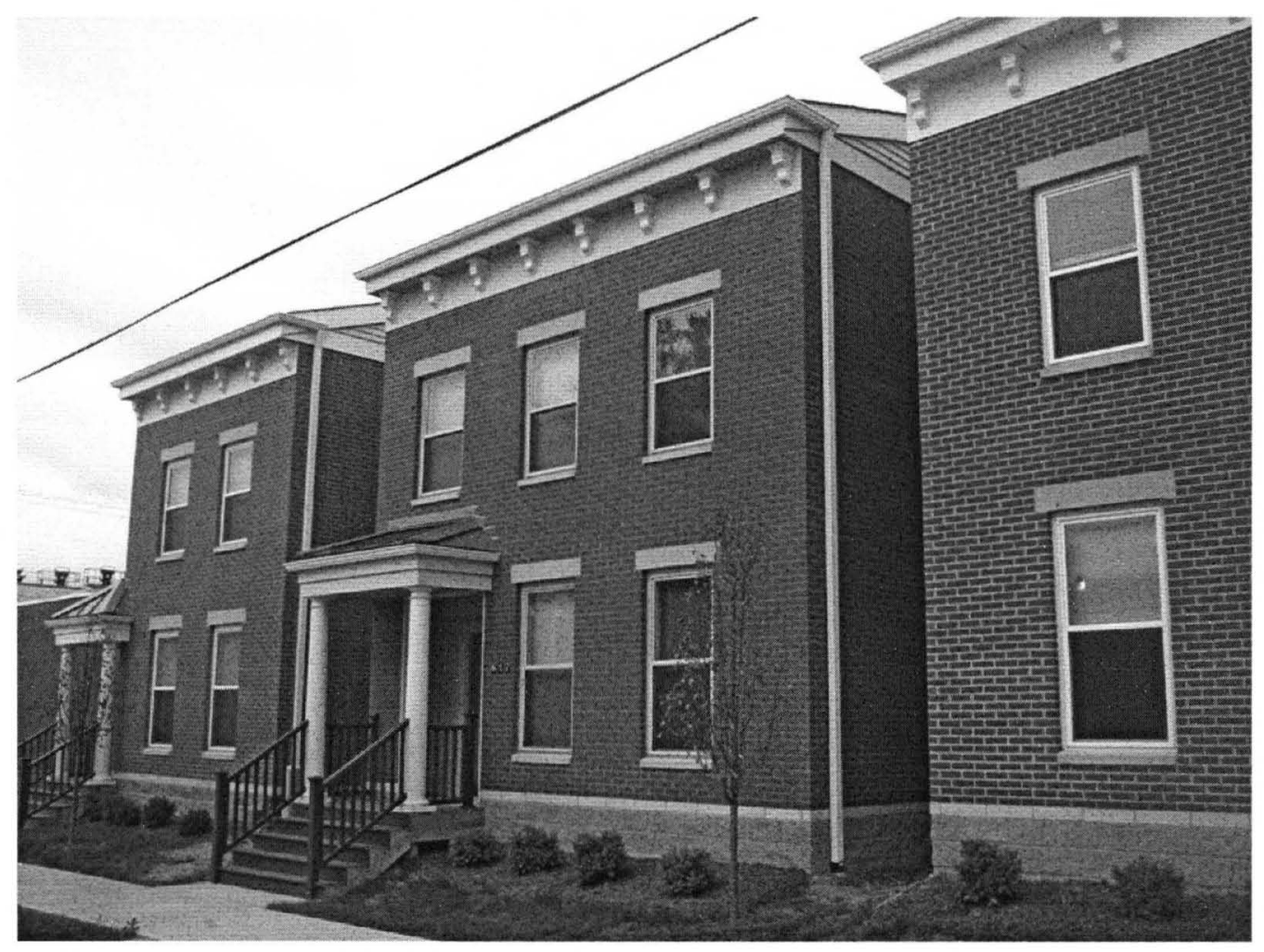

Figure 4.29. HOPE VI Homes on Saratoga Street. 


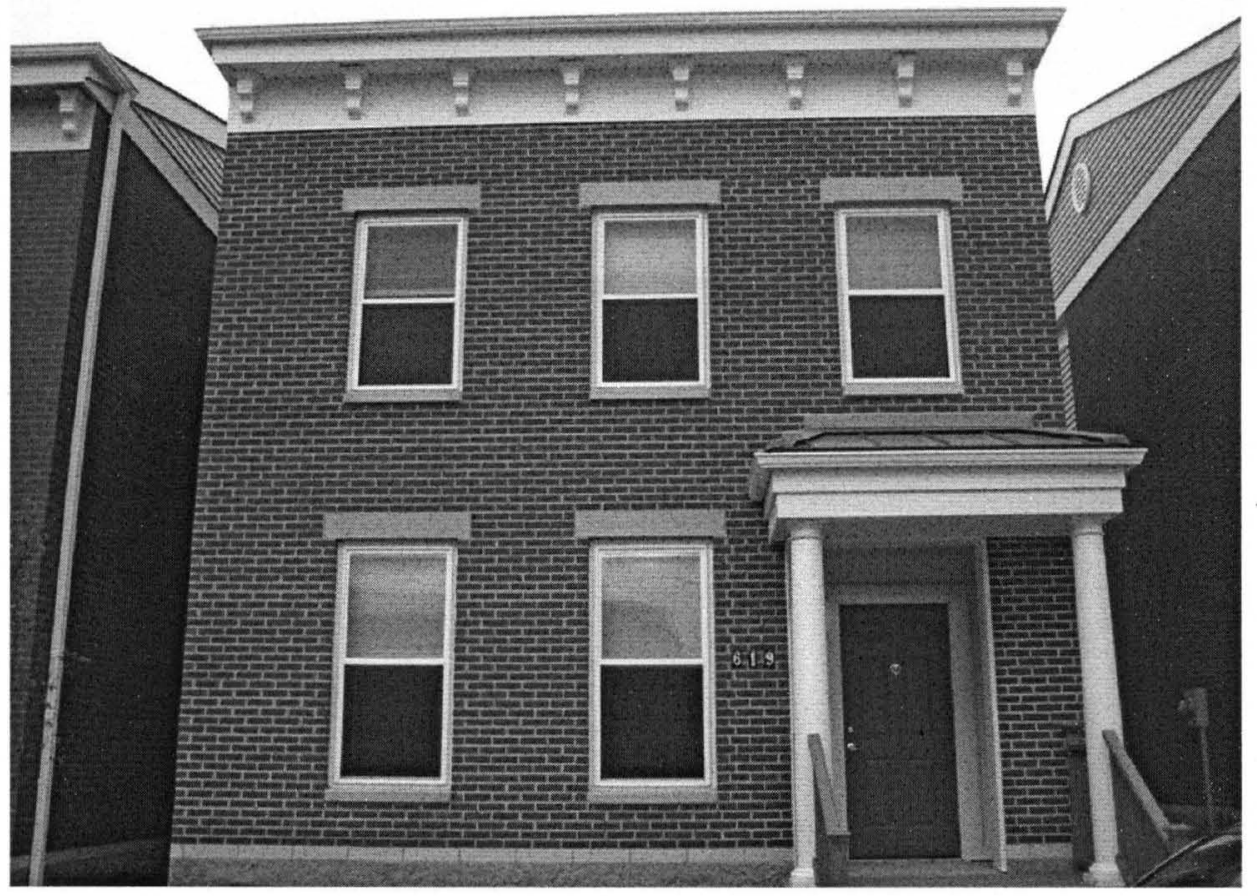

Figure 4.30. 619 Saratoga Street.

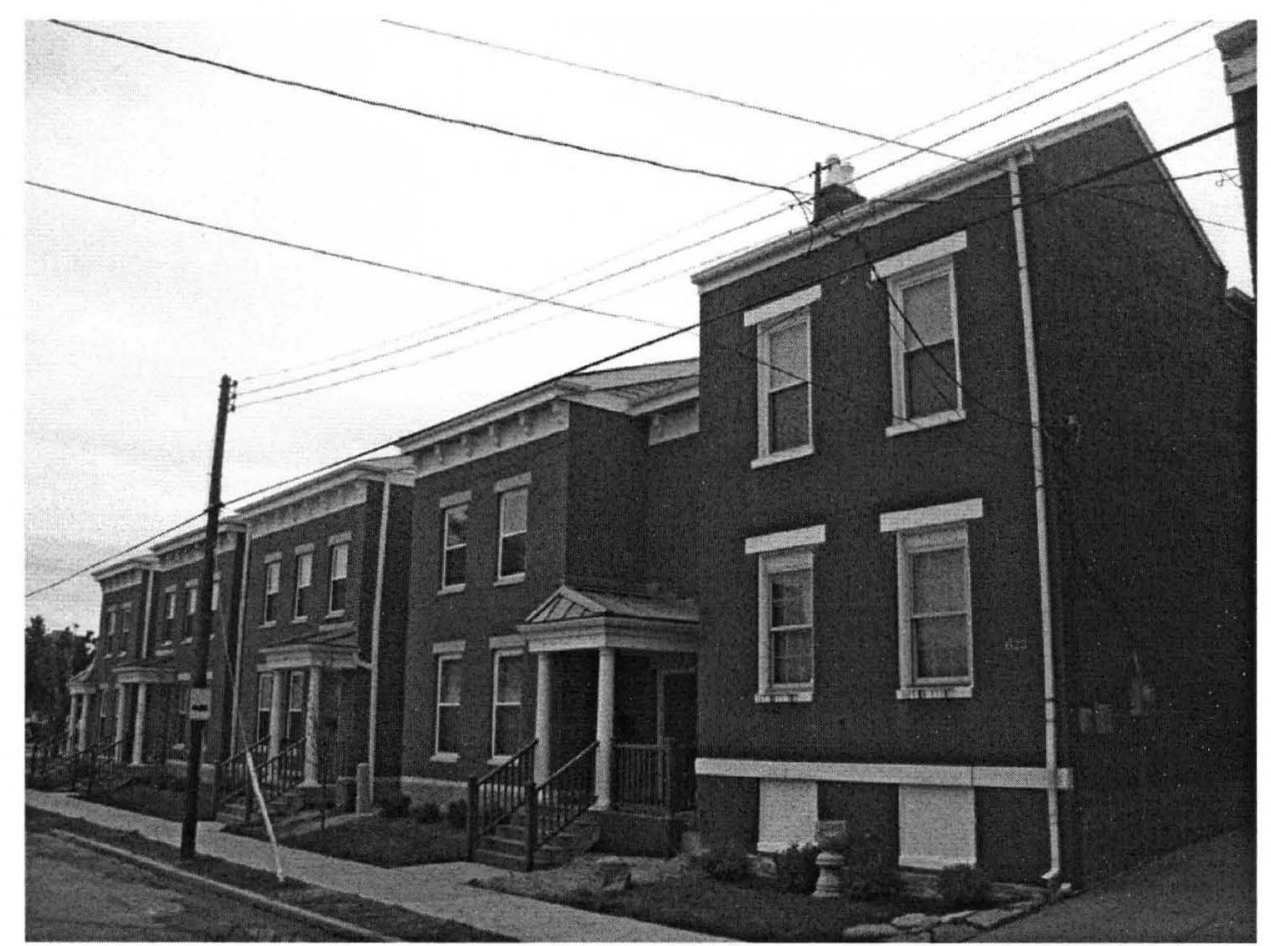

Figure 4.31. Saratoga Street HOPE VI Homes. 
According to Darnell, buyers of the HCRH homes are eligible for either the HCRH soft second mortgage financing (up to $\$ 35,000$ ) or a Community Development Block Grant (CDBG) grant soft second mortgage financing at $\$ 40,000$. The HCRH/CDBG subsidy is accompanied with a promissory note, where the homebuyers pay no periodic payment on current principal or interest on the soft second mortgage loan as long as they own their home for a minimum of five years (HCRH) or eight years (CDBG), and after that five or eight years, the loan will be forgiven at a rate of 20 percent per year (HCRH) or 12.5 percent per year (CDBG). The 68 HCRH homeownership homes all will be completed by June 30, 2009.

In addition to HCRH, the Community Investment Partnership Program (CIPP), HAN's other soft-second mortgage program, assists qualified low and moderate-income homebuyers, which includes the general public, HAN residents, and housing voucher program participants per the CIPP guidelines (Housing Authority of Newport, 2007). To date, HAN has provided forgivable loans to 65 low and moderate-income homebuyers that have purchased homes throughout the city of Newport. The CIPP program began with over $\$ 1.6$ million. Now, the program is terminated, having closed its $65^{\text {th }}$ and final loan in November 2007.

\section{Conclusion}

Since the development agreement was signed on September 30, 2002, and the resubmitted schedule was approved by HUD on August 1, 2003, HAN has completed 235 of its 325 units agreed upon by June 30,2009 . According to the agreement, all of the $\$ 28$ million of HOPE VI Grant must be committed or used by the end of December 2008 and 
completed by June 30,2009 . Of the 192 rental units, nearly all are under construction; 89 units have been completed. Of the homeownership units, 37 units are completed, including 8 units on Saratoga Street and another 11 at Saratoga/Roberts are near completion. According to Linda Fields, Deputy Director of HAN, the homeownership units enjoyed a short turnaround time, and are leasing anywhere from a few days to a few weeks after receiving the certificates of occupancy (personal communication, April 8, 2009).

The slow progress by the Housing Authority of Newport to acquire property, construct or rehabilitate the homes, and need to extend the deadline to the end of June 2009 has been a result of the regulations, procedures, and approval process through Newport's Historic Preservation Office. The difference between the Historic Preservation Office's timetable of negotiating the purchase of property and the approval of the designs, and HAN's timetable toward completing the early phases of the project delayed the rehabilitation of existing housing and the construction of new housing units.

The Newport HOPE VI Project was approved by HUD in 2000, with a goal set by HAN to complete the project by June 30,2009 , and it is on schedule to meet this deadline. However, there have been several obstacles to HAN's project that were not faced by other HOPE VI projects. Since units were not being built on the original public housing site, HAN planned to acquire properties scattered throughout Newport. This allows tenants and buyers to live in various neighborhoods throughout the city of Newport. The acquisition of property was a four year process which included demolition, environmental abatement, site preparation, and in some cases relocation of sellers and tenants. Many of these neighborhoods were located in areas that were labeled 
to be historically significant by the Kentucky State Historic Preservation Office. As a result, HAN spent significant time in negotiating purchasing property for preservation and for reaching agreements for design approval. The remaining properties were demolished for construction.

In 2006, the Housing Authority of Newport decided to become the developer of the projects. This change allowed HAN to reduce the cost of construction and related costs. It also allowed for reducing costs that would otherwise be paid to an outside developer. As a result, there was a significant increase in construction time for current projects, with the City-Wide Project prepared to finish on or before June 30, 2009.

From the beginning of the decade, where the city of Newport pursued and applied for the HOPE VI grant to the demolition of the old public housing to the constructing of 201 new units, to the economic development and business incubation along the riverfront and in the central business district along Monmouth Street, the city of Newport has seen a great return on the investment from the federal government.

While this chapter examines the history of Newport and Newport's housing, past and present, and provides an overview of the physical redevelopment of the new HOPE VI housing, the next chapter examines the social services provided by the Community and Support Services (CSS), the case management program of HOPE VI. The next chapter will analyze of the survey instrument given to CSS participants who enrolled and participated in the program measuring residential satisfaction, quality of life, and selfsufficiency. 


\section{CHAPTER V}

\section{ANALYSIS OF COMMUNITY SUPPORTIVE SERVICES (CSS) PROGRAMS AND RESIDENTIAL SATISFACTION SURVEY}

The last chapter provided a historical overview of housing in Newport, Kentucky from past to present. This chapter examines the role of HOPE VI's case management program in the overall residential satisfaction and quality of life of the residents who participated.

In 2001, the Housing Authority of Newport (HAN) contracted Brighton Center, Inc. for supplemental social services during the federal HOPE VI project. HAN granted $\$ 2$ million of the total $\$ 28.4$ million HOPE VI budget for Brighton Center's operation of the Community and Support Services (CSS) program from 2000 through June 30, 2007.

CSS, the case-management program for all HOPE VI programs, came out of the Personal Responsibility and Work Opportunity Reconciliation Act of 1996. This legislation helped residents get jobs and stay employed by using training and services as a means to greater self-sufficiency. CSS also provides post-employment training services, which assists individuals in obtaining better jobs (Kingsley \& Covington, 2000, 4).

In the initial stages of the contract, Brighton Center conducted an extensive 18page, person-to-person survey on the existing situation of residents living in Housing 
Authority of Newport (HAN) public housing. The survey intended to identify each household's strengths and weaknesses in order to tailor programs to fit their unique needs over the course of the five-year program. Since Brighton Center had not exhausted the funds allotted it in the budget by the 2005 scheduled conclusion of CSS, the contract was extended until June 30, 2007.

As the CSS Program concluded, 99 previously case-managed individuals and families were transitioned into other programs to ensure service continuity. The demographics are as follows: 23 families are inactive; 76 families are active and have 135 family members. Of these 135 members, 78 are over 18 (65 adults, eight seniors, and five young adults), 57 are under the age of 18 (seven high school students, eight middle school students, 32 are grade school students, and ten children are ages zero to five).

The CSS program in Newport is a public/private partnership between the Housing Authority of Newport and Brighton Center. Brighton Center is within walking distance to most of the new HOPE VI sites as well as to affordably-priced residential neighborhoods and the existing Housing Authority in Newport public housing neighborhoods (south of the old public housing). Brighton Center provides a one-stop shop for families in need of assistance and does this in a community-center atmosphere. Brighton Center offers a comprehensive continuum of programs and services that are available to CSS families, such as credit counseling, employment training, youth activities, GED classes, home and car ownership, budgeting, family health services, and health and childcare services.

At the time of the assessment in November 2000, 22 of the 179 CSS participants (12 percent) were employed (three part-time and 19 full-time). Figure 5.1 on the next page tracks the percentage of CSS participants that are employed. The number and 
percentage of CSS participants that are employable, or expected to be in the labor market, are all adults between the ages of 18 and 61 years of age who do not receive either Supplemental Security Income (SI) or Social Security Disability Insurance (SSDI) (Levy and Woolley, 2007).

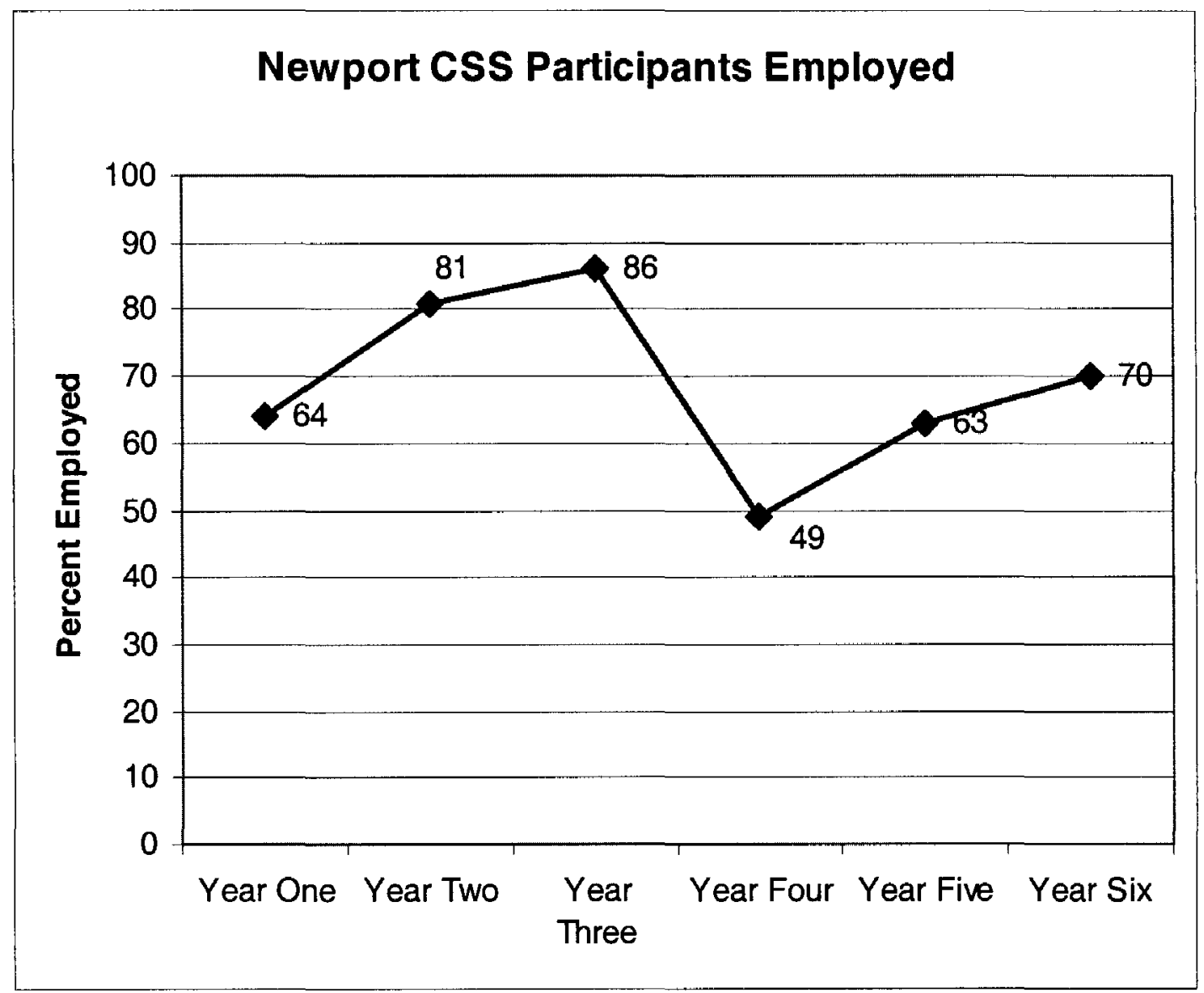

Figure 5.1. Newport CSS participants employed. 
In the first year (July 1, 2001-June 30, 2002) there were 122 employable residents and 78 of those were employed, resulting in a 64 percent employment rate. In the second year (July 1, 2002-June 30, 2003) there were 95 employable residents and 77 were employed, or 81 percent. In the third year (July 1, 2003-June 30, 2004), 89 residents were employable and 77 were employed, resulting in 86 percent. In the fourth year (July 1 , 2004-June 30,2005 ) there were 74 employable residents and 49 percent, or 36 residents were employed. In the fifth year (July 1, 2005-June 30, 2006) there were 72 employable residents and 46 residents, or 63 percent, were employed. In the sixth year (July 1, 2006June 30,2007$)$ there were 66 employable residents and 70 percent ( 46 residents) were employed.

According to Denise Govan, Family Center Director for Brighton Center, one of the biggest factors for the changes in employable residents was the high turnover rate with residents. The drop in the percentage of employable residents between years four and five was the result of employable families being evicted. When the families are evicted, they are not counted and are pulled out of the equation. Despite the fluctuations, 46 of the 66 employable residents that remained in the CSS program, or 70 percent, were employed at the end of the sixth year, compared to 22 of the 179 employable residents, or roughly 12 percent, at the time of the initial assessment in November 2000 (Gilderbloom, Hanka, and Lasley, 2008).

All HOPE VI participants were notified about credit counseling opportunities provided by Brighton Center. When participants showed interest in the credit counseling class, they were screened by a motivational interview which assesses individual 
intentions. Pretests and posttests were given to individuals who participated in the classes in order to track general knowledge attainment, and the overall effectiveness of the content of the credit counseling class.

The two top credit issues among participants are home ownership and car ownership. Another common credit counseling issue is high levels of debt, which can be difficult to address. Of all the program participants, 62 individuals have had their credit report pulled due to the inability to manage their credit, 12 continue the process of resolving credit issues, and 38 families have fully resolved their serious credit issues.

Of the original 179 households, ten households have purchased homes, 26 have moved to the South-site of the Housing Authority; nine used their Section 8 voucher in Newport and 14 households used their vouchers elsewhere (three households moved to Cincinnati; one to Ohio; two to Wilder; one in Kenton County; five in Covington, of which two are Brighton Property tenants; one in Hebron and one in Highland Heights). Also, two households are in senior buildings in Newport; 20 have an unknown address, five have signed out of the program, 51 have been evicted, three have died, and 37 have relocated on their own. Also, twenty-eight individuals have completed "Yes You Can" classes, a first step toward homeownership, while forty-one individuals are working on financial literacy in the Money Matters classes offered through credit counseling services. Also, nine residents have completed Brighton Center's Center for Employment Training (CET). Nine are working full-time and seven are working full-time with benefits.

Out of the residents who are pursuing postsecondary education, two residents have graduated from a postsecondary college (Southwestern and Cincinnati State in Cincinnati), and one has completed the Job Corps program. One resident is currently 
attending Northern Kentucky University and is on the Dean's List. Three attended Gateway Technical and Community College, and one attended Alice Lloyd College. The HOPE VI Community Learning Center and the Newport Adult Learning Center offer adult education classes that have been attended by 46 residents. The Test of Adult Basic Education (TABE) has been taken by 56 residents, of which 27 have increased TABE scores since the program's inception. Thirteen out of the 41 who need their GED have received it since the program's inception, and six are working toward their GED; 30 residents have taken and passed the practice GED test.

Brighton Center has offered youth programs as alternative extracurricular activities. These programs have provided supplemental skills to the targeted youth. Girl Scout Troop \#702 was formed in June 2003 and had the regular participation of 21 girls in the program. Also, thirty-four girls attended a Girl Scout Day Camp in the summer of 2006. Eight youth have completed the Youth Career Paths Program, where each participant has gained valuable skills that will assist them in the job market. A total of 12 children have graduated from the Youth Leadership Development Program, where they have gained skills in community service, positive self-image and positive peer interaction. Right now, two youth are enrolled and nearing graduation.

Brighton Center contracted Summit Behavioral Health to serve 25 residents on site to counsel individuals around a wide range of issues. Twenty-nine individuals received some type of counseling/therapy service. Brighton Center partnered with a local dentist to provide services for four CSS participants. These residents had major dental repair including complete dental extractions and replacement dentures. Lack of dental care plagues a large percentage of the individuals and families in the low-income 
community. For these particular residents, their new smiles have increased their confidence to move forward towards their self sufficiency goals. Of the three residents who received dental care, one is attending Gateway Technical College and entering her second semester, one is on her third semester at NKU and has been on the Dean's list all three semesters, and one is maintaining a full time job for the first time. Not only has the dental care for these three residents been a huge health benefit to them, it has also increased their self-esteem and occupational marketability.

\section{Ongoing Outreach Efforts}

CSS developed an incentive plan to encourage the remaining HOPE VI families to relocate successfully. Individuals or families who have had no contact with a CSS staff person were offered a $\$ 50$ gift certificate to meet with a specialist at least two times to develop a service plan or discuss the family's relocation plan. Since this plan was implemented in August 2005, 22 families have developed a service plan. In addition to developing these plans, a family may receive additional incentives by completing the following processes:

- Participants who attend a town meeting or group education session (such as the weatherization class held in November) will receive a $\$ 10$ gift certificate.

- Those who complete the "Money Matters" program will receive a $\$ 50 \mathrm{gift}$ certificate.

- Residents who begin financial counseling will be awarded a $\$ 25$ gift certificate for each session (estimated that 2-3 sessions may be needed).

- Those completing the "Yes, You Can! Classes" will receive a $\$ 50$ gift certificate. 
- Once residents have completed Money Matters and/or Yes, You Can! classes and begin to pay down existing debt, CSS will double the individual's payment to the creditor each month until either the debt is paid, the program ends, or funds are exhausted (ex., Resident pays $\$ 50$ toward a debt and CSS will pay $\$ 100$ ).

- Residents who purchase a home will be awarded a $\$ 500$ shopping spree to be used for home furnishings and household wares.

\section{Overall Project Effectiveness}

Brighton Center has sponsored quarterly HOPE VI Community Task Force meetings to encourage community and organizational support. In addition, monthly town meetings were held for residents in the CSS program to keep them informed of current developments. Since October 2002 , more than 70 residents have attended the monthly town meetings. Meetings were discontinued in April 2006 because many of the residents of HAN's north-site relocated prior to its demolition on June 30, 2006.

The goals of the CSS program were revised and clarified as of June 2004 (Gilderbloom, 2004). These goals are processes and not outcomes as defined by HUD (Popkin et al., 2000; Popkin et al., 2004; HUD, 1999; HUD, 2000). All 34 scheduled supportive services programs have been utilized. The NHA currently provides home maintenance classes that are given by the NHA maintenance supervisor upon purchase of a home. All 10 homeowners who have participated in Brighton Center's CSS program have completed this class. A total of 27 of the 34 ( 79 percent) support service participation processes have been completed or exceeded. Thirty-two of the 34 (94 percent) support service program processes have met or exceeded 50 percent of the 
processes. Nine of the 35 ( 29 percent) participation processes have been exceeded by over 100 percent.

The only processes that did not meet expectations were the Center for Employment Training (CET) such as the career training program; completing the CET program; CET participants obtaining full-time employment and full-time employment for nine months; CET participants being offered health insurance; the Housing Authority of Newport providing basic home maintenance to residents; and participating in the Northern Kentucky University (NKU) Entrepreneurship Center for Small Business. The success of meeting the participation processes is surprising in light of the decreases in families eligible for HOPE VI because of evictions or residents moving out of the area.

\section{Table 5.1}

CSS WORKPLAN PROCESSES-June 30, 2007

\begin{tabular}{|l|l|c|}
\hline Program / Activity & $\begin{array}{l}\text { Participation } \\
\text { Process }\end{array}$ & Participation to Date \\
\hline $\begin{array}{l}\text { Jobs Center / One Stop } \\
\text { Job Training Development }\end{array}$ & 25 Persons & $\begin{array}{c}58 \text { Persons } \\
\text { (Process exceeded) }\end{array}$ \\
\hline $\begin{array}{l}\text { Assist families with entering post-secondary } \\
\text { degree program / training }\end{array}$ & 7 & $\begin{array}{c}25 \\
\text { Process exceeded }\end{array}$ \\
\hline $\begin{array}{l}\text { Enroll residents in a certificate or degree } \\
\text { program @ NK Vo-Tech or NKU }\end{array}$ & 7 & $\begin{array}{c}10 \\
\text { Process exceeded }\end{array}$ \\
\hline $\begin{array}{l}\text { Residents will enroll in the Bureau of } \\
\text { Vocational Rehabilitation Program }\end{array}$ & 7 & 8 \\
\hline Career training through CET & 35 & 29 \\
\hline $\begin{array}{l}\text { Residents completing CET will obtain full- } \\
\text { time employment }\end{array}$ & 16 & 9 \\
\hline $\begin{array}{l}\text { Residents completing CET will obtain full- } \\
\text { time employment for 9 months }\end{array}$ & 12 & 9 \\
\hline $\begin{array}{l}\text { Residents completing CET will be offered } \\
\text { health insurance }\end{array}$ & 12 & \\
\hline
\end{tabular}




\begin{tabular}{|c|c|c|}
\hline Program / Activity & $\begin{array}{l}\text { Participation } \\
\text { Process }\end{array}$ & Participation to Date \\
\hline Residents will complete CET & 20 & 9 \\
\hline $\begin{array}{l}\text { Individuals will attend Newport Adult or } \\
\text { Community Learning Center }\end{array}$ & 25 & $\begin{array}{c}44 \\
\text { Process exceeded }\end{array}$ \\
\hline $\begin{array}{l}\text { Residents will obtain GED or increase } \\
\text { TABE by } 4 \text { grade levels }\end{array}$ & 12 & $\begin{array}{l}\text { Increase TABE: } 27 \\
\text { Received GED: } 13 \\
\text { Process exceeded }\end{array}$ \\
\hline $\begin{array}{l}\text { Youth will participate in the YLD/Summer } \\
\text { Youth program }\end{array}$ & 10 & $\begin{array}{c}18 \\
\text { Process exceeded }\end{array}$ \\
\hline Youth participation in YMCA activities & 30 & $\begin{array}{c}55 \\
\text { Process exceeded }\end{array}$ \\
\hline Form a girl scout troop & 10 Girls & $\begin{array}{c}21 \\
\text { Process exceeded }\end{array}$ \\
\hline $\begin{array}{l}\text { Youth participation in boys \& girl club } \\
\text { activities }\end{array}$ & 15 & $\begin{array}{c}42 \\
\text { Process exceeded }\end{array}$ \\
\hline Participation in W/A youth programs & 8 & $\begin{array}{c}8 \\
\text { Process exceeded }\end{array}$ \\
\hline $\begin{array}{l}\text { Participants awareness of childcare } \\
\text { availability and funding } \\
\text { Health Point will provide services to } \\
\text { families on a sliding scale fee }\end{array}$ & $\begin{array}{l}45 \\
60\end{array}$ & $\begin{array}{c}56 \\
\text { Process exceeded } \\
97 \\
\text { Process exceeded } \\
\end{array}$ \\
\hline Families will purchase a new residence & 10 & $\begin{array}{c}10 \\
\text { Process exceeded }\end{array}$ \\
\hline $\begin{array}{l}\text { First time moms will receive home visits } \\
\text { from every child succeeds }\end{array}$ & 10 & $\begin{array}{c}16 \\
\text { Process exceeded }\end{array}$ \\
\hline $\begin{array}{l}\text { Families will receive health insurance for } \\
\text { kids through K-chip }\end{array}$ & 10 & $\begin{array}{c}24 \\
\text { Process exceeded }\end{array}$ \\
\hline $\begin{array}{l}\text { Moms and babies will visit the healthy } \\
\text { moms and babies van }\end{array}$ & 15 & $\begin{array}{c}19 \\
\text { Process exceeded }\end{array}$ \\
\hline $\begin{array}{l}\text { Newport school based health center will } \\
\text { provide families with monthly care }\end{array}$ & 10 & $\begin{array}{c}28 \\
\text { Process exceeded }\end{array}$ \\
\hline $\begin{array}{l}\text { North key will provide mental health and } \\
\text { substance abuse serious to families }\end{array}$ & 15 & $\begin{array}{c}48 \\
\text { Process exceeded } \\
\end{array}$ \\
\hline $\begin{array}{l}\text { NHA maintenance department will provide } \\
\text { basic home maintenance } \\
\text { *Housing Authority Directed. }\end{array}$ & 20 & 3 \\
\hline $\begin{array}{l}\text { Participants will go through the NKU } \\
\text { Entrepreneurship Center for Small Business }\end{array}$ & 10 & 6 \\
\hline $\begin{array}{l}\text { Participants will receive HUD mortgage } \\
\text { counseling through } \mathrm{BC}\end{array}$ & 30 & $\begin{array}{c}33 \\
\text { Process exceeded }\end{array}$ \\
\hline $\begin{array}{l}\text { Participants will complete HUD mortgage } \\
\text { counseling through BC }\end{array}$ & 16 & $\begin{array}{c}21 \\
\text { Process exceeded }\end{array}$ \\
\hline $\begin{array}{l}\text { Families will receive budget counseling } \\
\text { through the CSS worker. }\end{array}$ & 40 & $\begin{array}{c}90 \\
\text { Process exceeded }\end{array}$ \\
\hline
\end{tabular}




\begin{tabular}{|l|l|c|} 
Program / Activity & $\begin{array}{l}\text { Participation } \\
\text { Process }\end{array}$ & Participation to Date \\
\hline Families have credit reports pulled & 40 & $\begin{array}{c}62 \\
\text { Process exceeded }\end{array}$ \\
\hline Families will resolve credit issues & 20 & $\begin{array}{c}38 \\
\text { Process exceeded }\end{array}$ \\
\hline $\begin{array}{l}\text { Families will receive transportation } \\
\text { assistance }\end{array}$ & 31 & $\begin{array}{c}50 \\
\text { Process exceeded }\end{array}$ \\
\hline $\begin{array}{l}\text { Families will be given information about } \\
\text { TANK routes, and increase usage of public } \\
\text { transportation }\end{array}$ & 20 & $\begin{array}{c}49 \\
\text { Process exceeded }\end{array}$ \\
\hline
\end{tabular}

\author{
Abbreviations Used in Table \\ BC: Brighton Center \\ TANK: Transit Authority of Northern Kentucky \\ YLD: Youth Leadership Program \\ CET: Center for Employment Training \\ CSS: Community Social Services \\ GED: Graduate Equivalency Degree \\ HUD: Housing and Urban Development \\ NHA: Newport Housing Authority \\ NK: Northern Kentucky \\ NKU: Northern Kentucky University \\ TABE: Test of Adult Basic Education
}

\title{
Survey Instrument Measuring Residential Satisfaction
}

I used a survey research instrument—included in Appendix A-that measured the residents' overall satisfaction with the program services provided to them through the HOPE VI case management services from Brighton Center, Incorporated, in Newport. Denise Govan, the Family Center Director of Brighton Center, and Mary Kitts, the Brighton Center Community and Supportive Services (CSS) caseworker, provided me with a list of $100 \mathrm{CSS}$ families, which represents the number of families active in the CSS program as of June 4,2007 . The list consisted of names of all CSS families with and without telephone numbers and their mailing addresses. 
The survey's six point scale ranges from strongly agree, agree, neutral (neither agree nor disagree), disagree, strongly disagree, and no answer. The first section consists of questions aimed at understanding the overall neighborhood and residential satisfaction of the HOPE VI residents with respect to the programs and services offered by Brighton Center's Community and Supportive Services (CSS) and the Housing Authority of Newport (HAN), and whether these programs and services have improved the quality of life of the individuals and families who participated. This section also measures the changes in the residents' satisfaction with their neighborhood, and the overall health of the neighborhood over the last seven years from the inception of the HOPE VI program in 2000 through the end of the CSS program in 2007, including whether there are more recreation activities for adults and children, more public transportation opportunities available, and better educational and employment opportunities in the new neighborhood and as result of the programs offered by CSS.

The survey also observed community residents perception of safety, community activity and gathered data about safe and affordable housing, including whether the residents felt their community is clean and the houses in the neighborhoods are wellmaintained, whether there is a presence of crime and drugs in the neighborhood, and whether the residents felt there are enough opportunities for safe and affordable housing, such as subsidized, Section 8 , and market-rate housing.

The surveys were administered throughout the month of June 2007. In addition, I submitted a study amendment request form to the Human Subjects Protection Program Office (HSPPO) at the University of Louisville on June 4, 2007, to update and amend our initial approval of our HOPE VI study in 2002. I received approval from this office the 
following week on June 11, 2007. The majority of our interviews were conducted over the telephone, through the assistance of Carrie Beth Lasley and Elizabeth McConnell, research assistants who worked on the HOPE VI evaluation grant team. Surveys not administered over the telephone or with residents who did not have a phone number were done in-person or by going door-to-door or to their home, even if that residents had moved outside of Newport. The survey instrument was approved by the Institutional Review Board (IRB) at the University of Louisville, which contained a statement guaranteeing each respondent's anonymity.

In-person interviews with CSS participants were conducted at the Brighton Center, Inc., offices of 799 Ann Street in Newport. All CSS participants, regardless of having a working telephone number or current mailing address, were notified by Brighton Center staff to stop by Brighton Center headquarters to complete the questionnaire. Door-to-door interviews were conducted in Newport on June 25, 2007, with families who live in the south site of the Housing Authority of Newport (HAN) public housing project. The north-site of the public housing projects toward the Ohio River and floodwall were demolished. All the families had moved out and relocated to the south site or other areas around Newport as of September 30, 2006. The door-to-door interviews were conducted with residents who had an address, but no telephone. Only a small number of residents who completed the door-to-door survey had a telephone. The residents we could not reach door-to-door or in-person received follow up calls at a later date. We returned to Newport two weeks later to complete interviews we did not get before in the previous attempts. 
The survey was administered and completed by 54 out of the 100 families, resulting in a response rate of 54 percent, with 17 families were considered unknown or missing-in-action (MIA); meaning Brighton Center had no current contact information for them. Our aim was to get a 50 percent response rate, because 50 percent is adequate for analysis and reporting (Babbie, 2004, 261).

The survey is approximately six pages in length and divided into six sections of with a total of 55 questions using a six-point scale and five open-ended questions in the demographic section of the survey. Demographics included which asked the respondents' age, race, level of education, number of persons living in the household, and monthly household income. The results of the survey were manually entered using an Internet software survey program (See Appendix A for Survey).

\section{Table 5.2}

Demographic Table of HOPE VI Residents

\begin{tabular}{|r|r|r|}
\hline & Response Count & Response Percent \\
\hline White/Caucasian & 37 & \\
African-American & 14 & $68 \%$ \\
Native American & 2 & $26 \%$ \\
Other & 1 & $4 \%$ \\
\hline Gender & & $2 \%$ \\
Male & 6 & $11 \%$ \\
Female & 48 & $89 \%$ \\
\hline Number of Persons in & & \\
Household & & $28 \%$ \\
1 & 15 & $28 \%$ \\
2 & 15 & $9 \%$ \\
3 & 5 & $18 \%$ \\
4 & 10 & $9 \%$ \\
5 & 5 & $4 \%$ \\
6 & 2 & $4 \%$ \\
\hline 7 & 2 & \\
Completed & & $7 \%$ \\
\hline Lighest Level of Education & & \\
Coss than $\mathbf{8}^{\text {th }}$ grade & 4 & \\
\hline
\end{tabular}




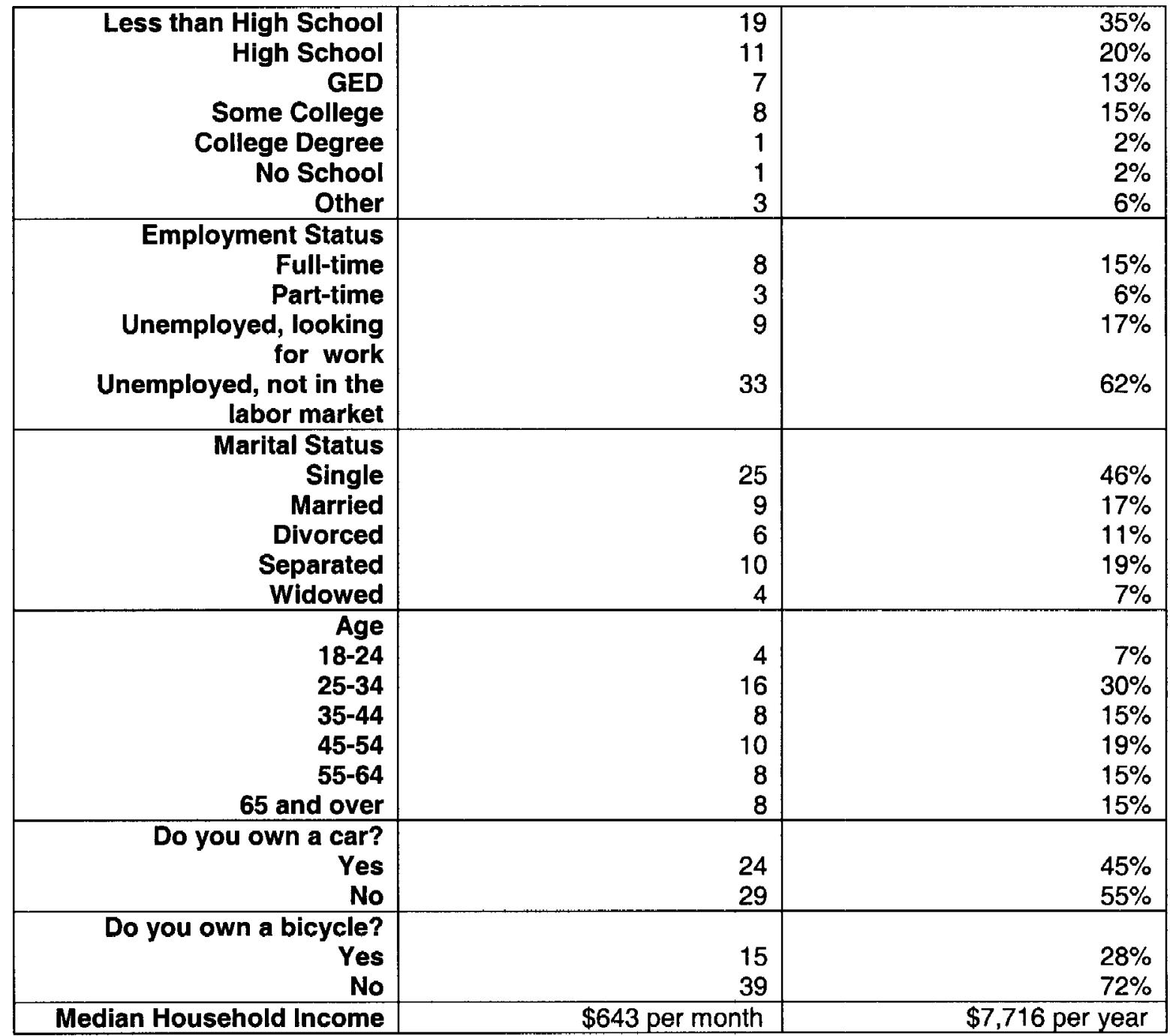

$\mathrm{N}=54$

The demographic data shown in Table 5.2 confirms the majority of the families have a single white female as head of the household with a mean age of 44 years old and the majority of respondents live in households with only one or two persons living there. Over two-third of the respondents surveyed are white, and over one-fourth are AfricanAmerican. These results are comparable to the racial composition of residents living in HOPE VI developments and the total public housing stock in Newport, 75 percent white and 25 percent African-American and minorities, according to George Darnell and Linda 
Fields of the Housing Authority of Newport (Linda Fields, personal communication, April 7, 2009: George Darnell, personal communication, April 7, 2009). The majority of the residents do not own a car or a bicycle. The majority of the residents have either a high school diploma or the GED high school equivalency diploma. The majority of the residents surveyed are unemployed and out of the labor force, many of whom are on disability or receive Social Security income. The median household income is $\$ 643$ per month, or roughly $\$ 7,716$ per year.

\section{Analysis to Survey Responses}

In terms of neighborhood satisfaction, the overwhelming majority of respondents believed that the Housing Authority of Newport and the Brighton Center CSS program have helped to improve their situation. These respondents believed that HAN and Brighton Center are doing a good job and have improved their quality of life. When asked if residents had an opportunity in the future to move out of their current neighborhood, a majority answered that they would wish to move. This may indicate that residents seek to improve their current situation, find a permanent home that they may someday own, or simply relocate to a different neighborhood or community due to their personal choices.

Those who would prefer to stay in their current neighborhood and purchase their home may do so because the families are in a favorable financial situation to be able to

purchase and own a home. These respondents could have strong community ties and identify with their current neighborhood or they may have uncertainty about where they would move if presented with the opportunity. 
Overall, residents have pride in their communities where a majority of residents have attended festivals and/or meetings in their community. However, a large majority of residents do not belong to a community organization or group. The lack of participation and involvement in a civic or community group or organization may be attributed to the decline in social capital in a community, which is defined as "connections among individuals- social networks and the norms of reciprocity and trustworthiness that arise from them" (Putnam, 2000, 19).

Social capital is important for a community because individuals and groups benefit from their contact and involvement in social networks. High levels of social capital result in higher levels of civic involvement from individuals who are involved in civic activities. Social capital has internal effects, which are the qualities that the citizens gain from participation in local and neighborhoods affairs, such as civic-mindedness, cooperation, and public-spiritedness (Putnam, 2000, 338-342). Also, many families in CSS have jobs, and many of them are on disability, which will impact whether that family and the family members are involved in the community.

In terms of community safety, the overwhelming majority of survey respondents agree that diverse people from different backgrounds and cultures live in their neighborhoods, and that they relate well with their neighbors. A significant number of respondents with children feel comfortable allowing children to play outside. Residents feel safe in their neighborhoods on points of adequate street light at night and police presence. Although residents perceive more drugs in their neighborhoods than in 2000, the majority of residents feel like gun violence and graffiti has decreased in their neighborhoods. 
According to the survey, a majority of residents agree and strongly agree that their community is clean and houses in their neighborhoods are well-maintained. A majority of residents agree that there are more opportunities for safe and affordable housing, such as subsidized, Section 8, and market-rate housing. A majority of residents agree that Brighton Center's Community Support Services (CSS) have improved residents' job skills, educational opportunities, and employability by helping develop resume and interview skills. In terms of the childcare services and programs offered by Brighton Center, many of the families responded with "no answer." Although Brighton Center offers various childcare opportunities, many respondents did not have children, and thus would not need to utilize these services. Overall, the majority of the residents are satisfied with services which help gain employment and improve education, but more importantly, an overwhelming majority of respondents agree that Brighton Center's CSS has improved their quality of life.

One hundred residents commented about their experiences in Brighton Center's CSS. The comments were positive and complimentary of the programs at Brighton Center and the Housing Authority of Newport. Mary Kitts and Sharon Stantzell, the CSS caseworkers in the Brighton Center, received considerable positive feedback. Their work with the program ended on June 30,2007 , but their impact on these residents is tremendous. One respondent said:

Other than being concerned about individual financial matters, they were also concerned about a person's welfare and well-being. I enjoyed working with them, 5 stars.

Another respondent said: 
I appreciate the people that have helped me along the way. Mary Kitts at the Brighton Center was very good and helpful. I appreciate everything Brighton Center has done over the years for me!!

One respondent said:

Is there anything you can do to get more time in the program? Some people have more issues than four years or 7 years will fix. Everyone is sad to see Mary go. People get health issues or other things that get them stuck. Mary is more than a social worker. She's a friend, like a family member. Mary would take me to appointments. She looks out for me. I don't see why CSS has to end.

The CSS program has had an enormous and profound impact on the lives of individuals and families where they gained value to help them become better workers, employees, parents and citizens. One participant reflected on her experience with Brighton Center CSS:

This program changed me and it should be able to continue to help people become independent. It helped me get educated and taught me about safety. I love the program; love the people I worked with. . . . My kids enjoy just getting to be kids. No one can steal their bikes because they're in their yard. ... They have a house now, and they need to share it with other kids who don't have a house. They invite other at-risk kids over all the time, and the kids really enjoy being able to do that. I hope they (people in the program) get something more from this or something similar. There's so many who need this, who this can help them. Everyone around here is trying to get by and is going about it the wrong way. Now that I know the way I try to get out there and help people do things the right way.

Overall, the participants in the Brighton Center's CSS programs and the HOPE VI housing project are satisfied with the services HAN and Brighton Center provided. They agree that both agencies are doing a good job. The residents overwhelmingly agree that they have more educational and employment opportunities, especially from the services offered at Brighton Center. The resident's lives are better because the Housing Authority of Newport and Brighton Center have provided the services, the skills, tools, and selfesteem to be able to move out and become employable, productive members of their 
community. These families took classes to learn how to manage credit and debt, and to learn how to be stronger people and citizens. The programs and services provided by HAN and CSS have given these families the opportunity to own their home and become stakeholders in the community, and help them turn around the community in which they live.

While this chapter measured and analyzed the impact of HOPE VI's Community and Supportive Services (CSS) on the satisfaction of residents, and analyzes the impact of HOPE VI on crime in the old public housing areas and new HOPE VI areas, the next chapter will analyze the impact of HOPE VI on property values by comparing HOPE VI and non-HOPE VI neighborhoods using a quasi-experimental design. 


\section{CHAPTER VI}

\section{ANALYSIS OF PROPERTY VALUES IN NEWPORT, KENTUCKY}

This chapter will examine and analyze the economic revitalization of Newport by looking at business and economic growth in the city, and the changes in property values in HOPE VI neighborhoods and neighborhoods throughout Newport.

\section{Property Value Data Analysis}

One result of the economic revitalization that occurred in Newport is through the increase in property value changes in HOPE VI neighborhoods. In the quasiexperimental design comparison, Saratoga Street and the Liberty Row represent the neighborhoods with a high concentration of HOPE VI development properties. The East Row Historic District and an area in Southwest Downtown Newport are the control and chosen to represent the non-HOPE VI neighborhoods. The East Row Historic District was chosen to help evaluate the effects of historic preservation districts on property values, while the Southwest Downtown area was recommended by the Housing Authority of Newport as an area of similar composition and value to the HOPE VI neighborhoods.

Information from the Campbell County Property Valuation Administrator (PVA) was used to study the change in property values from 2000 to 2007. ArcMap shapefiles were provided for the lots in the study by the PVA. Training was provided to the research team on the HOPE VI evaluation grant by the Campbell County PVA office on how to use the public information on their web site (www.campbellpva.com). 
Assessed values were used to determine property values for the years 2000 and 2007. These years are the years under study, and most lots were assessed in those years. For those that were not assessed in those years, the assessed values for the closest previous year were used. Lots not assigned a property identification number were listed in the data as 0 ; and therefore, the data is skewed slightly downward.

\section{Saratoga: HOPE VI Neighborhood}

The area identified as the HOPE VI Saratoga area runs from Seventh Street to the north to Sixth Street to the south and contains both sides of the border streets. The east side of Saratoga Street makes the eastern border, and the western side of Washington Street is the western border. It is just east of downtown and is located in the historic district. This area includes 118 property lots, 11 of which are HOPE VI properties as of June 2007 , or approximately nine percent of the total properties in the neighborhood (see Figure 6.1).

Over the seven-year study period, the median gain in property value was $\$ 124,750$, while the median percentage increase was 520 percent. Property values in the Saratoga area range from $\$ 5,000$ on 620 Saratoga Street empty lot to $\$ 2,896,865$ at a commercial property also known as Watertower Square at 601 Washington Street. The median property value in 2007 was $\$ 148,750$, compared to the median property value of $\$ 24,000$ in 2000 . Only two lots experienced a loss in value: 630 Washington Avenue and 639 Dayton Street. The majority of properties (79) experienced at least a doubling of the assessed value. All HOPE VI properties experienced a minimum of a 100 percent increase in value. 


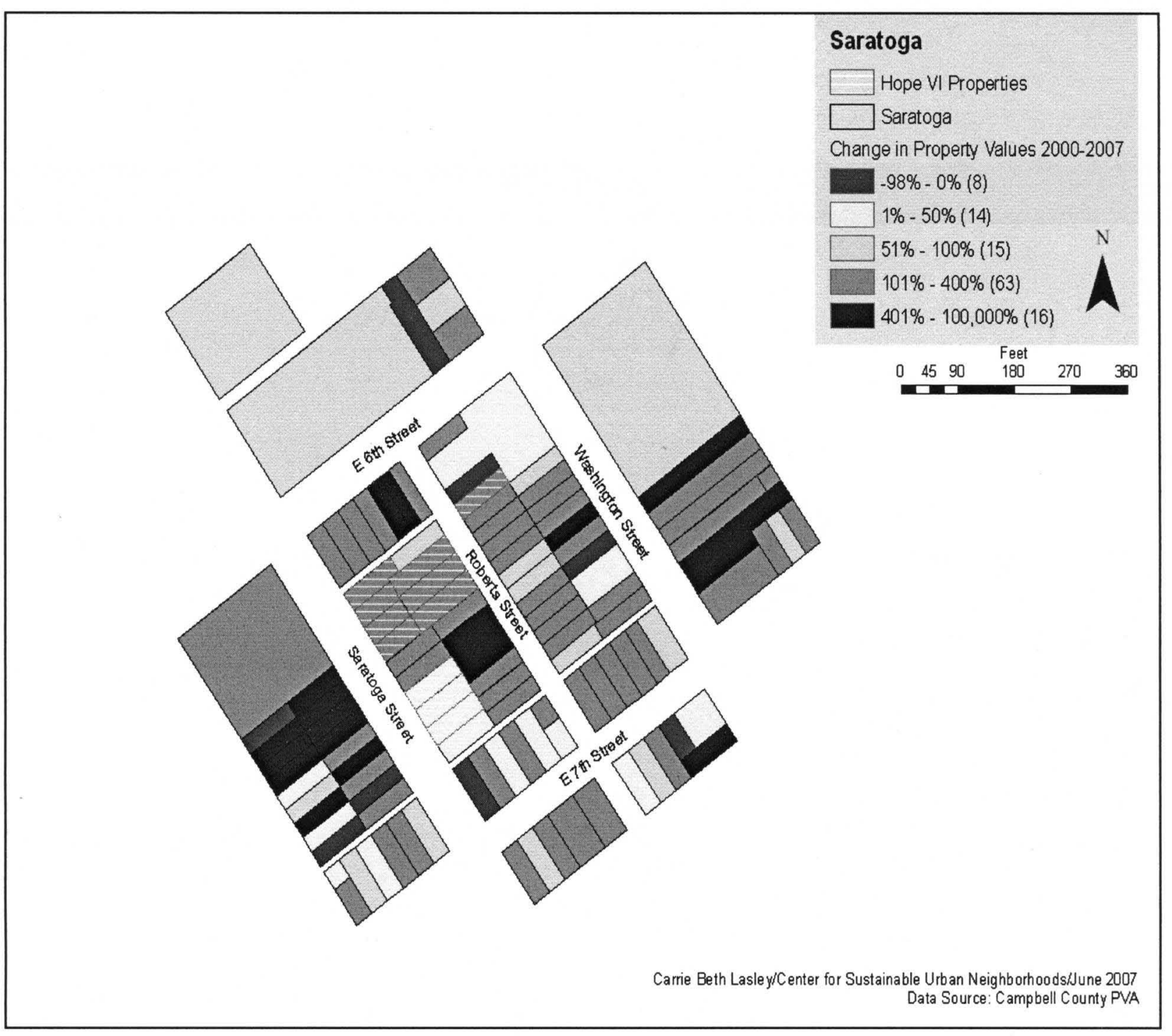

Figure 6.1. Changes in property values on Saratoga Street, 2000-2007.

\section{Liberty Housing: A HOPE VI Neighborhood}

Over the seven-year study period, the median gain in property value was 94

percent in the Liberty Row neighborhood. In that period, nine properties lost value; five were a result of improvements being torn down in preparation for re-development, and two were subdivided from another lot. The majority of property value increases occurred 
in or near the HOPE VI developments. The increases in percentage property-value change are lower the farther away from the new HOPE VI housing. The houses removed to make room for HOPE VI housing were low quality, so the mid-range housing put in its place resulted in a larger increase in value.

The map on the next page shows the areas identified as Liberty Housing, which includes the Liberty Row I and Liberty Housing (Liberty Row II) developments of the HOPE VI program and surrounding areas. This area runs from the west side of Patterson Street to the west to the east side of Central Avenue to the east. The northern border is the south side of West Seventh Street, and the southern border is the north side of West Ninth Street and is west of the Central Business District. Numbers in parentheses on the map on the next page represent the number of properties that fall into that category.

There are 310 property lots in this study area, 67 of which are HOPE VI properties, or approximately 22 percent of the total number of properties in the neighborhood. In the assessed study area, property values range from $\$ 1,700$ on a small undeveloped lot at 706 Central Avenue to $\$ 1,547,650$ at the Brighton Center Family Center at 799 Ann Street. The median property value was $\$ 49,000$ in 2007 , while the median property value in 2000 was $\$ 25,273$. 


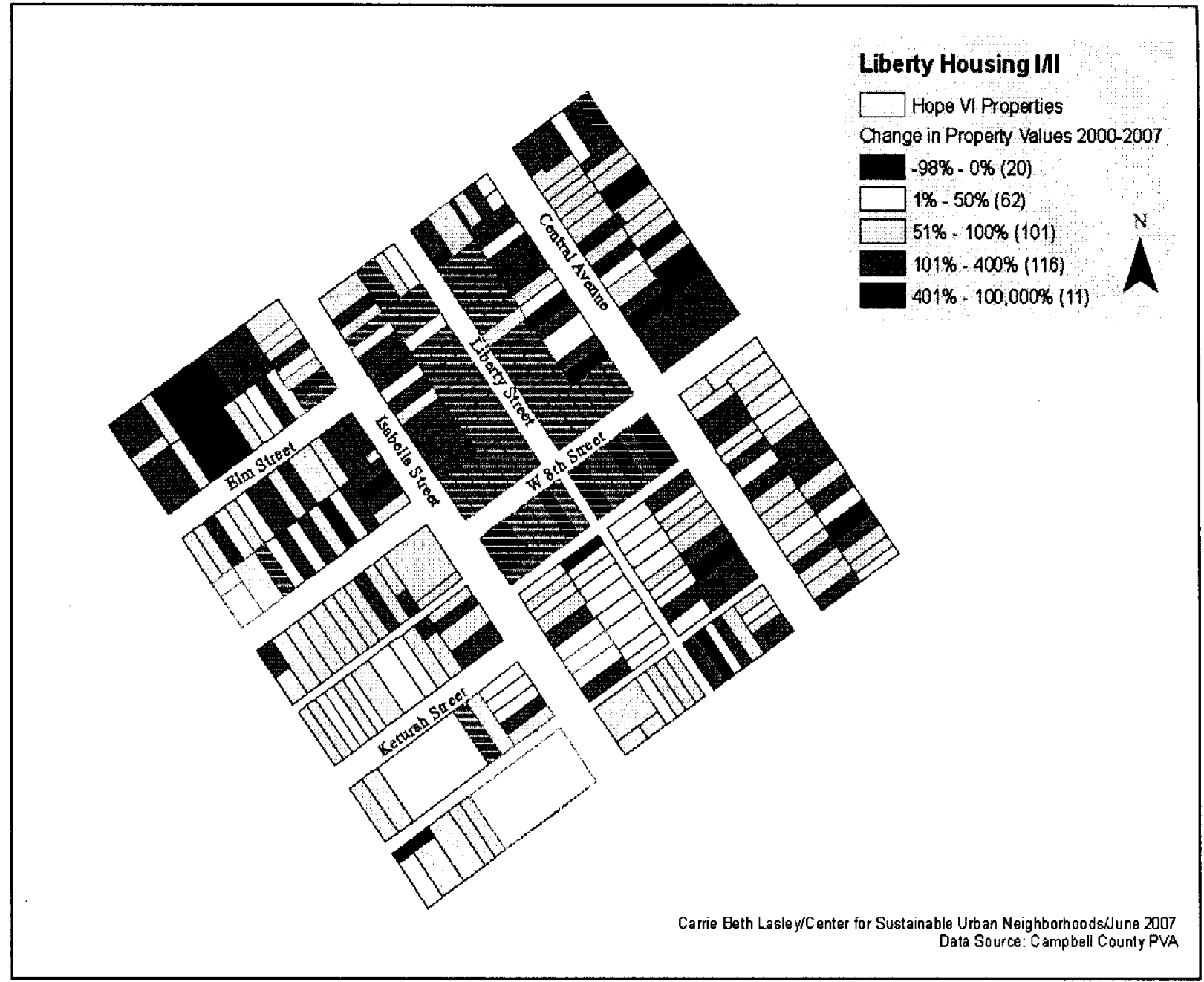

Figure 6.2: Liberty Row Housing I/II

\section{East Row: No HOPE VI, Historic District}

Over the past seven years, gains in property values increased by 136 percent, 42 percent higher than in Liberty Row with the HOPE VI intervention. There are 56 properties in this study area and no HOPE VI lots. Values in the area range from $\$ 10,800$ at an empty lot at 319 East Sixth Street to $\$ 925,000$ at the Mansion Hill property at 302-304 East Third Street. The median property value was $\$ 159,250$ in 
2007 , compared to $\$ 67,500$ in 2000 . While all properties experienced an increase in values, the increase was slightly more pronounced in the entirely residential blocks. Some of the homes are now going for $\$ 500,000$ in some areas of the East Row Historic District, compared to $\$ 40,000$ to $\$ 80,000$ a decade ago.

A portion of the East Row Historic District is represented in the map below. The study area runs from the south end of Third Street in the north to the north end of Sixth Street in the south. The east border is the west side of Washington Street, and the west border is the west side of Overton Street.

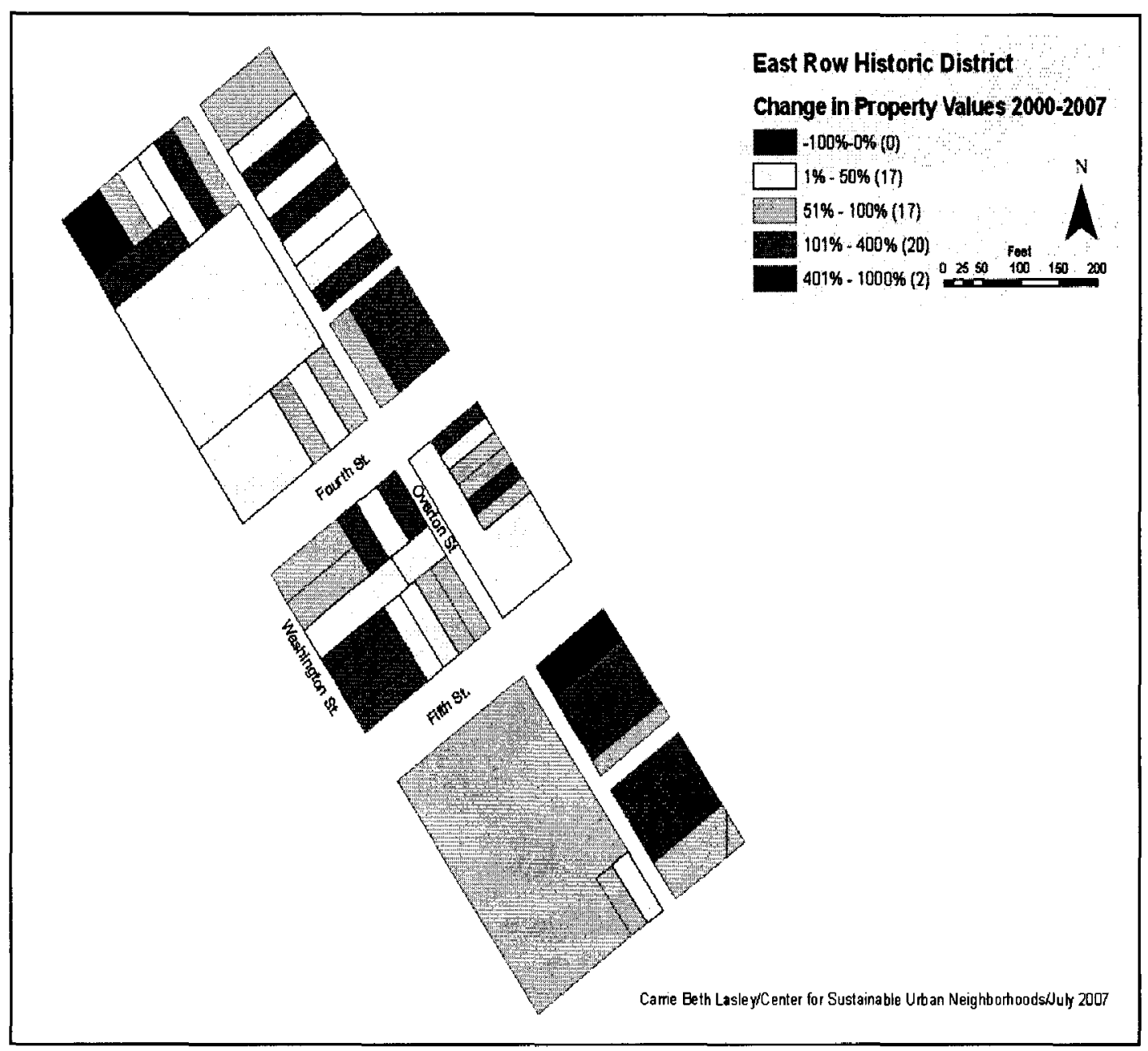

Figure 6.3. Changes in property values in East Row Historic District. 


\section{Southwest Downtown: No HOPE VI and No Historic Preservation}

In this area, property values increased an average of $\$ 21,140$, and the median percentage gained was 75 percent. The Southwest Downtown shows moderate increases in property values. This sample includes 112 lots, none of which are HOPE VI properties. The least expensive lot is valued at $\$ 10,800$ at 932 Brighton Street. The Northern Kentucky Headstart property at 502 West Ninth Street is valued at $\$ 1,187,600$. The median property value is $\$ 49,500$ in 2007 , and the median value in 2000 was $\$ 28,360$. Only one property in this area lost value, but more than two-thirds of the properties (68 percent) experienced gains of up to 100 percent.

The map on the following page shows changes in property value for an area of southwest downtown Newport that is similar to the Saratoga and Liberty Row and Liberty Housing developments, according to George Darnell, HOPE VI Coordinator for the Housing Authority of Newport. This area runs from Lowell Street in the west to Brighton Street in the east and from Ninth Street in the north to $12^{\text {th }}$ Street in the south. 


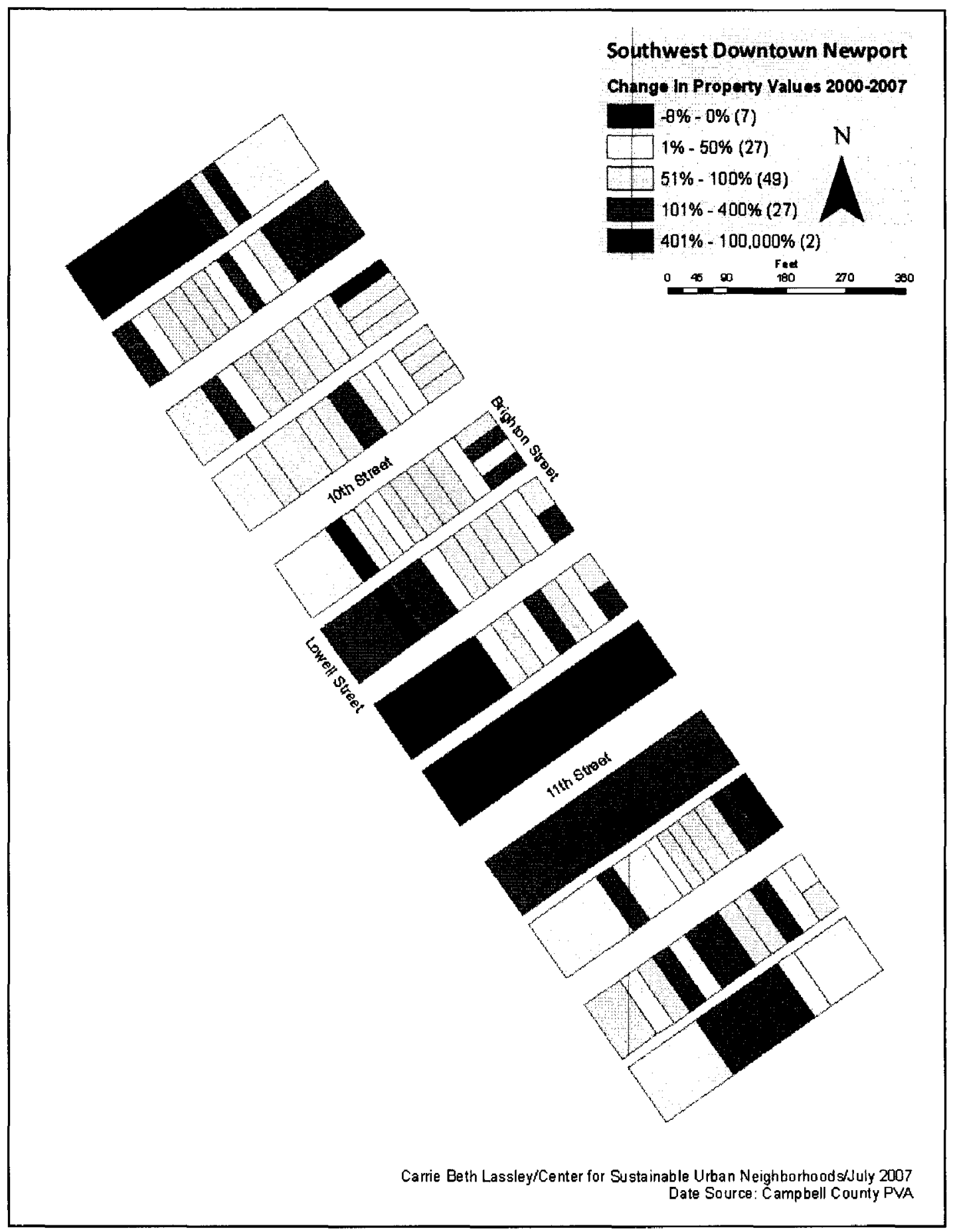

Figure 6.4. Change in property values in Southwest Downtown. 


\section{Comparing the Study Areas}

A comparison was undertaken to determine if the presence of HOPE VI have had an effect on property values. Data reflected on Table 6.1 on the next page indicates changes in median and mean property values in 2000 and 2007 in the HOPE VI and nonHOPE VI neighborhoods, using both raw dollar changes and percentage changes.

The presence of new HOPE VI housing has not had a negative impact on property values. Although the total dollars increase was higher in the East Row, the median housing value increased more dramatically than Saratoga Street by percentage change. The presence of HOPE VI has had the greatest positive effect on the median and mean numbers, which is caused by an increase in property value on the properties in the neighborhood with the lowest values and a more uniform increase across all properties.

Saratoga Street, which has both HOPE VI properties and is located in a historic preservation district, showed the largest increase in value. Saratoga Street experienced approximately four times the increase in median value by percentage ( 520 percent) than the non-HOPE VI neighborhood in the East Row Historic District (136 percent). The Southwest Downtown, non-HOPE VI neighborhood experienced an increase of 75 percent in median property values, less than both HOPE VI neighborhoods.

However, the East Row Historic District, the other neighborhood without the HOPE VI intervention, experienced higher property value increases (136 percent) than the HOPE VI neighborhood Liberty Row (94 percent), but a much smaller increase than Saratoga Street HOPE VI neighborhood (520 percent). One possible explanation of this anomaly is the quality of life and architectural integrity of the designated neighborhoods is greater than non-designated neighborhoods, including HOPE VI, and could have an 
effect on homeowners benefiting from higher property values in these areas (Gilderbloom, House, and Hanka, 2008).

Table 6.1

Ranges in Property Values between HOPE VI and Non-HOPE VI Neighborhoods

\begin{tabular}{|c|c|c|c|c|}
\hline & Saratoga & Liberty & East Row & Southwest \\
\hline HOPE VI & Yes & Yes & No & No \\
\hline Historic District & Yes & No & Yes & No \\
\hline Range High (2007) & $\$ 2,896,865$ & $\$ 1,547,650$ & $\$ 925,000$ & $\$ 1,187,600$ \\
\hline Range Low (2007) & $\$ 5,000$ & $\$ 1,700$ & $\$ 10,800$ & $\$ 10,800$ \\
\hline Median (2007) & $\$ 148,750$ & $\$ 49,000$ & $\$ 159,250$ & $\$ 49,500$ \\
\hline Mean (2007) & $\$ 111,734$ & $\$ 57,839$ & $\$ 198,632$ & $\$ 63,158$ \\
\hline Median (2000) & $\$ 24,000$ & $\$ 25,273$ & $\$ 67,500$ & $\$ 28,360$ \\
\hline Mean (2000) & $\$ 52,547$ & $\$ 31,888$ & $\$ 108,724$ & $\$ 39,430$ \\
\hline Mean Change & $\$ 59,187$ & $\$ 25,951$ & $\$ 89,908$ & $\$ 23,728$ \\
\hline Median Percent Change & $520 \%$ & $94 \%$ & $136 \%$ & $75 \%$ \\
\hline Mean Percent Change & $113 \%$ & $81 \%$ & $83 \%$ & $60 \%$ \\
\hline
\end{tabular}


In an effort to give a better sense of these percentage increases in these neighborhoods, we compare property value changes with the two HOPE VI and two nonHOPE VI neighborhoods in our quasi-experimental design comparison with rest of the city of Newport, Covington, Cincinnati, and the Cincinnati metropolitan area. I use median assessed value data for 2000 and 2007 and average sales price from the Greater Cincinnati and Northern Kentucky Board of Realtors, and the Northern Kentucky Area Development District (NKADD).

According to Table 6.2 on the following page, besides the large increases in the HOPE VI and non-HOPE neighborhoods, percentage changes in property values by percent were lowest in the city of Cincinnati and the Cincinnati metropolitan area at 17 percent, slightly less than Newport as a whole and Covington with 18 and 21 percent, respectively. The HOPE VI and control neighborhoods experienced property value increases ranging from four to thirty times higher than the comparable cities in the region. 
Table 6.2.

Changes in Property Values in Cincinnati Metropolitan Area, 2000-2007

\begin{tabular}{|c|c|c|c|c|c|c|}
\hline & $\begin{array}{l}\text { Median } \\
\text { Assessed } \\
\text { Value } \\
(2001)\end{array}$ & $\begin{array}{l}\text { Median } \\
\text { Assessed } \\
\text { Value } \\
(2007)\end{array}$ & $\begin{array}{l}\text { Percent } \\
\text { Change }\end{array}$ & $\begin{array}{l}\text { Mean } \\
\text { Sales } \\
\text { Price } \\
(2001)\end{array}$ & $\begin{array}{l}\text { Mean } \\
\text { Sales } \\
\text { Price } \\
(2007)\end{array}$ & $\begin{array}{l}\text { Percent } \\
\text { Change }\end{array}$ \\
\hline Covington & $\$ 65,500$ & $\$ 67,500$ & $3 \%$ & $\$ 71,447$ & $\$ 86,539$ & $21 \%$ \\
\hline Newport & $\$ 87,700$ & $\$ 89,000$ & $2 \%$ & $\$ 101,728$ & $\$ 120,440$ & $18 \%$ \\
\hline $\begin{array}{l}\text { Newport } \\
\text { HOPE VI } \\
\text { areas }(2000)\end{array}$ & & & & & & \\
\hline Saratoga & $\$ 24,000$ & $\$ 148,750$ & $520 \%$ & $\$ 52,547$ & $\$ 111,734$ & $113 \%$ \\
\hline Liberty Row & $\$ 25,573$ & $\$ 49,000$ & $94 \%$ & $\$ 31,888$ & $\$ 57,839$ & $81 \%$ \\
\hline $\begin{array}{l}\text { Newport } \\
\text { Non-HOPE } \\
\text { VI areas } \\
(2000)\end{array}$ & & & & & & \\
\hline $\begin{array}{l}\text { East Row } \\
\text { Historic } \\
\text { District }\end{array}$ & $\$ 67,500$ & $\$ 159,250$ & $136 \%$ & $\$ 108,724$ & $\$ 198,632$ & $83 \%$ \\
\hline $\begin{array}{l}\text { Southwest } \\
\text { Downtown }\end{array}$ & $\$ 28,360$ & $\$ 49,500$ & $75 \%$ & $\$ 39,430$ & $\$ 63,158$ & $60 \%$ \\
\hline Cincinnati & $\$ 93,200$ & $\$ 132,800$ & $42 \%$ & $\$ 135,082$ & $\$ 157,655$ & $17 \%$ \\
\hline $\begin{array}{l}\text { Cincinnati } \\
\text { Metropolitan } \\
\text { Area }\end{array}$ & $\$ 116,500$ & $\$ 152,100$ & $23 \%$ & $\$ 153,908$ & $\$ 180,400$ & $17 \%$ \\
\hline
\end{tabular}

Sources: Cincinnati Multiple Listing Service (MLS), Greater Cincinnati Board of Realtors; Northern KY MLS, Northern Kentucky Board of Realtors; Northern Kentucky Area Development District (NKADD); www.city-data.com 


\section{Future Development Plans in Newport}

Developer Corporex, in collaboration with architect HOK, have laid plans for a proposed $\$ 800$ million redevelopment of Newport's riverfront at the confluences of the Ohio and Licking Rivers that will be seen as a "community we wish to leave for our children and grandchildren" (Ovation Powerpoint, 2007). Over the next 10-15 years,

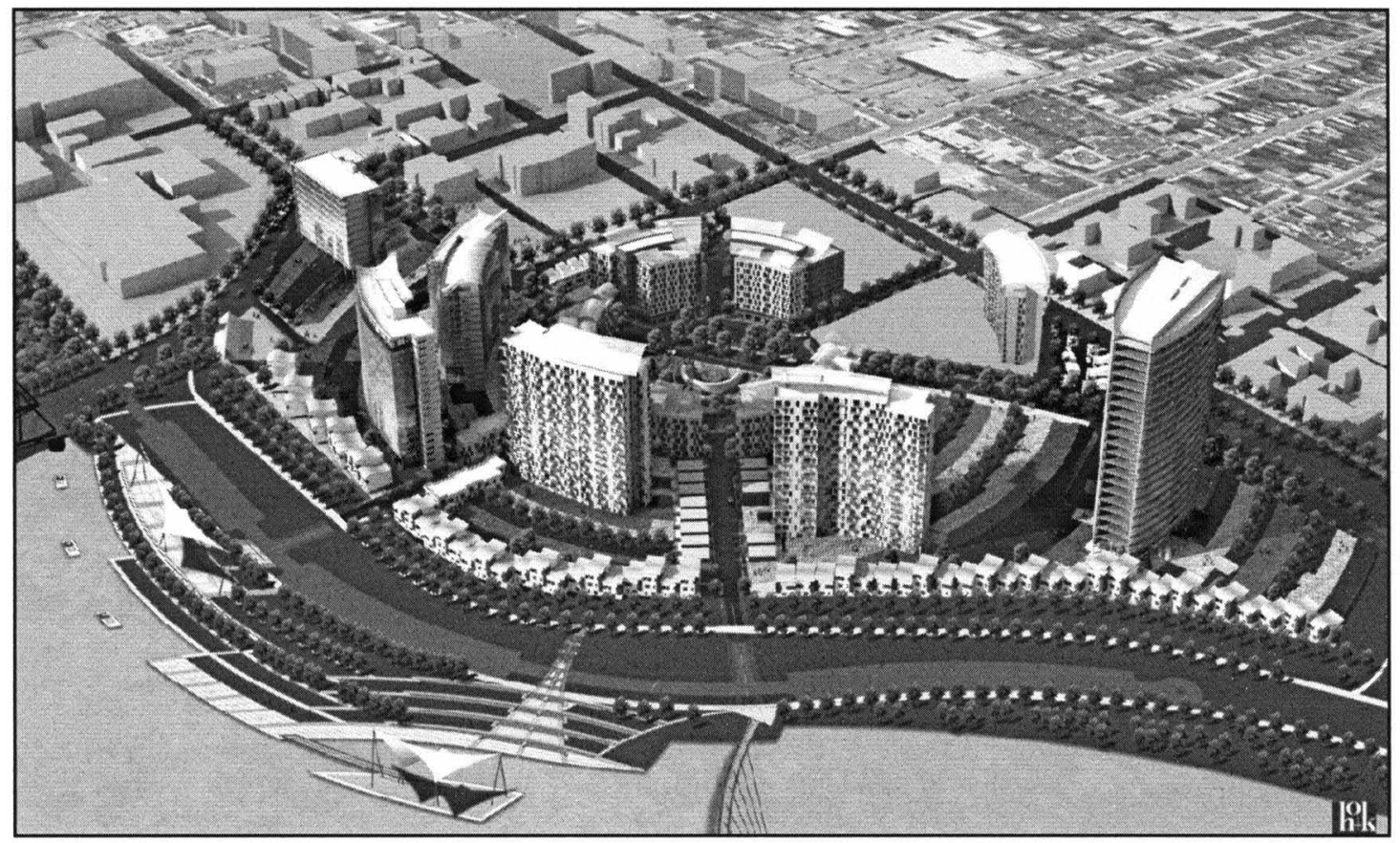

Figure 6.12. Ovation Development along Newport's Riverfront. 


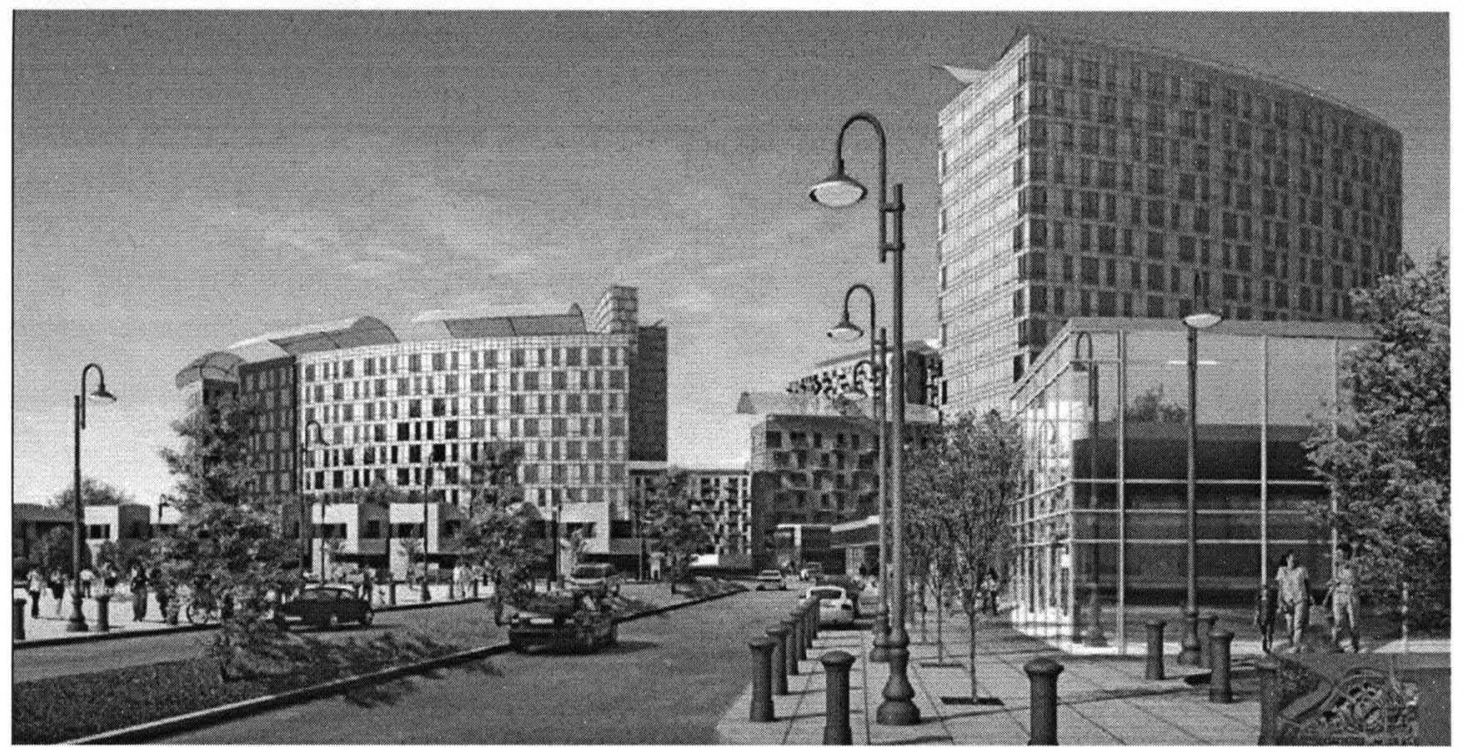

Figure 6.13. Ovation Development along Newport's Riverfront.

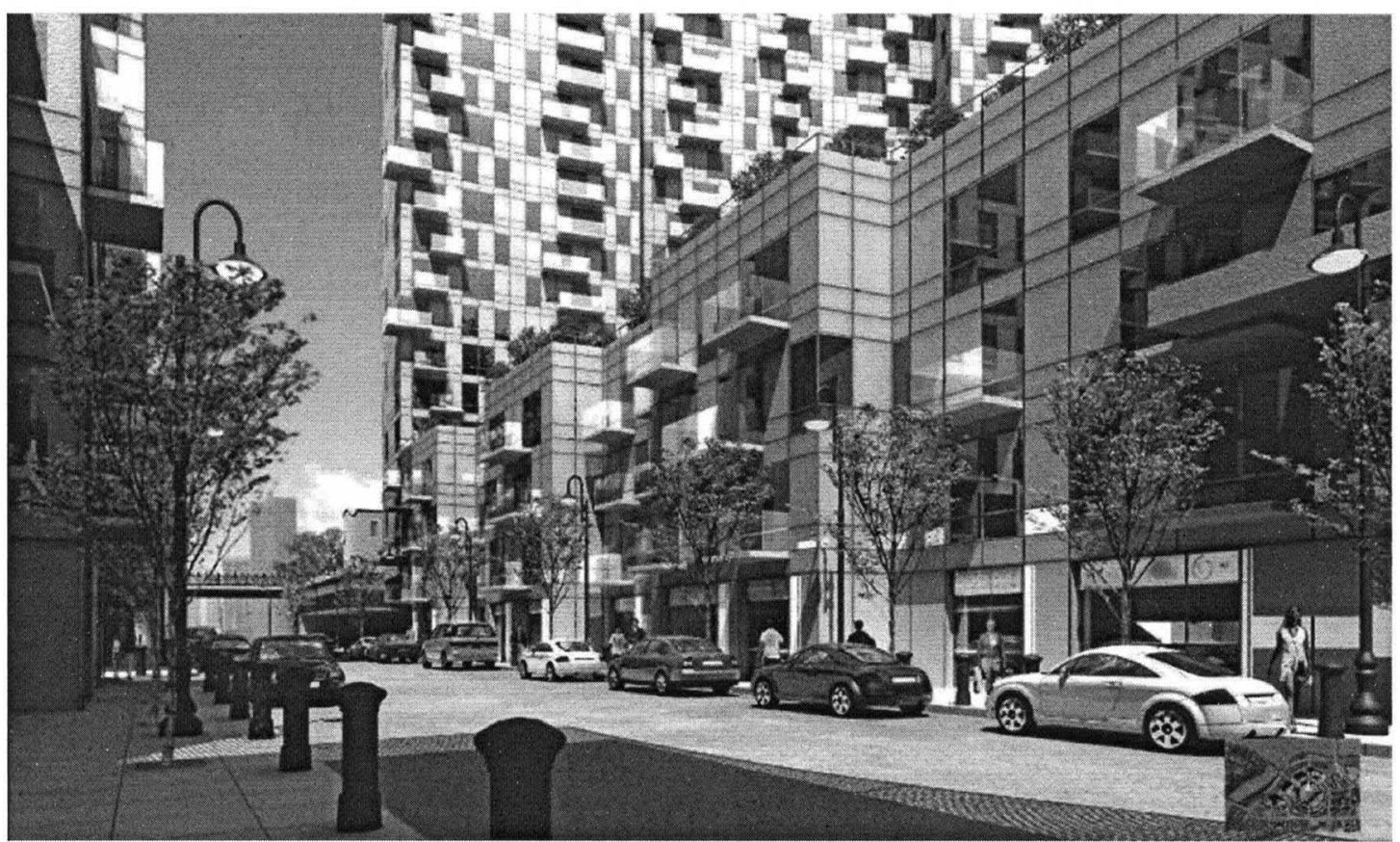

Figure 6.14. Ovation Development along Newport's riverfront. 
the Ovation property will offer a first-class, mixed use development, which includes approximately 300,000 to 500,000 square feet of large and small retail space. In addition, the development will include approximately 1.5 million square feet of office space, 1,000 housing units, a hotel, and additional amenities, including a post office, and hiking trails and riverfront parks and increased access points across the Ohio River into Cincinnati (Ovation Report, 2006).

The mixed-use, high-rise buildings in the Ovation development is intended to attract young professionals and families with single family homes, town homes, including the construction of 726 condominiums located in various mid-to-high rise structures, and 192 senior housing units. This development brings amenities within close proximity to housing making city living convenient. The Ovation will include transportation amenities, including more bus and trolley lines that will link the city with the rest of the region.

Ovation will include office space to accommodate various types of business. The dispersed office park will include five office buildings in total and is expected to create approximately 5,000 jobs. The office park will include one 25 -story office building, two ten-story buildings, and two one-story office buildings on the perimeter of the property.

Out of the approximately $\$ 800$ million investment in the Ovation project, the annual economic activity generated from the project through Northern Kentucky will be $\$ 42$ billion over 30 years, including $\$ 7.9$ billion during the construction phase and $\$ 1.7$ billion annually: $\$ 1.08$ billion of that is the total annual direct impact of the Ovation investment. $\$ 646$ million is the total indirect impacts per year (Ovation 
Report, 2006). Throughout the ten-year construction period of the Ovation property, 926 jobs will be created. In addition, the Ovation development and its properties will employ approximately 6,700 direct and indirect jobs to be created from Ovation business (Ovation Report, 2006, 2).

The Ovation development aims to generate $\$ 36.6$ million in tax revenue each year, $\$ 17.5$ million for the city of Newport, over $\$ 14$ million for the state, and over $\$ 5$ million for Campbell County. Over the next thirty years, Ovation estimates generating $\$ 428$ million in fiscal revenues for the city of Newport, $\$ 209$ million in revenues for the state, and $\$ 127$ million in total revenues for Campbell County, Kentucky (Ovation Report, 2006, 23-24). This adds up to almost one billion dollars in total tax revenue as a result of this development, a strong return from the initial $\$ 28$ million investment from the federal government on the HOPE VI grant. According to Campbell County Judge Executive Steve Pendrey, $\$ 30$ million coming into Northern Kentucky is big money.... HOPE VI was the stimulus for this revival."

Another economic development project in Newport is the SouthShore riverfront development less than a mile from downtown Cincinnati by the developer Capital Investment Group, in collaboration with the architect, Pappageorge/Haymes, Ltd. This development will include three 20 -story buildings with condominiums, an office tower, a marina and parking garages. Southshore will target middle-to-high income individuals and families into the downtown Newport area. Ryan Wyrick with the city of Newport's Economic Development Office has stated that the riverfront developments were made possible by the HOPE VI federal grant and the removal of the dilapidated public housing. He emphasizes that these current projects optimize the utilization of riverfront property 
and will bring money into the local economy, specifically tax revenue to pay for public services, such as fire and rescue, police and schools (Ryan Wyrick, personal communication, August 8,2007$)$.

Also, the Newport Pavilion, developed by Bear Creek Capital, located between Memorial Parkway and Carothers Road near Interstate 471, provides important amenities for individuals and families, including a grocery store, a home improvement mega-store, and a big-box retail store.

This chapter examined the positive impact of the presence of HOPE VI using a quasi-experimental design method comparing HOPE VI neighborhoods and non-HOPE VI neighborhoods. Median property values increased from 94 percent to 520 percent in areas within HOPE VI developments, such as Liberty Row and Saratoga Street, while median property values in the non-HOPE VI neighborhoods, East Row Historic District and Southwest Downtown, also showed median property value increases between 75 and 136 percent. This dissertation states that property values in areas that contained HOPE VI increased, yet one neighborhood without the HOPE VI intervention, the East Row Historic District, increased by 136 percent, which exceeded one neighborhood that contained HOPE VI developments, Liberty Row (94 percent).

The next chapter will compare the changes in property values over a seven-year period between the HOPE VI neighborhoods in Newport with the HOPE VI program in Louisville's Park DuValle neighborhood by performing a standard regression analysis using a larger sample and control variables, including HOPE VI as a dummy variable, to better understand HOPE VI's impact. 


\section{CHAPTER VII}

\section{A COMPARATIVE STUDY OF PROPERTY VALUES IN HOPE VI NEIGHBORHOODS IN NEWPORT AND LOUISVILLE'S PARK DUVALLE}

The last chapter examined and analyzed the impact of changes in property values in HOPE VI and non-HOPE VI neighborhoods and the potential impact of the Ovation development on the overall renewal and revitalization of Newport. In Newport, I did not have the proper control variables or a large enough sample to perform this statistical analysis. In this chapter, I have a much better sample of 170 neighborhoods in Louisville and better access to critical control variables to perform a regression analysis to look at the HOPE VI neighborhood in Louisville, Park DuValle, and compare it to the nonHOPE VI neighborhoods in the sample.

All science must begin with comparison, and only through comparison can we achieve greater certainty (Durkheim, 1982; Gilderbloom, Hanka, \& Lasley, 2008; Kantor \& Savitch, 2005). In this dissertation, I compare the impacts of the HOPE VI program in Newport and the Park DuValle HOPE VI program in the West End of Louisville. Although the Park DuValle program was observed for removing the concentration of poverty and increasing property values, the program has received criticism for its continued segregation of residents, the significant absence of many former public housing residents returning to the new HOPE VI developments, and the lack of connectivity of 
the residents in the new HOPE VI development with the greater community in Louisville (Brazley, 2002; Brazley \& Gilderbloom, 2007; Gilderbloom, 2008).

This analysis expands upon the work of Ambrosius, Gilderbloom, and Hanka, (2009) and Gilderbloom, Ambrosius, and Hanka (2008) by documenting the trend of property value appreciations over a seven-year period from 2000-2006 in a medium size city, Louisville, KY, and analyzing whether mid-sized cities like Louisville are moving toward successful megacities like New York, Los Angeles, and Chicago, or moving in the category of declining post- industrial cities like Buffalo, Cleveland, Detroit, and Newport's neighbor, Cincinnati.

Many of the studies analyzing historic tends in real estate only look at median housing values and raw changes in property values, which reveals certain information, but often paints an inaccurate and incomplete picture of the dynamics of contemporary housing markets. Using percent change as a measure of contemporary housing dynamics, which is basically the raw dollar change over housing value at the beginning of the period, which is the year 2000 , better captures contemporary housing dynamics (Gilderbloom, Ambrosius \& Hanka, 2008).

First, I show a bivariate relationship between percentage changes in property values and Table 7.1 shows the ten highest performing and 10 lowest performing neighborhoods in Louisville by census tract. Park DuValle, the neighborhood with HOPE VI in Louisville, ranks as having the highest percentage increase in neighborhood property values from 2000 to 2006 , compared to 169 other neighborhoods in Louisville without HOPE VI developments, which had an average increase of approximately 32 percent. 
Table 7.1

Property Value Appreciations by Census Tract in Louisville

\begin{tabular}{|c|c|}
\hline Highest Appreciations & Lowest Appreciations \\
\hline 1) Park DuValle (001400)- $240.99 \%$ & 1) Hikes Point $(010800)-17.43 \%$ \\
\hline 2) Russell (002400)- $113.12 \%$ & 2) Fairdale (012003)- $16.78 \%$ \\
\hline $\begin{array}{l}\text { 3) } \quad \text { Butchertown/ Phoenix Hill } \\
(005900)-97.4 \%\end{array}$ & 3) Hawthorne (009700)- $15.97 \%$ \\
\hline California (001800)- $87 \%$ & 4) Schnitzelburg (007000)- $15.86 \%$ \\
\hline Portland (002300)- $81 \%$ & $\begin{array}{l}\text { 5) Jacobs (near Churchill downs)- } \\
15.83 \%\end{array}$ \\
\hline Old Louisville/UofL (005300)- 76\% & Okolona (011904)- $15.74 \%$ \\
\hline Shively (012702)- $75.4 \%$ & 7) Hurstbourne (010705)- $13.77 \%$ \\
\hline Floyds Fork (011512)- $71.3 \%$ & 8) Hurstbourne (010701)- $12.28 \%$ \\
\hline 9) Russell (000600)- 69.73\% & 9) Okolona (011906)- $11.39 \%$ \\
\hline 10) Portland (000200)- $68.7 \%$ & 10) Northeast Jefferson (010307)- $10.2 \%$ \\
\hline
\end{tabular}

Source: (Gilderbloom, House, and Hanka, 2008)

In addition to a bivariate analysis, I ran a regression analysis comparing predicting property value appreciation using three different operationalizations and measurements of the dependent variable median housing value. These operationalizations of the dependent variable are (1) median housing value in 2006 measured in thousands of dollars, (2) raw dollar increases from 2000 to 2006 in thousands, and (3) percent change in property value from 2000 to 2006.

For example, if a home in the inner city neighborhoods of Louisville is valued at $\$ 100,000$ and experienced a $\$ 20,000$ increase in value, this would result in a 20 percent increase in property value, but if a $\$ 300,000$ home in the suburbs increases by $\$ 20,000$, this would result in an increase of less than seven percent, 13 percentage points less. In 
terms of percent, the increase in the suburbs is small, but it is much larger in the urban inner-city neighborhoods.

I ran a regression analysis partialing out the impact of HOPE VI on neighborhood housing values. The data in all residential properties for the years 2000 and 2006 came from the Jefferson County Property Valuation Administrator (PVA) and geocoded by the Kentucky State Data Center using the Louisville/Jefferson County Information Consortium's (LOJIC) GIS system. Median values and percentage increases were calculated for all 170 census tracts from the 2000 Census. My sample is 167 census tracts, and the remaining three census tracts 003000, (Louisville Central Business District), 004900 (City View Park) and 011901 (areas encompassing Louisville International Airport and the Kentucky State Fairgrounds) were removed due to insufficient residential units. ${ }^{1}$ Other studies (Greater Louisville Project, 2007; Bourassa et al., 2008) have eliminated two or three of these tracts due to lack of units or sales.

Previous studies (Ambrosius, Gilderbloom, \& Hanka, 2009; Gilderbloom, Ambrosius, and Hanka, 2008) have added variables measuring policy interventions, such as historic preservation and university-community partnerships. The goal of regression analysis is an attempt mathematically to explain variations in the dependent variable by entering experimental and control variables, such as HOPE VI, to partial out its impact. In Table 7.2, we list the variables we control for in neighborhood housing price variations. The table shows each variable controlled for, how it was operationalized, the

\footnotetext{
${ }^{1}$ Previous reports on these census tracts were misunderstood and concluded that these census tracts experienced losses (Green, 2007). While the recent airport expansion did destroy a large portion of housing stock which resulted in a decrease in tract 011901 , the other two tracts have seen a significant rise in residential development, which is still coded as commercial by the PVA. If one includes these multi-unit commercial entities as single residential units, the percentage increases exceed one-thousand percent in the CBD tracts over the last seven years. If we insert these cases into the regression, the results are nonsensical and isolating individual variables' effects becomes impossible.
} 
predicted direction of each independent variable's and its effect based on the literature, indicated with a plus (+) or minus -(-) sign, as well as the variable I am measuring, HOPE VI. We use two signs $(+/-$ or $-/+)$ to indicate volatile relationships. A question mark (?) shows relationships that I am unsure about or may have become non-significant over our analysis period (see Gilderbloom, Ambrosius, and Hanka, 2008).

Table 7.2. List of Independent Variables and their Predicted Directions

\begin{tabular}{|c|c|c|c|c|}
\hline & $\begin{array}{l}\text { Median } \\
\text { Housing } \\
\text { Value, } \\
2006\end{array}$ & $\begin{array}{c}\text { Raw } \\
\text { Dollar } \\
\text { Change } \\
2000- \\
2006\end{array}$ & $\begin{array}{c}\text { Percent } \\
\text { Change } \\
2000- \\
2006\end{array}$ & Sources \\
\hline $\begin{array}{l}\text { Median household } \\
\text { income }(000 \mathrm{~s})\end{array}$ & + & + & + & $\begin{array}{l}\text { Case \& Mayer 1996; Archer, et al. } \\
1996\end{array}$ \\
\hline Percent nonwhite & - & - & $?$ & $\operatorname{Kim} 2000$ \\
\hline Vacant housing percent & - & - & ? & Li \& Rosenblatt, 1997 \\
\hline Rental Percent & - & - & - & $\begin{array}{l}\text { Gilderbloom and Appelbaum, } \\
\text { 1988; Gilderbloom and Ye, } 2007\end{array}$ \\
\hline Median housing age & - & $?$ & - & Archer, et al. 1996 \\
\hline Unemployment & - & - & - & Lauria, 1998; Lauria, 2000 \\
\hline Population Density & $\begin{array}{l}\stackrel{-/+}{\text { (negative/ }} \\
\text { positive) }\end{array}$ & $?$ & $?$ & $\begin{array}{l}\text { Logan \& Molotch, 1987; Burgess, } \\
\text { 1925; Alonso, 1964; Mills, 1972; } \\
\text { Muth, } 1969\end{array}$ \\
\hline Crime level & - & - & - & $\begin{array}{l}\text { Lynch \& Rasmussen 2001; Case } \\
\text { \& Mayer } 1996\end{array}$ \\
\hline HOPE VI neighborhood & - & + & + & $\begin{array}{l}\text { Gilderbloom, Hanka, Lasley, } \\
\text { 2008; Gilderbloom } 2008\end{array}$ \\
\hline
\end{tabular}




\section{Table 7.3}

Descriptive Statistics

Mean Median $\quad \begin{array}{lll}\text { Std } & & \\ \text { Dev } & \text { Range Min } \quad \text { Max }\end{array}$

Median housing value in $\$ 1000$ s, 2006 (\$)

$\begin{array}{llllll}118.106 & 105 & 61.147 & 301.64 & 32.125 & 333.765\end{array}$

Raw $\$$ change in median housing value in $\$ 1000$ s, 2000-06 $\begin{array}{llllll}28.24 & 23.535 & 16.275 & 76.985 & 8.9 & 85.885\end{array}$

Percent change in median housing value, $00-06(\%)$

$\begin{array}{llllll}35 & 30.5 & 22.9 & 230.8 & 10.2 & 241\end{array}$

Median household income, $00(\$)$

$\begin{array}{llllll}40.951 & 37.561 & 19.387 & 104.386 & 6.086 & 110.472\end{array}$

Percent nonwhite, $00(\%)$

$\begin{array}{llllll}24.82 & 10.66 & 29.05 & 98.06 & 1.37 & 99.43\end{array}$

Vacant housing percent, $00(\%)$

$\begin{array}{llllll}6.38 & 4.88 & 3.92 & 17.26 & 1.79 & 19.05\end{array}$

Rental percent, $00(\%)$

$\begin{array}{llllll}35.4 & 33.43 & 20.76 & 90.92 & 3.0 & 93.92\end{array}$

Median housing age,

00 (years)

38.8

$\begin{array}{llllll}8.8 & 39 & 15.2 & 58 & 2 & 60\end{array}$

Unemployment, $00(\%)$

5.9

4.1

5.3

31.6

$\begin{array}{ll}1.1 & 32.7\end{array}$

Population density, 00

$\left(\right.$ per $\left.\mathrm{mi}^{2}\right)$

$\begin{array}{llllll}3,951 & 3,497 & 2.5 \mathrm{E} 3 & 11,166 & 65 & 11,231\end{array}$

Crime rate level, 04

(property

\& violent; categorical)

2.57

$2 \quad 1.05$

4

5

Hope VI neighborhood

(1=y, $0=n$ )

.01

0

.077

1

$0 \quad 1$


Percent nonwhite, vacant housing percent, rental percent, median housing age, unemployment, and population density are drawn from 2000 Census data. Crime rate for property and violent crime for 2004 is provided by the Louisville Metro Police Department by police district using 2000 population counts. The year 2005 is used because it is the first year data was available after the consolidation of Louisville and Jefferson County governments in 2003 . Table 7.3 on the previous page shows the summary descriptive statistics and variable measurement.

I added the HOPE VI neighborhood as a key policy intervention variable. This variable is set up as a dummy variable for the single case representing the HOPE VI project in Park DuValle. I run a regression analysis to hold other variables constant. This controls for the interventions that distinguishes the Park DuValle HOPE VI neighborhood from others, and provided the coefficient that measures the impact of HOPE VI. Also, controlling for policy interventions such as HOPE VI at the neighborhood level allows for better explanatory specification.

The direction, significance and effects of the traditional predictors are shown in Models 1 and 2. The amount of explained variation for median neighborhood housing values in Models 1 and 2 is near ninety percent. When we introduce HOPE VI in Model 2, HOPE VI exerts a positive influence, and contributes approximately $\$ 40,000$ in neighborhood property value in the HOPE VI neighborhood with a small and positive beta correlation. 
Table 7.4

Comparison of OLS Regression Results with Three Dependent Variables: Median Housing Value, Dollar Change, and Percent Change

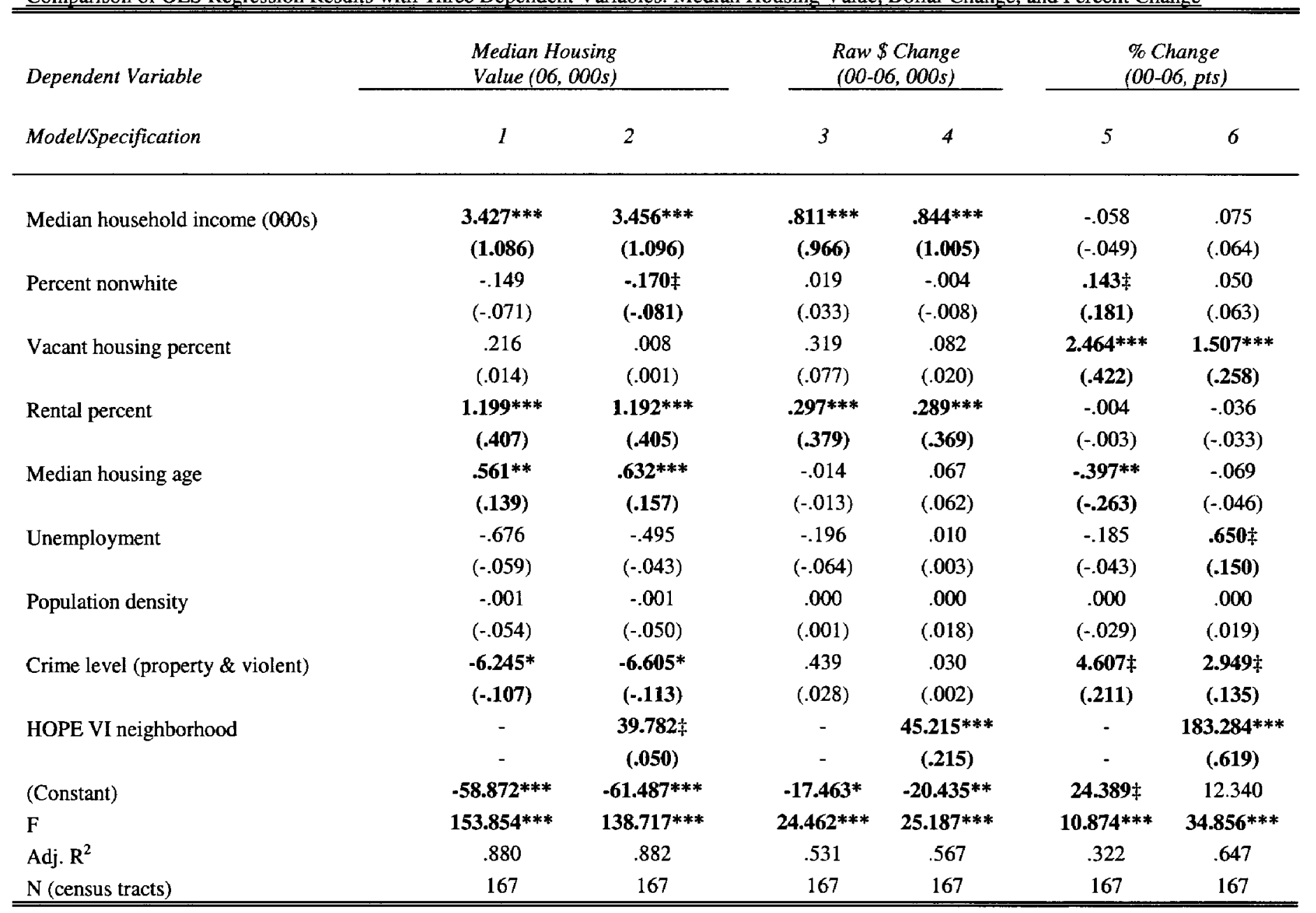

Unstandardized coefficients (standardized)

Sig: ***<.001**<.01*<.05 $\ddagger<.10$ level (significant predictors in bold)

Models were tested for multicollinearity with all tolerance scores exceeding .248 
When we measure the impact of HOPE VI using raw dollar change in Models 3 and 4 , the other intervening variables remain the same, with median housing age and crime rate no longer significant, but the amount of explained variation decreases by approximately one-third. As far as the unstandardized coefficient, the HOPE VI neighborhood experienced an approximately $\$ 45,000$ increase in property value above all other 169 neighborhoods in Louisville, and the second highest standardized beta for raw dollar increases in a positive direction.

In Model 5, without the HOPE VI policy intervention, the amount of explained variation is about one-third, while median household income and rental percentage, which were positive and significant in Models 1-4, were negative and no longer significant. When HOPE VI is introduced in Model 6, the amount of explained variation doubles to approximately two-third and has the highest beta levels for percentage change. When comparing the two measurements in predicting contemporary housing changes, either using raw dollar changes or percentage change, Model 6 is the best predictor and explains almost two-thirds of the variation.

Our analysis has shown that HOPE VI is a consistently positive and significant predictor in measuring changes in neighborhood housing dynamics, and the traditional predictor of median household income is diminished when predicting percentage change. The HOPE VI neighborhood in Park DuValle has significantly increased property values and has the highest increase in neighborhood property values among all 170 neighborhoods in Louisville from 2000 to 2006. Measuring the impact of HOPE VI as a policy intervention using percentage change captures the impact greater than median housing value or raw dollar change. 
The next chapter will provide conclusions on the analysis of the HOPE VI program in Newport, including implications for public policy on the impact of federal intervention programs like HOPE VI on the overall health and sustainability of the city, as well as explore future research questions on HOPE VI. 


\section{CHAPTER VIII}

\section{POLICY IMPLICATIONS AND CONCLUSIONS}

While the federal government intervention of the HOPE VI program is not the only reason for Newport's resurgence from "vice" to "nice," it has nonetheless played a major part in this story. The $\$ 28$ million investment the federal government made in Newport HOPE VI has been accompanied by an approximately one billion dollar investment over the next 10-15 years on the riverfront and more investment in Newport's downtown and Central Business District. According to Campbell County Judge Executive Steve Pendrey, $\$ 30$ million coming into Northern Kentucky is big money.... HOPE VI was the stimulus for this revival."

This dissertation investigates whether the existence of the HOPE VI program contributed to improving the quality of life and the economic revitalization of the city of Newport, which I proposed four hypotheses.

The first hypothesis tests whether HOPE VI has contributed to improving residential satisfaction and quality of life among the residents of the CSS program. An overwhelming majority of residents felt satisfied with where they live and have taken pride in their communities. An overwhelming majority of these residents know their neighbors, satisfied with relocating to a safer neighborhood, and satisfied with the recreational and entertainment opportunities for both children and adults within walking distance of where they live. They are satisfied with the programs and services offered by Brighton Center CSS and the Housing Authority of Newport, including childcare 
services, classes for employment and homeownership training, and educational opportunities. Participants surveyed also agree with the greater presence of safe and affordable housing, such as more Section 8 , less of a Section 8 waiting list, and more market rate housing available.

The residents surveyed believe that their neighborhood is safe and clean and the housing is well-maintained and that their neighborhood is diverse. Residents feel safe to walk or bike to school or work. They feel safer because of the adequate presence of street lighting. They believe that the police presence in their neighborhood has reduced crime and gun violence. Many parents surveyed agree that they feel comfortable allowing their children to play outside with other children in the community. Residents feel that there is accessibility for the disabled and elderly and are afforded many options for transportation. An overwhelming majority of residents surveyed noted that the programs offered by Brighton Center's CSS have improved their quality of life.

Regarding the second hypothesis, I conclude that the Community and Supportive Services (CSS) program offered by Brighton Center, Inc., and the Housing Authority of Newport (HAN) has provided greater self-sufficiency to the participants of the program. The residents overwhelmingly agree that they have more educational and employment opportunities. They have received the necessary job skills and training to be employable, such as resume and interview skills. They have been provided opportunities to take classes to earn a GED, participate in credit and debt counseling, and homeownership training. The skills taught by Brighton Center and HAN have enabled residents to be more self-sufficient, eventually own their own home, and become productive and contributing members of their community. 
With respect to the third hypothesis, this dissertation states that property values in neighborhoods that had the HOPE VI intervention (Saratoga Street and Liberty Row) increased between 94 and 520 percent, but one neighborhood without the HOPE VI intervention, East Row Historic District, increased by 136 percent, 42 percent higher than the Liberty Row HOPE VI neighborhood. This anomaly could be explained by the higher quality of life and architectural integrity of the historic designated districts versus non-designated neighborhoods, including HOPE VI, which could have an effect on higher property values in these areas, and the increase desire for people to want to live in older housing (Gilderbloom, House, and Hanka, 2008). The non-HOPE VI neighborhood, Southwest Downtown, experienced a 75 percent increase in property values, but was less than the increases experienced in both HOPE VI neighborhoods.

Because we were limited in performing a regression analysis because of a small sample and did not have the proper control variables, I accessed comparative data of changes in property values with the rest of the Newport, Covington, Cincinnati and the Cincinnati metropolitan area, and observed an approximately 21 percent total increase in property values over the entire region.

Also, the city of Newport is engaged in a $\$ 1$ billion investment on the old north site of Newport Housing Authority public housing called Ovation. Ovation will offer first class and mixed use development, such as retail, office, condominiums, a hotel and additional entertainment, lodging, and recreational amenities that are in closer proximity to downtown Newport.

My fourth hypothesis tests whether the presence of scattered-site developments in Newport's HOPE VI program indicates success compared to the Louisville Park DuValle 
HOPE VI program. The Park DuValle neighborhood has only one white individual living there and only one viable business in the neighborhood. Park DuValle faces many challenges as a neighborhood, such as its lack of walkability and isolation from the rest of the city and adjacent neighborhoods and the neighborhood's limited access to public transportation and other amenities.

Newport, on the other hand, placed new residents in new scattered-site HOPE VI developments in Liberty Row and Saratoga Street that are within walking distance of downtown businesses, shops, stores, restaurants, Newport on the Levee, and downtown Cincinnati, as shown in Appendix D. HOPE VI integrated into the Liberty Row neighborhood, which represents approximately 22 percent of the total number of properties in the neighborhood, and the Saratoga Street HOPE VI neighborhood, which represents nine percent of the total properties in the neighborhood. These HOPE VI developments are contributing to the increase in property values in these HOPE VI neighborhoods, the non-HOPE VI neighborhoods in our comparison, (East Row Historic District and Southwest Downtown) the rest of Newport, and the Cincinnati metropolitan area.

This dissertation has shown successes in terms of HOPE VI's impact. As with crime and business, this dissertation shows a definitive contribution, not done in a vacuum, from a tough, streetwise, smart, aggressive mayor- former Mayor Thomas Guidugli. The former mayor, who recently finished serving 16 years as Mayor and was elected to a seat on the Newport City Commission, was aggressive in seeking federal grants like HOPE VI and other economic development opportunities such as the Ovation project on the old public housing site. The consistent and steady leadership of former 
Mayor Guidugli enabled him and his staff to stay focused on the goal to implement a common sense strategy for revitalizing Newport. Newport's 180 degree turn, from its sordid organized crime past of vice and prostitution, into a city of renewal and revitalization, has turned this small river city into a premier destination for tourists, residents, businesses, and homeowners in the region.

In my opinion, the findings of this dissertation infer that the HOPE VI program in Newport has contributed to promoting sustainability by encouraging living in the downtown and central city, and encouraging the reuse and rehabilitation of older historic buildings and homes, as shown by the Newport model. The HOPE VI program in Newport fulfills a main objective of HOPE VI by integrating neighborhoods into mixedincome communities. HOPE VI homes also promotes energy efficiency through the rehabilitation of older homes and the construction of energy efficient homes that provide residents with low monthly utility bills, a departure from the $\$ 400$ per month energy bills paid by the residents in the old public housings site.

Unlike previous HOPE VI studies in other cities, the Newport HOPE VI project did not reinforce patterns of segregation and concentrated poverty, instead using the scattered site development approach, which increased property values in the HOPE VI and non-HOPE VI neighborhoods in Newport and the surrounding cities in the region.

An effective component of the Newport HOPE VI project was the Community and Support Services (CSS) program conducted by a local non-profit organization, Brighton Center, Inc., which proved to be a successful program. Newport's HOPE VI was criticized for removing more public housing than it replaced. However, the HOPE VI program in Newport fulfilled its main objectives of reducing the concentration of 
poverty, revitalizing distressed communities, removing the old physical structure of the housing, providing support services to residents, promoting personal and community responsibility and developing public and private partnerships.

Despite 16 years of successes and failures, and six billion dollars in total investment and another $\$ 11$ billion leveraged from the private and non-profit sector, the recent George W. Bush administration has slashed and eliminated funding for HOPE VI. The elimination of HOPE VI makes this dissertation timely and important in documenting the impact of a federal program like HOPE VI on a small sized city. An increased commitment by the current Obama administration and increased funding for HOPE VI is necessary and vital to ensure that the federal government's housing strategy of homeownership is the best way to ensure livable and sustainable communities and revitalize distressed communities throughout the United States.

This dissertation sheds new light on the importance of federal housing programs. Despite billions of federal dollars spent on HOPE VI over the last 16 years, little research has been done on the effectiveness of the HOPE VI program because of it relative newness. Further studies and research should be undertaken to analyze the impact of federal government intervention programs like HOPE VI or more medium and small size cities. Whether a Chicago or Akron, New York or Newport, or Los Angeles or Lincoln, small, medium and large cities are guided by the growth machine and must pursue developmental policies to establish their bargaining position in the marketplace (Logan \& Molotch, 1987). If resources are available, studies should be done to conduct a comparison across metropolitan areas analyzing the impact and effectiveness of HOPE VI, including controlling HOPE VI with other intervening factors. 
Newport's foresight and wherewithal to seek federal grants like HOPE VI provided the catalyst to turn around a city and become a major economic development player in the Cincinnati region. HOPE VI is enabling improvement and change in people's lives so they may eventually afford their own homes and become more responsible and productive citizens. 


\section{REFERENCES}

Abrams, Rhonda. (2006, October 16). Your chances of success. From: http://finance.yahoo.com/exper//article/entrepreneur/10954

Ambrosius, J., Beacom, A., Boice, C., Brannen, S., Brown, S., Castells, N., et al. (2006). Neighborhoods left behind in Baltimore's housing boom: Occasional paper no. 30. Baltimore: The Johns Hopkins University Institute for Policy Studies.

Ambrosius, Joshua D., Gilderbloom, John I., \& Hanka, Matthew J. (2009). Back to Black ... and Green? Contemporary housing dynamics in a medium-sized U.S. city. Accepted for revise and resubmit to Housing Policy Debate.

Archer, W. R., Gatzlaff, D. H., \& Ling, D. C. (1996). Measuring the importance of location in house price appreciation. Journal of Urban Economics, 40, 334-353.

Babbie, Earl. (2004). The practice of social research $\left(10^{\text {th }}\right.$ ed.). Belmont, CA: Wadsworth/Thomson Learning.

Barker, Thomas \& Gary W. Potter and Jenna Meglen. (2008). Wicked NewportKentucky's Sin City. Charleston, SC: The History Press.

Basu, K., \& Emerson, P. (2003). Efficiency pricing, tenancy rent control and monopolistic Landlords. Economica, 70(278), 223-232.

Bogart, William. (1998). The economics of cities and suburbs. Upper Saddle River, NJ: Prentice Hall.

Brazley, Michael. (2002). An evaluation of residential satisfaction of HOPE VI: A study of the Park DuValle revitalization project. Doctoral dissertation, University of Louisville, Louisville, KY.

Brazley, Michael E., \& Gilderbloom, John I. (2007). HOPE VI housing program-Was it effective? American Journal of Economics and Sociology, 66(2), 433-442.

Briggs, Xavier de Souza (Ed.). (2005). The geography of opportunity-Race and housing choice in metropolitan America. Washington, DC: Brookings Institution. 
Burby, Raymond J., \& Rohe, William M. (1989). Deconcentration of public housing: Effects on residents' satisfaction with their living environments and their fear of crime. Urban Affairs Quarterly, 25(1), 117-141.

Calhoun, Craig J. (1994). Social theory and the politics of identity. Cambridge, MA: Blackwell Publishing, Inc.

Campbell, Donald \& Stanley, Julian C. (1963). Experimental and quasiexperimental designs for research. Boston: Houghton Mifflin Company.

Case, K. E., \& Mayer, C. J. (1996). Housing price dynamics within a metropolitan area. Regional Science and Urban Economics, 26, 387-407.

Casebolt, Pamela Ciafardini, \& Ciafardini, Philip G. (2007) Images of America, Italians of Newport and Northern Kentucky. San Francisco: Arcadia Publishing.

Chicago Housing Authority, Chicago, IL. (n.d.). The CHA plan for transformation. Retrieved from: http://www.thecha.org/transformaplan/plan summary.html

Clark, Terry, Lloyd, Richard, Wong, Kenneth K., \& Jain, Pushpam. (2002). Amenities drive urban growth. Journal of Urban Affairs, 24(5): 493-515.

Clift, Kenneth M., Daniels, Betty Maddox, Fennell, Elisabeth Pursser, \& Whitehead, Michael E. (1995). Newport, Kentucky: A Bicentennial History (Thomas L. Purvis, Ed.). Newport, KY: Otto Zimmerman and Son, Inc.

Corporex, Inc. (2006, November 6). Economic Impact Study for Ovation Development, Newport, Kentucky. Prepared for Kentucky Cabinet for Economic Development.

Corporex, Inc. (2007). Economic Impact Study for Ovation Development, Newport, Kentucky [Ovation Powerpoint Presentation].

Cunningham, L. E. (2001). Islands of affordability in a sea of gentrification: Lessons learned from the DC Housing Authority's HOPE VI projects. Journal of Affordable Housing and Community Development Law, 10(4), 353-371.

Cunningham, Mary K., Popkin, Susan J., \& Burt, Martha R. (2005, June). Public housing transformation and the "Hard to house." (Brief No. 9). Washington, DC: The Urban Institute.

DeMichele, Matthew, \& Potter, Gary. (2009). Sin city revisited: A case study of the official sanctioning of organized crime in an "open city." Richmond, KY: Eastern Kentucky University. From: www.rootsweb.com/ kycampbe/newportgambling.htm 
Dreier, Peter, Mollenkopf, John, \& Swanstrom, Todd. (2001). Place matters: Metropolitics for the twenty-first century. Lawrence, KS: University Press of Kansas.

Durkheim, Emile. (1982). The rules of sociological method and selected texts on sociology and its method. New York, NY: The Free Press.

East Row Historic District. (2008). The history of Newport, Kentucky and the East Row. From: www.eastrow.org/history.html

Eisinger, Peter. (2000). The politics of bread and circuses: Building the city for the visitor class. Urban Affairs Review, 35(3), 316-333.

Eversley, Melanie. (2006, December 21). Cities changing one-way streets back. USA Today.

Fasig, Lisa Biank. (2008, January 11). Levee Gets glory, but Monmouth the Historic gem. Cincinnati Business Courier.

Feagin, Joseph R., Orum, Anthony M., \& Gideon Sjoberg (Eds.). (1991). A Case for the case study. Chapel Hill, NC: University Press of North Carolina.

Florida, Richard. (2002). The rise of the creative class. New York: Basic Books.

Florida, Richard. (2005). Cities and the creative class. New York: Routledge.

Friedman, Milton, \& Stigler, George J. (1946). Roofs or ceilings? The current housing problem. From the Foundation for Economic Education Freedom Library website, http://www.fee.org/library/books/Roofs or Ceilings.asp

Galster, George C. (1987). Homeowners and neighborhood investment. Durham, NC: Duke University Press.

Galster, George C., \& Killen, Sean P. (1995). The geography of metropolitan opportunity: A reconnaissance and conceptual framework. Housing Policy Debate, 6(1), 7-43.

Galster, George C., \& Mikelsons, Maris. (1995). The geography of metropolitan opportunity: A case study of neighborhood conditions confronting youth in Washington, DC. Housing Policy Debate, 6(1), 73-104.

Gilderbloom, John I. (2008). Invisible city: Poverty, housing, and new urbanism. Austin, Texas: University of Texas Press. 
Gilderbloom, John I. (2004). Newport's HOPE VI project evaluation. Volume V. Louisville, KY: University of Louisville, Center for Sustainable Urban Neighborhoods.

Gilderbloom, John I., \& Appelbaum, Richard. (1988). Rethinking rental housing. Philadelphia: Temple University Press.

Gilderbloom, John I., \& Brazley, Michael. (2003). Newport's HOPE VI project evaluation. Volume II. Louisville, KY: University of Louisville, Center for Sustainable Urban Neighborhoods.

Gilderbloom, John I., Brazley, Michael, Alam, Margaret Alexander, Ashan, Mohammed, \& Ramsey, Scot. (2002). Newport's HOPE VI project baseline evaluation: Volume 1. Louisville, KY: University of Louisville, Center for Sustainable Urban Neighborhoods.

Gilderbloom, John I., \& Hanka. Matt. (2007, June 13). Louisville's "new urbanism." The Courier-Journal, Louisville, KY, A11.

Gilderbloom, John I., \& Hanka, Matthew J. (2006). Newport's HOPE VI project evaluation: Volume IX. Louisville, KY: University of Louisville, Center for Sustainable Urban Neighborhoods.

Gilderbloom, John I., Hanka, Matthew J., \& Lasley, Carrie Beth. (2009). Amsterdam: The ideal city, policy and planning. Local Environment, The International Journal of Justice and Sustainability 14 (6), 473-492.

Gilderbloom, John I., Ye, Lin, Hanka, Matthew J., \& Usher, Kareem. (2009). Inter-city rent differentials in the U.S. housing market 2000: Understanding rent variations as a sociological phenomenon. Accepted in Journal of Urban Affairs, 31 .

Gilderbloom, John I., \& Hanka, Matthew J. and Ambrosius, Joshua D. (2009). The impact of historic preservation on jobs, property values, and environmentalism. Manuscript accepted for revision and resubmission to Journal of Urbanism

Gilderbloom. John I., Hanka, Matthew J., \& House, Erin. (2008). Historic preservation in Kentucky. Hodgenville, KY: Preservation Kentucky, Inc.

Gilderbloom, John I., Hanka, Matthew J., \& Lasley, Carrie Beth. (2008). Newport's HOPE VI project evaluation: Final Volume. Louisville, KY: University of Louisville, Center for Sustainable Urban Neighborhoods.

Gilderbloom, John I., Ambrosius, Joshua D., \& Hanka, Matthew J. (2008). Capturing Contemporary Housing Dynamics: Neighborhood Value Versus Change. Unpublished Manuscript. 
Gilderbloom, John I., \& Mullins, R. L., Jr. (2005). Promise and betrayal: Universities and the battle for sustainable urban neighborhoods. Albany, NY: State University of New York Press.

Gilderbloom, John I., \& Roosa, Stephen A. (2004). Newport's HOPE VI project evaluation. Volume IV. Louisville, KY: University of Louisville, Center for Sustainable Urban Neighborhoods.

Go 2 Newport. (2008). The place to go for what you love to do. Retrieved from:http://go2newport.com/joomla/index.php

Goldfarb, Ronald. (1995). Perfect villains, imperfect heroes. Robert F. Kennedy's war against organized crime. New York: Random House.

Green, Gary Paul. (2001). Amenities and community economic developmentStrategies for sustainability. Journal of Regional Analysis and Policy, 31(2), 6175.

Green, Marcus. (2007, June 5). Urban areas see biggest gains in property value. The Courier-Journal, Louisville, KY, A1.

Goetz, Edward G. (2000). The effects of subsidized housing on communities. Just in Time Research: Resilient Communities. Minneapolis, MN: Hubert H. Humphrey Institute of Public Affairs/University of Minnesota Extension Service.

Gotham, Kevin Fox. (2003). Toward an understanding of the spatiality of urban poverty: The urban poor as spatial actors. International Journal of Urban and Regional Research, 24(3), 723-737.

Harloe, M. (1985). Landlord/tenant relations in Europe and America-The limits and functions of the legal framework. Urban Law and Policy (7), 359-383.

Hanka, Matt, \& Gilderbloom, John. (2008, February 1). Time to end one-way thinking. The Courier-Journal, Louisville, KY.

Hayden, Dolores. (2002). Redesigning the American dream: Gender, housing, and family life. New York: W. W. Norton Co.

Housing Authority of Newport (HAN). (2000). 2000 HOPE VI Application. Newport, KY: HAN.

Housing Authority of Newport (HAN). (2007). Update on HOPE VI Program, June 1, 2007. Newport, KY: HAN. 
Imbroscio, David. (2004). Fighting poverty with mobility: A normative policy analysis. Review of Policy Research, 21(3), 447-461.

Imbroscio, David. (2008). "[U]nited and actuated by some common impulse of passion": Challenging the dispersal consensus in American housing policy research. Journal of Urban Affairs, 30(2), 111-130.

Jacobs, Jane. (1961). The death of and life of great American cities. New York: Random House.

John, Cathie. (2004). Publisher Notes. From: http://www.cathiejohn.com/jp2.html

Kantor, Paul. (1995). The dependent city revisited. The political economy of urban development and social policy. Boulder, CO: Westview Press.

Kantor, Paul, \& Savitch, H. V. (2005). How to study comparative urban development politics: A research note. International Journal of Urban and Regional Research, $29(1), 135-151$.

Kaufman, Julie E., \& Rosenbaum, James. (1992). The education and employment of low-income black youth in white suburbs. Educational Evaluation \& Policy Analysis, 14(3), 229-240.

Kelling, George . \& Catherine M. Coles. (1996). Fixing broken windows: Restoring Order and reducing crime in our communities. New York: Simon and Schuster.

Kentucky State Data Center. (2007). Employment data in census profiles. http://ksdc.louisville.edu/1employment.htm

Kim, Sunwoong. (2000). Race and home price appreciation in urban neighborhoods: Evidence from Milwaukee, Wisconsin. The Review of Black Political Economy, 9-28.

Kingsley, G. Thomas, \& Corvington, Patrick A. (2000). Case management and selfsufficiency: The challenge for HOPE VI. Washington, DC: The Urban Institute.

Kingsley, G. Thomas, Johnson, Jennifer, \& Petit, Kathryn L. S. (2003). Patterns of section 8 relocation in the HOPE VI program. Journal of Urban Affairs, 25(4), $427-447$.

Kleinberg, Benjamin. (1995). Urban America in transformation: Perspectives on urban policy and development. 'Thousands Oaks, CA: SAGE Publications.

Kleit, R. G., \& Rohe, William M. (2005). Using public housing to achieve selfsufficiency: Can we predict success? Housing Studies, 20(1), 81-105. 
Kruger, James S., \& Lewis-Beck, Michael S. (2008). Is OLS Dead? The Political Methodologist, 15 (2), 2-4.

Lees, Loretta, Slater, Tom, \& Wyly, Elvin. (2008). Gentrification. New York: Routledge.

Levy, Diane K. and Woolley, Mark. (2007). Relocation is not enough: Employment barriers among HOPE VI families. Washington, DC: The Urban Institute

Li, Y., \& Rosenblatt, E. (1997). Can urban indicators predict home price appreciation? Implications for redlining research. Real Estate Economics, 25, 81-104.

Logan, John, \& Molotch, Harvey. (1987). Urban Fortunes: the Political Economy of Place. Berkeley, CA: University of California Press.

Marcus, Clare Cooper. (2006). House as a mirror of self: Exploring the deeper meaning of home. Berwick, ME: Nicolas-Hays, Inc.

Marcuse, Peter. (2001). The liberal/conservative divide in the history of housing policy in the United States. Housing Studies, 16(6), 717-736.

Marcuse, Peter, \& Keating, W. Dennis. (2006). The permanent housing crisis: The failures of conservatism and the limitations of liberalism. In Rachel G. Bratt, Michael E. Stone, \& Chester W. Hartman (Eds.), A right to housing: Foundation for a new social agenda. Philadelphia: Temple University Press.

Massey, Douglas S., \& Denton, Nancy A. (1993). American apartheid: Segregation and the making of the underclass. Cambridge, MA: Harvard University Press.

Mattera, Phillip, \& Purinton, Anna. (2004). Shopping for subsidies: How Wal-Mart uses taxpayer money to finance its never-ending growth. Washington, DC: Good Jobs First, Inc.

Molotch, Harvey. (1976). City as a growth machine. Journal of the American Sociological Association, 82(2), 309-330.

Musterd, Sako, \& Salet, Willem (Eds.). (2003). Amsterdam human capital. Amsterdam: Amsterdam University Press.

National Historic Register of Places. (2009). National historic register of places fundamentals. Washington, DC. National Parks Service. U.S. Department of the Interior. From: http://www.nps.gov/nr/national register fundamentals.htm

Neff, Judy L., \& Harris, Peggy Wiedemann. (2004). Images of America-Newport. San Francisco: Arcadia Publishing. 
Newman, Oscar. (1973). Defensible space. New York: Collier Books.

Peterson, Paul. (1981). City limits. Chicago, IL: University of Chicago Press.

Plotkin, Wendy. (2001, Spring). "Hemmed in:" The struggle against racial restrictive covenants and deed restrictions in Post-WWII Chicago. Journal of the Illinois State Historical Society, 1-18.

Popkin, Susan. (2002). The HOPE VI program-What about the residents?" Washington, DC: The Urban Institute.

Popkin, Susan J., Buron, Larry F., Levy, Diane K., \& Cunningham, Mary K. (2000). The Gautreaux legacy: What might mixed income and dispersal strategies mean for the poorest public housing tenants. Housing Policy Debate, 11(4), 911-942.

Popkin, Susan J., \& Cunningham, Mary K. (1999). CHAC, Inc. section 8 program: Barriers to successful leasing up. Washington, DC: Urban Institute.

Popkin, Susan J., \& Cunningham, Mary K. (2000). Searching for rental housing with Section 8 in Chicago. Washington, DC: Urban Institute.

Popkin, Susan J., \& Cunningham , Mary K. (2005). Beyond the projects: Lessons from public hosing transformation. In Xavier de Souza Briggs (Ed.), Chicago in the geography of opportunity, race and housing choice in metropolitan America (pp. 176-196).

Popkin, Susan J., Katz, Bruce, Cunningham, Mary K., Brown, Karen D., Gustafson, Jeremy, \& Turner, Margery. (2004). A decade of HOPE VI; Research findings and policy challenges. Washington, DC: The Urban Institute and The Brookings Institution.

Popkin, Susan, Levy, Diane, Harris, Laura, Comey, Jennifer, Cunningham, Mary, \& Buron, Larry. (2004). The HOPE VI program: What about the residents? Housing Policy Debate, 15(2), 385-414.

Popkin, Susan J., Theodos, Brett, Roman, Caerina, Guernsey, Elizabeth, \& Getsigner, Liza. (2008). The Chicago family case management demonstration: Developing a new model for serving "hard to house" public housing families. Washington, DC: The Urban Institute.

Putnam, Robert. (2000). Bowling alone: The collapse and revival of American community. New York: Simon and Schuster Co.

Reid, Carolina Katz. (2007). Locating the American dream-Assessing the neighborhood benefits of homeownership. In William M. Rohe \& Harry L. 
Watson (Eds.), Chasing the American Dream: New Perspectives on Affordable Homeownership (pp. 233-277). Ithaca, NY: Comell University Press.

Rohe, William, \& Kleit, Rachel. (1997). From dependency to self-sufficiency: An appraisal of the gateway transitional families program. Housing Policy Debate, 7: 75-108.

Rohe, William, \& Stegman, Michael. (1994). The effects of homeownership on the selfesteem, perceived control, and life satisfaction of low-income people. Journal of the American Planning Association, 60(2), 163.

Rohe, William M., Van Zandt, Shannon, \& McCarthy, George. (2001). The Social Benefits and Costs of Homeownership: A Critical Assessment of the Research (Working Paper LIHO-01.12). Cambridge, MA: Joint Center for Housing Studies, Harvard University.

Rohe, William M., \& Watson, Harry L. (Eds.). (2007). Chasing the American dream: New perspectives on affordable homeownership. Ithaca, NY: Cornell University Press.

Rosenbaum, James E. (1991). Black pioneers: Do their moves to the suburbs increase economic opportunity for mothers and children? Housing Policy Debate 2(4), 1179-1214.

Rosenbaum, James E. (1995). Changing the geography of opportunity by expanding residential choice: Lessons from the Gautreaux program." Housing Policy Debate, 6(1), 231-269.

Rosenbaum, James E., Popkin, Susan J., Kaufman, Julie E., \& Rusin, Jennifer. (1991). Social Integration of Low-Income Black Adults in Middle-Class White Suburbs. Social Problems, 38(4), 448-461.

Rosin, Hannah. (2008, July). American Murder Mystery. The Atlantic Monthly.

Rossi, Peter H., Freeman, Howard, \& Lipsey, M. W. (1999). Evaluation- A systematic approach ( $6^{\text {th }}$ ed.). Thousands Oaks, CA: Sage Publications, Inc.

Rubinowitz, Leonard, \& Rosenbaum, James E. (2000). Crossing the class and color lines: Low-income black families in white suburbs. Chicago: University of Chicago Press.

Rypkema, Donovan D. (1994). The Economics of Historic Preservation: A Community Leaders' Guide. Washington, DC: National Trust for Historic Preservation, 
Rypkema, Donovan D. (2006, September 19). Smart Growth, Sustainable Development and Historic Preservation. Presentation at the Bridging Boundaries-Building Great Communities Regional Smart Growth Conference, Louisville, KY.

Ryzin, Gregg Van, Ronda, Michelle, \& Muzzio, Douglas. (2001). Factors related to self-sufficiency in a distressed public housing community. Journal of Urban Affairs, 23(1), 57-69.

Salama, Jerry J. (1999). The redevelopment of distressed public housing: Early results from HOPE VI projects in Atlanta, Chicago, and San Antonio. Housing Policy Debate, 10(1), 95-142.

Savitch, H.V., \& Kantor, Paul. (2002). Cities in the international marketplace. Princeton, NJ: Princeton University Press.

Santiago, Anna M., \& Galster, George C. (2004). Moving from public housing to homeownership: Perceived barriers to program participation and success. Journal of Urban Affairs, 26(3), 297-324.

Schwartz, Alex F. (2006). Housing policy in the United States: An introduction. New York: Routledge Press.

Schutt, Russell K. (2004). Investigating the social world-The process and practice of research $\left(4^{\text {th }}\right.$ ed.). Thousands Oaks, CA: Pine Forge Press.

Subcommittee on Housing and Transportation, Committee on Banking, Housing, and Urban Affairs, U.S. Senate (2002). Public housing: HOPE VI leveraging has increased, but HUD has not met annual reporting requirement (GAO Publication No. GAO-03-91). Washington, DC: General Accounting Office.

Sylvia, Ronald D., Sylvia, Kathleen M. \& Gunn, Elizabeth M. (1997). Program planning and evaluation for the public manager $\left(2^{\text {nd }}\right.$ ed.). Prospect Heights, IL: Waveland Press.

Tenkotte, P.A. (1989). Rival cities to suburbs: Covington and Newport, Kentucky, 1790 1890. Doctoral dissertation, University of Cincinnati, Cincinnati, $\mathrm{OH}$.

Thompson, Molly. (2006). Relocating from the distressed public housing on the difficulties of the private market: How the move threatens to push families away from opportunity. Joumal of Law and Social Policy, 1(1), 1-32.

Turner, Margery A., Woolley, Mark, Kingsley, G. Thomas, Popkin, Susan J., Levy, Diane, \& Cove, Elizabeth. (2007). Estimating the public costs and benefits of HOPE VI investments: A methodological report: Washington, DC: The Urban Institute. 
U.S. Bureau of the Census. (2000). Census of Population and Housing. Compiled by Eric Schneider, Kentucky State Data Center, University of Louisville, Louisville, KY.

U.S. Department of Housing and Urban Development. (1992). Final report of the National Commission on Severely Distressed Public Housing: A report to Congress and the Secretary of Housing and Urban Development. Washington, DC: HUD.

U.S. Department of Housing and Urban Development (HUD). (1999). HOPE VI: Building communities, transforming lives. Washington, DC: HUD.

U.S. Department of Housing and Urban Development (HUD). (2000). Community building makes a difference. Washington, DC: HUD.

U.S. Department of Housing and Urban Development. (2003). Updating the LowIncome Housing Tax Credit (LIHTC) Database Projects Placed in Service Through 2003. Washington, DC: HUD. Office of Economic Affairs.

Varady, David P., \& Preiser. Wolfgang F. (1998). Scattered-site public housing and housing satisfaction. Journal of the American Planning Association, 64(2), 189207.

Varady, David P., \& Walker, Carole C. (2003). Housing vouchers and residential mobility. Journal of Planning Literature, 18(1), 17-30.

Varady, David P, Walker, Carole C., \& Wang, Xinhao. (2001). Voucher recipient achievement of improved housing conditions in the US: Do moving distance and relocation services matter? Urban Studies, 38(8), 1273-1304.

Walker, Wade G., Kulash, Walter M., \& McHugh, Brian T. (2007). Downtown streets-Are we strangling ourselves on one-way networks? http://onlinepubs.trb.org/onlinepubs/circulars/ec019/Ec019 f2.pdf

Williams, Sabrina L. (2003, July/August). From HOPE VI to HOPE SICK? Dollars and Sense-The Magazine of Economic Justice.

Wilson, William Julius. (1987). The truly disadvantaged: The inner city, the underclass and public policy. Chicago: The University of Chicago Press.

Wyly, E., \& Hamel, D. (1999). Islands of decay in seas of renewal: Housing policy and the resurgence of gentrification. Housing Policy Debate, 10(4), 711-771.

Yoder, Robert. (2005). Newport in Vintage Postcards. San Francisco: Arcadia Publishing. 


\section{APPENDIX A SURVEY OF HOPE VI RESIDENTIAL SATISFACTION ${ }^{1}$}

\section{Dear HOPE VI Residents:}

This is one of our final surveys to gather information on your overall satisfaction of your neighborhood, community, and the services you received from Brighton Center's

Community and Supportive Services (CSS) and the Housing Authority of Newport (HAN) as it relates to the HOPE VI program. We want to hear from you to determine if you and your family have a better quality of life because of the HOPE VI program collectively. The information you provide will be useful in evaluating HOPE VI. Please take a few minutes to complete this survey. If you need help with filling out this survey, please contact us. Your answers will remain anonymous. Your opinions are important to our research and will remain confidential. Thank you for your time and participation.

\section{Sincerely,}

John I. Gilderbloom, Professor

\& Matt Hanka, Research Associate

University of Louisville, Center for Sustainable Urban Neighborhoods 502-852-8557

\footnotetext{
${ }^{1}$ Sponsored by the University of Louisville, Center for Sustainable Urban Neighborhoods (SUN) and Brighton Center, Inc., Newport, KY, June 2007.
} 


\section{Neighborhood Satisfaction}

Here are some statements about how residents may feel about their living situation in the HOPE VI program. Tell us to what extent do you agree or disagree with these statements. Please place a check mark in the box that corresponds to your answer. Select only one response.

\section{SA - Strongly Agree D- Disagree \\ A- Agree \\ N- Neutral (Neither \\ Agree nor Disagree) \\ SD- Strongly Disagree \\ NA- No Answer}

$\begin{array}{lcccccc} & \text { SA } & \text { A } & \text { N } & \text { D } & \text { SD } & \text { NA } \\ \text { I like living in my neighborhood } & \text { [ ] } & \text { [ ] } & \text { [ ] } & \text { [ ] } & \text { [ ] } & \text { [ ] } \\ \text { I know my neighbors } & \text { [ ] } & \text { [ ] } & \text { [ ] } & \text { [ ] } & \text { [ ] } & \text { [ ] }\end{array}$

I can walk or ride a bike to work easily and safely in my neighborhood

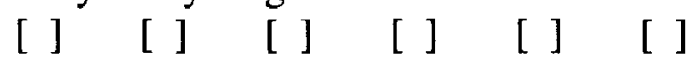

I can walk or ride a bike to the grocery store easily and safely in my neighborhood

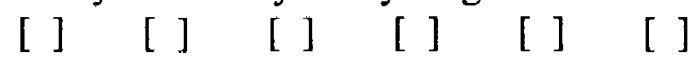

My (child) children can walk to school easily and safely in my neighborhood

[ ] [ ] [ [ ] [ ] $\left[\begin{array}{lll}\text { [ ] } & \text { [ }\end{array}\right.$

My family and I would benefit from bicycle safety education

[ ] [ ] [ ] [ ] [ ] [ ]

Compared to my neighborhood seven years ago (2000), there are more recreation activities available near my home for my children

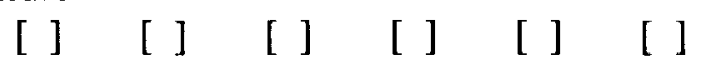

Compared to my neighborhood seven years ago (2000), there are recreation activities available near my home for adults

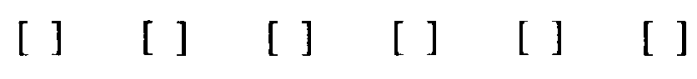

I have more choices for entertainment within walking distance of my neighborhood than my neighborhood seven years ago (2000)

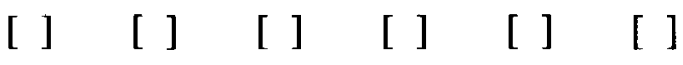


$\begin{array}{llllll}\text { SA } & A & \mathbf{N} & \mathbf{D} & \text { SD } & \text { NA }\end{array}$

I have more choices for employment in my neighborhood than I did seven years ago (2000)

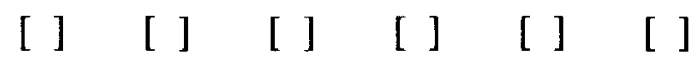

Housing Authority of Newport has made my situation worse

$$
\text { [ ] [ ] [ ] [ ] [ ] [ ] }
$$

Brighton Center's CSS program has made my situation worse

$$
\text { [ ] }\left[\begin{array}{lllll}
\text { [ ] } & {[\mathrm{l}} & {[\mathrm{l}} & \text { [ ] } & \text { [ ] }
\end{array}\right.
$$

I have better job opportunities because of Brighton Center's CSS program

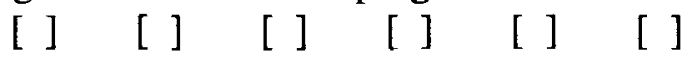

I have better job opportunities because of Housing Authority of Newport

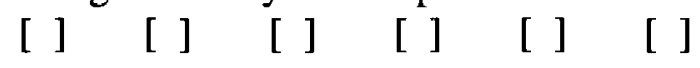

I have choices for transportation (ex. bus, biking, car pooling) in my neighborhood

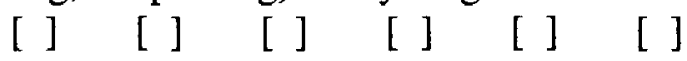

My family and I use bicycles or walk to and from school or work

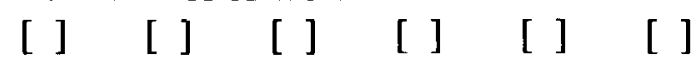

My neighborhood is accessible to people who are elderly or disabled

[ ] [ ] [ ] [ ] [ ] [ ]

I have better educational opportunities now because of the Housing Authority of Newport
[ ] [ ]
[
[ ] [ ] [ ]

I have better educational opportunities now because of Brighton Center's CSS

$$
\text { [ ] [ ] [ ] [ ] [ ] [ ] }
$$

Brighton Center's CSS is doing a good job

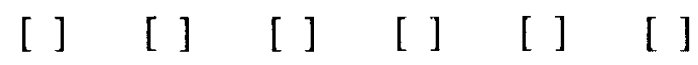

Housing Authority of Newport (HAN) is doing a good job

[ ] [ ] [ [ ] $\left[\begin{array}{llll}\text { ] ] } & \text { [ ] } & \text { [ ] }\end{array}\right.$

My life is better because of Brighton Center CSS.

[ ] $\left[\begin{array}{lllll}\text { [ ] } & {[\text { ] }} & \text { [ ] } & \text { [ ] } & \text { [ ] }\end{array}\right.$

My life is better because of the Housing Authority of Newport

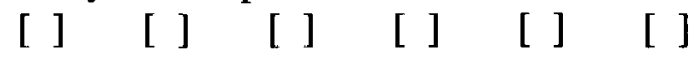


$\begin{array}{lllllllll} & \text { SA } & A & \text { N } & \text { D } & \text { SD } & \text { NA }\end{array}$

I wish to move out of my neighborhood in the future

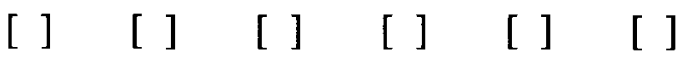

I wish to stay in the neighborhood and purchase my home

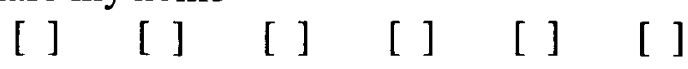

\section{Community Residents and Safety}

SA A N N D $\quad$ SD NA

There are people with different backgrounds, cultures or life experiences in my community

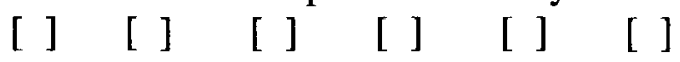

I relate well with my neighbors and community members

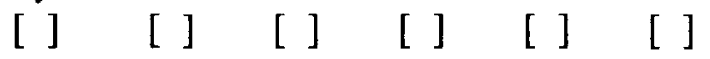

I feel safe in my neighborhood

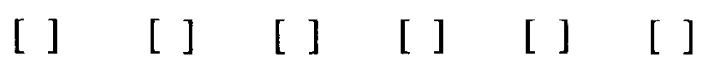

My children have close and safe places to play

$\left[\begin{array}{llllll}] & {[}\end{array}\right] \quad\left[\begin{array}{lll}] & {[} & {[}\end{array}\right]$

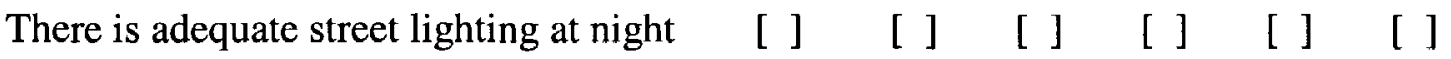

There is adequate police presence in the neighborhood

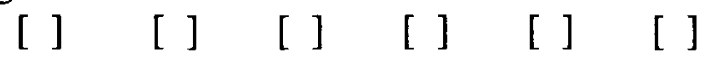

\section{Community Activity}

$\begin{array}{llllll}\text { SA } & \text { A } & \text { N } & \text { D } & \text { SD } & \text { NA }\end{array}$

I have attended events, festivals and meetings in my community

$\left[\begin{array}{llllll}] & {[}\end{array}\right]\left[\begin{array}{lll}] & {[} & {[}\end{array}\right]$

I am registered to vote

$\left[\begin{array}{llllll}] & {[}\end{array}\right] \quad\left[\begin{array}{lll}] & {[}\end{array}\right]$

I voted in the 2004 Presidential election

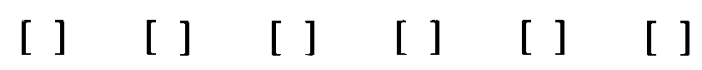

I am a member of a community organization or group

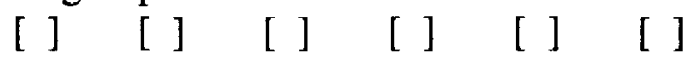

I take pride in the community where I live

[ ] [ [ ] [ [ ] $\left[\begin{array}{llll}\text { [ ] } & \text { [ ] } & \text { [ ] }\end{array}\right.$


IV. Safe and Affordable Housing

SA A $\quad$ N $\quad$ D $\quad$ SD NA

Housing on the south site of the Housing Authority is better now than it was seven years ago (2000)

My community is clean

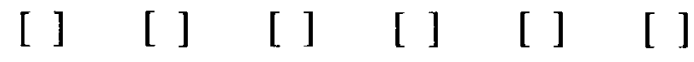

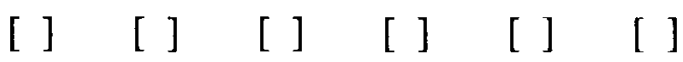

The houses and apartment buildings on my street are well maintained

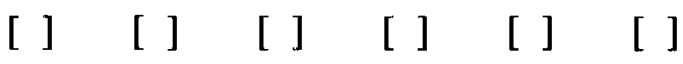

Graffiti has gotten worse since 2000

[ ] $\left[\begin{array}{lllll}{[} & {[} & {[}\end{array}\right]\left[\begin{array}{lll}\text { ] } & \text { [ ] } & \text { [ ] }\end{array}\right.$

There are more drugs in my neighborhood than there was in 2000

[ ] $\left[\begin{array}{lllll}\text { [ ] } & \text { [ ] } & \text { [ ] } & \text { [ ] } & \text { [ ] }\end{array}\right.$

There is more gun violence in my neighborhood than there was in 2000

[ ] [ ] [ [ ] $\left[\begin{array}{lll}\text { [ ] } & \text { [ ] } & \text { [ ] }\end{array}\right.$

There is more safe and affordable subsidized housing than there was in 2000

[ ] [ ] [ [ ] [ ] [ ] [ ]

There is more available Section 8 housing than there was in 2000

[ ] $\left[\begin{array}{lllll}\text { [ ] } & \text { [ ] } & \text { [ ] } & \text { [ ] } & \text { [ ] }\end{array}\right.$

There is a shorter Section 8 housing waiting list than there was in 2000

[ ] [ ] [ ] [ ] $\left[\begin{array}{lll}\text { ] } & \text { [ ] }\end{array}\right.$

There are more market-rate housing opportunities than there was in 2000

[ ] [ ] [ [ ] [ [ ] [ ] [ ]

I am more comfortable allowing my kids to play outside in the neighborhood than I was in 2000

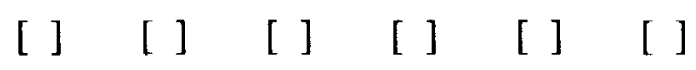

V. Here are some statements about the services provided by Brighton Center, Inc. Tell us to what extent do you agree or disagree with these statements. Please place a check mark in the box that corresponds to your answer. Select only one response.

Brighton Center's CSS has helped improve my job skills

$$
\begin{array}{llllll}
\text { SA } & \text { A } & \text { N } & \text { D } & \text { SD } & \text { NA }
\end{array}
$$

[ ] [ ] [ [ ] $\left[\begin{array}{llll}\text { [ ] } & \text { [ ] } & \text { [ ] }\end{array}\right.$


$\begin{array}{llllll}\text { SA } & \text { A } & \text { N } & \text { D } & \text { SD } & \text { NA }\end{array}$

Brighton Center's CSS has helped improve my educational skills

[ ] $\left[\begin{array}{lllll}1 & {[} & {[]} & {[]} & {[}\end{array}\right]$

Brighton Center's CSS has helped connect me to new employment opportunities

[ ] [ [ ] [ [ ] [ [ ] [ ] [ ]

Brighton Center's CSS has helped me become more employable by working with my resume and interview skills
[
] [ ] [
] [
$\left[\begin{array}{ll}{[} & {[}\end{array}\right.$

I have used Brighton Center's Bright Days Child development Center

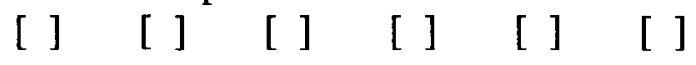

Brighton Center's CSS has educated me about childcare alternatives

[ ] [ ] [ ] [ ] $[$ [ ] [ ]

Brighton Center's CSS has provided programs for my children

[ ] [ ] [ ] $\left[\begin{array}{llll}\text { ] ] } & {[\text { ] }} & \text { [ ] }\end{array}\right.$

Brighton Center's CSS services have improved my family's quality of life.

[ ] $\left[\begin{array}{lllll}\text { [ ] } & {[\text { ] }} & \text { [ ] } & \text { [ ] } & \text { [ ] }\end{array}\right.$

VI. Demographic Information (We want to know a little about you)

What is your age?

What is your race?

What is your gender?

- Female

- Male

What is the highest level of education completed?

Number of Persons in Household (include yourself)

What is your employment status?
- Full Time
- Part Time
- Unemployed, looking for work
- Unemployed, not looking for work 
What is your estimated monthly household Income: $\$$ per month

Do you own a car?

$$
\begin{array}{ll}
- & \text { Yes } \\
\text { - No }
\end{array}
$$

Do you own a bicycle?

$$
\begin{array}{ll}
\text { - Yes } \\
\text { - No }
\end{array}
$$

What is your marital status?
- Single
- Married
- Separated/Divorced
- Divorced
- Widowed
- No response

Once again, thank you for participating in this survey. We are grateful for your input. If you have any other information you would like to share with us, please do so in the space provided below. 


\section{APPENDIX B}

\section{RESULTS OF HOPE VI RESIDENTIAL SATISFACTION SURVEY}

\begin{tabular}{|c|c|c|c|c|c|c|c|c|}
\hline \multicolumn{9}{|c|}{ Neighborhood Satisfaction } \\
\hline & $\begin{array}{l}\text { Strongly } \\
\text { Agree }\end{array}$ & Agree & Neutral & Disagree & $\begin{array}{l}\text { Strongly } \\
\text { Disagree }\end{array}$ & N/A & $\begin{array}{l}\text { Rating } \\
\text { Average }\end{array}$ & $\begin{array}{c}\text { Response } \\
\text { Count }\end{array}$ \\
\hline $\begin{array}{l}\text { I like living in } \\
\text { my } \\
\text { neighborhood }\end{array}$ & $31.5 \%(17)$ & $\begin{array}{c}38.9 \% \\
(21)\end{array}$ & $\begin{array}{c}13.0 \% \\
(7)\end{array}$ & $\begin{array}{c}13.0 \% \\
(7)\end{array}$ & $1.9 \%(1)$ & $\begin{array}{c}1.9 \% \\
(1)\end{array}$ & 2.13 & 54 \\
\hline $\begin{array}{l}\text { I know my } \\
\text { neighbors }\end{array}$ & $18.5 \%(10)$ & $\begin{array}{c}53.7 \% \\
(29)\end{array}$ & $\begin{array}{c}5.6 \% \\
(3)\end{array}$ & $\begin{array}{c}13.0 \% \\
(7)\end{array}$ & $9.3 \%(5)$ & $\begin{array}{c}0.0 \% \\
(0)\end{array}$ & 2.41 & 54 \\
\hline $\begin{array}{l}\text { I can walk or } \\
\text { ride a bike to } \\
\text { work easily and } \\
\text { safely in my } \\
\text { neighborhood }\end{array}$ & $20.4 \%(11)$ & $\begin{array}{c}46.3 \% \\
(25)\end{array}$ & $\begin{array}{c}1.9 \% \\
(1)\end{array}$ & $\begin{array}{c}13.0 \% \\
(7)\end{array}$ & $1.9 \%(1)$ & $\begin{array}{c}16.7 \% \\
(9)\end{array}$ & 2.16 & 54 \\
\hline $\begin{array}{l}\text { I can walk or } \\
\text { ride a bike to the } \\
\text { grocery store } \\
\text { easily and safely } \\
\text { in my } \\
\text { neighborhood }\end{array}$ & $20.4 \%(11)$ & $\begin{array}{c}42.6 \% \\
(23)\end{array}$ & $\begin{array}{c}0.0 \% \\
(0)\end{array}$ & $\begin{array}{c}16.7 \% \\
(9)\end{array}$ & $5.6 \%(3)$ & $\begin{array}{c}14.8 \% \\
(8)\end{array}$ & 2.35 & 54 \\
\hline $\begin{array}{l}\text { My (child) } \\
\text { children can } \\
\text { walk to school } \\
\text { easily and safely } \\
\text { in my } \\
\text { neighborhood }\end{array}$ & $22.2 \%(12)$ & $\begin{array}{c}33.3 \% \\
(\mathbf{1 8})\end{array}$ & $\begin{array}{c}7.4 \% \\
(4)\end{array}$ & $9.3 \%(5)$ & $0.0 \%(0)$ & $\begin{array}{c}27.8 \% \\
(15)\end{array}$ & 2.05 & 54 \\
\hline $\begin{array}{l}\text { My family and I } \\
\text { would benefit } \\
\text { from bicycle } \\
\text { safety education }\end{array}$ & $13.0 \%(7)$ & $\begin{array}{c}29.6 \% \\
(16)\end{array}$ & $\begin{array}{c}5.6 \% \\
(3)\end{array}$ & $5.6 \%(3)$ & $\begin{array}{c}11.1 \% \\
(6)\end{array}$ & $\begin{array}{c}35.2 \% \\
\text { (19) }\end{array}$ & 2.57 & 54 \\
\hline $\begin{array}{l}\text { Compared to my } \\
\text { neighborhood } \\
\text { seven years ago } \\
\text { ( } 2000) \text {, there are } \\
\text { more recreation } \\
\text { activities } \\
\text { available near } \\
\text { my home for my } \\
\text { children }\end{array}$ & $14.8 \%(8)$ & $\begin{array}{c}22.2 \% \\
(12)\end{array}$ & $\begin{array}{c}3.7 \% \\
(2)\end{array}$ & $9.3 \%(5)$ & $\begin{array}{c}20.4 \% \\
(11)\end{array}$ & $\begin{array}{c}29.6 \% \\
(16)\end{array}$ & 2.97 & 54 \\
\hline
\end{tabular}




\begin{tabular}{|c|c|c|c|c|c|c|c|c|}
\hline & $\begin{array}{l}\text { Strongly } \\
\text { Agree }\end{array}$ & Agree & Neutral & Disagree & $\begin{array}{l}\text { Strongly } \\
\text { Disagree }\end{array}$ & N/A & $\begin{array}{c}\text { Rating } \\
\text { Average }\end{array}$ & $\begin{array}{c}\text { Response } \\
\text { Count }\end{array}$ \\
\hline $\begin{array}{l}\text { Compared to my } \\
\text { neighborhood } \\
\text { seven years ago } \\
(2000) \text {, there are } \\
\text { recreation } \\
\text { activities } \\
\text { available near } \\
\text { my home for } \\
\text { aduits }\end{array}$ & $13.0 \%(7)$ & $\begin{array}{c}29.6 \% \\
(16)\end{array}$ & $\begin{array}{c}5.6 \% \\
(3)\end{array}$ & $\begin{array}{c}20.4 \% \\
(11)\end{array}$ & $\begin{array}{c}20.4 \% \\
(11)\end{array}$ & $\begin{array}{c}11.1 \% \\
(6)\end{array}$ & 3.06 & 54 \\
\hline $\begin{array}{l}\text { I have more } \\
\text { choices for } \\
\text { entertainment } \\
\text { within walking } \\
\text { distance of my } \\
\text { neighborhood } \\
\text { than my } \\
\text { neighborhood } \\
\text { seven years ago } \\
(2000)\end{array}$ & $15.1 \%(8)$ & $\begin{array}{c}\mathbf{3 5 . 8 \%} \\
\text { (19) }\end{array}$ & $\begin{array}{c}9.4 \% \\
\text { (5) }\end{array}$ & $\begin{array}{c}15.1 \% \\
(8)\end{array}$ & $\begin{array}{c}15.1 \% \\
(8)\end{array}$ & $\begin{array}{l}9.4 \% \\
(5)\end{array}$ & 2.77 & 53 \\
\hline $\begin{array}{l}\text { I have more } \\
\text { choices for } \\
\text { employment in } \\
\text { my } \\
\text { neighborhood } \\
\text { than I did seven } \\
\text { years ago }(2000)\end{array}$ & $11.1 \%(6)$ & $\begin{array}{c}20.4 \% \\
(11)\end{array}$ & $\begin{array}{c}13.0 \% \\
(7)\end{array}$ & $\begin{array}{c}22.2 \% \\
(12)\end{array}$ & $\begin{array}{c}14.8 \% \\
(8) \\
\vdots\end{array}$ & $\begin{array}{c}18.5 \% \\
(10)\end{array}$ & 3.11 & 54 \\
\hline $\begin{array}{l}\text { Housing } \\
\text { Authority of } \\
\text { Newport has } \\
\text { made my } \\
\text { situation worse }\end{array}$ & $0.0 \%(0)$ & $\begin{array}{l}5.6 \% \\
(3)\end{array}$ & $\begin{array}{l}5.6 \% \\
(3)\end{array}$ & $\begin{array}{c}\mathbf{5 0 . 0 \%} \\
(27)\end{array}$ & $\begin{array}{c}27.8 \% \\
(15)\end{array}$ & $\begin{array}{c}11.1 \% \\
(6)\end{array}$ & 4.13 & 54 \\
\hline $\begin{array}{l}\text { Brighton } \\
\text { Center's CSS } \\
\text { program has } \\
\text { made my } \\
\text { situation worse }\end{array}$ & $0.0 \%(0)$ & $\begin{array}{c}11.5 \% \\
(6)\end{array}$ & $\begin{array}{l}1.9 \% \\
(1)\end{array}$ & $\begin{array}{c}38.5 \% \\
(20)\end{array}$ & $\begin{array}{l}38.5 \% \\
(20)\end{array}$ & $\begin{array}{l}9.6 \% \\
(5)\end{array}$ & 4.15 & 52 \\
\hline $\begin{array}{l}\text { I have better job } \\
\text { opportunities } \\
\text { because of } \\
\text { Brighton } \\
\text { Center's CSS } \\
\text { program }\end{array}$ & $15.1 \%(8)$ & $\begin{array}{c}32.1 \% \\
(17)\end{array}$ & $\begin{array}{c}11.3 \% \\
(6)\end{array}$ & $7.5 \%(4)$ & $3.8 \%(2)$ & $\begin{array}{c}30.2 \% \\
(16)\end{array}$ & 2.32 & 53 \\
\hline $\begin{array}{l}\text { I have better job } \\
\text { opportunities } \\
\text { because of } \\
\text { Housing } \\
\text { Authority of } \\
\text { Newport }\end{array}$ & $1.9 \%(1)$ & $\begin{array}{c}26.4 \% \\
(14)\end{array}$ & $\begin{array}{c}13.2 \% \\
(7)\end{array}$ & $\begin{array}{c}18.9 \% \\
(10)\end{array}$ & $7.5 \%(4)$ & $\begin{array}{c}32.1 \% \\
(17)\end{array}$ & 3.06 & 53 \\
\hline
\end{tabular}




\begin{tabular}{|c|c|c|c|c|c|c|c|c|}
\hline & $\begin{array}{c}\text { Strongly } \\
\text { Agree }\end{array}$ & Agree & Neutral & Disagree & $\begin{array}{l}\text { Strongly } \\
\text { Disagree }\end{array}$ & N/A & $\begin{array}{c}\text { Rating } \\
\text { Average }\end{array}$ & $\begin{array}{c}\text { Response } \\
\text { Count }\end{array}$ \\
\hline $\begin{array}{l}\text { I have choices } \\
\text { for } \\
\text { transportation } \\
\text { (ex. bus, biking, } \\
\text { car pooling) in } \\
\text { my } \\
\text { neighborhood }\end{array}$ & $24.1 \%$ (13) & $\begin{array}{c}44.4 \% \\
(24)\end{array}$ & $\begin{array}{c}0.0 \% \\
(0)\end{array}$ & $\begin{array}{c}20.4 \% \\
(11)\end{array}$ & $\begin{array}{c}11.1 \% \\
(6)\end{array}$ & $\begin{array}{c}0.0 \% \\
(0)\end{array}$ & 2.50 & 54 \\
\hline $\begin{array}{l}\text { My family and I } \\
\text { use bicycles or } \\
\text { walk to and } \\
\text { from school or } \\
\text { work }\end{array}$ & $5.6 \%(3)$ & $\begin{array}{c}38.9 \% \\
(21)\end{array}$ & $\begin{array}{l}1.9 \% \\
(1)\end{array}$ & $\begin{array}{c}13.0 \% \\
(7)\end{array}$ & $\begin{array}{c}18.5 \% \\
(10)\end{array}$ & $\begin{array}{c}22.2 \% \\
(12)\end{array}$ & 3.00 & 54 \\
\hline $\begin{array}{l}\text { My } \\
\text { neighborhood is } \\
\text { accessible to } \\
\text { people who are } \\
\text { elderly or } \\
\text { disabled }\end{array}$ & $16.7 \%(9)$ & $\begin{array}{c}53.7 \% \\
(29)\end{array}$ & $\begin{array}{c}3.7 \% \\
(2)\end{array}$ & $9.3 \%(5)$ & $7.4 \%(4)$ & $\begin{array}{l}9.3 \% \\
(5)\end{array}$ & 2.31 & 54 \\
\hline $\begin{array}{l}\text { I have better } \\
\text { educational } \\
\text { opportunities } \\
\text { now because of } \\
\text { the Housing } \\
\text { Authority of } \\
\text { Newport }\end{array}$ & $5.6 \%(3)$ & $\begin{array}{c}35.2 \% \\
(19)\end{array}$ & $\begin{array}{c}14.8 \% \\
(8)\end{array}$ & $\begin{array}{c}16.7 \% \\
(9)\end{array}$ & $5.6 \%(3)$ & $\begin{array}{c}22.2 \% \\
(12)\end{array}$ & 2.76 & 54 \\
\hline $\begin{array}{l}\text { I have better } \\
\text { educational } \\
\text { opportunities } \\
\text { now because of } \\
\text { Brighton } \\
\text { Center's CSS }\end{array}$ & $25.9 \%(14)$ & $\begin{array}{c}\mathbf{3 7 . 0 \%} \\
\text { (20) }\end{array}$ & $\begin{array}{c}13.0 \% \\
(7)\end{array}$ & $5.6 \%(3)$ & $1.9 \%(1)$ & $\begin{array}{c}16.7 \% \\
(9)\end{array}$ & 2.04 & 54 \\
\hline $\begin{array}{l}\text { Brighton } \\
\text { Center's CSS is } \\
\text { doing a good job }\end{array}$ & $51.9 \%(28)$ & $\begin{array}{c}44.4 \% \\
(24)\end{array}$ & $\begin{array}{c}0.0 \% \\
(0)\end{array}$ & $0.0 \%(0)$ & $0.0 \%(0)$ & $\begin{array}{l}3.7 \% \\
(2)\end{array}$ & 1.46 & 54 \\
\hline $\begin{array}{l}\text { Housing } \\
\text { Authority of } \\
\text { Newport (HAN) } \\
\text { is doing a good } \\
\text { job }\end{array}$ & $25.9 \%(14)$ & $\begin{array}{c}48.1 \% \\
(26)\end{array}$ & $\begin{array}{c}13.0 \% \\
(7)\end{array}$ & $5.6 \%$ (3) & $3.7 \%(2)$ & $\begin{array}{c}3.7 \% \\
\text { (2) }\end{array}$ & 2.10 & 54 \\
\hline $\begin{array}{l}\text { My life is better } \\
\text { because of } \\
\text { Brighton Center } \\
\text { CSS. }\end{array}$ & $38.9 \%(21)$ & $\begin{array}{c}42.6 \% \\
(23)\end{array}$ & $\begin{array}{c}13.0 \% \\
(7)\end{array}$ & $1.9 \%(1)$ & $0.0 \%(0)$ & $\begin{array}{l}3.7 \% \\
\text { (2) }\end{array}$ & 1.77 & 54 \\
\hline $\begin{array}{l}\text { My life is better } \\
\text { because of the } \\
\text { Housing } \\
\text { Authority of } \\
\text { Newport }\end{array}$ & $20.4 \%(11)$ & $\begin{array}{c}44.4 \% \\
(24)\end{array}$ & $\begin{array}{c}16.7 \% \\
(9)\end{array}$ & $7.4 \%(4)$ & $3.7 \%(2)$ & $\begin{array}{l}7.4 \% \\
(4)\end{array}$ & 2.24 & 54 \\
\hline
\end{tabular}




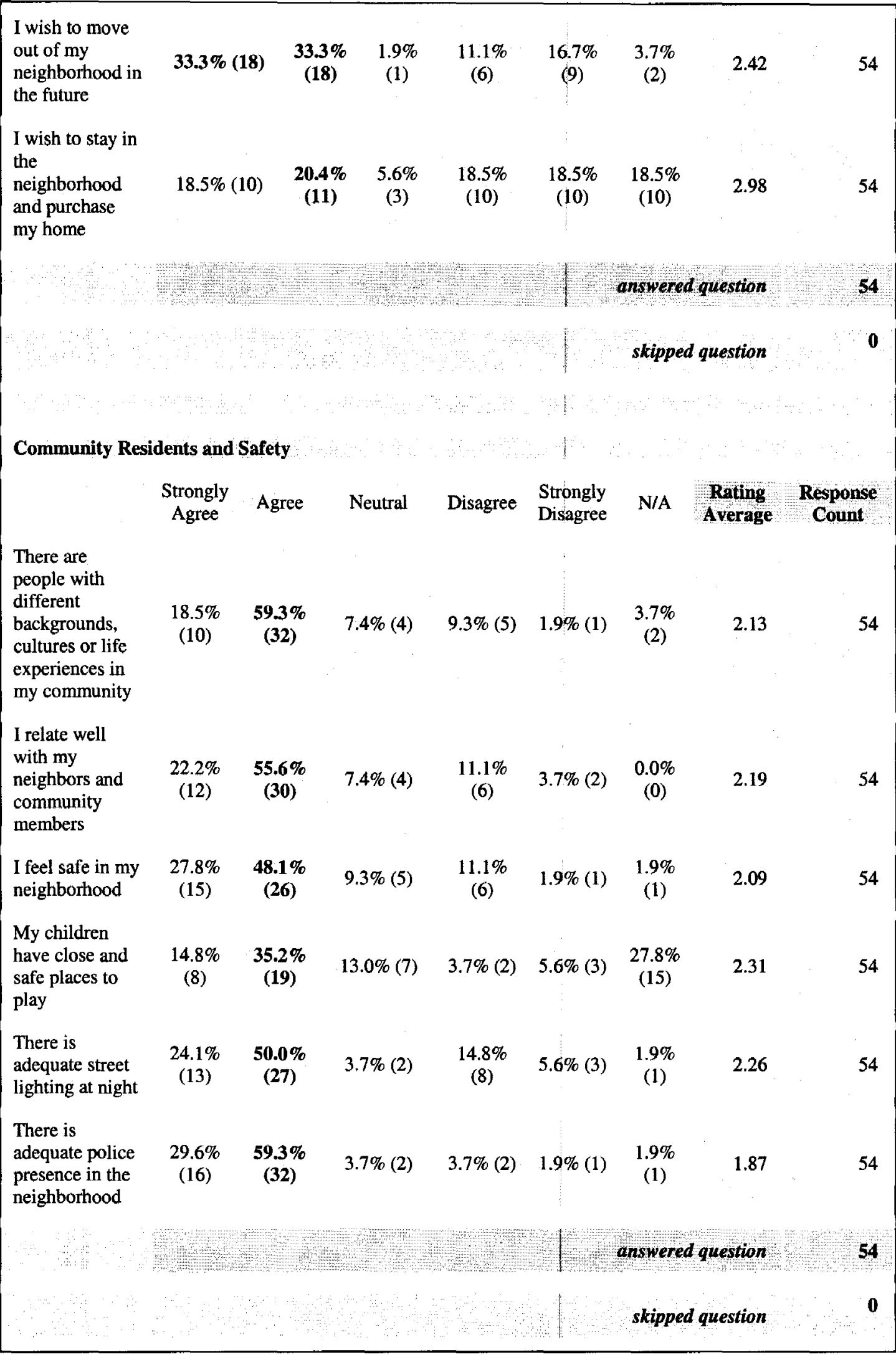




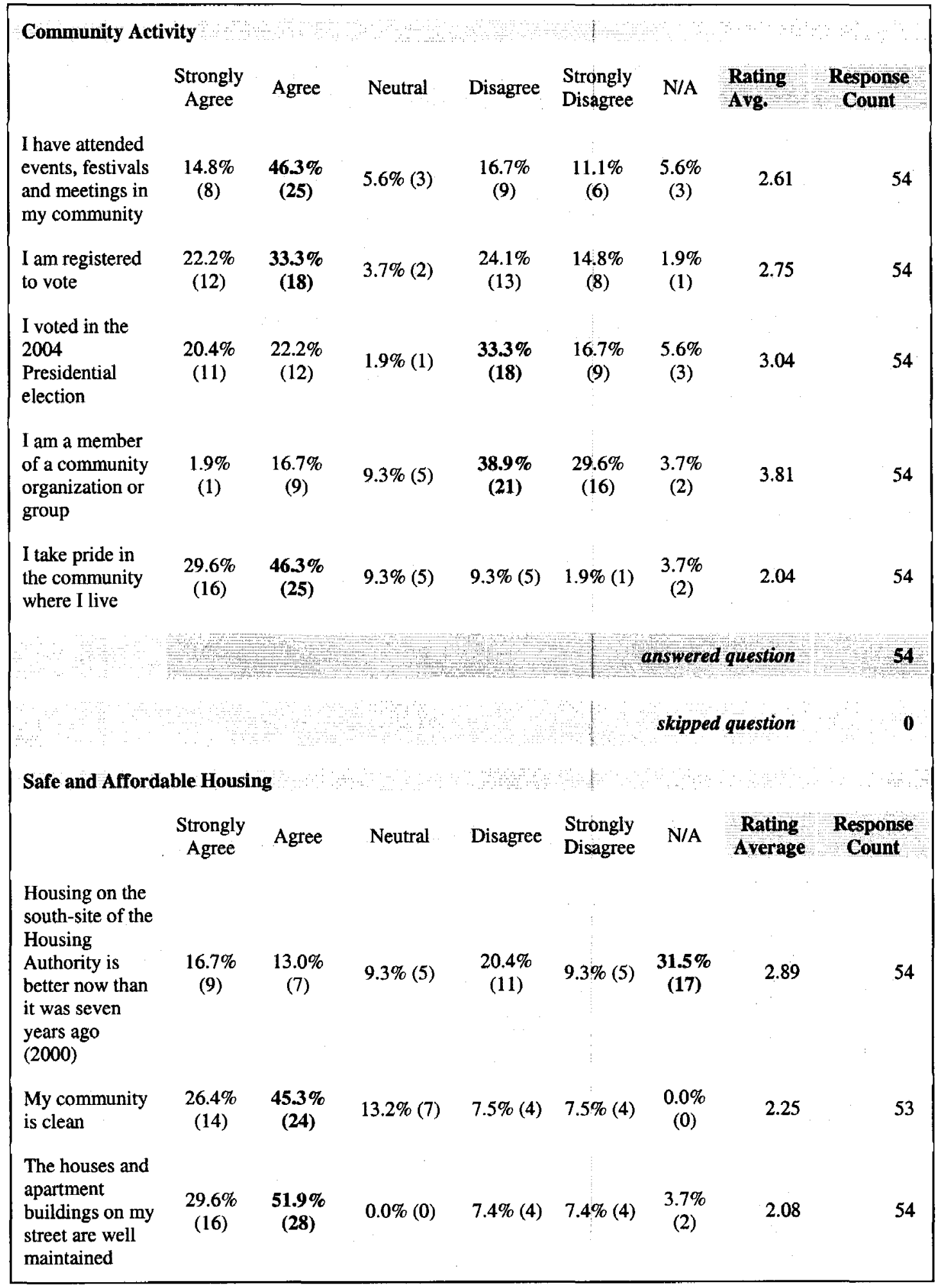




\begin{tabular}{|c|c|c|c|c|c|c|c|c|}
\hline & $\begin{array}{c}\text { Strongly } \\
\text { Agree }\end{array}$ & Agree & Neutral & Disagree & $\begin{array}{l}\text { Strongly } \\
\text { Disagree }\end{array}$ & N/A & $\begin{array}{c}\text { Rating } \\
\text { Average }\end{array}$ & $\begin{array}{c}\text { Response } \\
\text { Count }\end{array}$ \\
\hline $\begin{array}{l}\text { Graffiti has } \\
\text { gotten worse } \\
\text { since } 2000\end{array}$ & $\begin{array}{l}5.7 \% \\
(3)\end{array}$ & $\begin{array}{c}17.0 \% \\
(9)\end{array}$ & $13.2 \%(7)$ & $\begin{array}{c}30.2 \% \\
(16)\end{array}$ & $\begin{array}{c}24.5 \% \\
\text { (13) }\end{array}$ & $\begin{array}{l}9.4 \% \\
(5)\end{array}$ & 3.56 & 53 \\
\hline $\begin{array}{l}\text { There are more } \\
\text { drugs in my } \\
\text { neighborhood } \\
\text { than there was } \\
\text { in } 2000\end{array}$ & $\begin{array}{c}18.5 \% \\
(10)\end{array}$ & $\begin{array}{c}24.1 \% \\
(13)\end{array}$ & $7.4 \%(4)$ & $\begin{array}{l}22.2 \% \\
(12)\end{array}$ & $\begin{array}{c}13.0 \% \\
(7)\end{array}$ & $\begin{array}{c}14.8 \% \\
(8)\end{array}$ & 2.85 & 54 \\
\hline $\begin{array}{l}\text { There is more } \\
\text { gun violence in } \\
\text { my } \\
\text { neighborhood } \\
\text { than there was } \\
\text { in } 2000\end{array}$ & $\begin{array}{c}14.8 \% \\
(8)\end{array}$ & $\begin{array}{c}20.4 \% \\
(11)\end{array}$ & $5.6 \%(3)$ & $\begin{array}{c}29.6 \% \\
(10)\end{array}$ & $\begin{array}{c}20.4 \% \\
(11)\end{array}$ & $\begin{array}{c}9.3 \% \\
(5)\end{array}$ & 3.22 & 54 \\
\hline $\begin{array}{l}\text { There is more } \\
\text { safe and } \\
\text { affordable } \\
\text { subsidized } \\
\text { housing than } \\
\text { there was in } \\
2000\end{array}$ & $\begin{array}{c}13.0 \% \\
(7)\end{array}$ & $\begin{array}{c}42.6 \% \\
(23)\end{array}$ & $5.6 \%(3)$ & $\begin{array}{c}14.8 \% \\
(8)\end{array}$ & $\begin{array}{c}13.0 \% \\
(7)\end{array}$ & $\begin{array}{c}11.1 \% \\
(6)\end{array}$ & 2.69 & 54 \\
\hline $\begin{array}{l}\text { There is more } \\
\text { available }\end{array}$ & & & & & & & & \\
\hline $\begin{array}{l}\text { Section } 8 \\
\text { housing than } \\
\text { there was in } \\
2000\end{array}$ & $\begin{array}{c}13.0 \% \\
(7)\end{array}$ & $\begin{array}{c}\mathbf{5 0 . 0 \%} \\
(27)\end{array}$ & $0.0 \%(0)$ & $\begin{array}{c}13.0 \% \\
(7)\end{array}$ & $9.3 \%(5)$ & $\begin{array}{c}14.8 \% \\
(8)\end{array}$ & 2.48 & 54 \\
\hline $\begin{array}{l}\text { There is a } \\
\text { shorter Section }\end{array}$ & & & & & & & & \\
\hline $\begin{array}{l}8 \text { housing } \\
\text { waiting list than } \\
\text { there was in } \\
2000\end{array}$ & $\begin{array}{l}5.9 \% \\
\text { (3) }\end{array}$ & $\begin{array}{c}37.3 \% \\
(19)\end{array}$ & $3.9 \%(2)$ & $\begin{array}{l}19.6 \% \\
(10)\end{array}$ & $9.8 \%(5)$ & $\begin{array}{l}23.5 \% \\
(12)\end{array}$ & 2.87 & 51 \\
\hline $\begin{array}{l}\text { There are more } \\
\text { market-rate } \\
\text { housing } \\
\text { opportunities } \\
\text { than there was } \\
\text { in } 2000\end{array}$ & $\begin{array}{c}13.2 \% \\
(7)\end{array}$ & $\begin{array}{l}54.7 \% \\
(29)\end{array}$ & $3.8 \%(2)$ & $7.5 \%(4)$ & $0.0 \%(0)$ & $\begin{array}{l}20.8 \% \\
(11)\end{array}$ & 2.07 & 53 \\
\hline $\begin{array}{l}\text { I am more } \\
\text { comfortable } \\
\text { allowing my } \\
\text { kids to play } \\
\text { outside in the } \\
\text { neighborhood } \\
\text { than I was in } \\
2000\end{array}$ & $\begin{array}{l}20.4 \% \\
(11)\end{array}$ & $\begin{array}{c}31.5 \% \\
\text { (17) }\end{array}$ & $5.6 \%(3)$ & $7,4 \%(4)$ & $5.6 \%(3)$ & $\begin{array}{l}29.6 \% \\
(16)\end{array}$ & 2.24 & 54 \\
\hline & & & & & $11=$ & \multicolumn{2}{|c|}{ answered question } & 54 \\
\hline
\end{tabular}




\begin{tabular}{|c|c|c|c|c|c|c|c|c|}
\hline & $\begin{array}{l}\text { Strongly } \\
\text { Agree }\end{array}$ & Agree & Neutral & Disagree & $\begin{array}{l}\text { Strongly } \\
\text { Disagree }\end{array}$ & N/A & $\begin{array}{l}\text { Rating } \\
\text { Average }\end{array}$ & $\begin{array}{l}\text { Response } \\
\text { Count }\end{array}$ \\
\hline $\begin{array}{l}\text { Brighton } \\
\text { Center's CSS } \\
\text { has helped } \\
\text { improve my job } \\
\text { skills }\end{array}$ & $\begin{array}{c}25.9 \% \\
(14)\end{array}$ & $\begin{array}{c}37.0 \% \\
(20)\end{array}$ & $14.8 \%(8)$ & $1.9 \%(1)$ & $5.6 \%(3)$ & $\begin{array}{c}14.8 \% \\
(8)\end{array}$ & 2.11 & 54 \\
\hline $\begin{array}{l}\text { Brighton } \\
\text { Center's CSS } \\
\text { has helped } \\
\text { improve my } \\
\text { educational } \\
\text { skills }\end{array}$ & $\begin{array}{c}24.1 \% \\
\text { (13) }\end{array}$ & $\begin{array}{c}38.9 \% \\
\text { (21) }\end{array}$ & $14.8 \%(8)$ & $5.6 \%(3)$ & $5.6 \%(3)$ & $\begin{array}{c}11.1 \% \\
(6)\end{array}$ & 2.21 & 54 \\
\hline $\begin{array}{l}\text { Brighton } \\
\text { Center's CSS } \\
\text { has helped } \\
\text { connect me to } \\
\text { new } \\
\text { employment } \\
\text { opportunities }\end{array}$ & $\begin{array}{c}22.2 \% \\
(12)\end{array}$ & $\begin{array}{c}35.2 \% \\
\text { (19) }\end{array}$ & $7.4 \%(4)$ & $7.4 \%(4)$ & $1.9 \%(1)$ & $\begin{array}{c}25.9 \% \\
(14)\end{array}$ & 2.08 & 54 \\
\hline $\begin{array}{l}\text { Brighton } \\
\text { Center's CSS } \\
\text { has helped me } \\
\text { become more } \\
\text { employable by } \\
\text { working with } \\
\text { my resume and } \\
\text { interview skills }\end{array}$ & $\begin{array}{c}16.7 \% \\
(9)\end{array}$ & $\begin{array}{c}\mathbf{4 0 . 7 \%} \\
(22)\end{array}$ & $5.6 \%(3)$ & $3.7 \%(2)$ & $1.9 \%(1)$ & $\begin{array}{c}31.5 \% \\
(17)\end{array}$ & 2.03 & 54 \\
\hline $\begin{array}{l}\text { I have used } \\
\text { Brighton } \\
\text { Center's Bright } \\
\text { Days Child } \\
\text { Development } \\
\text { Center }\end{array}$ & $\begin{array}{c}13.0 \% \\
(7)\end{array}$ & $\begin{array}{c}20.4 \% \\
(11)\end{array}$ & $3.7 \%$ (2) & $\begin{array}{c}11.1 \% \\
(6)\end{array}$ & $7.4 \%(4)$ & $\begin{array}{c}44.4 \% \\
(24)\end{array}$ & 2.63 & 54 \\
\hline $\begin{array}{l}\text { Brighton } \\
\text { Center's CSS } \\
\text { has educated } \\
\text { me about } \\
\text { childcare } \\
\text { alternatives }\end{array}$ & $\begin{array}{c}17.0 \% \\
(9)\end{array}$ & $\begin{array}{c}26.4 \% \\
(14)\end{array}$ & $3.8 \%(2)$ & $3.8 \%(2)$ & $5.7 \%(3)$ & $\begin{array}{c}\mathbf{4 3 . 4 \%} \\
(23)\end{array}$ & 2.20 & 53 \\
\hline $\begin{array}{l}\text { Brighton } \\
\text { Center's CSS } \\
\text { has provided } \\
\text { programs for } \\
\text { my children }\end{array}$ & $\begin{array}{c}24.5 \% \\
(13)\end{array}$ & $\begin{array}{c}30.2 \% \\
(16)\end{array}$ & $3.8 \%(2)$ & $1.9 \%(1)$ & $5.7 \%(3)$ & $\begin{array}{c}\mathbf{3 4 . 0 \%} \\
(18)\end{array}$ & 2.00 & 53 \\
\hline
\end{tabular}




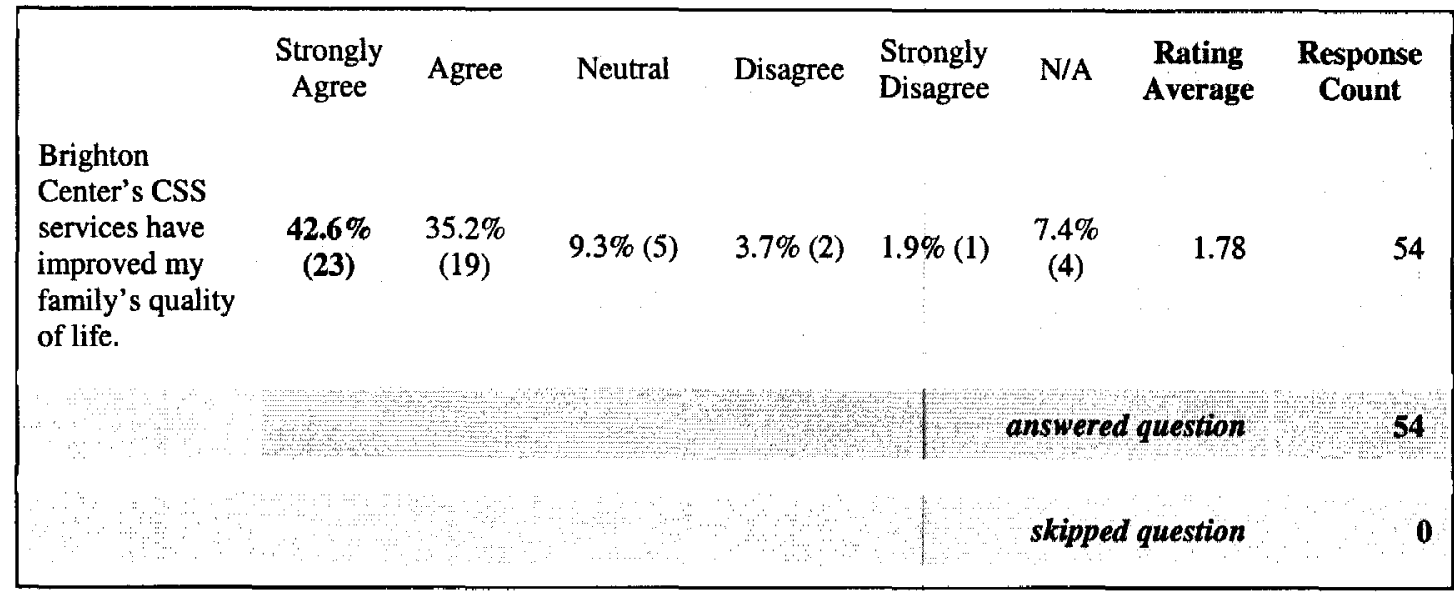




\begin{abstract}
APPENDIX C
ANALYSIS OF CRIME IN NEWPORT

Hanna Rosin (2007) in Atlantic Monthly magazine argued that HOPE VI caused a disbursement of low-income persons to other areas in cities in Kentucky and Tennessee, resulting in a spike in crime. Furthermore, Rosin (2007) argued that the increase in crime in American cities is the result of federal housing policy that pushes for integrating the poor into middle-class neighborhoods.

In certain aspects it is naïve to believe that crime would be affected by just one federal program. There are many factors that impact crime, so it is difficult to isolate exactly the forces at play. At the request of HUD, through the HOPE VI evaluation grant awarded to the University of Louisville Center for Sustainable Urban Neighborhoods (SUN), we were asked to collect data on crime in four police districts as a part of the agreement on our evaluation to compare the crime patterns in Newport before and after the introduction of the HOPE VI program.

Crime statistical data from 2000 to 2007 was collected from the Newport Police Department in cooperation with Captain Howard Niemeier, Administrative Services Coordinator for the Police Department. Crimes are recorded by the type of offense. From 2000 to 2007, 10 types of Part I criminal offenses (personal crime, property crime, and drug violations) occurred in the four police districts, Districts $2 \mathrm{~A}, 2 \mathrm{~B}, 2 \mathrm{C}$, and $4 \mathrm{~A}$.

These police districts are located just west of Monmouth Street in Newport, and are the districts of interest for this dissertation. The map on the next page shows the
\end{abstract}




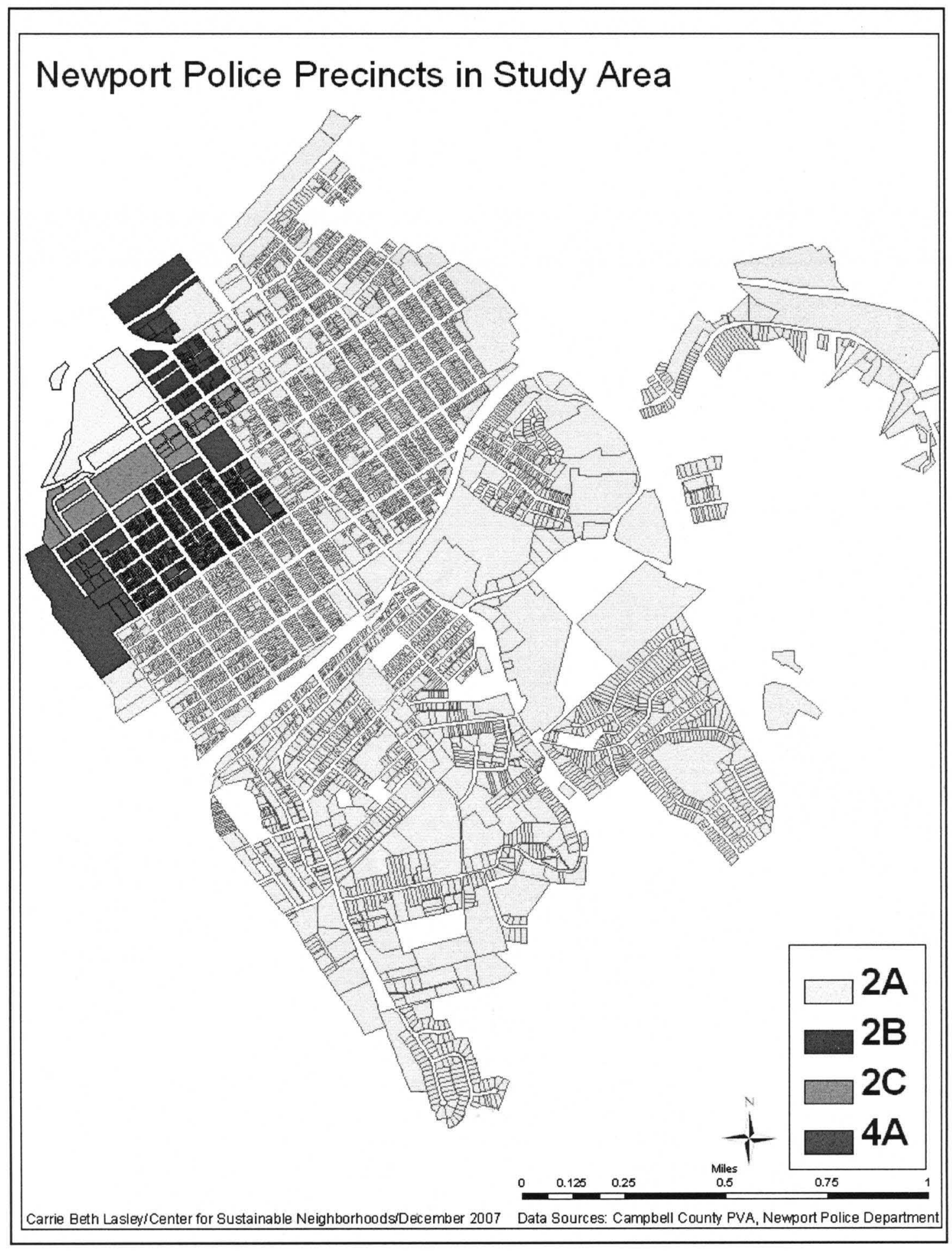

Figure C.1. Map of Newport police precincts 
relative location of these districts. These four districts are located in the west and northwestern portions of Newport. The old north-site housing units of the Housing Authority of Newport (HAN) are located in District 2A. The boundaries of District 2A are the Riverwalk to the north, the floodwall and Licking River to the west, Fifth Street to the south, and Columbia Street to the east. This district is primarily residential and once included the former north public housing site for the HAN. The remaining residents vacated the north-site on June 30,2006 . This site is currently a large vacant lot slated for the Ovation development discussed at the end of Chapter VI.

District $2 \mathrm{~B}$ is immediately to the east of District $2 \mathrm{~A}$, which includes the Levee, Campbell County Courthouse and the northern section of the Central Business District. District $2 \mathrm{C}$ and $4 \mathrm{~A}$ are immediately south of District $2 \mathrm{~A}$ and $2 \mathrm{~B}$. District $2 \mathrm{~B}$ and $2 \mathrm{C}$ are non-HOPE VI areas, while the current Newport public housing areas are located in both Districts 2C and 4A. District 4A includes much of the new HOPE VI developments such as Liberty Row (I), Liberty Housing (II) and the Brighton Center Family Development Center.

Personal crimes are crimes with victims, while property crime involves the theft or damage to property. Crime dropped 29 percent overall in the four districts. Personal crimes dropped 41 percent, property crime fell 37 percent, while drug violations grew by 20 percent, slightly lower than the national trend from 1996 to 2005 of a 16 percent increase, according to the Bureau of Justice Statistics. 
Changes in crime were not uniform across the four police districts. Precinct $2 \mathrm{~A}$, which is the old public housing site, and $4 \mathrm{~A}$, the district with the HOPE VI neighborhood experienced dramatic population shifts due to HOPE VI. It is not surprising to see a drop in District 2A. The chart on the next page shows the change in overall crime rate by precinct. The largest drop was in $2 \mathrm{~A}$ and $2 \mathrm{C}$, fueled by a significantly high decrease in shoplifting crimes.

All four districts experienced a decrease in crime. Districts $2 \mathrm{~B}$ and $4 \mathrm{~A}$ experienced the smallest decreases The amount of HOPE VI housing represents only a small portion of the total housing in that district. Precinct 2A (old public housing) showed an expected sharp decrease, because the Housing Authority of Newport's northsite residents have been displaced after the public housing was demolished in 2006 and is now mostly empty blocks. District $2 \mathrm{C}$, the non-HOPE VI area of the city on the south site public housing and parts of the Central Business District (CBD), also showed a higher than expected decrease in crime. This decrease is the result of fewer people living near this district and due to redevelopment on York and Monmouth Streets on the eastern edge of District $2 \mathrm{C}$.

\section{Crimes by Type}

Crimes were divided into three categories: personal crimes, property crimes and drug violations. Personal crimes include aggravated assault, simple assault, and robbery. Property crimes include burglary, shoplifting, vehicle theft, theft from a building, theft from a vehicle, and other theft. Drug violations were considered separately because there is no direct harm to other persons or property. The $\mathrm{Y}$-axis consists of the police district 
and the $\mathrm{x}$-axis in the percentage change in the particular crime. Total property crimes and personal crimes dropped in all precincts, but drug violations decreased in precincts $2 \mathrm{~A}$ and $2 \mathrm{~B}$, stayed the same in precinct $2 \mathrm{C}$, and increased in precinct $4 \mathrm{~A}$. Over all four districts, property crime dropped by 131 total offenses, personal crimes dropped by 118 offenses, and drug violations increased by 21 offenses.


Figure C.2. Crime change by type 2000-2007. (Source: Newport Police Department) 


\section{Personal Crime}

Figure C. 3 on the next page shows the drop in total crime among personal crimes, which includes robbery, aggravated assaults, and simple assaults. Aggravated assault dropped dramatically in every precinct. Given the population shift, a drop in all personal crimes was expected in $2 \mathrm{~A}$. However, simple assault and robbery increased in that district. Newport Police Officer Bill Johnson said that assault calls to the north public housing site were regular, rowdy and centered on Slaughter Lane and Bonner Court.

Since the north site has been removed, there has not been a similar spike in other areas, but the south site's Chestnut Street in $2 \mathrm{C}$ receives regular visits from police. The south site has experienced less criminal activity since the old north site had been demolished at the beginning of the HOPE VI program. In July 2007, Newport Police Officer Steve McElroy said there had not been any fights in the south site since January 2007. In previous years, police officers would receive regular calls to locations in the north and south sites, where groups of people, as many as ten would be engaged in a physical altercation. McElroy said: "We didn't get these 10-15-minute breaks to stand here and talk between calls before. On night shift, you were living down there, but that's not the case anymore. It's dead by 11 on a Friday night now. That's new." 


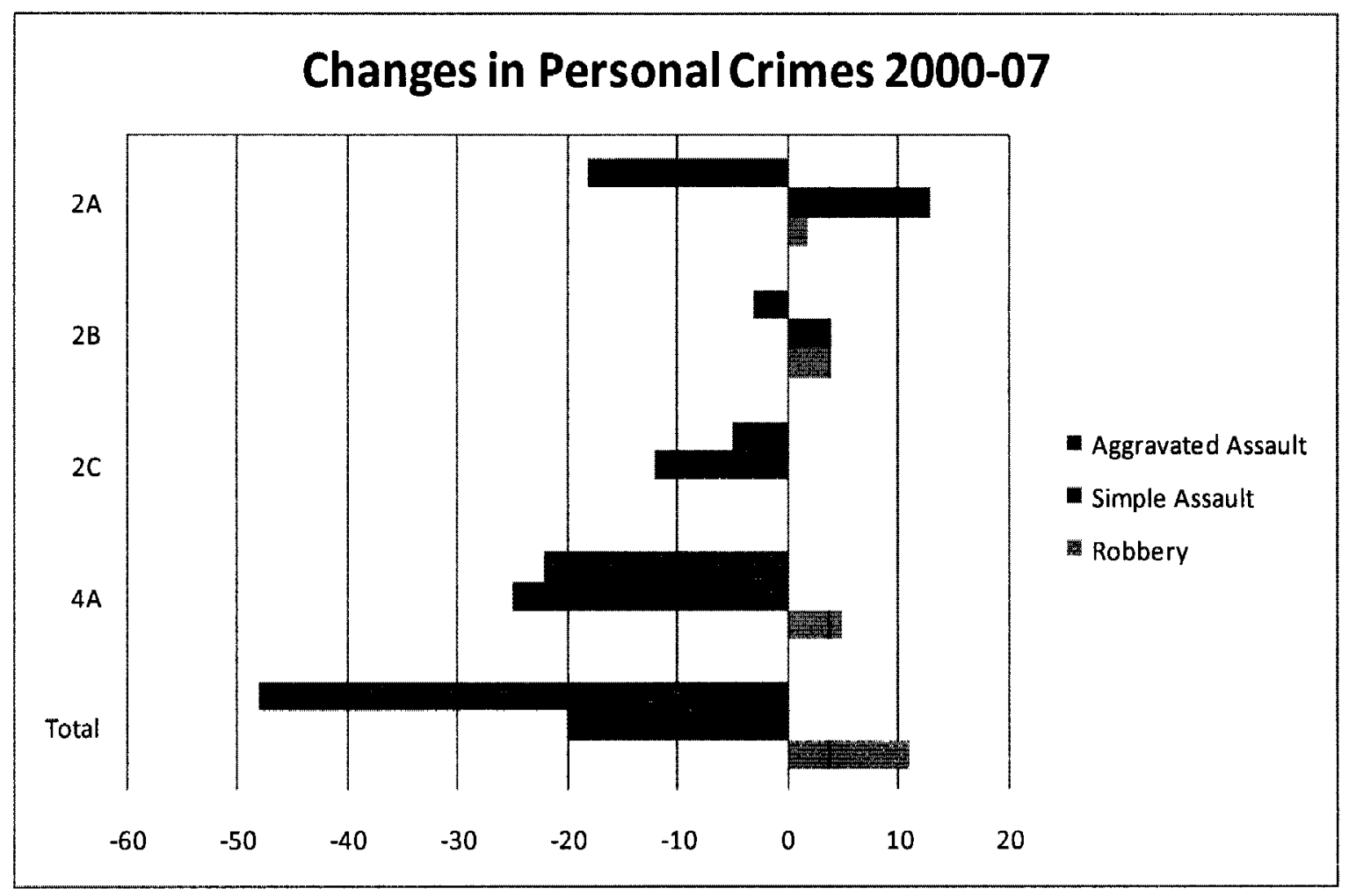

Figure C.3. Changes in personal crimes 2000-2007 (Source: Newport Police Department)

Robbery almost doubled, but much of the increase was experienced in District 4A. Johnson said juveniles stealing bicycles is the top problem with robbery in the area, which is relatively calm in recent years. Reports of robberies in District $2 \mathrm{~B}$ experienced an increase likely due to the Levee serving as a site of opportunity with tourists and easy access to city, county and state lines. However, the crime rate at the Levee has been relatively low. Crimes experienced in the tourist area have been juveniles stealing inexpensive jewelry during the day and intoxicated tourists during the night shift, according to Officer Johnson and Captain Niemeier. 


\section{Drug Violations}

Figure C.4 shows the change in total drug violations from 2000 to 2007 in the study area. Drug violations increased in two of the four precincts. The two most northern precincts, $2 \mathrm{~A}$ and $2 \mathrm{~B}$ showed modest drops, while $2 \mathrm{C}$ had virtually no change, and 4A showed an expected increase in these crimes.

The largest increase was in 4A with 21 more violations recorded in 2007 than in 2000. The increase of these crimes could be associated with the idle Thriftway

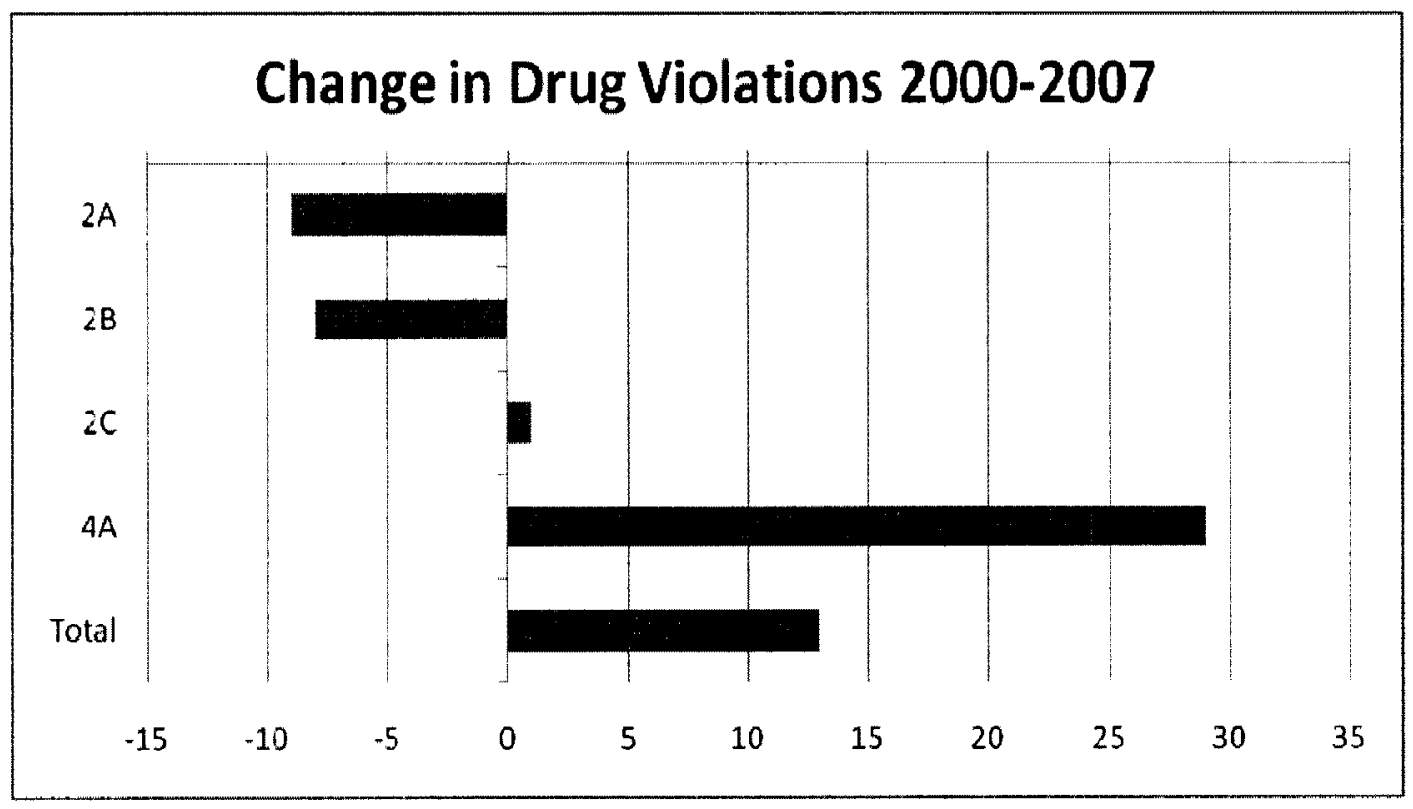

Figure C.4. Change in drug violations 2000-2007 (Source: Newport Police Department) 
Supermarket property and parking lot off of York Street, a venue conducive for drug trafficking, the location of the Campbell County Detention Center, and the West End Industrial area. Officer Bill Johnson identified the area as the block to purchase crack cocaine and marijuana in the city. The location of this heavy drug area may present a future problem for the sustainability and long-term economic health of the HOPE VI neighborhoods. Areas with open-air drug markets and readily available access to drugs may have an impact on residents getting a keeping a job, paying their mortgage, etc.

\section{Property Crime}

Vehicle theft showed a slight increase in all precincts, and the only property crime to show any significant increase across precincts. Theft from vehicles also increased in two precincts. This may be an indication of more targets of opportunity brought into the area from visitors to The Levee. Consistent decreases in theft from building, and the number of burglaries show promising trends. The large decrease in shoplifting is brought on by a dramatic decrease in precinct 2 C. Figure C.5 on the next page shows the total crime change among property crimes. 


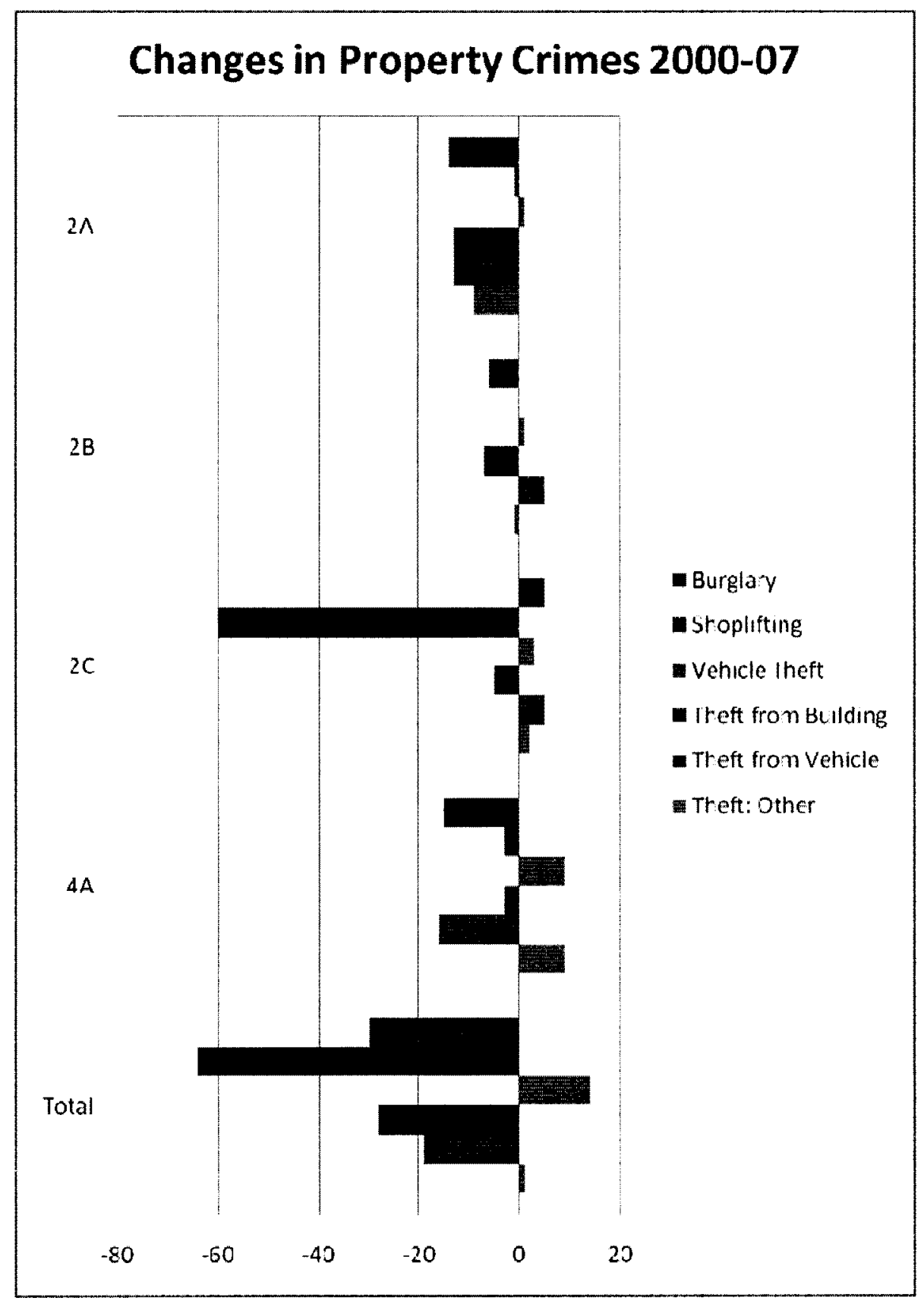

Figure C.5. Changes in property crimes 2000-2007 (Source: Newport Police Department) 
Table C.1.

Percent Change in Crime in Four Police Districts in Newport 2000-2007

\begin{tabular}{|l|l|l|l|}
\hline & $\begin{array}{l}\text { Number of } \\
\text { Offenses (2000) }\end{array}$ & $\begin{array}{l}\text { Number of } \\
\text { Offenses (2007) }\end{array}$ & Percent Change \\
\hline Robbery & 13 & 25 & $92 \%$ \\
\hline $\begin{array}{l}\text { Aggravated } \\
\text { Assault }\end{array}$ & 56 & 8 & $-86 \%$ \\
\hline Simple Assault & 220 & 138 & $-37 \%$ \\
\hline Burglary & 64 & 41 & $-36 \%$ \\
\hline Shoplifting & 74 & 6 & $-92 \%$ \\
\hline $\begin{array}{l}\text { Theft from } \\
\text { Building }\end{array}$ & 41 & 12 & $-71 \%$ \\
\hline $\begin{array}{l}\text { Theft from } \\
\text { Vehicle }\end{array}$ & 61 & 32 & $-48 \%$ \\
\hline Theft All Other & 98 & 99 & $1 \%$ \\
\hline Vehicle Theft & 17 & 34 & $100 \%$ \\
\hline Drug Violations & 103 & 124 & $-31 \%$ \\
\hline Total & 747 & 519 & \\
\hline
\end{tabular}

(Source: Newport Police Department) 


\section{Overall Analysis and Conclusion}

The crime data illustrated on Table C.1 on the previous page shows that the overall crime in all four districts in this study decreased by 31 percent from 2000 to 2007. After assessing the population movement and the concentration of the residents' location, crime reports were expected to shift from $2 \mathrm{~A}$, the former HAN north public housing site, into the other three districts because the residents from the north site were displaced in 2006. The development of the Ovation property on the former north site public housing area, crime should be expected to decrease crime further throughout the district

District 4A (HOPE VI development) experienced an approximately 10 percent decrease in overall crime, but areas of District 4A have seen increase in burglary, simple assault, aggravated assault, and vehicle theft, and drug violations.

Compared to the city of Cincinnati and the Cincinnati metropolitan area, crime has decreased at the local, regional, state and national level. Table C. 2 on the next page shows the comparison of crime according to the number of Part I offense (personal, property, and drug crimes). Crime data for the Cincinnati metropolitan area is comprised of the combined totals from Boone, Kenton, and Campbell Counties in Kentucky and Hamilton County in Ohio. As seen in this table, the decrease in crime among the four Newport police districts (2A, 2B, 2C, and $4 \mathrm{~A}$ ) in our study is the same as the overall decrease city wide. The crime is lowest in District $2 \mathrm{~A}$, the old public housing site, and

District $2 \mathrm{C}$, the south public housing site which encompasses the southern end of the Central Business District. 
Table C.2

Comparison of Crime in Covington, Newport, Cincinnati, Northern Kentucky and the

United States

\begin{tabular}{|l|r|r|r|}
\hline & $\begin{array}{l}\text { Total Crimes Part } \\
\text { I Offenses (2000) }\end{array}$ & $\begin{array}{l}\text { Total Crimes Part } \\
\text { I Offenses (2007) }\end{array}$ & Percent Change \\
\hline Covington & 3188 & 2642 & $-17 \%$ \\
\hline Newport & 1798 & 1235 & $-31 \%$ \\
\hline $\begin{array}{l}\text { Newport } \\
\text { Neighborhoods in } \\
\text { HOPE VI Study }\end{array}$ & & & \\
\hline 2A & & & $-57 \%$ \\
\hline 2B & 219 & 94 & $-5 \%$ \\
\hline 2C & 85 & 81 & $-58 \%$ \\
\hline *4A (HOPE VI \\
neighborhood)
\end{tabular}

Sources: Lt. Daniel Ogilvie, Cincinnati Police Department; Lt. Jane Poynter, Newport Police Department; Lisa Shoaf, Ohio Crime by County Statistics, Ohio Office of Criminal Justice Services (CJS); Crime in Kentucky 2000 and 2007 Crime Reports, Kentucky State Police, Frankfort, Kentucky

In 2007, Newport Police Officer Johnson and Newport Captain Niemeier viewed the HOPE VI housing developments as a boon to the community. Although crime has remained steady, Niemeier said (personal communication, July 24, 2007):

HOPE VI has had a minimally positive effect thus far. The north site housing that has been torn down has experienced a lower crime rate, but overall, it's been a minimal effect. Nonetheless, the HOPE VI program is definitely going to have an impact, but it's going to take some time to realize that. In the long term there's going to be a positive impact. One of the aspects of the program is moving them out of their neighborhood and teaching them to be good citizens. You're getting people to be good, productive people, to be homeowners. You're going to see a drop in crime. It just takes some time. 
In November 2008, Captain Niemeier changed course and concluded the HOPE VI has had a positive impact. The reduction in crime, according to Niemeier, "has made a difference through removing the older housing and people moving into newer, nicer affordable housing, and seeing people work and hold down jobs instead of doing nothing all day."(Howard Niemeier, personal communication, November 10, 2008).

In conclusion, we observe a correlation between the introduction of the HOPE VI program and the reduction in crime, but we do not have any evidence to measure or control for the exact effect of the intervening factors. Our findings are suggestive and speculative, but not definitive. The presence of HOPE VI correlating with the decrease in crime by 31 percent in Newport Districts $2 \mathrm{~A}, 2 \mathrm{~B}, 2 \mathrm{C}, 4 \mathrm{~A}$, compared with the rest of Newport, Covington, Cincinnati, and the greater Cincinnati metropolitan region shows that it may have had an impact, but it is not the direct cause of the reduction of crime. 


\section{APPENDIX D BUSINESS STARTUPS IN NEWPORT}

As we did with analyzing crime in four police districts in Newport, we were asked by HUD through the HOPE VI evaluation grant to collect data on business startups in downtown and the city of Newport before and after the introduction of the HOPE VI program. In trying to understand the relationship between HOPE VI and the economic revitalization of Newport, we must also see Newport within the context of the larger regional economic forces, so it is difficult to isolate and partial out the exact impacts.

Like the examination of crime in the neighborhoods, I want to understand the impact of business startups during the period before and after the introduction of HOPE VI program. During this study, I could not parcel out the impact of HOPE VI by simply looking at the growth of businesses throughout Newport. While this appendix will show that HOPE VI may have had an impact, through increases in businesses in downtown and throughout Newport, it is only suggestive and not causal.

In recent years, Cincinnati has attracted noteworthy educational, entertainment, and recreational amenities, such as the acclaimed Cincinnati Modern Art Museum, the National Underground Railroad Museum, and the state-of-the-art Great American Ballpark for the Cincinnati Reds and the adjacent Paul Brown Stadium for the Cincinnati Bengals. These projects were aimed at reinvigorating the residential life of downtown 
Cincinnati, but they failed to renew downtown residential neighborhoods using the new urbanist model due to an inefficient government and bureaucracy that was unsympathetic to the poor and minorities.

While the severity of the urban race riots in Cincinnati in 2001 might have been exaggerated by the intense media coverage, there is a perception that Cincinnati is in decline. Movies such as Traffic showed an unflattering picture of Cincinnati as being stark, dangerous and hopeless. In addition, the regrettable engineering decision to convert two-way streets to one-way streets, specifically on Vine Street in downtown Cincinnati, reduced commercial businesses by forty percent and has further contributed to the decline of downtown Cincinnati (Walker, Kulash, \& McHugh, 2007, F-2/5).

The power structure of Cincinnati, including the mayor, city council, and the University of Cincinnati, failed to address urban problems, put together effective partnerships and refused to embrace workable urban solutions. Cincinnati's loss has been Newport's gain. Cincinnati was known to lose many of the amenities that the Levee now has, including the Newport Aquarium. Also, the region's international airport located in Northern Kentucky became a huge economic loss to Cincinnati and a big economic gain for the region.

The leadership of the mayor of Newport played a significant role in the city's revitalization and produced a tremendous recovery from the city's checkered past. The charismatic mayor, Thomas Guidugli, who just left office after 16 years as mayor of Newport, aggressively pushed for and competed with Cincinnati for many of these amenities, which resulted in the development of Newport on the Levee and the Newport 
Aquarium. These amenities and local points of interest have attracted new businesses, tourists, and jobs, which has resulted in economic growth in downtown Newport.

Mayor Guidugli did not have a power elite pushing for a city of production over a place to live, but had the ability to allow Newport to think big, and had a keen sense of how cities grow or decline. The former mayor developed an aggressive agenda to develop Monmouth Street, a one-way thoroughfare through downtown Newport from Third Street to $12^{\text {th }}$ Street, in the heart of Newport's Central Business District (CBD) ending at the Levee, which includes a Graeter's Ice Cream on Fourth and Monmouth that relocated from downtown Cincinnati, and the expansion of the Mammoth Café on Monmouth Street near Fifth Street.

The mayor also pushed for the relocation of the Housing Authority of Newport's office at Ninth and Monmouth Streets, the relocation of the city of Newport building at Tenth and Monmouth and the Campbell County building at $11^{\text {th }}$ and Monmouth. All of these relocations totaled approximately $\$ 17$ million in development on Monmouth. The Marx-Cromer building, which was originally a tawdry sex club, then became too expensive for the city and HAN. The property was sold to a private developer, and has resulted in a $\$ 9$ million investment on Ninth and Monmouth Street.

Although much of the revitalization of the city was a result of Mayor Guidugli's leadership, there were other key players who made significant contributions to the economic development of Newport, such as Laura Long, Economic Development Director for the City in the 1990s and through the construction of the Levee in 2002 , James Parsons, the City Manager, Phil Ciafardini, the city's Finance Director, and Robert Yoder, Main Street Coordinator and City Planner in Newport, and also, a commitment by 
the Newport Police Department to receive accreditation in the next few years, according to Captain Howard Niemeier, Administrative Services Coordinator.

Historically, economic development in the region has been located in Cincinnati adjacent to Newport. Much of Newport's existence is tied to the economic fortunes of the Cincinnati/Northern Kentucky metropolitan area. Many Cincinnati residents have made the choice to move to Newport and surrounding cities in the metropolitan area. Newport and its amenities provide the convenience of living in downtown Cincinnati, but on a safer and smaller scale. Finally, preservation of historic housing also has been a key anchor in the renewal of Newport.

\section{Job Creation and Growth in Newport}

The labor force in Campbell County, Kentucky, and the city of Newport has grown over the past twenty years. In 1980, the workforce consisted of 36,472 workers. By 2000 , the workforce had increased by approximately 9,000 workers to 45,176 . In 2005 , the workforce was 46,425 . The unemployment rate for Campbell County has decreased over the past twenty years. In 1980, the unemployment rate was 6.7 percent, in 1990 the rate was 5.2 percent, and in 2000 the rate was 3.9 percent (Kentucky State Data

Center, 2007). In 2005, the unemployment rate increased to 5.6 percent; this was slightly higher than the national average unemployment rate (5.1 percent), but it was slightly lower than Kentucky's unemployment rate of 6.1 percent (Kentucky State Data Center, 2007). As of April 2009, the unemployment rate has risen to 8.5 percent and 9.2 percent in Kentucky. 
A major economic development project in Newport was the Levee, a multipurpose retail and entertainment complex built in 2002 on the riverfront that features shopping, specialty restaurants, comedy clubs, nightclubs, an AMC Multiplex Cinemas, and the Newport Aquarium. A new 250-room hotel is being built adjacent to the former IMAX Theater. The Levee caters to tourists visiting the entertainment, educational, and sports amenities in downtown Cincinnati and is within walking distance to Newport's downtown and historic district.

The Levee has generated economic renewal in a dying downtown area. In the first half of 2007, 23 percent of the new businesses in Newport were located on Levee Way in front of the Levee and the Newport Aquarium. Newport on the Levee received enormous subsidies to build the development. There is no real estate tax for the first 25 years, and there are rebates on the state sales tax. According to Michael Whitehead, Licensing Occupation Administrator for the city of Newport, the area where the Levee is located has received more revenue than before the Levee was built, but projects of this magnitude require subsidies from the government or these projects would never happen (Michael Whitehead, personal communication, June 25, 2007).

Although certain aspects of the Levee have been successful, such as the increase in restaurants and entertainment venues, the revenue generated from the Levee has not been as great as projected. The revenue generated by the Levee has barely made up for the revenue generated from StarKist Foods when their corporate offices relocated to Pittsburgh from Newport in 2000.

Despite the contributions of the Levee to downtown Newport, the Housing Authority of Newport's HOPE VI project has gradually rebuilt rundown residential and 
public housing properties. That redevelopment has been accompanied by the rise of property values throughout the city. This rejuvenation of the neighborhoods to the east and west of downtown Newport has helped reduce blight and crime while improving the pedestrian and business environment. A 24-hour city is generally correlated with a safer city. More people on the streets mean fewer opportunities for crime to occur, while more deserted streets mean more opportunities for crime (Kelling and Coles, 1996). That Newport is improving its neighborhoods while neighboring communities struggle is a selling point for new businesses who want a prime location within downtown Newport, which is conveniently within sight distance of downtown Cincinnati.

In addition, Monmouth Street has experienced a slow increase in pedestrian traffic and business and economic activity through downtown Newport as a result of the Levee. Pedestrian traffic down Monmouth and York Streets has enticed new small businesses and franchises into the area. Whitehead said the overflow effects from the Levee have been minimal, and consumers have not been as willing to cross Third Street and patronize Monmouth Street businesses as city officials hoped.

New condominiums and lofts have opened, and plans have been revealed for a new one billion dollar entertainment, retail, and residential complex called Ovation to be built over the next 10-15 years on the old public housing site. All of the development inspired a 2007 and 2008 summer soundtrack of construction and revitalization throughout the downtown and neighboring communities. 


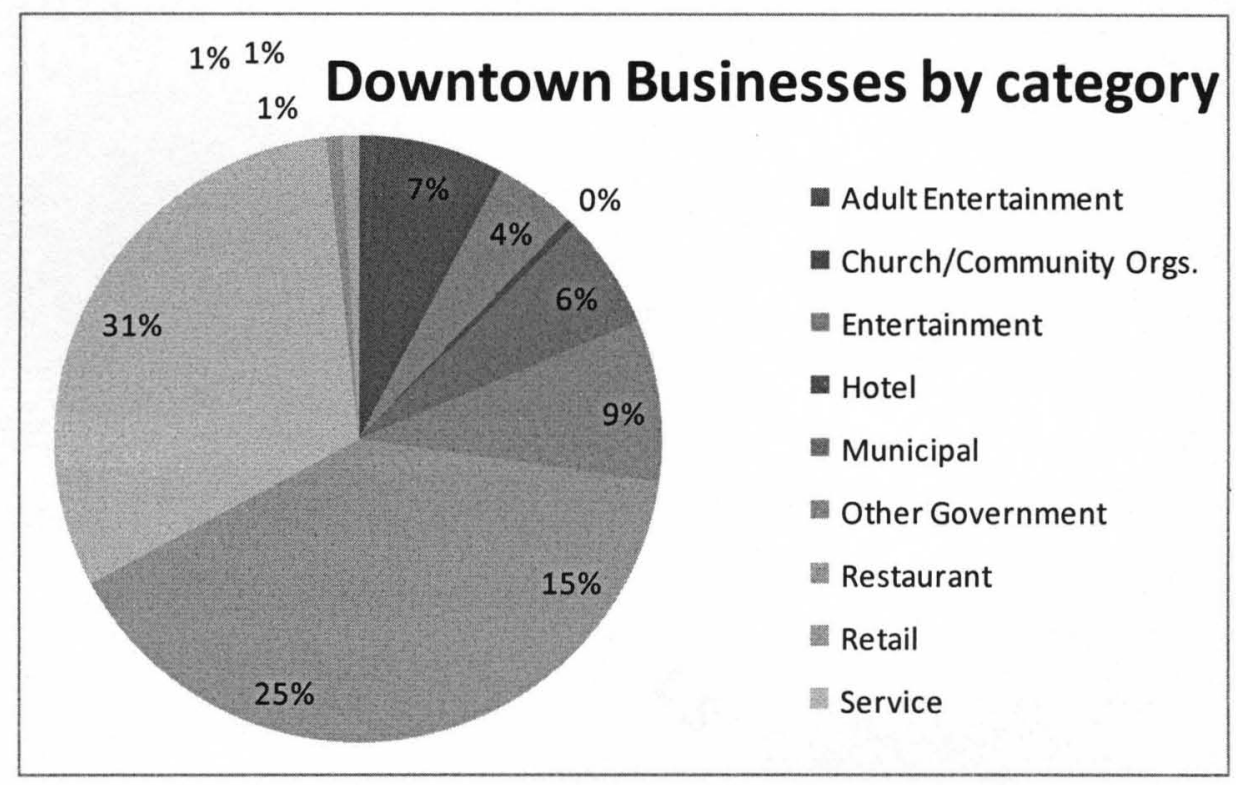

Figure D.1. New Downtown businesses by category and percent growth by category.

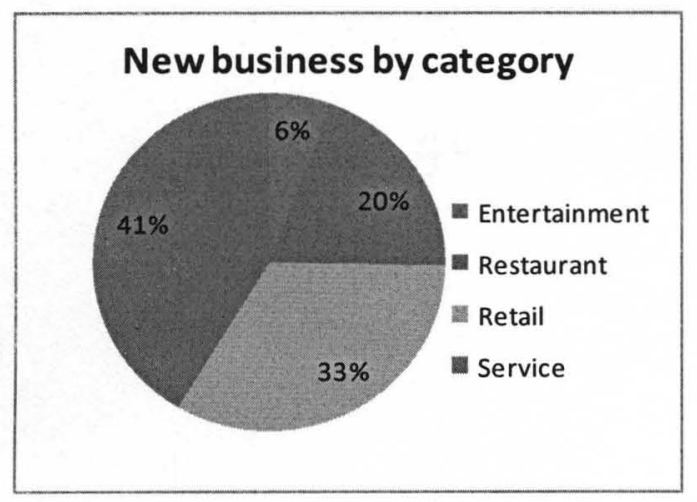

Figure D.2. New businesses by category and percent growth by category.

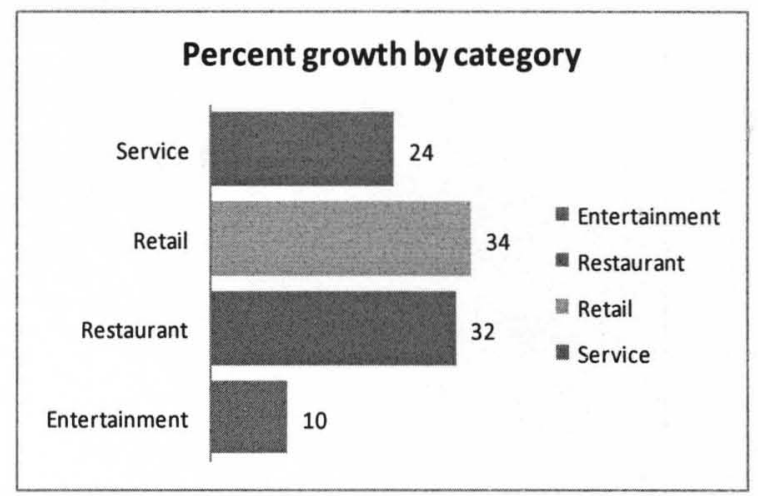

Figure D.3. Percent growth by category. 


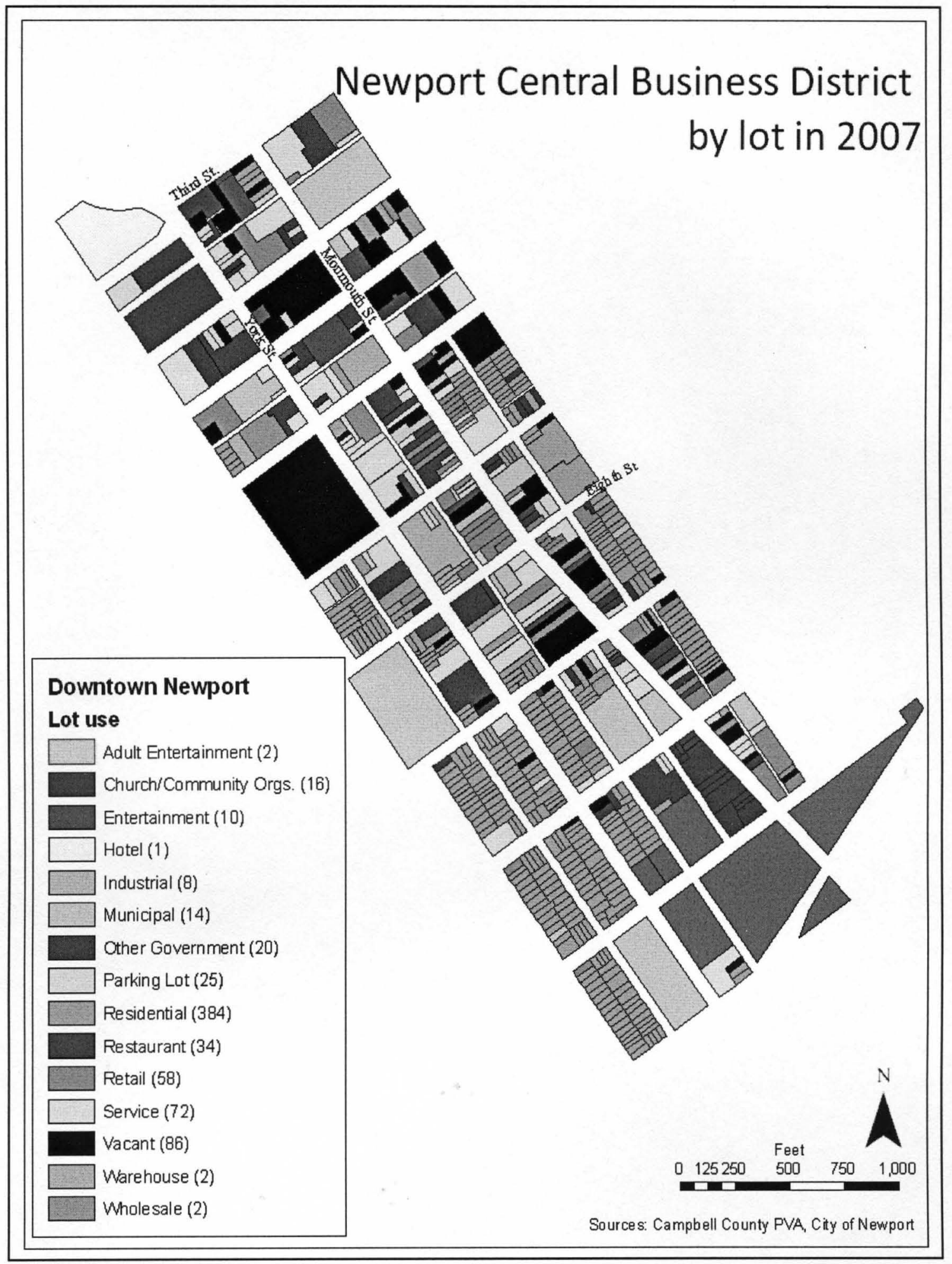

Figure D.4. Businesses by lot, 2007. 


\section{Businesses by Category}

Fifty percent (138 of 264) of businesses cross-referenced are still operating in downtown Newport. These businesses have been operating downtown for seven years or longer. After conducting informal interviews with approximately 30 business owners, a considerable proportion of these businesses have operated in downtown Newport for 10 , 20 , and in some instances, 50 years or longer.

The staying power of business in downtown Newport can be explained by several factors, such as the small specialized lot of businesses in downtown Newport and alternative modes of transportation, such as walking and public transportation, which provide options to residents and visitors for navigating through downtown Newport.

Also, some businesses in downtown are located on historic properties, which are well-maintained under the City of Newport's strict regulations. Downtown Newport has a long-standing "Main Street" image which includes locally owned and operated businesses which have evolved over time to offer a wide array of goods and services.

Figure D. 3 shows the breakdown of business by category in Downtown Newport in 2007, and Figure D.4 shows the same information geographically. The business categories include retail, industrial, restaurant, entertainment, adult entertainment, residential, parking lots, municipal, other government and community-based or church organization. Categorization was done by using PVA economic development and visual data. The map also shows vacant building lots, which represent both positives and negatives. Vacant buildings are locations for business opportunity and growth, but also attract crime and are often visually unappealing. 
The most successful businesses in downtown Newport are the printing companies because they provide a service for downtown Cincinnati businesses. The retail businesses are less successful because the lack of frontage parking and the decrease of customers who live and can walk to the business. Whitehead said the percentage of people below the poverty line can directly affect the kind of businesses located nearby. People will often shop at the Newport Shopping Center when they shop in Newport.

\section{Business Startups}

Businesses in Newport's downtown since HOPE VI are of higher quality than the 1980s, where Newport has gone from "vice" to "nice." A decade ago, Monmouth Street was a strip known for its adult entertainment and pawn shops. Many of these businesses

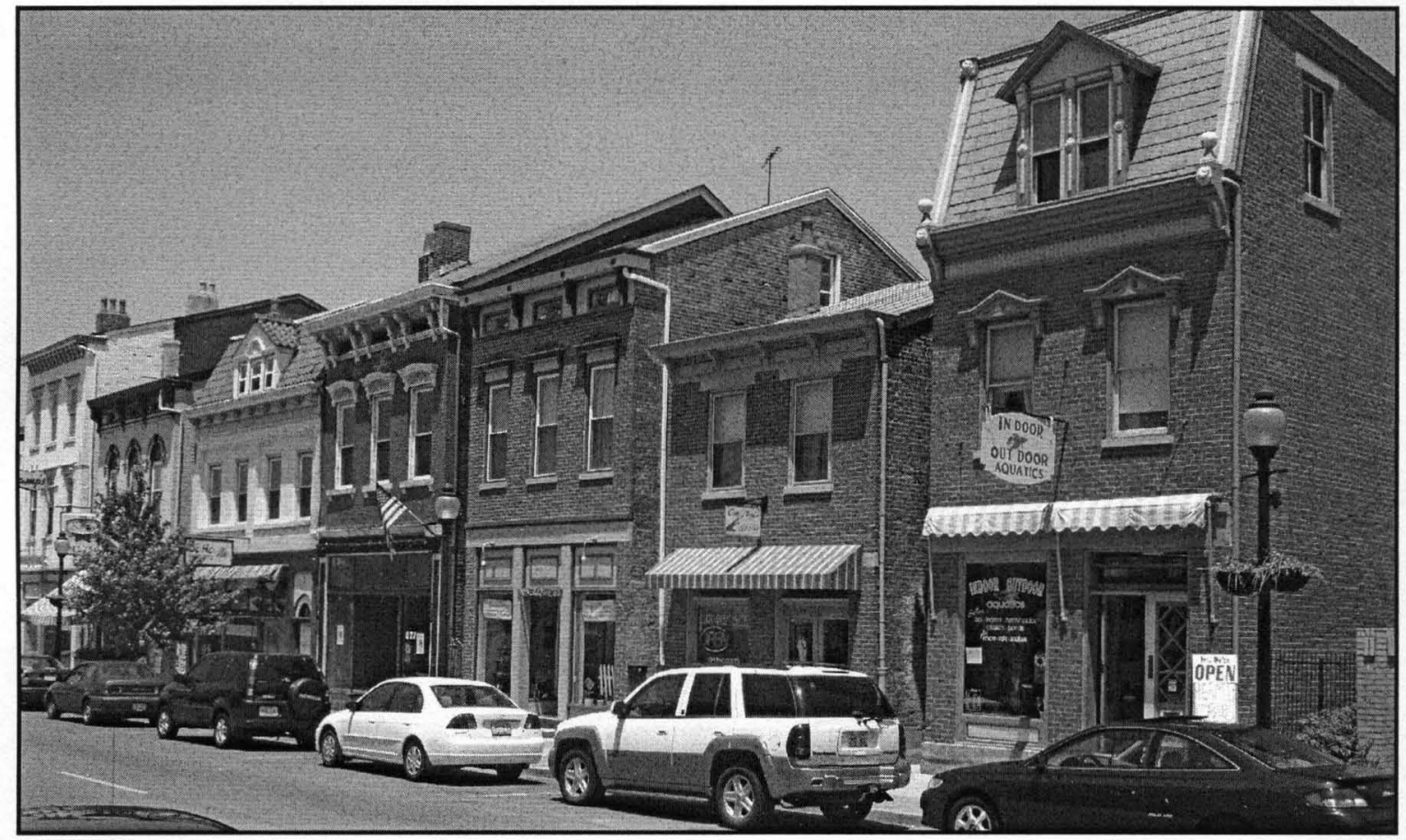

Figure D.5. Business and Streetscapes along Monmouth Street. 


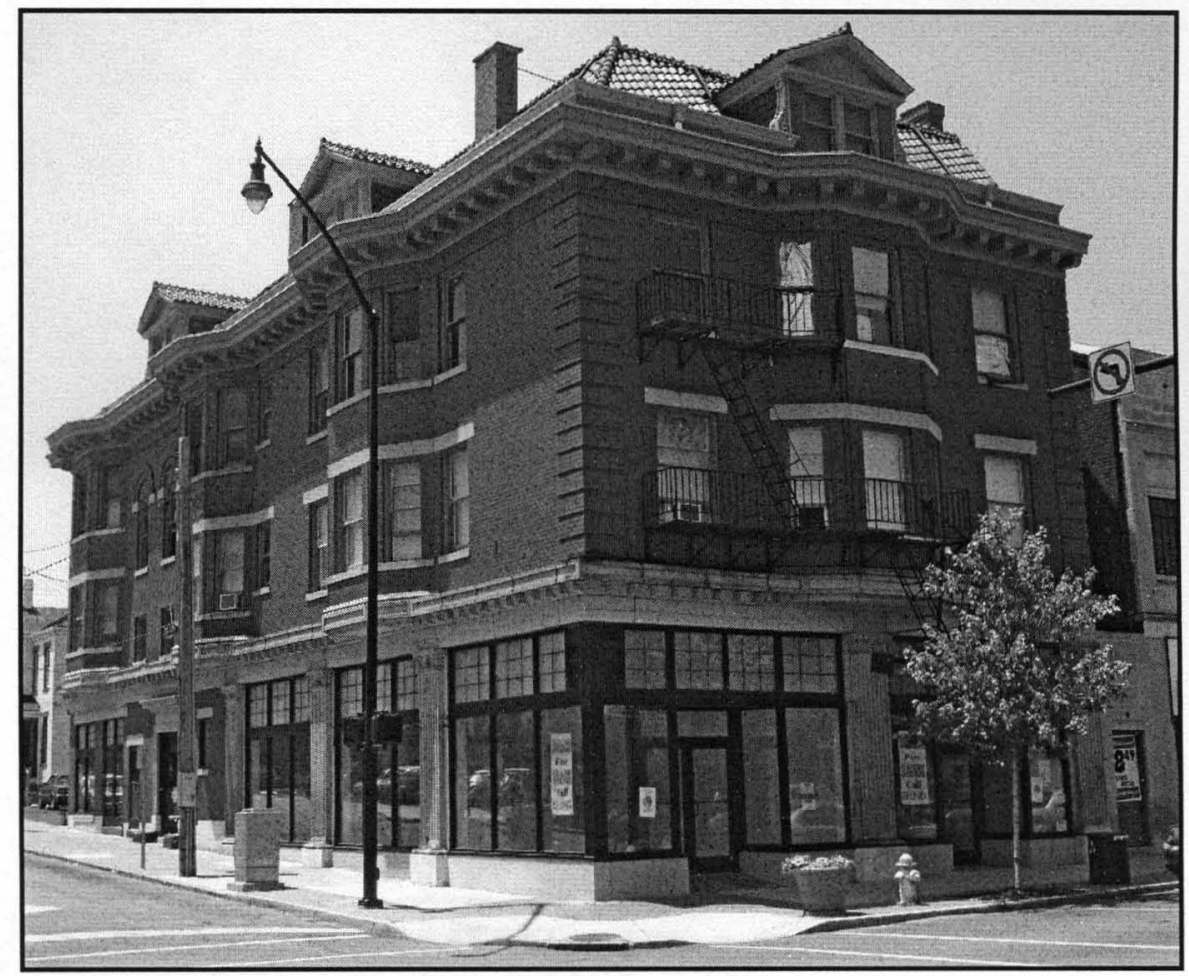

Figure D.6. Marx-Cromer Building at Ninth and Monmouth Street.

have left, and new family-friendly developments have moved into the area, including the retail and service industries, which represents the overwhelming majority of new businesses.

Steamboat Bagels and Graeter's Ice Cream have moved into restored historic buildings in downtown Newport. Vacant areas previously not being used by existing businesses are creating new business opportunities, such as a bar/restaurant adjacent to The Syndicate, which is now a separate new business. A yoga studio, bicycle shop, running store and community theater are some of the new businesses that have brought new stores and have found the location to be beneficial. Jobs in banks, auto shops, antique stores, and coffee shops are now a few blocks away from HOPE VI developments and public housing. Whitehead said the resources Newport has put into 
removing the adult entertainment establishments have laid the foundation for future development in Downtown and the Central Business District of Newport.

While these new job opportunities may or may not represent an increase in income, they do offer residents a chance to develop skills that transfer to other fields. The tamer atmosphere has brought renewed interest in downtown investment, including the development of upscale condominiums. In the past ten years, Newport's downtown changed from a neglected and abandoned area of businesses and nightclubs to an incubator for small-business.

Since 2001, business startups have been tracked using data collected from the city of Newport Economic Development Office. In the city of Newport, 66 new businesses were recorded in 2001; 85 new businesses were recorded in 2002 and 101 in 2007. On average, 76 new businesses were established annually from 2001 through 2006 , resulting in an 11 percent average annual increase.

To further examine how this growth affected downtown, additional analysis was needed. Data on startup businesses in Newport's CBD was collected from weekly and monthly economic reports from the city's Department of Finance and Administration. These reports list new business licenses awarded during the period. Business transfers were marked and excluded. A total of 84 businesses opened in Newport's downtown, excluding law firms throughout this period. 14 new storefronts opened in the Downtown "Renaissance" in 2007, and only four storefronts closed according to Bob Yoder, Main Street Coordinator for the city of Newport. With these new stores, Yoder claims "a significant visual jump in the sense of a lot of new businesses on the street" (Bob Yoder, personal communication, February 14, 2008). In 2007 , a $\$ 250,000$ grant helped to 
partially fund 12 building façade improvements for the downtown area to stimulate new business. Each eligible business recipient received a maximum of $\$ 20,000$, with a required minimum match of 50 percent. Many of the businesses spent far more than that on their improvements.

When businesses are established in a community the chances of success are extremely low in the first one or two years. After the second and third year of operation, the chances of success increase with each consecutive year of operation. A business's first-year chance of failure is 85 percent; the second year is 70 percent; third year is 62 percent; and in the fifth and sixth years the chances of failure are approximately 50 percent (Abrams, 2006). There are many reasons why businesses fail. A few of the reasons can include a poor business plan, a weak local economy, bad location and poor advertising techniques.

Figure D. 7 shows successful business startups in the CBD. The numbers in parentheses in the legend represents the number of business startups in that particular category. The majorities of new businesses were retail and were located toward the south and central areas of Monmouth Street. New service establishments were dispersed, and new restaurants mostly were located near the Levee or on Monmouth Street, such as JerZee's Pub and Grub, to capture some of the Levee pedestrian traffic.

Brian Lagory, owner of startup JerZee's, mentioned the Levee as a factor in his decision to locate there through receiving of the 12 downtown property owners to receive façade improvement grants in 2007. These grants were made possible by Newport's affiliation with the Kentucky Renaissance in Main, the state's version of the Main Street Program. It makes money available for matching grants for façade improvements and 


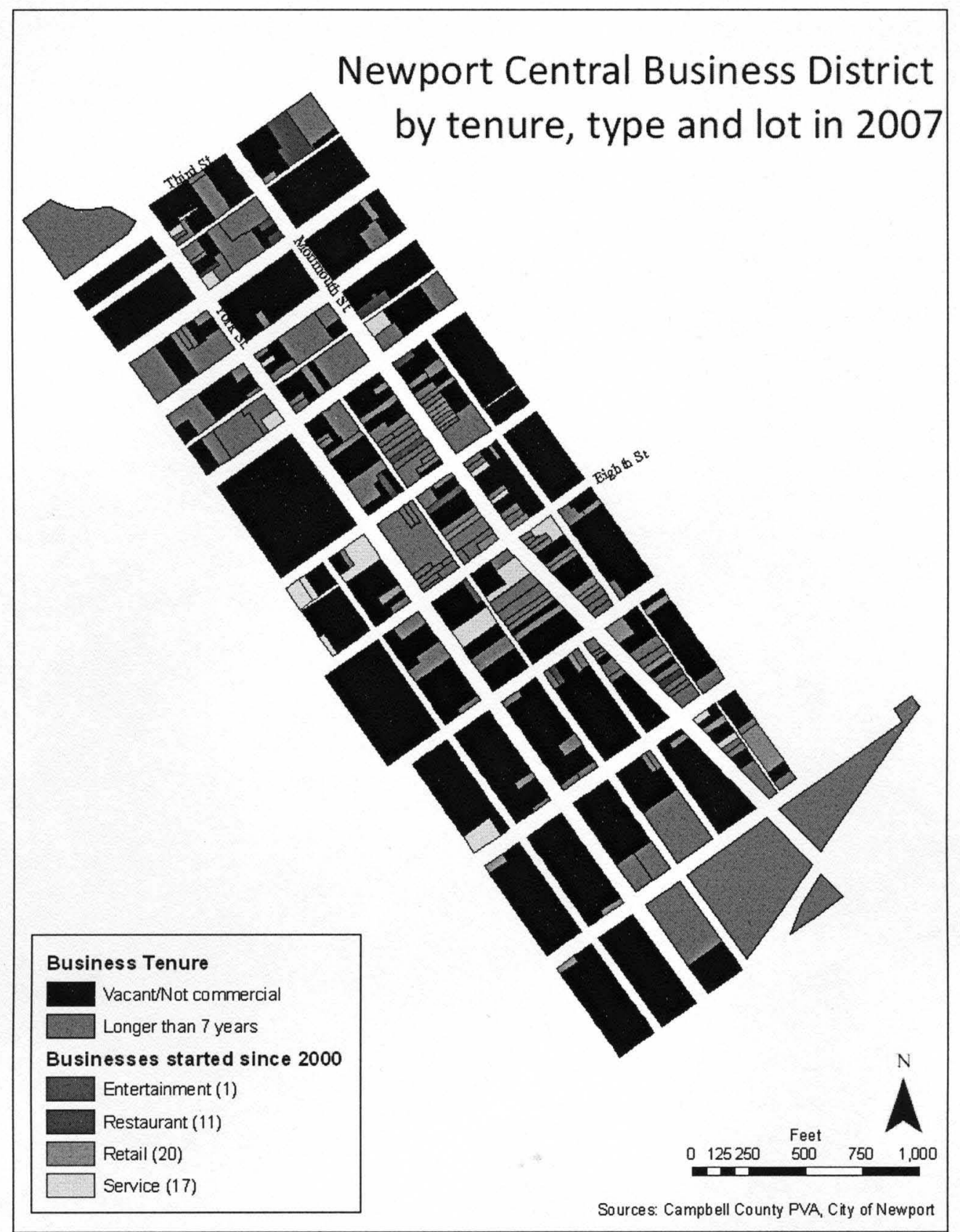

Figure D.7. Newport Central Business District by tenure, type, and lot, 2007. 


\section{Table D.1}

Main Street Façade Improvements in Downtown Newport

\begin{tabular}{|lr|}
\hline Business Name & Façade Grant \\
\hline Monmouth Street Lofts & $\$ 15,000.00$ \\
\hline Steamboat Bagels & $\$ 2,020.25$ \\
\hline 649 York-Vacant & $\$ 15,000.00$ \\
\hline JerZee's Pub \& Grub & $\$ 14,654.00$ \\
\hline Cricket/Beauty/Tax Prep & $\$ 15,000.00$ \\
\hline Jewel King & $\$ 2,874.00$ \\
\hline Footlighter's Inc. & $\$ 10,000.00$ \\
\hline Miller Imprints & $\$ 4,940.50$ \\
\hline Global Business Solutions & $\$ 15,000.00$ \\
\hline NKY Homes for Sale & $\$ 4,331.50$ \\
\hline Graeter's & $\$ 1,179.75$ \\
\hline Marx Cromer Lofts & $\$ 150,000.00$ \\
\hline & $\$ 250,000.00$ \\
\hline
\end{tabular}

(Source: Bob Yoder, Main Street Coordinator, City of Newport.) 
through various other methods of historic preservation, economic restructuring and marketing.

Newport also has qualified as a Preserve America community, a national endeavor aimed toward encouraging historic preservation. It is awarded to communities that have shown strengths in partnerships, civic commitment and economic efforts in preserving community heritage.

"The Newport Downtown Renaissance District has seen incredible growth in the last couple of years," said Main Street Director Bob Yoder (personal communication, February 14, 2008). "Buildings that have sat vacant for years have been rehabbed are being used for retail, restaurants, professional offices and market-rate housing. In 2007 alone we had 29 new businesses open in the district and saw the completion of 51 Market-Rate loft style apartments downtown." In the summer of 2007, the construction on Monmouth announced that those efforts were being realized.

By the beginning of 2008 , the Cincinnati media began to take notice of the restoring buildings in the burgeoning new business district, and promises of revival and declaring downtown Newport the "hub of the hip" (Fasig, 2008). Since last year, five companies have opted to move in or grow in downtown Newport, adding 20 new jobs in downtown Newport, including jobs in software technology and graphic design. On February 22, 2008, the Cincinnati Enquirer reported on the impact of restored buildings on attracting new business. Locally owned businesses sustain the local economy more effectively than big-box corporate chains.

The city of Newport has shown the initiative to pursue funding opportunities not just for housing, such as HOPE VI, but also to improve its downtown through opening 
new businesses. The result of these commitments is coming to fruition by offering new opportunities to public housing residents at a time when the city of Newport is prepared to meet the challenges of an improving and diversifying economic base. 


\section{CURRICULUM VITAE}

NAME: $\quad$ Matthew J. Hanka

ADDRESS: School of Urban and Public Affairs University of Louisville

Room 226

$426 \mathrm{~W}$. Bloom Street

Louisville, KY 40208

Phone: (502) 852-8258

mhanka@yahoo.com

Fax: (502) 852-4558

matt.hanka@louisville.edu
1430 S. Fourth Street, \#1

Louisville, KY 40208-2158

(Home): (502) 290-3889

(Mobile): (502) 296-7759

(Fax): (502) 582-0023

DOB: $\quad$ February 18,1980

EDUCATION

\& TRAINING: $\quad$ B.A., History and World Politics, minor in Religion The Catholic University of America, Washington, DC 2002

M.A., Political Science

Concentrations in International Relations and American Politics University of Louisville, Louisville, KY 2004

Ph.D., Urban and Public Affairs

Urban Policy and Administration Specialization

University of Louisville, Louisville, KY

2009

Graduate Research Assistant for Dr. Dewey Clayton, Dr. Sherri Wallace, Dr. Anne Caldwell, Department of Political Science University of Louisville

Spring 2004

Adjunct Lecturer/Part-Time Instructor Indiana University-Southeast, Jefferson Community and Technical College and University of Louisville 2004-2005 
Graduate Research Assistant for Dr. Leonard Bright

School of Urban and Public Affairs

University of Louisville

2005-2006

Graduate Research Assistant

Center for Sustainable Urban Neighborhoods (SUN)

University of Louisville

2006-2007

Graduate Research Associate

Center for Sustainable Urban Neighborhoods (SUN)

University of Louisville

2007-Present

Certificate, Future Faculty Program

College of Education and Human Development

University of Louisville

2008-2009

AWARDS: Graduate Research Assistantship, School of Urban and Public Affairs, University of Louisville

2005-2009

Graduate Dean's Citation, School of Interdisciplinary and Graduate Studies, University of Louisville 2009

Best Graduate Student Paper Award, American Society of Public Administration Metropolitan Louisville Chapter

October 24,2008

The Chenault/Delambre Young Person Award for Dedicated Service to Understanding and World Peace

Kentucky Division of the United Nations Association

October 27, 2007

Joel Goldstein Memorial Graduate Assistantship

Department of Political Science

University of Louisville

2004

Dean's List

The Catholic University of America

Fall 1999, 2000, 2001 
Honors in Social Sciences

University Honors Program

The Catholic University of America

May 2002

Membership in Pi Gamma Mu (Social Sciences), Phi Alpha Theta

(History), Pi Sigma Alpha (Politics and Government), and Theta Alpha

Kappa (Religion)

CUA

Spring 2002

Who's Who among Students in American Colleges and Universities

Award

CUA

2001-2002

Appointment, The Honorable Order of Kentucky Colonels

April 2002

Archbishop Keane Scholarship Recipient

Catholic University of America,

1998-2002

Co-authored grant to conduct a study on historic preservation in Kentucky, for Preservation Kentucky

May-October 2007 (\$20,000- private grant)

Worked on the end of 7 year HOPE VI evaluation grant from U.S.

Department of Housing and Urban Development (HUD) $(\$ 210,000)$

(2006-2008)

\section{PROFESSIONAL SOCIETIES:}

International Sociological Association-Research Committee 21 on Sociology of

Urban and Regional Development (ISA-RC21)

American Society of Public Administration (ASPA)

American Political Science Association (2003-2004 \& 2007-2009)

Kentucky Political Science Association (KPSA)

Urban Affairs Association (UAA)

United Nations Association of the USA (UNA-USA) 
Louisville Committee on Foreign Relations

Louisville Historical League

World Affairs Council of Kentucky and Southern Indiana

\section{PUBLICATIONS:}

\section{Referred Publications}

Gilderbloom, J., Hanka, M., \& Lasley, C. B. (2009, July). Amsterdam: The ideal city, policy and planning. Local Environment: The International Journal of Justice and Sustainability, 14 (6): $473-492$

Gilderbloom, J., Ye, L., Hanka, M., \& Usher, K. (2009, October). Inter-city rent differentials in the U.S. housing market 2000: Understanding rent variations as a sociological phenomenon. Journal of Urban Affairs (JUA), 31.

Hanka, M. (2008, January 5-8). The Impact of Sports Arenas as an Amenities Strategy on Economic Development in Louisville, Kentucky-Examining Benchmark Cities as Case Studies. Paper presented at the Sixth Annual Hawaii International Conference on Education Conference Proceedings. Honolulu, Hawaii.

Hanka, M., Kumaran, M., \& Gilderbloom, J. (2007, October 18-20). Estimating the Economic Effects, Consequences, and Impacts of President Clinton's Community Economic Empowerment Programs: An Analysis Using the Economic Impact Forecasting System. Paper presented at the Twenty-Eight Annual Southern Industrial Relations and Human Resources Conference Proceedings, Labor Management Center, University of Louisville, Louisville, Kentucky.

\section{Articles submitted and under review in Referred Journals}

Hanka, M., Gilderbloom, J., \& Ambrosius, J. Back to black ... and green? Contemporary housing dynamics in a medium sized U.S. city. Housing Policy Debate. Accepted for revise and resubmit

Gilderbloom, J., Hanka, M., \& Ambrosius, J. The impact of historic preservation on jobs, property values, and environmentalism. Journal of Urbanism. Accepted for revise and resubmit

Hanka, M. \& Gilderbloom, J. Newport HOPE VI: The impact of a federal program on a small river city. Public Administration Review (PAR). 
Gilderbloom, J., Hanka, M., \& Ambrosius, J. Without Bias? Government Policy that Creates Fair and Equitable Property Tax Assessments. Public Administration Review (PAR).

\section{Article being prepared for submission}

Gilderbloom, J., Hanka, M., \& Ambrosius, J. Capturing contemporary housing dynamics: Neighborhood value versus percent change

Hanka, M., Gilderbloom, John I., \& Ambrosius, J. Race, suburbs, and bad decisions: Predicting high foreclosures in neighborhoods.

\section{Non-Referred Publications}

Hanka, M., \& Gilderbloom, J. (2008, December 29). Newport, KY: America's Comeback City. The Courier-Journal.

Gilderbloom, J., Hanka, M., \& Lasley, C.B. (2008, September). Newport's HOPE VI project evaluation-Final report. Center for Sustainable Urban Neighborhoods, University of Louisville.

Gilderbloom, J. \& Hanka, M. (2008, May). Reinventing Louisville. Louisville Magazine.

Gilderbloom, J. \& Hanka, M. (2008, March 9). Why preservation matters. The Courier-Journal, Forum Section.

Hanka, M., \& Gilderbloom, J. (2008, February 1). Time to end one-way thinking. The Courier-Journal, A11.

Gilderbloom, J., House, E., \& Hanka, M. (2007, October 1). Historic preservation in Kentucky. Available from Preservation Kentucky, Inc.

Gilderbloom, J. \& Hanka, M. (2007, June 13). Louisville's new urbanism. The Courier-Journal, Forum Section, A11.

Gilderbloom, J. \& Hanka, M. (2007, May). The Green Real Estate Revolution. Available in the monthly newsletter of the Kentucky Real Estate Investors Association (KREIA).

Gilderbloom, J., \& Hanka, M. (2006, August). Newport's HOPE VI project evaluation, Volume IX. Center for Sustainable Urban Neighborhoods, University of Louisville. 
BOOKS:

\section{Book Chapter}

Roosa, S. A. \& Hanka, M. (2007, December). The Environment and Sustainable Development. The Sustainable Development Handbook. N.p.: Fairmont Press.

\section{Books and Journals Edited}

Gilderbloom, J., \& Hanka, M. (Guest Ed.). (2009). Sustain: A Journal of environmental and sustainability issues. N.p.: Kentucky Institute for the Environment and Sustainable Development (KIESD)

\section{INVITED PRESENTATIONS:}

Hanka, M., Gilderbloom, J., \& Ambrosius, J. (2009, March 6). Race, suburbs, and bad decisions: Predicting high foreclosures in neighborhoods. Paper presented to the $39^{\text {th }}$ Annual Meeting of the Urban Affairs Association (UAA), Chicago, $\amalg$.

Gilderbloom, J., Hanka, M., \& Ambrosius, J. (2009, March 6). Capturing contemporary housing dynamics: Neighborhood value versus percent change. Paper presented to the $39^{\text {th }}$ Annual Meeting of the Urban Affairs Association (UAA), Chicago, IL.

Ambrosius, J., Hanka, M., \& Gilderbloom, J. (2009, March 6). Different Data, Different Deal?: Comparing Three Sources of Neighborhood Housing Value. Paper presented to the $39^{\text {th }}$ Annual Meeting of the Urban Affairs Association (UAA), Chicago, IL.

Hanka, M. (2008, December 3). From vice to nice: A case study of the HOPE VI program in Newport, Kentucky. Paper presented to the Ph.D. Speaker Series, School of Urban and Public Affairs, University of Louisville, Louisville, KY.

Gilderbloom, J., Ambrosius, J., \& Hanka, M.. (2008, October 28-29). Slumburbia? Distance, foreclosures, and suburban housing values. Paper presented at the Rethinking Transportation for a Sustainable Future Conference, Galt House Hotel, Louisville, KY.

Hanka, M., Gilderbloom, J., \& Ambrosius, J. (2008, July 8-11). Back to black. . . and green? Contemporary housing dynamics in a medium sized U.S. city. Paper presented at the $4^{\text {th }}$ Joint Congress of American Collegiate Schools of Planning/Association of European Schools of Planning (ACSP/AESOP), Chicago, IL. 
Gilderbloom, J. \& Hanka, M. (2008, July 8-11). The impact of historic preservation on jobs, property values, and environmentalism. Paper presented at the $4^{\text {th }}$ Joint Congress of ACSP/AESOP, Chicago, IL.

Hanka, M. (2008, January 5-8). The impact of sports arenas as an amenities strategy on economic development in Louisville, Kentucky-Examining benchmark cities as case studies. Paper presented at the Sixth Annual Hawaii International Conference on Education, Waikiki Beach Marriott Resort, Honolulu, Hawaii.

Hanka, M. (2007, October 18-20). Estimating the economic effects, consequences, and impacts of President Clinton's community economic empowerment programs: An analysis using the economic impact forecasting system. Paper presented at the Twenty-Eight Annual Southern Industrial Relations and Human Resources Conference, Sponsored by the University of Louisville Labor Management Center, Seelbach Hotel, Louisville, Kentucky.

Gilderbloom, J., Hanka, M. \& Lasley, Carrie Beth. (2007, August 22-25). Amsterdam: The ideal city, policy and planning. Paper presented at the International conference on Urban Justice and Sustainability, International Sociological Association- Research Committee 21 on Sociology of Urban and Regional Development, University of British Columbia, Vancouver, British Columbia, Canada.

Gilderbloom, J., Ye, L., Hanka, M., \& Usher, K. (2007, August 22-25). Intercity rent prices in larger U.S. markets, 1990-2000: A sociological contribution. Paper presented at the International Conference on Urban Justice and Sustainability. International Sociological Association- Research Committee 21 on Sociology of Urban and Regional Development, University of British Columbia, Vancouver, British Columbia, Canada.

Hanka, M. (2007, July 24). Rotary and the United Nations. Speech to the East Louisville Sunrise Rotary Club, Louisville, KY.

Gilderbloom, J., \& Hanka, M. (2007, April 26). The green revolution in real estate. Paper presented at the monthly meeting of the Kentucky Real Estate Investors Association (KREIA). Louisville, KY.

Gilderbloom, J. \& Hanka, M. (2007, April 15). Russell and universitycommunity partnerships. Paper presented at the $99^{\text {th }}$ American Planning Association Annual Conference. Philadelphia, PA.

Gilderbloom, J., \& Hanka, M. (2007, April 11). The future of housing in Louisville: Creating affordable, accessible and attractive housing to make the world a nicer place. Paper presented at the Symposium on the $40^{\text {th }}$ Anniversary 
of the Fair Housing Ordinance in Louisville, KY. Sponsored by the Metropolitan Housing Coalition and Legal Aid Society, Louisville, KY.

Hanka, M. (2007, March 16). U.S. housing policy, HOPE VI, and university community partnerships. Paper presented to the Faculty of Architecture and Planning Department, University of Delft, The Netherlands.

Hanka, M., \& Gilderbloom, J. (2006, October 26-28). HOPE VI-Discussion on problems and prospects. Paper presented at the Twenty-Seventh Annual Southern Industrial Relations and Human Resources Conference, Sponsored by the University of Louisville Labor Management Center, Seelbach Hotel, Louisville, Kentucky.

Hanka, M. (2004, November 18). Rotaract and International Service Learning. Keynote speech presented to The Rotary Club of Louisville, Louisville, KY.

Hanka, M. (2004, November 10). The U.S. Electoral College. Presentation to the Fern Creek Rotary Club. Louisville, KY. 